PACIFIC LINGUISTICS

Series D - No. 12

\title{
CONVERSATIONAL NEW GUINEA PIDGIN
}

by

T.E. Dutton

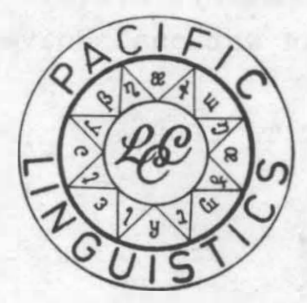

Department of Linguistics

Research School of Pacific Studies

THE AUSTRALIAN NATIONAL UNIVERSITY 
PACIFIC LINGUISTICS is published by the Linguistic Circle of Canberra and consists of four series:

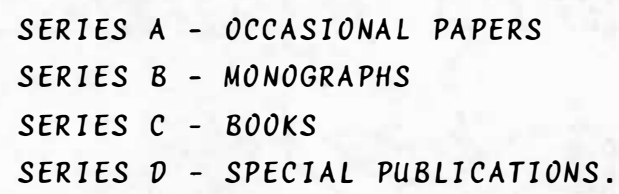

EDITOR: S.A. Wurm. ASSOCIATE EDITORS: D.C. Laycock, C.L. Voorhoeve.

ALL CORRESPONDENCE concerning PACIFIC LINGUISTICS, including orders and subscriptions, should be addressed to:

The Secretary,

PACIFIC LINGUISTICS,

Department of Linguistics,

School of Pacific Studies,

The Australian National University,

Box 4, P.O.,

Canberra, A.C.T. 2600.

Australia.

TAPES to accompany this volume should be ordered from

Mr J. Dillon,

Director,

Language Laboratory, S.G.S.,

The Australian National University,

Box 4, P.O.,

Canberra, A.C.T. 2600.

Australia.

Prices: $8 \times$ Cassettes $\$ 35.00$

$8 \times 7 "$ Reels $\$ 43.00$.

Copyright (C) T.E. Dutton.

First published 1973.

The editors are indebted to the Australian National University for help in the production of this series.

This publication was made possible by an initial grant from the Hunter Douglas Fund.

National Library of Australia Card number and ISBN 0858830965 


\section{PREFACE}

New Guinea Pidgin is one of the two major lingue franche of Papua New Guinea. It has at present over one million speakers and their number is increasing rapidly, as is that of those who speak Pidgin as their first language, and who may now number several thousands. Throughout Papua New Guinea, speakers of Pidgin can now be encountered even in areas which were until a few years ago the exclusive realm of Hirl Motu, the other major lingua franca of the area. The language has been gaining tremendously in importance and prestige during the last few years. It always has been, and continues to be, the major means of intercommunication amongst Papuans and New Guineans who have no other language in common. Even amongst speakers of the same local language it is frequently used for prestige reasons. Although never an official language it has been used for a long time throughout Papua New Guinea for administrative purposes, but its importance has been greatly enhanced through its becoming the language of discussion in the majority of Local Government Councils and the House of Assembly. A knowledge of it is now envisaged as a prerequisite for Papua New Guinea Citizenship and it is destined to play a much more important role in education in this country on the primary level, at least more than has hitherto been the case. It seems that New Guinea Pidgin is heading rapidly towards becoming the national language of Papua New Guinea and it is possible that it may, in a standardized form, eventually even become the standard--at least written--lingua franca of the South-Western Pacific whose present unstandardized lingue franche are closely related to New Guinea Pidgin with partial mutual intelligibility existing between them and the latter.

New Guinea Pidgin is a pidgin language whose vocabulary is derived from, but by no means identical with, English to the extent of $75-80 \%$, with 15-20\% based on indigenous languages mainly Tolai of northern New Britain, and $5 \%$ on other languages, predominantly German. Its structure is un-English and is patterned on that of the Austronesian languages of the South-Western Pacific.

New Guinea Pidgin is a direct descendant of Bichelamar, the 19th century English-based lingua franca of the South Pacific which, in a modern form, is still in use as the lingua franca of the New Hebrides 
even today. Bichelamar itself is assumed to be a descendant of English-based Chinese Pidgin which was introduced into the Pacific by traders and sallors who were collecting sandalwood and a specles of sea-cucumber called beche-de-mer in French, which they sold in China where 1t was a highly prized special ingredient of soup. In contact situations between these traders and sallors, and South Sea Islanders, the Chinese Pidgin employed by the former was modified to give rise to Bichelamar.

In 1847 the use of indentured labour from the South-Western Pacific began on the sugar-cane plantations of North Queensland to continue unt1l 1902 when 1t was outlawed. During these years a large number of islanders from many different language areas were brought to North Queensland. The only language which many of the 1slanders who were forced to live in close contact with each other in large numbers had in common was Bichelamar, which led to 1 ts extensive use and the rapid spread of 1 ts knowledge amongst them. It also resulted in a great enrichment of the language in view of its general use as a means of expression and intercommunication in situations and pursults belonging completely to the indigenous cultural sphere.

The 1slanders brought this enriched pidgin language back with them when they returned to Melanesia and their elevated soclal standing as returned labourers strengthened the prest1ge of the language in the islands. This led to the rapld spread of the language as an interindigene lingua franca. As such it was used as an unofficlal administrative language by the then German Administration in the form in which it was spoken in the Rabaul area of New Britain towards the end of the 19th century and spread rapidly through those parts of German New Guinea which were under administrative control. After the Australian administration had taken over after World War I, the spread of this language to which the word New Guinea Pidgin could now well be applied accelerated without much effort or teaching on the part of the administration by the Europeans in general and basically as a result of 1ts functioning as arı inter-indigene lingua franca.

The present course by T. E. Dutton, Conversational New Guinea Pidgin, constitutes a major step forward in making avallable to persons interested in acquiring; a good working knowledge of New Guinea Pldgir a serles of well balanced, graded lessons providing extensive materials for study and practical language application. Moreover, a specific advantage of this course is that it gives the student a firm basis from which to handle dialectal variation throughout Papua New Guinea. Pidgin, in its spoken form manifests itself in many dialectal varlations with the dialects in part regional, in part socially 
determined, thereby largely reflecting the greater or lesser contact of the speakers with European speakers of Pidgin and mirroring some of its typical idiosyncrasies on the phonological, lexical, grammatical and discourse levels. Varled degrees of influence from English and attempts by Pidgin speakers to include English elements in their Pidgin, also leads to multifarious forms of spoken Pidgin. All these factors make themselves felt, of course, when Pidgin speakers use the language for the purpose of written expression.

It is clear that standardization of Pidgin, which is badly needed in the light of the increasing importance of the language as referred to above, will have to start with its written form. One particular standard orthography is already avallable and has been used in Mihalic's new dictionary (The Jacaranda Dictionary and Grammar of Melanesian Pidgin), the Pidgin New Testament, and in the publications issued by Kristen Press, Madang, but its universal--or even general-acceptance is still a matter for the future, especially in administrative and Government circles. A certain amount of standardization pressure affecting Pidgin vocabulary and grammar is exercised by the abovementioned publications, but their influence falls far short of that which they may have on orthography, and individual usage is still widespread.

At this point a question of pedagogical philosophy arises: Should standardization of a language be concerned exclusively with accepting the most commonly encountered forms of speech and disregard and relegate to sub-standard usage, less frequently used forms which for reasons of clarity of expression, avoldance of ambiguity, and similar reasons may well be preferrable to the more frequently found forms? Or should it be concerned with the less common forms which for reasons of clarity etc. may be more desirable than the most frequently used ones?

It may seem that given these two possible approaches there may be greater merit in trying to standardize a language in the direction of the second possibility while at the same time attempting to maintain a healthy balance between the two. This approach has been followed in Dr. Dutton's course so that in time it may come to serve as a useful beginning point in any future discussion of the standardization of written, and ultimately spoken, Pidgin.

The learner using this course may well find himself in situations in which the Pidgin he hears may differ to some extent in matters of pronunciation, choice of words, or grammatical forms, from the one presented in this book. However, it is unlikely that such differences will seriously affect his understanding and ability to communicate 
with Pidgin speakers, and the situation will be reminiscent of that encountered by a speaker of standard southern English in Britain in speaking to people from the Midlands, northern England or Scotland, or by a speaker of the standard form of any European language in dialect areas of that language. To introduce the learner to this problem some Pidgin dialect materials have been included at the end of this course. Finally, I know that there are still things in this course that Dr. Dutton would like to improve upon, but I have urged him to publish it because of the increasing demand for a series of lessons more comprehensive than any currently available which can be used either for teaching or private study purposes. In doing so I hope that it will also contribute to an increase in the knowledge of New Guinea Pidgin by non-indigenous peoples, and help others improve their Pidgin, and that it will, as its final achievement, be instrumental in bringing about, and deepening, a better understanding between non-indigenous and indigenous peoples of Papua New Guinea.

S. A. Wurm

June, 1973 
Preface

Introduction

The Structure of the course

How to use the Lessons

$x 111$

Acknowledgements

xv1

xv111

Unit 1: LONG ROT

Pronunciation: Vowels

1.1 Personal Pronouns

1.2 Verbs--suffixation; tense; transitive/ intransitive

1.3 Stap 11

1.4 Bilong + verb: in order to 13

Text

Unit 2: LONG STUA

Pronunciation: 1. Consonants: $\mathrm{p}, \mathrm{t}, \mathrm{k} \quad 18$

2. Consonants: $\mathrm{f}, \mathrm{v}$

3. Consonants: $1, r \quad 19$

2.1 Pronouns: Dual and Trial 21

2.2 Laik i + verb: want to 23

2.3 Cardinal Numbers 1-100 24

2.4 Verbless Sentences 26

$\begin{array}{ll}\text { Text } & 29\end{array}$

Unit 3: LONG HAUS 34

Pronunciation: 1. Consonant Sequences 36

2. Stress and Rhythm 36

3.1 Possession 39

3.2 . Questions 41

3.3 Negation 43

3.4 Nouns: Singular and Plural Number 44

3.5 Transitive Verbs Unmarked by -im 46

$\begin{array}{ll}\text { Text } & 48\end{array}$ 
v111

Page

Unit 4: LONG NAIT

4.1 Bai + verb: Future Tense 55

4.2 Days and Dates $\quad 57$

$\begin{array}{lll}4.3 & \text { Time } & 60\end{array}$

4.4 Save + verb: Hab1tual Actions 64

Text $\quad 67$

Unit 5: LONG PAINIM WOK

5.1 Save + verb: Competence (know how to) 75

5.2 Inap + verb: Ab1l1ty (physically capable) $\quad 77$

5.3 Bin + verb: Past Tense 79

5.4 Verb + gen: Repeated Actions 81

Text 83

Unit 6: LONG PATI 89

6.1 Pronouns: 01 geta Forms 94

6.2 Beginning Relative Clauses (who, which, that) 95

6.3 Adjectives (-pela Forms) 98

6.4 Klostu + verb: about to, nearly, almost 101

Text 102

$\begin{array}{lll}\text { Unit 7: } & \text { LONG OPIS } & 107\end{array}$

7.1 Ken + verb: Permission 110

7.2 Negat1ve Imperat1ves (no, no ken, nogut) 111

7.3 More on Verbs (Stat1ve, $\mathrm{V}+$ long, $\mathrm{V}+\mathrm{im}$ ) 114

7.4 Reason Clauses (because) 118

7.5 More on Relative Clauses (to whom, whoever) 120

Text 122

Unit 8: LONG KIRAPIM WOK 128

8.1 Kirap + verb: begin to do something 130

8.2. Emphat1c Pronouns: yet, tasol, wanpela 131

8.3 Conditional Clauses (sapos) 133

8.4 Negat1ve Imperative (maski) 137

8.5 St1ll More on Relative Clauses (where, what) 138

Text 140

Unit 9: LONG WOK 145

9.1 Verb + i stap: Continuous Action 148

9.2 Verb + pinis: Completed Action 150

9.3 Time Clauses 153

9.4 More on Adjectives (Noun Followers) 157

Text 


\section{INTRODUCTION}

Conversational New Guinea Pidgin is an introductory language learning course in New Gulnea Pldgin. It is a revised version of a set of lessons developed and used for teaching the essentlals of this language to beginning students in part-time and intensive courses at the Australian National University over the past few years. ${ }^{l}$ As such $1 t$ has been designed primarlly for teaching purposes where there are competent instructors and modern language learning facllitles avallable, although 1t can be, and has been used quite successfully for selfteaching purposes by those unable to attend such courses.

The alm of the course 1s, as the title suggests, the development of conversational fluency in New Guinea Pldgin, that is, the development of the abllity to converse freely and easily w1th Papuans and New Guineans about everyday events. This 1 s felt to be 1mportant as New Guinea Pldgin 1s, after all, first and foremost a spoken language and only secondly a written one--although this latter aspect is now becoming increasingly important. Besldes, learning to read and write New Guinea Pldgin can be learnt in a few minutes and practised privately once one knows how the language is pronounced and used.

Thus the emphasis in the course is on listening to the language and on speaking it at normal speed, and all the exercises are designed to give the student as much practice as possible in these skills in the time avallable. There are no reading exercises (except for those in which the student is asked to write down what the speaker is saying on the tape and in which the emphasis is as much on sharpening up the student's powers of discrimination as on giving the student practice in writing) and the student is advised to resist the temptation to "get through" exercises and lessons with the least pain and effort by reading answers from the textbook. This is important because reading the answers not only destroys effort but ultimately slows down learn1ng. However, most students will find 1t difficult to do without this crutch at first simply because most of us have become so dependent upon reading and so conditioned to learning through 1t. But on the other hand this does not mean that the textbook should not be consulted at all--obviously it must be, to understand and learn new vocabulary or structures, to clarify what is being sald on the tape and/ or to use for practice away from the laboratory after the lesson has flrst been heard on tape. However, as a general rule, all the

${ }^{1}$ I should like to thank the Australian National University for its support and funds in running these courses as part of its Continuing Education Programme. 
learning should be done from the tapes and the student should make every effort to do this according to the general schema set out below In the section entitled "How to Use the Lessons" unt1l he (or his instructor) is satisfled that he has mastered the material presented.

Yet mere working through the materials in the way indicated will in itself not be sufficlent to ensure conversational fluency. The student must be prepared to go beyond that and to use what he knows as much as possible--the Classroom Exerclses and Reading List included in this volume will, I hope, give him some assistance in this regard, but there is no substitute for live practice with fellow learners, and especially w1th native speakers whenever and wherever possible.

Finally, a word of advice for the potential user who is also a native speaker of English, and that is that he should be aware that he, more than any other, is golng to experlence particular problems in learning New Gulnea Pldgin which native speakers of other languages are not. This is because New Guinea P1dgin is so closely related to English in much of 1ts vocabulary and structure yet so subtly different from 1t in lots of ways that the English speaker of ten finds it difflcult to keep himself orlentated to the differences and hence to know when he is speaking "real Pldgin" and not some more English-like version of it that is known locally throughout Papua New Guinea as tok masta (11t. European speech). The non-English speaker does not have this problem because he approaches the language from a different language background and learns 1t like any other forelgn language. So the English speaker must be careful of what he is about otherwise he will simply carry over his English speaking hablts into P1dgin without realizing that he is doing so. This would not only be detrimental to his language learning but tends to perpetuate the old but dying att1tude that the language is nothing more than broken English, or baby talk, whlch can be made up as one goes along.

In this course I have attempted to assist the English speaker overcome these problems by providing pronunclation exercises designed to help him pronounce Pldgin words in a Pldgin way; by concentrating on those aspects of the language which are different from English while leaving those features of 1 t which are simllar to English to be learned incldentally; and by glving the learner as much practice as possible in listening to the language spoken by native speakers. I have also attempted to make the lessons interesting, useful, and culturally relevant though this is rather difficult in these important times of change for Papua New Guinea. However, if they serve to teach someone something about New Guinea Pldgin and help overcome some of the prefudices against it I shall feel that the task of publishing 
them has been worthwhile. Of course the learner should also realize that New Guinea Pidgin, like all other pidgins, is not completely consistent in either its grammar or pronunciation and has alternative forms for some of its vocabulary. The forms one is likely to hear and use will vary from place to place and from speaker to speaker. Some of these variations are noted in Fr. Mihalic's The Jacaranda Dictionary and Grammar of Melanesian Pidgin referred to in the Reading List at the end of this volume, others are not. In a course such as this it is not practical to attempt to cover all aspects of the language so that some selection has to be made. In places where I have had to make choices between regional preferences and several related structures expressing the same idea I have chosen one for the student to learn and actively control, while leaving the others for him to learn himself through reading and/or experience. In cases where there are competing vocabulary forms for the same thing (e.g., natnat and moskito for mosquito; the numerals etc.) I have generally used the un-English forms, partly to overcome the tendency for English speakers to substitute English words at will and partly to maintain a particular flavour of the language. However, to restore some balance to this bias and to help the student become acquainted with the kinds of variation across New Guinea a special lesson has been included at the end of this course which is referred to again in the next section.

\section{THE STRUCTURE OF THE COURSE}

The basis of the course is the series of tape-recorded units, or lessons, corresponding to those contained in this volume. There are sixteen such lessons, each approximately one hour in length. The first fifteen of these cover the main structures and vocabulary of the language while the sixteenth is a special one which is designed to give the learner some idea of the variations he is likely to encounter from speaker to speaker across New Guinea and of the relationship of this pidgin to its sisters in the Solomon Islands and the New Hebrides nearby.

Each of the first fifteen lessons introduces approximately the same amount of new material for the student to learn and use and all are similar in design. Each consists of the following sections recorded on tape:

1. A Conversation

2. Useful Expressions

3. Vocabulary Expansion Exercises

4. Grammar Drills

5. Text 
These sections are separated by short excerpts of traditional New Guinea music taken from Music of New Guinea (Wattle recording D2, edited by Ray Sheridan, 1958) and each unit ends with something similar, or a present-day Pidgin song. Supplementary vocabulary related to each lesson is also supplied in the text book but is not recorded on tape. The student is not required to use this vocabulary in the recorded lessons; it is merely provided for him to enlarge his vocabulary if he so wishes. In the first three lessons pronunciation is also introduced and drilled.

Each of the tape-recorded sections of the lessons has the following characteristics:

\section{Conversations:}

These are of the short question-and-answer type designed to be as natural as possible while controlling the amount of new language material introduced. Each is connected in a story about a New Guinean, Dogare, and his married relative, Wanipe, in Port Moresby, the Administrative centre and largest town in Papua New Guinea. These characters act out a story of everyday life into which the main structures and vocabulary of New Guinea Pidgin are progressively introduced. The names of these characters are fictitious but have been designed to give English speakers practice in common Pidgin sounds that are most regularly mispronounced by them. Each conversation is accompanied by explanatory social and/or linguistic notes. Students should aim at learning each conversation of $f$ by heart since each contains all the material upon which the subsequent drills are based. To assist him in this each conversation is presented in the following way on the accompanying tapes:

1. Conversation for Listening

All the student does is listen to the conversation spoken by the actors.

2. Conversation for Learning The sentences of the conversation are repeated slowly by the instructor so that the student can learn them. Short sentences are said straight through. Longer sentences are built up in sections.

3. Conversation for Fluency

The sentences are again repeated but this time at normal speed so that the student can develop fluency of utterance. 
4. Conversation for Comprehension

The student again listens to the conversation

spoken by the actors.

Any section of a conversation can be replayed by the student for further practice and learning. All the conversations were recorded in the East Sep1k District.

useful Expressions:

This section contains expressions that are felt to be useful and relevant to the lesson at hand and for conversation generally, but which were otherwise difficult to incorporate into the Conversation. Vocabulary Expansion Exercises:

These are designed to expand the student's vocabulary. New 1tems are introduced into selected sentences from the conversation the student has already learned at the beginning of the unit. These selected sentences are referred to as "frames" in the drills. Two types of drills are used here and elsewhere--Simple Substitution and Progressive Substitution. In the former the student merely keeps repeating the same sentence materlal while substituting a new vocabulary 1 tem for one nominated in the frame. In the Progressive Substitution drill the student has to remember part of the last sentence he uttered while adding in the new plece given. Th1s latter exerclse calls for a greater effort from the student than the former. Each type of exercise is described again by the Instructor on the accompanying tape for Unit 1 but the student is thereafter expected to recognize the nature of the drill from its name, which is always given where relevant.

Grammar Drills

These are designed to drill particular grammatical structures already introduced in the conversations and to give flexibility to the student's command of those structures. Many different types of drills are used including the simple and progressive substitution types just described. Each section is introduced with a short description of the grammatical point belng drilled and concludes with an evaluation exerc1se to test the student's control of those points. In general four grammatical points are drilled in each unit.

Texts

These are typlcally short storles in the third person told by informants in actual field situations. Though not always easy to follow nor always on subjects directly related to the conversations they are 
$\mathrm{xv1}$

very good for giving students some ldea of the way P1dgin is actually used in story telling and how it may vary from speaker to speaker and from that taught in this course. All except the first of these texts come from the East Sep1k District. Translations follow the texts in the printed text book. These translations are falrly literal with more literal additions given in brackets to help the student see how the given translation was derived.

\section{HOW TO USE THE LESSONS}

Before beginning the actual learning programme, the student should flrst of all make sure that he has read through the preceding sections of this volume so that he has some 1dea of what is belng attempted and how this is being attempted. Then when he is ready to begin he should do so by working through the Conversation from the tape in the manner Indicated under the relevant heading in the section "The Structure of the Course" given above. Having done that he should then proceed 1mmediately to the Useful Expressions and the Vocabulary Expansion Exercises which he should work through several times. When he has been through these to his (and/or his instructor's) satisfaction, he should go back to the Conversation and try making up one for himself using some of the new vocabulary he has just learned. Finally, he should make sure that at the very least he knows how to ask the questions and/or give the commands that have been introduced in the Conversation and the Useful Expressions. He should then be ready to proceed to the Grammar Drills.

The Grammar sections contain no new material but merely give the student practice in manipulating what has already been learned. At the beginning of each such section the student should stop his machine and spend some time reading through the grammatical notes provided. These notes do not occur on tape and are not to be learned off by heart--they are there merely to help the student understand how the language "works" and to give him an ldea of what aspects of it are being drilled in the exercises that follow. All the grammar sections can be gone through at once but at their completion the student should again return to the Conversation and seek out the structures that have been drilled in those sections. In this way he will begin to apprec1ate how the conversations could be varled further, and hopefully, thereby Improve his knowledge of the language and of the use of the materials.

When the Text is reached it should be studied carefully--firstly, just by listening to 1 t and seeing how much of 1 t is 1mmediately 
intelligible, and subsequently, by either attempting to write it down in short bursts or by working through it from the text book. In doing this, however, the student should pay particular attention to how the texts are opened and closed and how sentences are joined together with items like olsem (na), orait (na), pinis, nau etc. When he is thoroughly acquainted with the text the student should then try retelling the story in his own words.

The Supplementary Vocabulary can be studied as time and inclination allow and the Classroom Exercises worked through with an instructor as relevant. Note, however, that the classroom exercises are representative only and of basic types which may be varied and repeated in different forms on different occasions.

Finally, note that in presenting the Pidgin materials in this volume I have adopted the spelling conventions suggested in Fr. Mihalic's The Jacaranda Dictionary and Grammar of Melanesian Pidgin already referred to. This dictionary-grammar also contains a wealth of other useful information that could not be conveniently included in this course so that the student would do well to consider acquiring a copy for reference purposes, especially if he intends pursuing his study of the language beyond that taught in this course. 


\section{ACKNOWLEDGEMENTS}

During the preparation and presentation of these materials I have been encouraged and generously assisted by friends and colleagues Professor S. A. Wurm, Drs. D. C. Laycock and D. Tryon, Peter and Jackie Mühlhäusler, and Jacques Guy of the Australian National University, Messrs. John Lynch, Tony Bais, Himony Lapiso, Songas Solomon and Mrs. Wasi Romney of the University of Papua New Guinea, and Dr. J. Z'Graggen, Anthropos Institute, Alexishafen, Madang. All have given freely of their time and materials, advice and voices whenever required. To them my most sincere thanks.

Yet I could not have done without Francis, Rimpington, and Doroti of Tumam Vilzage, East Sepik District, for the time and effort they devoted to recording the conversations used in this version of the course; nor could I have done without all those informants who supplied texts and whose contribution is acknowledged in relevant places throughout this volume. To them and again to Peter and Jackie Mühlhäusler who kindly organized and supervised the recording sessions, I am deeply indebted for providing, under difficult conditions, the set of recordings that constitute the backbone of this course.

And last, but by no means least, I should like to express my gratitude to Wattle Recordings for permission to reproduce exerpts of traditional music from their disc Music of New Guinea already referred to, Mr. Bryant Allen, Department of Human Geography, The Australian National University, for permission to reproduce some of the Pidgin songs he collected in the East Sepik District, and Mr. Mike Goodman, Department of Agriculture, Stock, and Fisheries, Papua New Guinea, for permission to reproduce a version of his hitherto unpublished Pidgin composition Mipela Mipela Didiman.

To all of these and those that have assisted in other less tangible ways, again, my most sincere thanks.

T. E. Dutton

Canberra

June 1973 


\section{UNIT 1}

\section{CON VERSATI ON}

\section{Long Rot}

Dogare i man bilong ${ }^{l} \mathrm{Niu}$ Gini.

Em i stap long Mosbi. Em i wokabaut long rot na wanpela wantok ${ }^{2}$ i lukim em:

Wantok: He, Dogare, yu kam a ${ }^{3}$

Dogare: Yes ${ }^{4} \mathrm{mi} k a m$.

Wantok: Yu stap we na yu kam?

Dogare: Mi stap long Boroko 5 na mi kam.

Wantok: Nau yu go we?

Dogare: Nogat. Mi wokabaut tasol. Yu go we?

Wantok: Mi go long taun.

Dogare: Bilong wanem?

Wantok: Mi go bilong kisim mani long beng. 6

Dogare: Orait yu go!

Wantok: Yes, apinun brata. 7
Dogare is a New Guinean. He is staying in Port Moresby. At this point he is walking along the road and is seen by a fellow New Guinean:

Heh, Dogare, hi!

$H i$ !

Where are you coming from?

I'm coming from Boroko.

Where are you off to now?

Nowhere. I'm just walking about. Where are you off to?'

I'm off to town.

Why?

I'm going to get some money from the bank.

ok, see you!

Yes, see you mate!

$\left[\right.$ Musik ${ }^{8}$ ]

$l_{B i}$ long and long are two of the most frequently used words in Pidgin. They correspond to many such prepositions in English as of, in, at, on, for, to, from, etc. Their uses will be introduced progressively throughout this course.

2 The word wantok in Pidgin has a wide variety of uses. Basically it means speaker of the same language but it may also be used as a friendly term of address between persons.not speaking the same language. See, for example a discussion of the extension of the meaning of this term by E. Wolfers in Hymes (1971:413-23). 
3 Between familiars greetings and farewells in Pidgin are normally of the type You've come huh?, You're here huh?, or You go!. With increasing sophistication and mobility however, the forms apinun goodafternoon, gutnait good-evening, good-night, gutmoning good-morning and gude good-day are becoming much more common.

${ }^{4}$ Yes/yesa both mean yes in Pidgin. The former is used when something else follows; the latter when nothing else follows or one is answering a person thought to be superior to oneself in some way.

${ }^{5}$ Boroko is a suburb of Port Moresby where many non-indigenous public servants are housed. Other parts of the town are known as Paga Point, Konedobu, Hanuabada, Badili, Kaugere, and Gordon's Estate. Locations are often named, however, after distances from the centre of town, e.g. fomail the four-mile, siklsmail the six-mize etc.

6 Brata (lit.) brother, like wantok has been extended in meaning to comrade, mate, between persons of like sex. Susa (lit.) sister would be similarly used if one were talking to a person of opposite sex.

7 Go in Pidgin means to move away from and is not necessarily equivalent to English go which may also be translated by wokabaut or raun in Pidgin. Furthermore go (and $\mathrm{kam}$ ) often behave irregularly in Pidgin grammar as will be seen later.

8

The traditional music heard throughout this unit is that of a bamboo Jew's harp which is used both as a serenading instrument and sometimes as an instrument to play off strange spirits when the owner walks into unfrequented territory. The recording comes from Sheridan (1958: side 2, track 1, item f).

\section{USEFUL EXPRESSIONS}

Yu save?

Nogat, mi no save.

Yes, mi save.

Yu tokim mi gen.

Yu tokim mi long Tok Pisin!

Yu tokim mi long Tok Inglis!

Yu pasim buk!

Yu opim buk!
Do you understand? Do you know? No, I don't understand; I don't know.

Yes, I understand; I know.

Tell me again; Repeat it!

Tell me in New Guinea Pidgin!

Telz me in English!

shut the book!

open the book!

\section{PRONUNCIATION}

While many Pldgin words are related to English ones the meanings and pronunclation of them are generally markedly different. Pidgin has fewer sounds than English does and pronounces them in different ways. The following exercises are designed to acqualnt you with the maln problem features of PIdgin pronunclation for English speakers. 


\section{Vowels}

In Pidgin the vowel sounds represented by the symbols $\mathbf{i}, \mathbf{e}, \mathbf{a}, \mathbf{0}$, $u$ present the greatest difficulty for English speakers because they often correspond to English long vowels or dipthongs. In the following exercise listen carefully for the differences between the related English and Pidgin words and mimic each of the Pidgin words after the instructor. These will be said twice. Ready?

Pidgin Sound Illustrated

i

e

a

$\circ$

u

\begin{tabular}{|c|c|}
\hline English & Pidgin \\
\hline pig & pik \\
\hline reef & rip \\
\hline kick & kik \\
\hline green & grin \\
\hline sleep & slip \\
\hline rain & ren \\
\hline paper & pepa \\
\hline place & ples \\
\hline Zeg & lek \\
\hline spade & spet \\
\hline cut & kat \\
\hline stop & stap \\
\hline hot & hat \\
\hline water & wara \\
\hline spark & spak \\
\hline photo & poto \\
\hline road & rot \\
\hline $\operatorname{cold}$ & kol \\
\hline cockatoo & koki \\
\hline talk & tok \\
\hline fuzz up & pulap \\
\hline cook & kuk \\
\hline brood & b lut \\
\hline school & skul \\
\hline good & gutpel \\
\hline
\end{tabular}

Now listen to the following Pidgin words and repeat them after the instructor paying particular attention to the common ending im. This is always pronounced clearly in Pidgin. Ready?

$\begin{array}{ll}\text { tokim } & \text { bringim } \\ \text { kisim } & \text { brukim } \\ \text { harim } & \text { givim } \\ \text { soim } & \text { bekim } \\ \text { lukim } & \text { katim }\end{array}$




\section{VOCABULARY EXPANSION EXERCISES}

In these exerclses you are golng to learn new vocabulary by changing old words for new ones given to you by the instructor's volce on the tape. In these exercises the instructor will begin with a sentence which he has taken from the conversation you have just learned and which he will call a "frame". You will repeat this frame after the instructor and then listen for the new words to be given to you as cues. When you hear these cues repeat the frame and add in the new words for the corresponding ones given in the frame. For example, suppose the instructor begins with the frame Mi go long taun and then gives the cue long stua, your answer should be Mi go long stua. Exercises of this kind are called Simple Substitution Exercises. Slightly different ones called Progressive Substitution Exerclses will be introduced and explained below. Ready?

\section{Exercise 1: Simple Substitution}

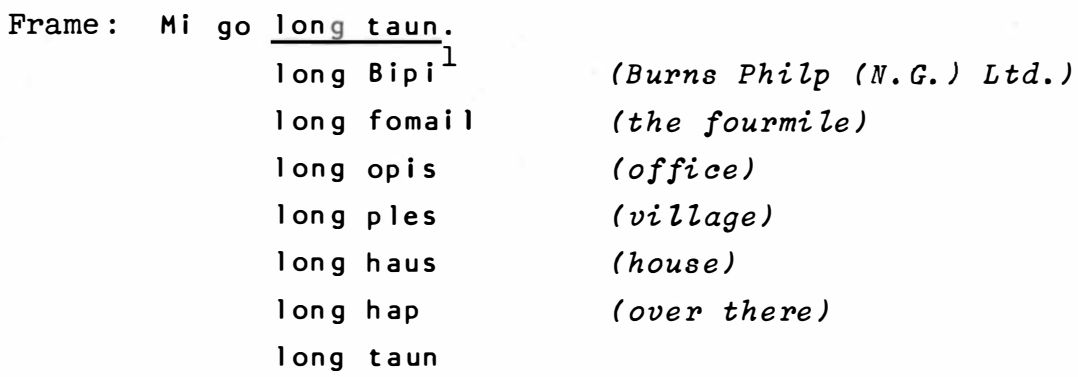

Exercise 2: Simple Substitution

\begin{tabular}{|c|c|c|c|c|}
\hline \multirow[t]{7}{*}{ Frame: } & \multirow[t]{7}{*}{ Dogare i man } & bilong & Niugini. ${ }^{2}$ & \\
\hline & & bilong & Ostrelya & (an Australian) \\
\hline & & bilong & Madang & (a man from Madang) \\
\hline & & bilong & Amerika & (an American) \\
\hline & & bilong & Is Sepik Distrik & $\begin{array}{l}\text { (a man from the East } \\
\text { Sepik District) }\end{array}$ \\
\hline & & bi long & $\operatorname{lnglan}$ & (an Englishman) \\
\hline & & bi long & Niugini & \\
\hline
\end{tabular}

${ }^{1}$ In most main towns of New Guinea Burns Philp (N.G.) Ltd. and Steamships Pty. Ltd. have large stores known locally as Bipi and Stimsip respectively.

2 For the purposes of this course man and meri will be used to refer to indigenous males and females of countries while masta and misis will be reserved for non-indigenous residents of Papua New Guinea. The differences between man and masta on the one hand and meri and misis on the other are more subtle than this but will not be discussed further here to avoid confusing the learner at this point. He should, however, be aware of the subtlety and be prepared to observe the differences in usage in his reading or in talking to or with Papuans and New Guineans. 
Exercise 3: Simple Substitution

Frame: Yu stap we na yu kam?

$\begin{array}{ll}\text { slip } & \text { (sleep) } \\ \text { sindaun } & \text { (sit down) } \\ \text { wok } & \text { (work) } \\ \text { baim rais } & \text { (buy rice) } \\ \text { kisimpe } & \text { (get paid) }\end{array}$

Exercise 4: Simple Substitution

Frame: Mi stap long Boroko na mi kam.

\begin{tabular}{|c|c|c|}
\hline Iong & bung & (market) \\
\hline long & gaden & (garden) \\
\hline long & haus & (house) \\
\hline long & Madang & (Madang) \\
\hline long & rum & (room) \\
\hline long & bus & (bush) \\
\hline ong & Boroko & \\
\hline
\end{tabular}

Exercise 5: Simple Substitution

Frame: Wanpela wantok i lukim em.

$\begin{array}{ll}\text { Wanpela masta } & \text { (European man) } \\ \text { Wanpela misis } & \text { (European woman) } \\ \text { Wanpela kiap } & \text { (Government officer) } \\ \text { Wanpela pikinini } & \text { (child) } \\ \text { Wanpela meri } & \text { (native woman) } \\ \text { Wanpela wantok } & \end{array}$

\section{Exercise 6: Progressive Substitution}

In exercises of this kind each new sentence that you make becomes a frame for the next substitution. That 1s, suppose the instructor begins with the frame Mi go bilong kisim mani long beng followed by the cue long rum your answer should be Mi go bilong kisim manl long rum. Th1s answer now becomes the frame and when the instructor gives the next cue you substitute that into this new sentence. For example, suppose the instructor's next cue was harim tok your answer should be Mi go bilong harim tok long rum. Ready? Here is the frame to begin with: 


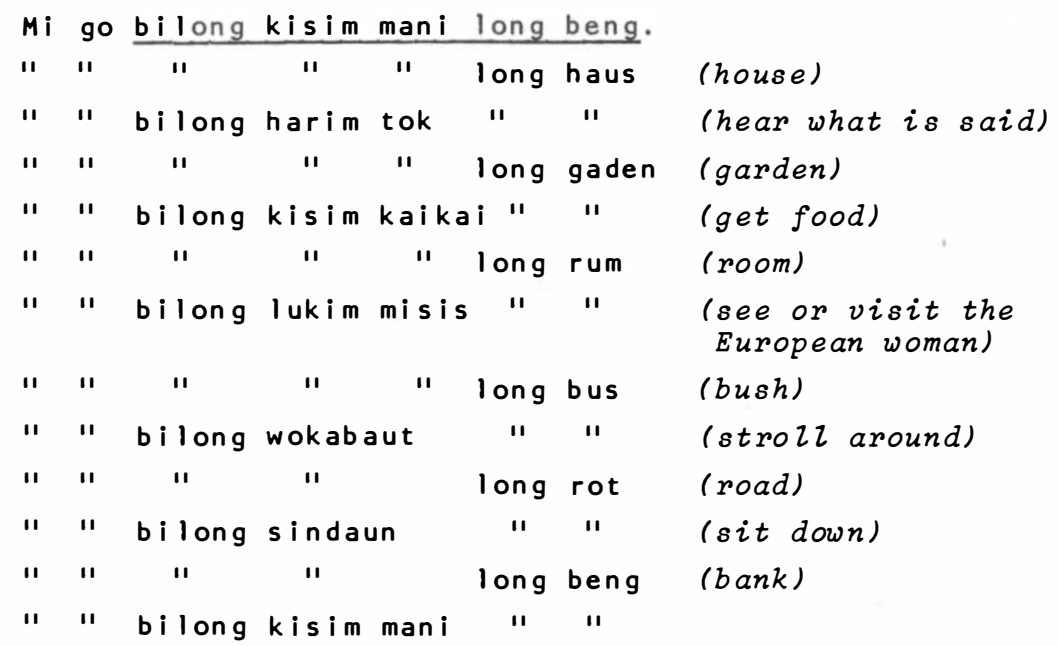

\section{Exercise 7: Progressive Substitution}

\begin{tabular}{|c|c|c|c|}
\hline \multirow[t]{9}{*}{ Frame: } & \multirow{2}{*}{$\frac{\text { Apinun }}{1 "}$} & \multicolumn{2}{|l|}{ brata. } \\
\hline & & wantok & (friend) \\
\hline & Gude & 11 & (Good-day) \\
\hline & $" 1$ & masta & $(s i r)$ \\
\hline & Gutnait & $" 1$ & (Good-night) \\
\hline & 11 & misis & (Madam) \\
\hline & Gut moning & 11 & (Good-morning) \\
\hline & 1111 & brata & (friend) \\
\hline & Apinun & 11 & \\
\hline
\end{tabular}

\section{GRAMMAR}

\subsection{PERSONAL PRONOUNS}

The principal pronouns in Pidgin are:

\begin{tabular}{lll} 
Pidgin & Refers to & English \\
$\mathbf{m i}$ & the speaker & I, me \\
yu & the person spoken to & you \\
em & the person or thing spoken about & $\begin{array}{l}\text { he, she, it, } \\
\text { him, her, it }\end{array}$ \\
yumi & the speaker and persons spoken to we (incl.), us (incl.) \\
mipela & the speakers and persons with him we (excl.), us (excl.) \\
& but not lncluding the person spo- & \\
yupela & the persons spoken to & you (pl.) \\
ol & the persons spoken about & they, them \\
\hline$I_{\text {Cf. Unit }}$ for dual and trial forms. &
\end{tabular}


There are four 1mportant differences between these P1dgin pronouns and English ones:

1. There are no separate pronouns for he, she, it in Pldgln. These are all em. Thus e $m$ i go long taun can mean in Pidgin elther he went to town or she went to town or it went to town.

2. In most Pldgin sentences all the subject pronouns except $\mathrm{mi}$ and yu are followed by $i$ which occurs between the pronoun and the verb, for example: 1

$$
\begin{aligned}
& \text { mi go long taun } \\
& \text { yu go long taun } \\
& \text { em i go long taun } \\
& \text { yumi i go long taun } \\
& \text { mipela i go long taun } \\
& \text { yupela i go long taun } \\
& \text { ol i go long taun. }
\end{aligned}
$$

Th1s particle is a most 1mportant part of the special structure of P1dgin and is usually referred to as the Predicative Particle or Predicate Marker. Its position relative to other 1tems in sentences will be 1llustrated and discussed as they are introduced later.

3. Pldgin distinguishes between yumi and mipela which are both represented as we in English. To distinguish the Pldgin forms in English yumi is sald to be we (inclusive), that is, we, including the person spoken to and mipela is sald to be we (exclusive), that 1s, we, exclusive of the person spoken to. Thus mipela $i$ go long taun means we (that is, my friends and I but not you) are going to town whereas yumi i go long taun means you and my friends and $I$ are going to town.

4. P1dgin pronouns do not change form like English ones do when they occur as objects of verbs or prepositions (like long or bilong). Thus whereas in English one says He sees me and not $H e$ sees $I$, In P1dgin one says em i lukim $\mathrm{mi}$, where $\mathrm{mi}$ is the same form as one uses in the beginning of sentences like mi lukim em $I$ see him.

\section{Practice Drills}

\section{Exercise 1: Simple Substitution}

Frame: $M i$ go long gaden.

$$
\text { (yu, em i, yumi i, mipela i, yupela i, ol i, mi) }
$$

\section{Exercise 2: Simple Substitution}

Frame: 01 i baim kaikai long bung.

$$
\text { (mipela i, yu, em i, yumi i, mi, yupela i, ol i) }
$$

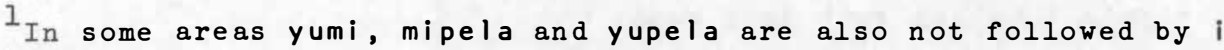
and some speakers do not distinguish between yumi and mipela.
} 
Exercise 3: Progressive Substitution

\begin{tabular}{|c|c|c|c|c|c|c|}
\hline \multirow[t]{14}{*}{ Frame: } & $\underline{M i}$ & & go & & I ong & haus \\
\hline & $E \mathrm{~m} \quad \mathrm{i}$ & & $" 1$ & & 11 & $" 1$ \\
\hline & 111 & & slip & & $" 1$ & $" 1$ \\
\hline & Yupela & $\mathbf{i}$ & 11 & & $"$ & 11 \\
\hline & 11 & "1 & lukim & man & $" 1$ & $"$ \\
\hline & $Y u$ & & 11 & $" 1$ & $" 1$ & $" 1$ \\
\hline & $" 1$ & & sindaur & & $" 1$ & $" 1$ \\
\hline & Mipela & $\mathbf{i}$ & 11 & & $"$ & $"$ \\
\hline & 11 & 11 & kaikai & rais & $s^{\prime \prime}$ & $" 1$ \\
\hline & $01 i$ & & 11 & 11 & $" 1$ & $" 1$ \\
\hline & 111 & & harim & tok & $" 1$ & $" 1$ \\
\hline & Yumi i & & 11 & $"$ & $" 1$ & 11 \\
\hline & 11 & go & $"$ & $" 1$ & $" 1$ & $"$ \\
\hline & Mi & 11 & $" 1$ & $" 1$ & $" 1$ & 11 \\
\hline
\end{tabular}

Evaluation Exercises

Exercise 1: Repeat the following sentences and say what they mean in English.

1. 01 i wok long opis.

(pause)

They work in the office.

2. Wanpela pikinini i go long bus.

(pause)

A child went to (or into) the bush.

3. Em i go long haus bilong kisimkaikai. (pause)

He (or she or It) went to the house to get food.

4. Wanpela man bilong Madang i slip long hap. (pause)

A man from Madang is sleeping over there.

5. Dogare i man bilong we? (pause)

What nationality is Dogare? or Where does Dogare come from?

Exercise 2: Give answers to the following questlons using the

Pidgin cues provided after each question. Ready?
1. Yu go we?
(long bus) (pause)
Mi go long bus.
2. 01 i stap we?
01 i stap long hap.
(long hap) (pause)
3. Yupela i kaikai rais we?
(long haus) (pause)
Mipela i kaikai rais long haus. 
4. Em i sindaun we?

Em i sindaun long rot.

5. Yupela i lukim masta we? (long opis) (pause)

Mipela i lukim masta long opis.

6. Yumi i kisim mani we?

(long beng) (pause)

Yumi i kisim mani long beng.

Exercise 3: How would you say the following things in Pidgin? In checking your answers agalnst the instructor's, listen carefully for the predicative marker $\mathbf{i}$. Th1s 1s most 1mportant here and in all other exercises. Ready?

1. The Government officer is listening to what is said in the house. (pause)

Kiap i harim tok long haus.

2. They are strolling around in the bush. (pause) 01 i wokabaut long bus.

3. Tell me in English. (pause) Yu tokim mi long tok Inglis.

4. Where are you (pl.) working? (pause) Yupela i wok we?

5. We (but not you) saw a child in the garden. (pause) Mipela i lukim wanpela pikinini long gaden.

\subsection{VERBS}

There are a number of differences between verbs in P1dgin and those in English which are 1mportant at this point:

1. Verbs in P1dgin do not add suffixes or change form in any way for different persons. Thus the same form go is used for all persons in Pldgin (e.g., mi go, ol $i$ go and em $i$ go) whereas in English go changes form (e.g., I go versus he goes ).

2. Verbs in P1dgin can refer to present, past or future act1ons unless they occur with adverbs (like yesterday, tomorrow) or with speclal auxiliary verbs or particles to indicate the time (or tense) of the action and/or the nature (or aspect) of 1 ( for example, whether it is complete, continuing, habltual etc.). Pldgin has a wide varlety of tense and aspect markers which w1ll be presented progressively later. Thus mi go long taun can mean (w1thout reference to any other information) I am going to town, I went to town or I' 22 go to town.

3. Verbs in Pidgin are of two general types: transitive and intransitive. Transitive verbs are those which take objects, e.g., baim in 01 i baim kaikai they bought food. In contrast to English, however, transitive verbs in Pldgin are generally different in form from intransitive 
ones. Thus transitive verbs usually end in -im, e.g., lukim, baim, harim, kisim while intransitive ones, like go, kam, sanap do not.

Practice Drills

Exercise 1: Simple Substitution

Frame: Mipela i sindaun long rot.

(ol, em, yupela, yumi, ol, mipela)

\section{Exercise 2: Simple Substitution}

Frame: Wanpela meri i kam long bung.

(baim kaikai, harim tok, stap, lukim misis, wok, kam)

Exercise 3: Progressive Substitution

\begin{tabular}{|c|c|c|c|c|c|c|}
\hline Frame: & $\mathrm{Em}$ & i & wok & & long & fomail. \\
\hline & $" 1$ & $\mathbf{i}$ & kisim & pe & " & 11 \\
\hline & mas ta & & $" 1$ & $" 1$ & $"$ & $" 1$ \\
\hline & 11 & $\mathbf{i}$ & go & & 11 & $" 1$ \\
\hline & mi pela & & " & & $" 1$ & $" 1$ \\
\hline & $" 1$ & $\mathbf{i}$ & baim & haus & 11 & $" 1$ \\
\hline & wanpe la misis & & $"$ & $"$ & $"$ & $" 1$ \\
\hline & 11 & i & stap & & 11 & $" 1$ \\
\hline & meri & & $" 1$ & & $"$ & $"$ \\
\hline & $"$ & $\mathbf{i}$ & luk im & $\mathrm{mi}$ & $" 1$ & $" 1$ \\
\hline & em & & $" 1$ & $" 1$ & $"$ & $"$ \\
\hline & 11 & i & wok & & $" 1$ & $" 1$ \\
\hline
\end{tabular}

Evaluation Exercises

Exercise 1: Change the verb in the following sentences to those given in English as cues:
1. Mipela i go long sikismail.
(Zive)
(pause)
Mipela i stap long sikismail.
2. Man i sindaun we?
(work)
(pause)
Man i wok we?
3. 01 i sanap bilong harim tok. (come to hear (pause)
01 i kam bilong harim tok.
what is 8 aid)
4. Yu sindaun!
Yu go long opis!
(go to the (pause) office)
5. Wantok i stap we?
(buy a house) (pause)
Wantok i baim haus we? 
Exercise 2: Now on your own say the following things. Remember in checking your answer against the instructor's to listen carefully for the predicative marker i. Ready?

1. He is living at Konedobu.

(pause)

Em i stap long Konedobu.

2. Boroko is in Port Moresby.

(pause)

Boroko i stap long Mosbi.

3. You (pl.) and I see the store in Boroko. (pause)

Yumi i lukim stua long Boroko.

4. They are working in Mt. Hagen. (pause)

01 i wok long Hagen.

5. A European man is sleeping in the village. (pause)

Wanpela masta i slip long ples.

\subsection{STAP}

This verb occurs very frequently in P1dgin. It corresponds to the 1dea of be, exist, stay, remain, live in English. It does not translate English stop in sentences like the machine has stopped. Th1s concept is translated by $i$ dai in Pidgin.

Practice Drills

Exercise 1: Simple Substitution

Frame: Stua i stap we?

(Boroko, masta, gaden, haus, rot, stua)

\section{Exercise 2: Simple Substitution}

Frame: Rot i stap long bus.

(meri, stua, haus, bung, pikinini, rot)

Exercise 3: Progressive Substitution

Frame: Haus i stap long hap.l

$\begin{array}{ccc}\text { masta " } & \text { " } \\ \text { " } & \text { " } & \text { "long Mosbi }\end{array}$

Konedobu " " "

" " " long taun

misis " " "

" "Iong Bipi

meri " " "

"1" 11 long hap

haus " "

l long hap is often pronounced lohap in Pidgin. 


\section{Evaluation Exercises}

Exercise 1: On your own ask where the following things are:
1. Ostrelya
(pause)
Ostrelya i stap we?
2. haus
(pause)
Haus i stap we?
3. opis
(pause)
Opis i stap we?
4. misis
(pause)
Misis i stap we?
5. $\operatorname{rot}$
(pause)
Rot i stap we?

Exercise 2: Give answers to the following questions. Cue words are given In English.
1. Pikinini i stap we? (store)
Pikinini i stap long stua.
2. Haus
"1"
(there) Haus
" " "
' hap
3. Bung
(Port Bung
1111
Mosb i
4. Wantok Moresby)
5. Beng
1" 11
(bush)
Wantok
11 " bus
" " $"\left(4-m i z_{e}\right)$ Beng
"1" fomail

Exercise 3: Ask some one the following questions in P1dgin:

1. Where are you (pl.) going? (pause)

Yupela i go we?

2. Where is the child?

(pause)

Pikinini i stap we?

3. Where are you staying?

(pause)

Yu stap we?

4. Where is the 6-mile?

(pause)

sikismail i stap we?

5. Where did you get the money? (pause)

Yu kisim mani we?

Exercise 4: Answer the following questions in Pldgin in the way Indlcated by the English answers given as cues. Ready?

1. Stua i stap we? (It is in Australia.) Em i stap long ostrelya.

2. Masta" " "(He is over there.)

Em i stap long hap.

3. Bung " " "They are in the

01 i stap long bus. bush.)

4. Misis" " (She is in the

Em i stap long haus.

5. Kiap " " "They are in the vizlage.)

01 i stap long ples. 
1.4 BILONG + VERB : in order to

In Pldgin in order to (do something) 1s expressed simply by placing bilong before the verb:

Example: Mi go bilong kisim mani I am going in order to get money

$$
\text { long beng. }
$$

from the bank.

But note that bilong is often omitted in normal conversation after the common verbs go/kam when the intention is clear from the context, e.g., Mi go kisim mani I'm going to get money. Note however, that one cannot do this if something else comes after go/kam. Thus one can say: Mi go kisim mani long beng or Mi go long beng bilong kisim mani for I'm going in order to get money from the bank, but one cannot say *Mi go long beng kisim mani.

\section{Practice Drills}

Exercise 1: Progressive Substitution

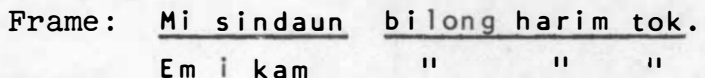

" " " bilong kisim pe.
Mi sanap " " " " " " " " " " " " " " " " " " " " " " " " " "
" "

Exercise 2: Repeat the following sentences in P1dgin and say what they mean in English:

1. Mi sindaun bilong lukim Dogare.

(pause)

I am sitting down to watch Dogare.

2. Kiap i stap bilong harim tok.

The Government officer is staying to listen to what is said.

3. Pikinini i go long stua bilong baim rais. (pause)

The child is going to the store to buy rice.

4. Em i kam bilong kisim pe.

(pause)

Helshe is coming to get paid.

5. 01 i sanap bilong wok.

(pause)

They are standing up to work.

Evaluation Exercises

Exercise 1: Give answers to the following questions using the P1dgin cues provided:

1. Yu go bilong wanem? (kisimpe) Mi go bilong kisimpe.

2. Em i wokabaut bilong wanem? 


$\begin{array}{lll}\text { 3. Bilong wanem ol i sindaun? } & \begin{array}{l}\text { (kaikai } \\ \text { rais) }\end{array} & \begin{array}{l}01 \text { i sindaun bilong } \\ \text { kaikai rais. }\end{array} \\ \text { 4. Yupela } i \text { kam bilong wanem? } & \begin{array}{l}\text { (baim } \\ \text { kaikai) }\end{array} & \begin{array}{l}\text { Mipela } \\ \text { baim kaikai. }\end{array} \\ \text { 5. Bilong wanem yu sanap? } & \text { (tokimmeri) } & \begin{array}{l}\text { Mi sanap bilong tokim } \\ \text { meri. }\end{array}\end{array}$

Exercise 2: How would you say the following things in Pidgin?

1. He is coming to get paid.

(pause)

Em i kam bilong kisim pe.

2. I am sitting down to watch Dogare.

(pause)

Mi sindaun bilong lukim Dogare.

3. We (excl.) are standing up to work.

(pause)

Mipela i sanap bilong wok.

4. You are coming in order to buy rice.

(pause)

Yu kam bilong baim rais.

5. She is staying in order to work in Burns Philp's store. (pause)

Em i stap bilong wok long Bipi.

\section{TEXT}

Listen to the following story and then say what it was about in English. Ready?

Asde ${ }^{1}$ mi go long taun. Mi lukim wanpela misis i stap long stimsip. Mi tok, "Misis yu go we?" Em i tok, "Mi go long bung long Koki." 3 orait, em i go na mi kam. Ating em i stap long bung. Em tasol. 5

ENGLISH TRANSLATION:

yesterday I went to town. I saw a European woman in (or at) Steamships Trading Co. store. I said, "Where are you going madam?" She said, "I'm going to the market at Koki." 3 All right, she went and I came (here). She's probably at the market (now). That's all (or That's the end). 5

Now to end this unit here is a Pidgin song from the Sepik. The background to this song is given by the singers as:

Taim em i liklik yet nau tupela bilongen i kisimem go long Namatanai long hap bilong Niu Ailan. Em i stap long Niu Ailan em inap long bikpela boi nau ol i rait long em $i$ go long ples. Nau em i tok olsem em i stap long Niu Ailan em i olsem ples bilongen. Em $i$ no save kambek long ples bilongen long papamama bilongen long Sepik. 
The words to the song are as follows:

$$
\begin{aligned}
& \text { Samting tru i stap long Namatanai } \\
& \text { Samting tru i stap long Niu Ailan } \\
& \text { Samting tru i stap long Namatanai } \\
& \text { Samting tru i stap long Niu Ailan } \\
& \text { Em tasol mi no inap long kam long ples } \\
& \text { Em tasol mi no inap long kam long ples }
\end{aligned}
$$

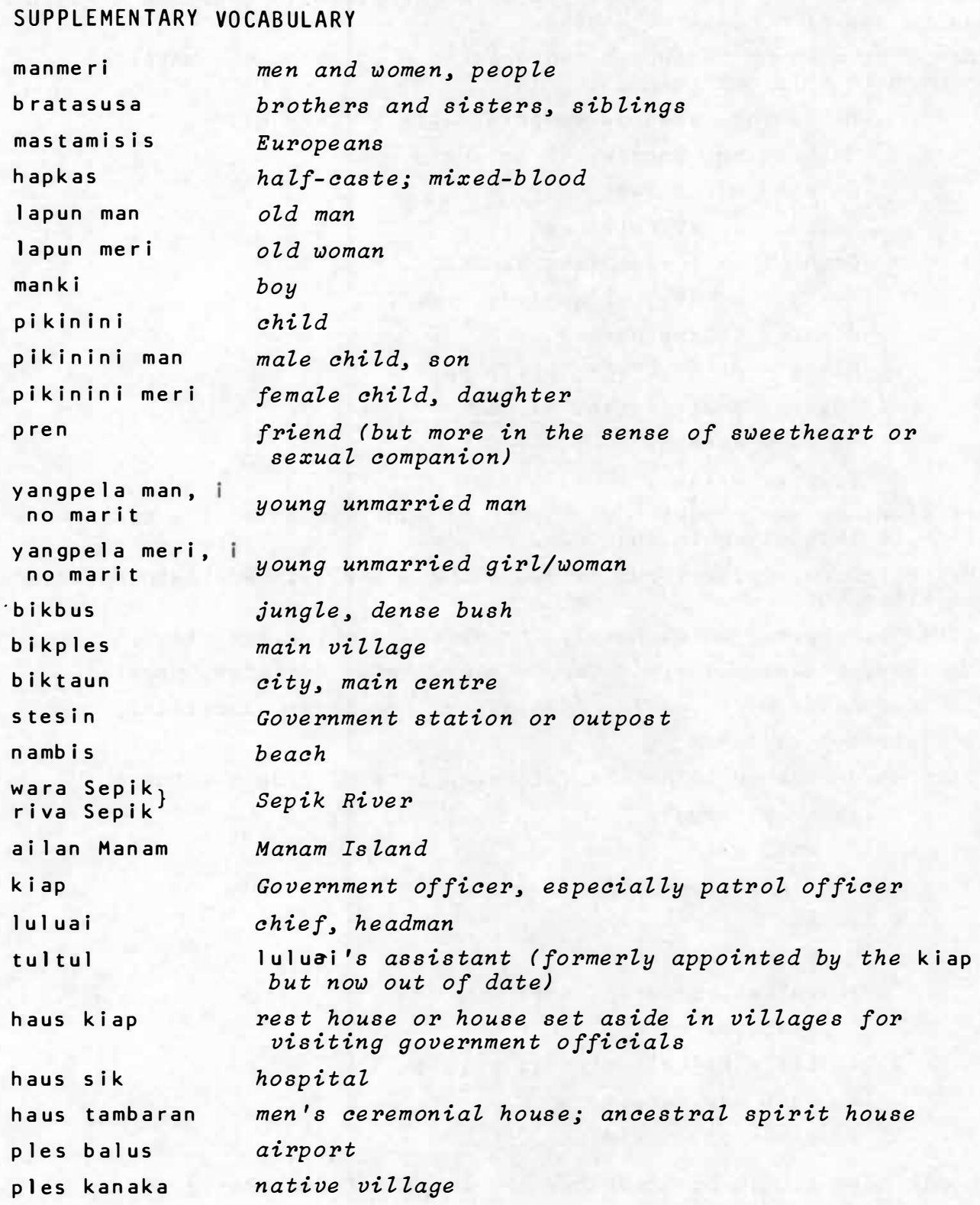


$\begin{array}{ll}\text { ples nogut } & \text { bad place } \\ \text { ples nating } & \text { clearing, empty space }\end{array}$

\section{CLASSROOM EXERCISES}

1. Short discussion of Papua New Guinea with students about 1 ts principal geographic features, the number and nature of 1 ts languages, its administrative districts and their main centres.

2. Introduction to Pidgin spelling with exercises to overcome English spelling and pronunciation habits.

3. Students make up their own conversations based on the material presented in this unit e.g.,

Mi go long stua na wanpela masta i lukim mi:

Masta: He, Dogare, yu go we?

Dogare: Mi go long opis.

Masta: Opis i stap we?

Dogare: Em i stap long Badili.

Masta: 0 sori, mi go long fomail.

Dogare: Bilong wanem?

Masta: Mi go bilong kisimpe.

Dogare: Orait masta, mi go.

Masta: Apinun.

Dogare: Apinun.

Other students can repeat the essence of what was said as a text similar to that given in the unit.

4. Write the following words as you think a New Guinea Pidgin speaker would write them:

country, course, development, Christian, club, association, against, independence, leader, member, Prime Minister, prophet, public, helicopter, nurse, plantation, pyrethrum, racialist, university, whiteman

5. Make up sentences using the following sets of Pidgin words:

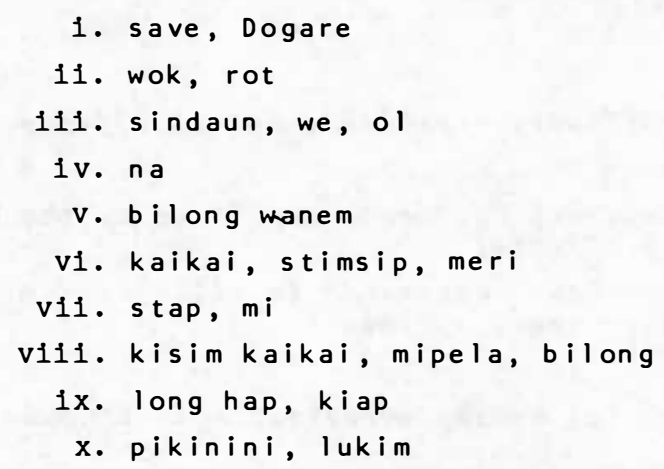

[The aim here should be accuracy, not length of sentence.] 


\section{UNIT 2}

\section{CONVERSATION}

\section{Long Stual}

Dogare na brata bilongen, Wanipe, Dogare and his brother, Wanipe, go tupela $\mathbf{i}$ go long stua. Tupela $\mathbf{i}$ to the store. The two of them lukim olgeta samting i stap insait look at everything in it and then long stua. Bihain stuakipa $i$ the storekeeper asks them:

askim tupela i tok:

Stuakipa: Yes plis. Yutupela $i$ laik i kisim wanem? ${ }^{2}$

Yes please? What do you two want to get?

Wanipe: Mitupela i laik i kisim kaikai--suga, rais, We want to get food--sugar, rice, lipti samting.

Stuakipa: Em hia--wanpela,

Here you are--one, two, three. tupela, tripela.

Wanipe: Em wanem?

What's that?

Stuakipa: Em suga!

That's sugar.

Wanipe: Em wanem?

What's that?

Stuakipa: Em rais! Na dispela

That's rice. And this is tea.

em lipti. Em tasol?

Is that all?

Wanipe: Em tasol, ating.

That's all, I guess. How much is 01 geta i kostim haumas? all that?

Stuakipa: Em et sen. ${ }^{3}$ Em wanpela ten sikis sen. Em That's 8\&. That's 16\&. That's tripela ten foa sen. olgeta i faipela ten et sen.

Olsem na Wanipe i givim tudola long stuakipa na stuakipa i bekim senis long Wanipe. Tupela i lusimstua $i$ go. 344. 584 altogether!

And so Wanipe gives the storekeeper $\$ 2$ and he gives wanipe back the change. The two of them leave the store.

\section{[Musik ${ }^{4}$ ]}

[footnotes overleaf] 


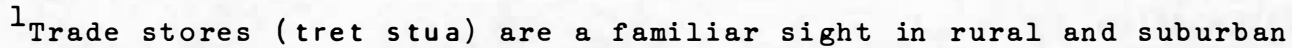
New Guinea. They sell limited lines of food and clothing and other useful items. The common foods like rice and sugar are usually sold in brown paper packets weighed into regular lots, generally of one or two pounds. Thus one asks for commodities like these by number rather than by weight.

\section{(1)} The questions involving wanem what here are really shortened forms of what should be longer ones using wanem samting. For example, Yutupela i laik i kisim wanem? is really the short form of Yutupela i laik i kisim wanem samting? In cases where the subject of verbless sentences (see section 2.4. below) is a noun the full form wanem samting must be used, e.g., one says Biskit i wanem samting? What is a biscuit? and not Biskit i wanem?

3 Australian decimal currency is used throughout New Guinea. Some speakers may still refer to the old currency items of shillings ( $s i$ ing) and pounds. (paun) however.

4

4 The traditional music heard throughout this unit comes from the north-east coast and tells how the singers once made a trading voyage to far off Bag Bag Island off the Maclay Coast. This recording comes from Sheridan (1958: side 1, track l, item h).

USEFUL EXPRESSIONS

Yu harim!

Yu sanap!

Yu kam sanap long ai bilong ol!

Tok bilong yu i kranki, i no stret.

Yu stretim tok olsem!

Aset! or Em nau!

\author{
Listen! \\ stand up! \\ Come and stand up in front of the \\ class. \\ What you have said is incorrect. \\ Correct what you have said like \\ this! \\ That's it! That's the way!
}

\section{PRONUNCIATION}

\section{Consonants: $p, t, k$}

Pidgin $p, t$, and $k$ are pronounced without aspiration or a following puff of air as in English pit for example.l Listen to the differences between the following sets of related English and Pidgin words and repeat the Pidgin ones:

$\begin{array}{cll}\text { Pidgin Sound Illustrated } & \text { English } & \text { Pidgin } \\ \mathrm{p} & \text { paper } & \text { pepa } \\ & \text { pawpaw } & \text { popo } \\ & \text { pipe } & \text { paip }\end{array}$

\footnotetext{
${ }^{1}$ In some areas of New Guinea $p$ and $b$ are pronounced as $f$ and $v$ respectively in which the lips are almost touching one another and not, as in English, with the lower lip touching the top teeth. In the same way $f$ and $v$ may be pronounced as $p$ and b respectively. See Mihalic (1971:5).
} 


\begin{tabular}{|c|c|c|}
\hline & $p i g$ & pik \\
\hline & cup & kap \\
\hline t & tea & $t i$ \\
\hline & tai 2 & tel \\
\hline & ten & ten \\
\hline & talk & tok \\
\hline & too & $\mathrm{tu}$ \\
\hline$k$ & cup & kap \\
\hline & cut & kat \\
\hline & cook & kuk \\
\hline & cockatoo & koki \\
\hline & kick & $k i k$ \\
\hline
\end{tabular}

\section{Consonants: $f, v$}

Pidgin sounds represented by $f$ and $v$ are pronounced with the lips almost touching one another and not, as in English, with the lower lip touching the top teeth. They often sound like $p$ and $b$ to English speakers and may be written that way. (See footnote previous page.) Listen to the following related English and Pidgin words and repeat the Pidgin ones.

English
four
five
Friday
fever
vinegar
vote

\section{Consonants: $1, r$}

Pidgin $I$ and $r$ are also unlike the corresponding English sounds. In Pidgin they are pronounced as flaps. That is, the tongue touches the roof of the mouth only once and very quickly in pronouncing the sound, very much like the $d$ sound one uses in pronouncing Saturday quickly in English. For many speakers there is no difference between these two sounds. Listen to the following related English and Pidgin words and repeat the Pidgin ones:

$\begin{array}{ll}\text { English } & \text { Pidgin } \\ \text { carry } & \text { karim } \\ \text { water } & \text { wara } \\ \text { Saturday } & \text { sarere } \\ \text { shut up } & \text { sarap } \\ \text { rubbish } & \text { rabis } \\ \text { rice } & \text { rais }\end{array}$




$\begin{array}{ll}\text { slack } & \text { slek } \\ \text { sleep } & \text { slip } \\ \text { Zeaf } & \text { lip } \\ \text { Zeg } & \text { lek }\end{array}$

\section{VOCABULARY EXPANSION EXERCISES}

\section{Exercise 1: Simple Substitution}

Frame: Tupela i lukim olgeta samting i stap insait long stua.

$$
\begin{aligned}
& \text { wanpela samting (something) } \\
& \text { sampela samting (some things) } \\
& \text { narapela samting (another thing) }{ }^{1} \\
& \text { planti samting (plenty of things) } \\
& \text { dispela samting (this thing) } \\
& \text { nupela samting (something new) } \\
& \text { bikpela samting (something big) } \\
& \text { liklik samting (something smazl) } \\
& \text { arapela samting (the other thing/s) }{ }^{1} \\
& \text { gutpela samting (something good) } \\
& \text { olgeta samting (everything) }
\end{aligned}
$$

Exercise 2: Simple Substitution

$\begin{array}{cll}\text { Frame: Yutupela i laik i kisim wanem? } & \\ & \text { mekim } & \text { (do) } \\ \text { wokim } & \text { (make, build) } \\ \text { brukim } & \text { (break) } \\ \text { haitim } & \text { (hide) } \\ \text { kukim } & \text { (cook) } \\ \text { rausim } & \text { (throw away) } \\ \text { salim } & \text { (send) } \\ \text { stilim } & \text { (steal) } \\ \text { kisim } & \end{array}$

\section{Exercise 3: Simple Substitution}

Frame: Mitupela i laik i kisim kaikai.

$\begin{array}{ll}\text { bret } & \text { (bread) } \\ \text { susu } & \text { (milk) } \\ \text { kiau } & \text { (eggs) } \\ \text { loliwara } & \text { (softdrink) }\end{array}$

${ }^{1}$ ote that narapela is always singular in reference while arapela can be both singular and plural. 


$\begin{array}{ll}\text { bia } & \text { (beer) } \\ \text { masis } & \text { (matches) } \\ \text { brus } & \text { (tobacco as grown in the } \\ \text { village) } & \text { (potatoes) } \\ \text { poteto } & \text { (soup) } \\ \text { sup } & \\ \text { kaikai } & \end{array}$

Exercise 4: Simple Substitution

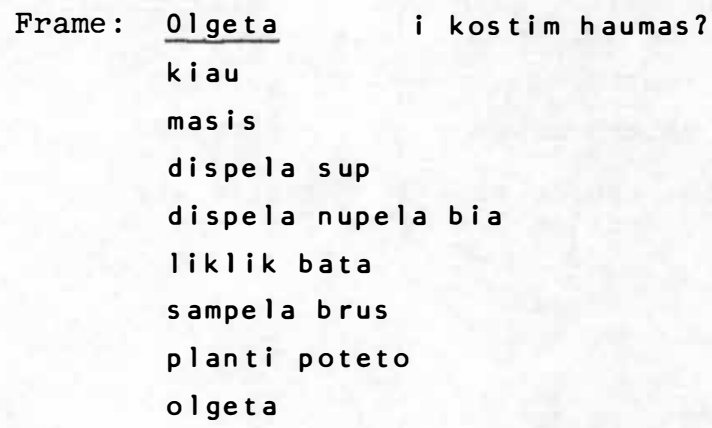

Exercise 5: Simple Substitution

Frame: Stuakipa i bekim senis long Wanipe.

$\begin{array}{ll}\text { givim bek senis } & \begin{array}{c}\text { (give or hand back the change } \\ \text { previously received)l } \\ \text { (callout to) }\end{array} \\ \text { singaut } & \begin{array}{l}\text { (answered by talking) } \\ \text { bekim tok }\end{array} \\ \text { soim senis } & \begin{array}{l}\text { (showed change) } \\ \text { (sent back a letter; answered } \\ \text { bekim letter) }\end{array} \\ \text { askim kwestin } & \text { (asked a question) } \\ \text { baimwilwil } & \text { (bought abicycle from) } \\ \text { bekim senis } & \end{array}$

\section{GRAMMAR}

\subsection{PRONOUNS: DUAL AND TRIAL}

In Pidgin it is customary to refer to the number of persons or things involved in an action especially if there are only two or three. This is done by adding the numerals tupela, tripela to the pronouns $\mathrm{mi}, \mathrm{yu}, \mathrm{em}$, yumi. Thus the set of pronouns given in Unit 1 should now be expanded to include at least the following:

\footnotetext{
${ }^{1}$ Note the difference between bekim and givimbek. The former means to exchange, the latter to return an item previously received or accepted.
} 


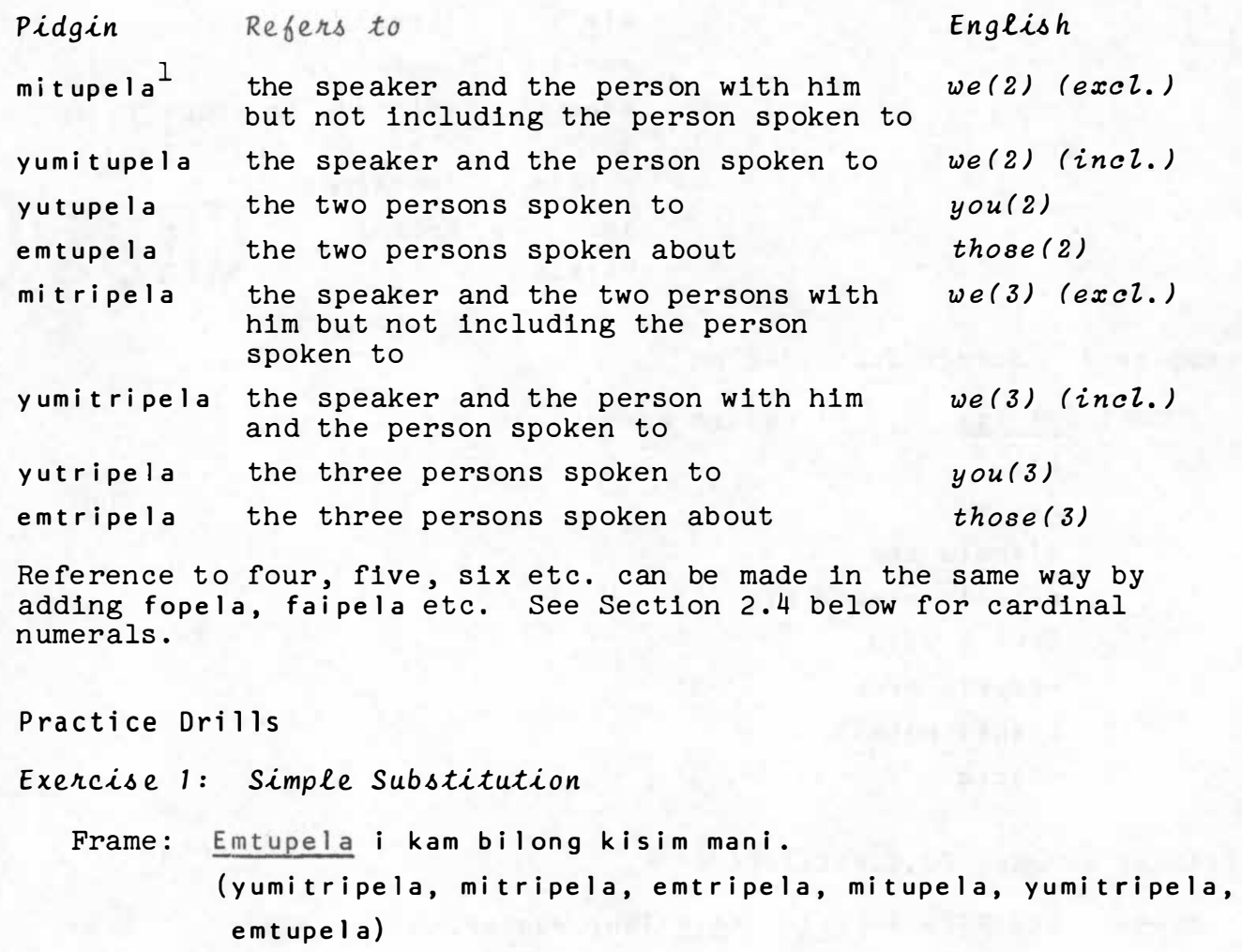

Practice Drills

Exercise 1: Simple Substitution

Frame: Emtupela i kam bilong kisim mani.

(yumitripela, mitripela, emtripela, mitupela, yumitripela, emt upe la)

Exercise 2: Progressive Substitution

Frame: Yumitripela istilimmeri.

Emtupela " " "

Yutupela " " "

" i rausim sampela kiau.

Mitupela $" \|$ "

"i bekim tok long misis.

Yumitripela" " " "

" istilimmeri.

Evaluation Exercise

Repeat the following Pidgin sentences and say what they mean in English.

1. Yutupela i givim sampela kiau long mi. (pause)

you(2) are giving some eggs to me.

${ }^{1}$ Note that these are written together in Pidgin. 
2. Mitripela i lukim tupela pik long gaden.

(pause)

We(3) (excl.) saw two pigs in the garden.

3. Yufopela i go we?

(pause)

Where are you(4) going?

4. Emtripela i laik i brukim wanem?

(pause)

What do those(3) want to break?

5. Mitupela i go bilong lukim Ostrelya.

(pause)

We(2) (excl.) are going in order to see Australia.

\subsection{LAIK I + VERB : want to}

Verbs preceded by 1 aik and the predicative marker $i$ indicate 1 actions which the subject wants, wishes, or desires to perform.

Examples: Yupela i laik i baim wanem? What do you (pl.) want to buy? 01 i laik i kukim kaikai. They want to cook food.

\section{Practice Drills}

\section{Exercise 1: Simple Substitution}

Frame: Em i laik i wokim haus.

(opim buk, baimwilwil, stretim tok, rausim lipti, lusim ples i go, wokim haus)

\section{Exercise 2: Simple Substitution}

Frame: Yupela i laik i go we?

(putim rais, salim buk i go, kisim wara, haitimbret, sindaun, go)

Exercise 3: Progressive Substitution

\begin{tabular}{|c|c|c|c|c|c|c|}
\hline \multirow[t]{12}{*}{ Frame: } & 이 & $\mathbf{i}$ & laik & $i$ & kisim & wanem? \\
\hline & " & $" 1$ & 11 & $" 1$ & wok im & 11 \\
\hline & Yupe la & " & $"$ & $" 1$ & $" 1$ & $"$ \\
\hline & 11 & $"$ & $"$ & $"$ & mekim & $"$ \\
\hline & $E m$ & $" 1$ & $"$ & $" 1$ & 11 & $"$ \\
\hline & $"$ & " & $"$ & $" 1$ & brukim & $"$ \\
\hline & $Y_{u}$ & "1 & $"$ & " & 11 & $"$ \\
\hline & 11 & " & $" 1$ & " & rausim & $"$ \\
\hline & Yumi & $"$ & $"$ & $"$ & $" 1$ & $"$ \\
\hline & 11 & "1 & " & " & stilim & $"$ \\
\hline & 01 & 11 & $"$ & $"$ & " & $"$ \\
\hline & 11 & "1 & $" 1$ & "1 & kis im & $" 1$ \\
\hline
\end{tabular}

INote here that many speakers do not use the predicative marker after 
laik as here suggested and so do not distinguish between this structure and that presented in Unit 15, Section 15.4: laik + verb: about to. Note further that laik is not used for to like doing such and such, which can be expressed in Pidgin in several ways (e.g. mi laikim long wokim saksak I like making sago) none of which is drilled in this course, however.

Exercise 2: How would you say the following things in Pidgin?

1. What do you want to do?

(pause)

Yu laik i mekim wanem?

2. I want to live in Moresby.

( $p$ ause)

Mi laik i stap long Mosbi.

3. He wants to give you the pig.

(pause)

Em i laik i givimpik long yu.

4. A 22 the European men want to come to Port Moresby.

olgeta masta i laik i kam long Mosbi.

(pause)

5. Where do they want to go?

(pause)

01 i laik i go we?

6. They want to see Australia.

(pause)

01 i laik i lukim Ostrelya.

\subsection{CARDINAL NUMBERS $1-100$}

The numbers 1-10 in Pidgin have two forms which differ only in that one set has - pela attached to a common part:

$\begin{aligned} \text { 1. wan } & \text { wanpela } \\ \text { 2. tu } & \text { tupela } \\ \text { 3. tri } & \text { tripela } \\ \text { 4. foa } & \text { fopela } \\ \text { 5. faiv } & \text { faipela } \\ \text { 6. sikis } & \text { sikispela } \\ \text { 7. seven } & \text { sevenpela } \\ \text { 8. et } & \text { etpela } \\ \text { 9. nain } & \text { nainpela } \\ \text { 10. ten } & \text { tenpela }\end{aligned}$

Those without -pela attached correspond to the names of the numbers in English. This set is used in the formation of numbers beyond 10, for mathematical operations like addition, subtraction, multiplication and division, and for counting money and telling the time, some of which will be presented in more detall later. Numbers between 10 and 100 have several forms, 1 but in these lessons we shall use the following which are all regularly derived. Here is an illustrative set.

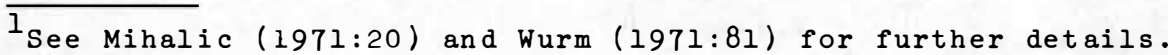



11. wanpela ten wan
12. wanpela ten tu
13. wanpela ten tri
14. wanpela ten foa
15. wanpela ten faiv
16. wanpela ten sikis
17. wanpela ten seven
18. wanpela ten et
19. wanpela ten nain

20. tupela ten

21. tupela ten wan

22. tupela ten tu

23. tupela ten tri
30. tripela ten
40. fopela ten
50. faipela ten
60. sikispela ten
70. sevenpela ten
80. etpela ten
90. nainpela ten

100. wan handet

In the classroom nating or not is used for nought or zero but outside it in everyday life the 1dea of nothing is expressed by $i$ no gat wanpela (lit. there is not one). Approximations are given by samting olsem e.g., Em i kisim samting olsem faipela ten sikis dola He got about \$56 (l1t. something like \$56).

\section{Presentation Drill}

Listen to and repeat the following Pldgin numbers counting from 1 to 20. Each number w1ll be sald once only.

$\begin{array}{ll}\text { wan } & \text { wanpela ten wan } \\ \text { tui } & \text { wanpela ten tu } \\ \text { foa } & \text { wanpela ten tri } \\ \text { faiv } & \text { wanpela ten foa } \\ \text { sikis } & \text { wanpela ten faiv } \\ \text { seven } & \text { wanpela ten sikis } \\ \text { et } & \text { wanpela ten seven } \\ \text { nain } & \text { wanpela ten et } \\ \text { ten } & \text { wanpela ten nain }\end{array}$


Practice Drills

Exercise 1: Simple Substitution

Frame: 01 i givim wanpela poteto long mi.

(sevenpela masis, samting olsem nainpela ten loliwara,

faipela pik, etpela dok, samting olsem tenpela kiau,

fopela stua, wanpela poteto)

\section{Exercise 2: Simple Substitution}

Frame: Mi lusim wandola long stua.

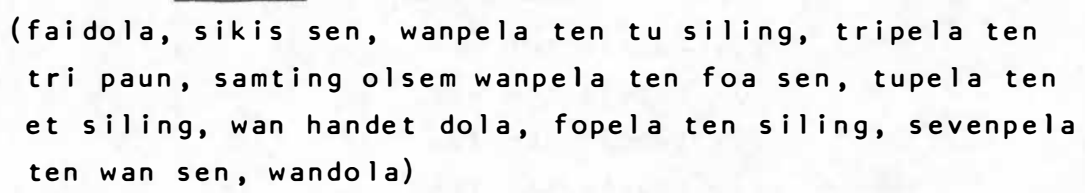

\section{Evaluation Exercise}

Open your book and give the Pidgin for the numbers shown in Sets 1 to 4. Begin after each set is identified by the instructor. You have a few seconds before answers are given. Ready?

Set 1: $3,13,1,11,6,16,9,19,2,12,5,15^{1}$

Set 2: $30,50,70,100,60,10,80$

Set 3: $5,63,18,37,21,76,99,1,11,16$

Set $4: 6, \$ 8,4 \xi, \$ 100,38, \$ 5,7 \xi, 2 /-, £ 9$

\subsection{VERBLESS SENTENCES}

Many sentences in Pidgin have no verbs. These sentences correspond to those in English which use the verb to be in the sense of equals, e.g., four and two are six or that is a book. In these sentences in Pidgin the predicate marker $i$ must occur except:

1. after the pronouns $\mathbf{m i}$ and $y u$ as already noted;

2. after the demonstrative pronoun em that (person or thing) as distinct from em he, she, it, e.g., compare

Em wanem?

Em i wanem?

Em hus at?

Em i husat?
What is that?

What is it?

Who is that?

Who is it?

$I_{\text {The coresponding answers are: }}$

Set 1: tri, wanpela ten tri, wan, wanpela ten wan, sikis, wanpela ten sikis, nain, wanpela ten nain, tu, wanpela ten tu, faiv, wanpela ten faiv

Set 2: tripela ten, faipela ten, sevenpela ten, wan handet, sikispela ten, ten or wanpela ten, etpela ten

[continued overleaf] 
Set 3: faiv, sikispela ten tri, wanpela ten et, tripela ten seven, tupela ten wan, sevenpela ten sikis, nainpela ten nain, wan, wanpela ten wan, wanpela ten sikis

Set 4: sikis, etdola, foa sen, wan handet dola, tripela ten et, faidola, seven sen, tu siling, nain paun

The distinction here can perhaps best be explained by the following example. Suppose one were walking along the road and suddenly saw something strange wriggling on the ground--one would probably jump and utter an appeal for help in recognizing this thing with Em wanem? and not $\mathrm{Em} i$ wanem? What is it? Supposing, however, that the strange object was identified as a harmless worm then one would enquire further about its nature with $E m$ i wanem? Em i samting nogut or wanem? What is it? Is it something bad or what? Answers to such questions follow the same structure. Consider, for example, the following pairs :

$$
\begin{array}{ll}
\text { Q: Em wanem? } & \text { What's that? } \\
\text { A: Em wanpela snek. } & \text { That's a snake. } \\
\text { Q: Em i wanem? } & \text { What is it? } \\
\text { A: Em i samting nogut. } & \text { It's a bad thing. }
\end{array}
$$

Finally, note that in questions in which the subject of a verbless sentence is a noun the form wanem samting must be used instead of just wanem, 1 e.g., Biskit i wanem samting? What is a biscuit? and not Biskit i wanem? This longer form can also be used for pronoun subjects but is not obligatory e.g., Em wanem samting? is as good as Em wanem?

\section{Practice Drills}

\section{Exercise 1: Simple Substitution}

Frame: Em suga.

$$
\text { (rais, lipti, tok Pisin, susu, kiau, suga) }
$$

\section{Exercise 2: Simple Substitution}

Frame: Dispela i loliwara.

$$
\text { (masis, brus, bia, wara, poteto, loliwara) }
$$

\section{Exercise 3: Simple Substitution}

Frame: Stua i wanem samting?

$$
\text { (man, kaikai, wantok, bung, pikinini, stua) }
$$

\footnotetext{
${ }^{1}$ See footnote 2 to the Conversation of this unit.
} 
Exercise 4: Progressive Substitution

Frame: Susu i wanpela samting.

" " narapela samting

Masis" " "

" " nupela samting

Bret " " "

" " gutpela samting

Loliwara " "

" wanpela samting

susu " "

Exercise 5: Progressive Substitution

Frame: $\frac{M i}{E m} \quad \frac{\operatorname{man}}{11}$.

" 1 meri

Yu

" pikinini

01 i 11

"I" masta

$\mathrm{Mi} \quad$ "

" man

Evaluation Exercises

Exercise 1: Answer the following questions using the cues provided. Listen carefully for the predicative marker i. Ready?

1. Em wanem? (egg)

2. Em husat? (the new European man)

3. Em i husat? (native woman)

4. Em wanem? (market)

5. Em husat? (a European woman)

6. Em i wanem? (something smalz)
Em kiau.

Em nupela masta.

Em i meri.

Em bung.

Em wanpela misis.

Em i liklik samting.

Exercise 2: Repeat the following P1dgin sentences and say what they mean in English.
1. Em husat?
(pause)
Who is that?
2. Bret $i$ wanem samting?
(pause)
3. Em i wanem?
(pause)
What is bread?
4. Dispela i wanem samting? (pause)
What is it?
5. Em wanem?
(pause)
What is this?
What is that? 
TEXT

Listen to the following story recorded at Drekikir in the East Sepik District and then say what it was about in English. Here is the text:

Mi laik stori long stua bilong mipela ol kristen. ${ }^{1}$ Dispela stua mipela i bin kirapim, em stua bilong wasman. ${ }^{2}$ olgeta wasman ol $i$ stap miting, na mipela i tok, "Mipela i kirapim wanpela stua bilong mipela." Orait, mipela i putim em faiv dola faiv dola. Orait, na inapim ${ }^{3}$ mipela nau na mipela i kirapim dispela stua. Mipela i kirapim dispela stua, na ol misin ${ }^{4}$ hia helpimmipela nau, na ol i oda $^{5}$ long olgeta samting bilong mipela, long mani bilong mipela yet. ${ }^{6}$ Orait na, ol i salim i kam long stua bilong mipela, na taim mipela laik salim ol samting long stua, man i kam baim, taim ol i baim em rais, ol i givimmipela tu siling na mipela givim ol tu siling pepa rais $^{7}$ yet. Orait, ol i givim mipela tri siling, mipela i skelimyet long pepa bilong tri siling yet. Orait, ol samting--ol samting $i$ kos bilong em inap long tu siling, mipela i givimol tu siling. 01 samting kos bilongen inap long tri siling, mipela i givim ol tri siling. Orait, planti man long olgeta hap tu ol i laikim stuabilong mipela na ol i kam long kisim ol samting--long stua bilong mipela-stua bilong kristen. Na i no gat ol smok samting, no i no gat ol samting, dring o wanem samting, i no inap long stap insait long stua bilong mipela, nogat--stua bilong kristen. Mipela i putim olgeta gutpela samting tasol, na ol smok na ol samting olsem nogat. 01 sigaret na ol Kapsten samting, i no stap long stua bilong mipela, niuspepa na ol tabak tu i no stap long stuabilong mipela. Mipela $i$ putim ol rais na ol mit ${ }^{8}$ na ol gutpela samting tasol. Orait na planti man tu ol i save laikim long baim ol samting long stua bilong mipela. Orait mani i bin kamap na mipela i bin subim long sek ${ }^{9}$ bilong mipela go long beng bilong gavman.

Em tasol.

[Playing time: 2 minutes]

\footnotetext{
$l_{k r i s t e n}=$ Protestants in this context (as against Popi or Catholics, these not being considered Christian)

${ }^{2}$ wasman $=$ caretakers, guard, church elders (probably in this context)

$3_{\text {in ap im }}=$ to give enough

4 ol misin $=$ the people of the mission. The reference is to the members of the South Seas Evangelical Mission.

5 oda (actually pronounced honda, a reflection of the speaker's mother tongue) $=$ order
} 
$6_{\text {mipela yet }}=$ our very own

7 pepa rais $=$ paper bag of rice

8 ol rais na ol mit. One would not have expected the plural markers ol here.

9 sek $=$ cheque $($ account $)$

ENGLISH TRANSLATION :

I want to tell you about the store belonging to us Protestants. This store which we built belongs to our church elders. All of them were having a meeting and we said, "We are putting up a store (for us)." So we each put in $\$ 5$ towards $i t$, and when we had sufficient (funds) we began the store. We built this store and the people of the mission here help us now. They order everything for us with our own money. Then (goods) are sent to our store and when we want to sell things in the store people come and buy (them). When they buy rice they give us two shillings and we give them a packet of rice worth two shillings. If they give us $3 /$ - we balance that with a packet worth 3/-. So things costing 2/- are given for 2/- (and) things costing 3/- are given for 3/-. And so many folk from all over the place like our store and come to get things--at our store--the Protestants' store. But there is no tobacco and (similar) things. No. There are no things like alcoholic liquor or whatever. They're not allowed in our store--in (our) Protestans' store. We only put good things (in $i t$ ) and not smokes and things like that. Cigarettes and "Capstans" and other things are not (to be found) in our store-newspaper and tobacco too are not (to be found) in our store. We put rice and tinned meat and only good things. And so plenty of people also like to buy things from our store. And so our money increases and we put it in our cheque (account) and bank it in the government bank.

That's alz.

Now to end this unit here is a Pidgin lament for a broken assignation. The words to this song are:

Wanpela meri i raitim pas long $\mathrm{mi}^{l}$

Wanpela meri i raitim pas long mi

Em i tok, bai mi go daun long wetimem, wetim em

Mi kirap long biknait mi go daun long wetim em

Mi go wet wet nating tulait hia.

Em i tok bai mi go daun long wetim em, wetim em

Mi kirap long biknait mi godaun long wetim em

Mi go wet wet nating tulait hia.

$\overline{l_{\text {Note how }}}$ the singers add a vowel a before and after long. 


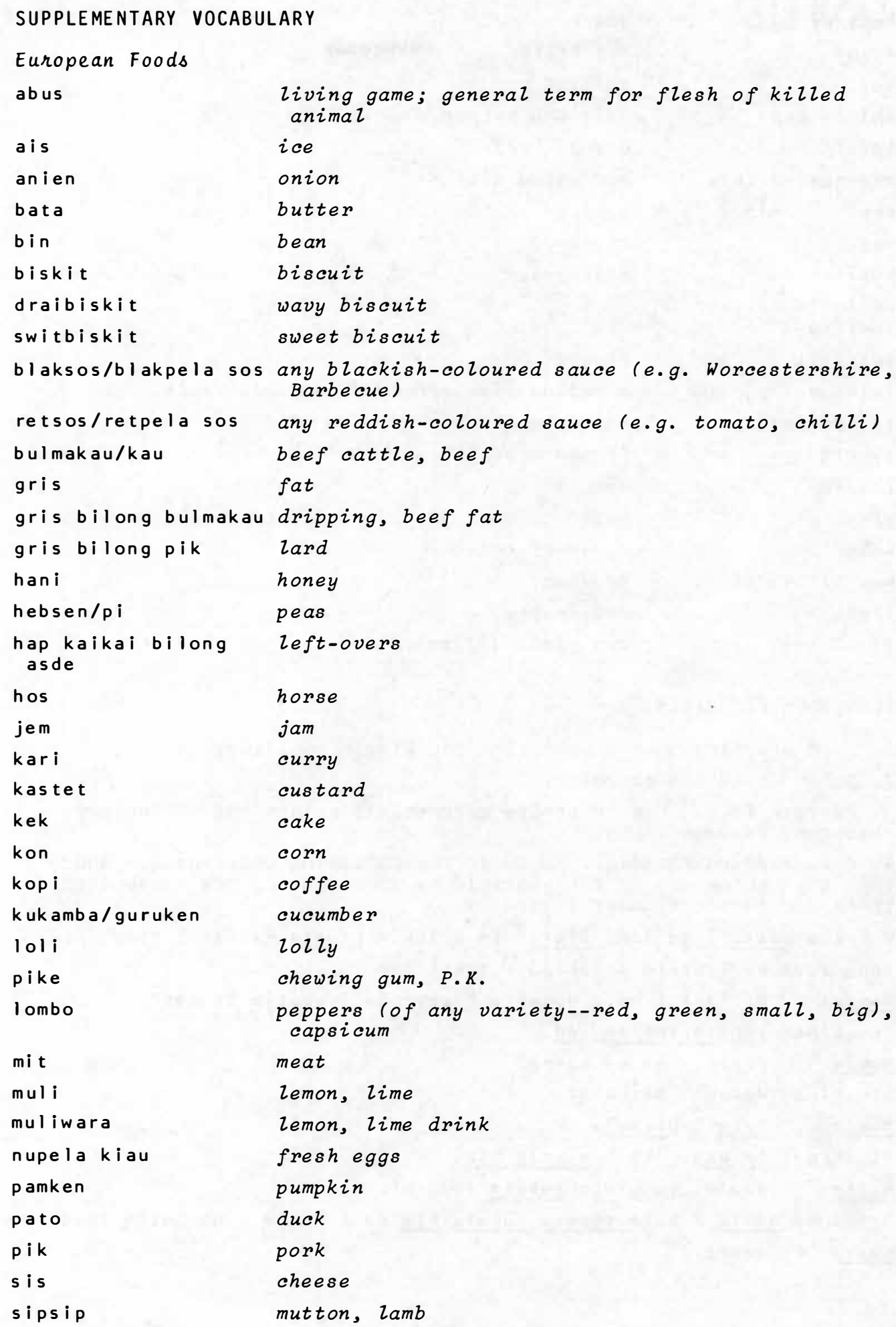




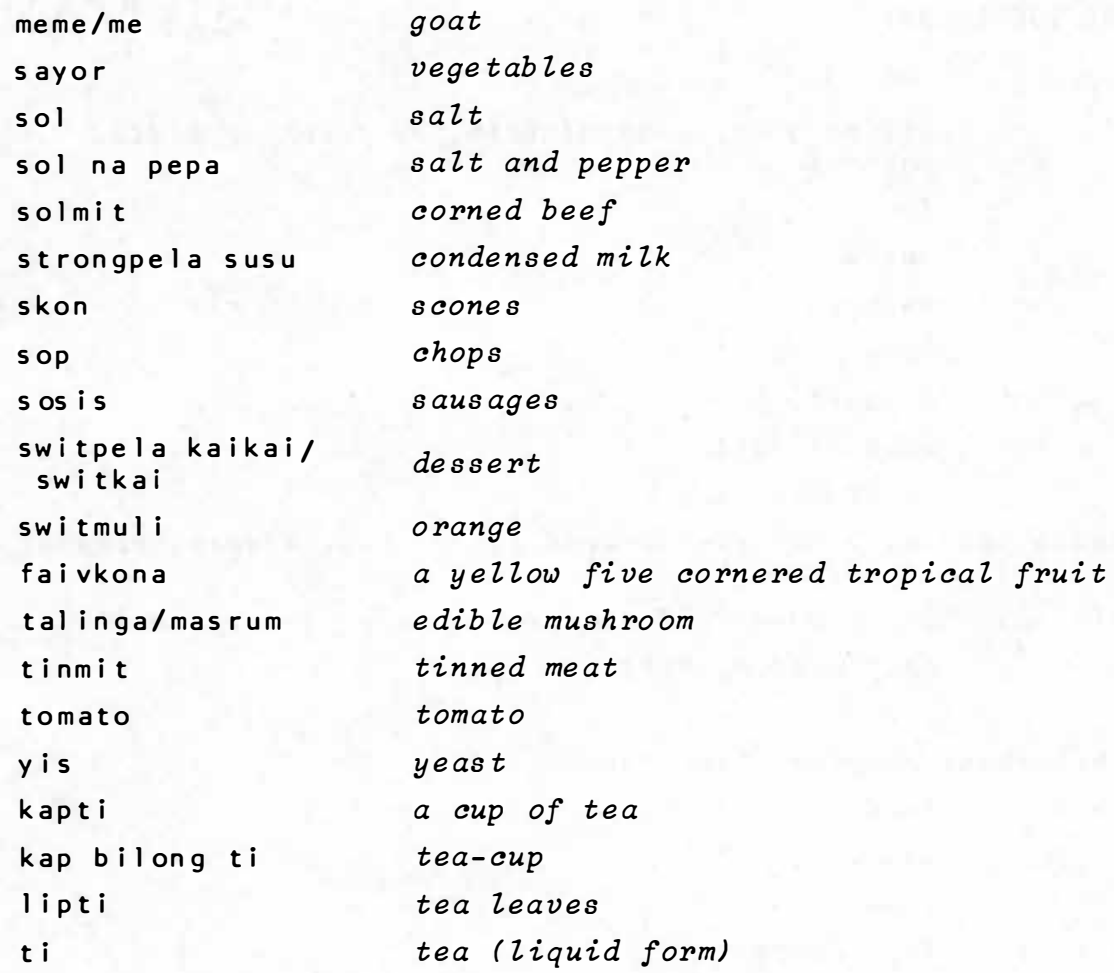

\section{CLASSROOM EXERCISES}

1. More practise on pronunciation and Pidgin spelling.

2. Short dictation exercise.

3. Picture Talk. Use to revise grammatical points and vocabulary presented so far.

4. Conversation Exercise. Look at the following conversation and then try making one up for yourself by substituting new vocabulary items for the ones underlined:

Wanpela masta i go long Bipi. Em i lukim olgeta kaikai i stap insait long stua na i askim stuakipa i tok:

Masta: Mi laik i baim wanpela bret. Em i kostim haumas?

Stuakipa: Tupela ten tu sen.

Masta: Orait. Na em wanem?

Stuakipa: Wanem? Dispela?

Masta: Yesa. Dispela.

Stuakipa: Em bia. Em i nupela bia.

Masta: Orait, yu givim tupela long mi.

orait na masta i baim tupela nupela bia na i kisim i go putim long

haus. Em tasol. 
5. Language Game: Cumulative Text. Students build up a text about going shopping by adding a sentence to ones given by others. The exercise begins with one student giving a sentence. The next student repeats that sentence and adds a new sentence. The next student repeats these and adds a new one. And so on until the text becomes unmanageable.

6. Fill in the gaps with suitable words:

1. Dispela ..... samting i kostim haumas?

11. Meri i...p pas long mi.

111. Em ....?

1v. Rupa i ..... wilwil long Bipi.

v. Brus i kostim.....

vi. Mi no.... bilong yu.

vi1. Emtupela i laik i kisim.....

vi11. .... laik i mekim wanem?

1x. Bret i gutpela .....

$x$. Meme .... wanem samting?

7. Name all the European foods that you have learned so far that begin in Pidgin with the sounds $\mathrm{p}, \mathrm{s}, \mathrm{b}, \mathrm{g}$. 


\section{UIVIT 3}

CONVERSATION

Long Haus

Tupela brata $i$ go bek long haus bilong Wanipe. Meri bilongen, MALOLO, 1 wetim tupela bilong redim kaikai.

MALOLO: Yutupela i kam a?

Wanıpe: Mitupela i kisim olgeta kaikai i kam. 2

MALOLO: Givim long mi. Mi laik i kukim sampela. Mi hangre nogut tru.

Na MALOLO i kisim na kukim rais na pis. 3 Taim em i kuk i stap yet $i$ singaut long man bilongen:

MALOLO: E, Wanipe, yu baim kom bilong mi o nogat?

Wan1pe: Nogat, mi no baim. Yu no tokim mi olsem.

MALOLO: Ah, yu het diwai. ${ }^{4} \mathrm{Mi}$ tokim yu olsem tasol yu no harim gut.

Wan1pe: 0 Sori, mi het diwai tru. Mi lusim tingting long dispela.

MALOLO: Orait, maski. Kaman olgeta, yumitripela kaikai. 5

Na ol i sindaun na kaikai rais, pis, ti samting.
The two brothers went back to Wanipe's house. His wife, MALOLO, was waiting for them to prepare dinner.

You (pl.) have come huh?

We've brought all the food.

Give it to me. I want to cook

some. I'm terribly hungry.

And MALOLO took it and cooked rice and fish. While she was cooking she called out to her husband:

Heh, Wanipe, did you buy a comb for me or not?

No, I didn't. You didn't tel

me to.

Ah, you blockhead, I told you but you didn't listen properly.

Oh dear, I am a real blockhead, I forgot about it.

All right, nevermind. Come on all of you, let's eat.

And they sit and eat rice, fish, tea and other things. $\left[\right.$ Musik ${ }^{6}$ ]

${ }^{1}$ As a convention in these lessons female names will be written in capital letters.

[footnotes continued overleaf] 
${ }^{2}$ In Pidgin $i \mathrm{kam}$ and $i$ go are used to denote movement away from or towards the speaker respectively. Not only that but it is the conceived locus of the speaker relative to the action that is important and not his actual position. Thus if one asks someone else in Pidgin to take something from a position near the speaker outside a house, say, to a position inside the house he will begin by using the direction marker $i$ go but will change to $i$ kam in describing what happens inside the house, fust as though he had also moved inside. The following sentence will illustrate: Yu kisim kago i go long haus na bringim i kam putim long tebol Take the goods into the house and put them on the table.

3In New Guinea the main meal of the day is eaten in the afternoon. In the traditional village situation this meal is usually cooked over open fires out of doors. 4

${ }^{4}$ New Guinea Pidgin has developed a rich variety of exclamations and epithets for expressing various emotions. Many of these are derived from natural phenomena in a metaphorical way, e.g.

$$
\begin{array}{lll}
\text { stik masis (lit. match stick) a very thin person } \\
\text { wailis } & \text { (11t. wireless) } & \text { a talkative person } \\
\text { muruk } & \text { (lit. cassowary) } & \text { a Zong-legged person }
\end{array}
$$

More of these and other expressions will be introduced later.

${ }^{5}$ Note the difference between the exhortation yumitripela kaikai Zet's (3) (incl.) eatused here and the statement form you should now be familiar with yumitripela i kaikai we(3) (incl.) are eating.

6

The traditional music heard on this tape consists of two love spells. The first one (up to the end of the conversation material) is called Wo-mandep and comes from the Wewak area. It is taken from Sheridan (1958: side 1, track 4, item a) who describes it in the following terms:

A warrior wishes to arrange a meeting with a woman from a nearby village, but is not allowed by local custom to make a direct approach to her. At night-fall, he goes to a tree near the river bank; here there are scores of fireflies. The warrior sings to one of them and if the song is sung correctly, one firefly will move away from the rest and fly off to the hut where the woman is sleeping. She will follow the firefly, trancelike, right to where the warrior is waiting for her.

The second love spell is called Lein Budum and comes from the Busama area in the south-east of the Morobe District. It is also taken from Sheridan (1958: side 1, track 6, item a) who describes it as follows:

A man standing at the river mouth with his fishing spear saw a woman he knew only slightly on the far side of the river bank. He sang this song with the hope that she would be interested in his singing and in turn show an interest in meeting him more often.

\section{USEFUL EXPRESSIONS}

Yu tanim dispela tok long tok Inglis!

Yu bihainim mi!
Translate this into English!

Follow me! 
Yu giaman a?

Nogat, mi no giaman, mi tok tru.

Maski, em samting nating.

\author{
Are you telling a lie? \\ No, I'm not, I'm telling the truth. \\ Forget it, it's not worth worrying \\ about.
}

\section{PRONUNCIATION}

\section{Consonant Sequences}

Consonants that are written together in Pidgin are often pronounced with a very short, and sometimes quite distinct, vowel separating them. Listen to the following related English and Pidgin words and repeat the Pidgin ones.

$\begin{array}{ll}\text { English } & \text { Pidgin } \\ \text { strong } & \text { strong } \\ \text { brother } & \text { brata } \\ \text { store } & \text { stua } \\ \text { clock } & \text { klok } \\ \text { trousers } & \text { trausis } \\ \text { ground } & \text { graun } \\ \text { blood } & \text { blut } \\ \text { screw } & \text { skru } \\ \text { spear } & \text { spial } \\ \text { picture } & \text { piksa }\end{array}$

\section{Stress and Rhythm}

As you listen to Pidgin being spoken by native speakers you will notice that it has a distinct rhythm which is different from that of English. Part of the reason for this is that in Pidgin all syllables tend to be pronounced in approximately the same time, and there is no great difference between stressed and unstressed syliables in terms of loudness and change in pitch as in English. Note also that unstressed vowels in Pidgin are not reduced to a neutral vowel $ə$ (shwa) as they generally are in English.

Exercise 1: Listen to and repeat the stress patterns in the following words of two syllables.

Stress on First syllable

' nambis beach

'skulboi school-boy

'nating invain

'tuhat perspiration
Stress on Last Syllable

na'me l middle

si'kau wallaby

na'ting perhaps

tu'mas very

\footnotetext{
${ }^{I}$ In the Highlands this is pronounced clearly as supia.
} 
Exercise 2: Listen to and repeat the stress patterns of the following words of three syllables.

\begin{tabular}{llll}
\multicolumn{2}{c}{ Stress on First } & Stress on Second & \multicolumn{1}{c}{ Stress on Last } \\
'amamas delighted & am'brela umbrezla & ana'nit underneath \\
'binatang insect & bi'hainim follow & 'baga'rap damage \\
'optin & tin opener & ol'geta all & olo'boi gosh \\
'kokonas coconut & kir'apim begin & 'kora'kum red ant \\
'banisim enclose & luk'autim care for & teke'we clear away
\end{tabular}

Exercise 3: The following pairs of words are generally distinguished in meaning by the stress pattern. Listen carefully to them and repeat each after the instructor.

$\begin{array}{lll}\text { 'hausboi } & \text { (male) servant } & \text { haus 'boi living quarters for } \\ \text { 'hausmeri } & \text { (female) servant } & \text { haus 'meri living quarters for } \\ & & \text { females } \\ \text { 'hauskuk the cook } & \text { haus 'kuk kitchen } \\ \text { 'miksim to mix } & \text { mi 'kisim I got it } \\ \text { 'nating in vain } & \text { na'tingl perhaps }\end{array}$

VOCABULARY EXPANSION EXERCISES

Exercise 1: Simple Substitution

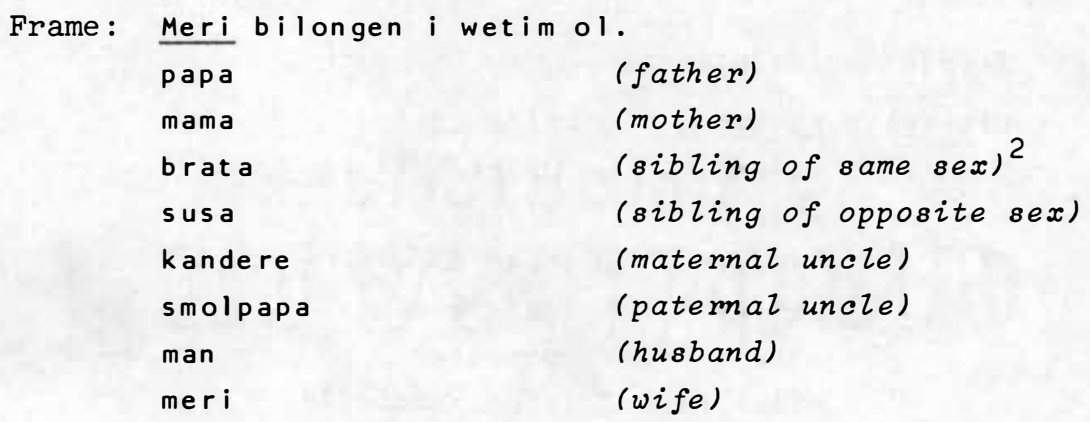

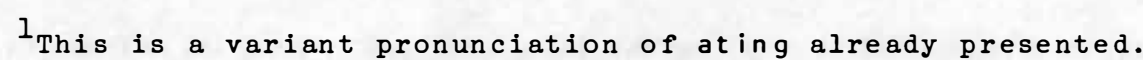

2 Brata and susa should not be confused. A man's brother is his brata while his sister is his susa. However, a woman's brother is her susa while her sister is her brata. 
Exercise 2: Simple Substitution

$\begin{array}{cll}\text { Frame: Yutupela i } & \text { kam ap a } & \\ & \text { las } & \text { (tiagh) } \\ & \text { sekan } & \text { (shake hands) } \\ & \text { singsing } & \text { (dance) } \\ & \text { toktok } & \text { (talk) } \\ & \text { wokabaut } & \text { (walk about) } \\ \text { kam } & \end{array}$

Exercise 3: Simple Substitution

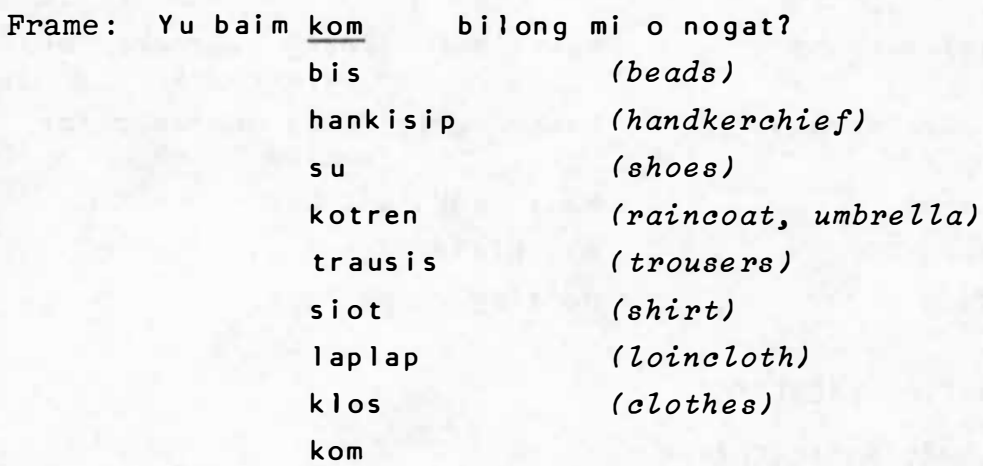

Exercise 4: Simple Substitution

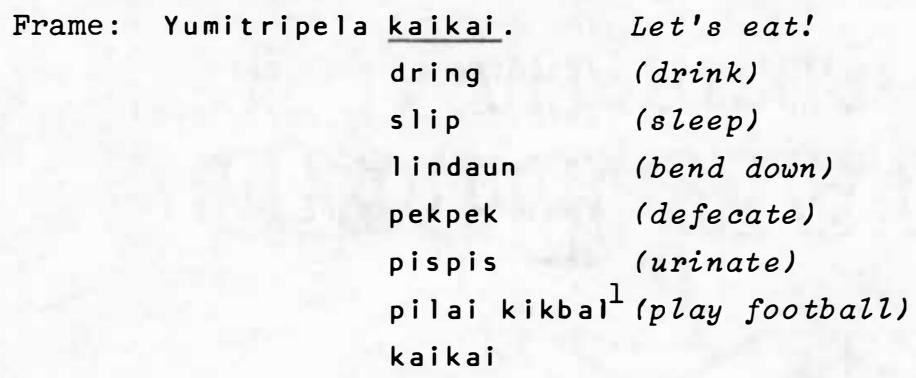

\footnotetext{
${ }^{l}$ Be careful of pilai. Though it means play/joke, if used in reference to maleswith females it means to have sexual intercourse. To be on the safe side always be clear about what is played e.g., football, cards etc. as in the example given.
} 
Exercise 5: Simple Substitution

Frame: Mi hangre nogut tru.

$\begin{array}{ll}\text { sotwin } & \text { (out of breath) } \\ \text { kus } & \text { (cough, sneeze) } \\ \text { sik } & \text { (sick) } \\ \text { kol } & \text { (cold) } \\ \text { hat } & \text { (hot) } \\ \text { kros } & \text { (angry) } \\ \text { hepi } & \text { (happy, pleased) } \\ \text { pulap } & \text { (full, satisfied) } \\ \text { hangre } & \end{array}$

Exercise 6: Simple Substitution

Frame: Mitupela i kisim kaikai i kam.

\begin{tabular}{ll}
\hline kisim pas i kam & (bring letter) \\
karimkago i kam & (carry goods) \\
pulimbokis i kam & (pulz box) \\
bringimsia i kam & (bring chair) \\
bringimsia i go & (take chair) \\
salim pas i go & (send letter) \\
subim tebol i go & (push table) \\
kisim tebol i go & (take table) \\
kisimkaikai i kam & (bring food)
\end{tabular}

\section{GRAMMAR}

\section{1 POSSESSION}

Possession is expressed in Pidgin by placing bilong between the thing possessed and the possessor:

$\begin{array}{cll}\text { Examples: } & \text { haus bilong Wanipe } & \text { Wanipe's house } \\ \text { meri bilong mi } & \text { my wife } \\ \text { man bilongen } & \text { her husband }\end{array}$

Note here, however, the difference between bilongen and bilong em. The former is the normal his, hers, its while the latter translates more as that person's or that thing's. Longen and long em are parallel cases. It is conventional to write bilongen and longen as single words.

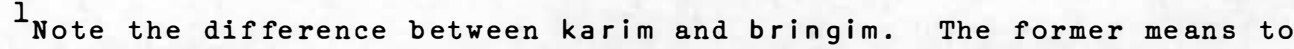
move something to some unspecified place, the latter to some definite one. When $i$ kam and $i$ go are added they distinguish between the idea of bring and take in English. Karim with other adjuncts is used to express other meanings as well, e.g., to be pregnant; menstruate; suffer; bear.
} 
Finally, note that whose is expressed by bilong husat (= of who) in Pidgin.

Examples: E

$$
\text { Em haus bilong dispela That's this man's house. }
$$

man.

Practice Drills

Exencise 1: Simple Substitution

Frame: Yu lukim kandere bilong mi o nogat?

(ol, Dogare, yumi, MALOLO, mi)

\section{Exercise 2: Simple Substitution}

Frame: Susa bilongen i wetim mi.

(mipela, MOREA, yutupela, husat, dispela man, en)

Exercise 3: Change bilong em to bilongen in the following sentences:

1. Mi laik i go antap long haus bilong em. (pause)

2. Wanpela man i stilim kom bilong em. (pause)

3. Papa bilongem i sindaun long opis. (pause)

4. Mi lusim tingting long senis bilongem. (pause)

5. 01 i harim tok Pisin bilongem. (pause)

Evaluation Exercises

Exercise 1: Answer the following questions in Pidgin using the Pidgin cues provided:

1. Em papa bilong husat?

$$
\text { (Wan ipe) }
$$

Em papa bilong Wanipe.

2. Meri bilong husat i kam?

$$
(\mathrm{mi})
$$

Meri bilong mi i kam.

3. Em i haus bilong husat?

(masta na misis)

Em $i$ haus bilong masta na misis.

4. Yupela i harim tok bilong husat? (stuakipa)

Mipela i harim tok bilong stuakipa.

5. Em husat?

(smolpapa bilong MOREA)

Em smolpapa bilong MOREA. 
Exercise 2: Answer the following questions in Pidgin using the English cues provided:

1. Husat i sanap long rot?

(my father)

Papa bilong mi i sanap long rot.

2. Em i givim mani long husat?

(her paternal uncle)

Em i givim mani long smolpapa bilongen.

3. Em husat?

Em kandere bilong dispela meri.

(this native woman's maternal uncle)

4. Husat i brumim ples?

(our (incl.) mother)

Mama bilong yumi i brumim ples.

5. 01 i karim husat i kam?

(MOREA's baby)

01 i karim pikinini bilong MOREA i kam.

\subsection{QUESTIONS}

There are at least three ways of asking questions in Pidgin:

1. by using a (rising) question intonation on sentences which otherwise look like statements, e.g., whereas yu lukim em means you see/saw him, yu lukim em? means did/do you see him?

2. by using the tags a or o nogat on the ends of sentences that otherwise look like statements e.g.,

$$
\begin{array}{ll}
\text { Yu lukim em a? } & \text { You see him don't you? } \\
\text { Yu lukim em o nogat? } & \text { Do you see him or not? }
\end{array}
$$

The a tag expects the answer yes while o nogat expects either the answer yes or no. Both have distinctive intonations associated with them. That for a is similar to (1) above except that it drops away on the tag a.

3. by using an interrogative word or words such as: wanem what, husat who, we where, haumas how much, how many, bilong husat whose, bilong wanem why which have already been introduced.

\section{Presentation Drill}

Listen to and repeat the following different question types after the instructor:

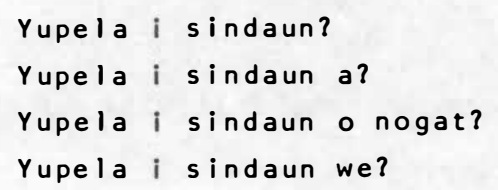


Practice Drills

Exercise 1: Say whether the following utterances are statements or questions :

1. Emtupela $i$ go bek long ples o nogat? (pause)

Question

2. 01 i haitim kago long bus.

(pause)

Statement

3. Misis i salim pas long yu?

(pause)

Question

4. Dispela pikinini i kukim wanem?

(pause)

Question

5. Mitripela i lusim masis long rum.

(pause)

Statement

Exercise 2: Simple Substitution

Frame: 01 i toktok?

(kaikai, wokabaut, sekan, rediim kaikai, toktok)

Exercise 3: Simple Substitution

Frame: Wanpela masta i kam a?

(stap, sindaun, baim pik, salim pas i kam, kam)

\section{Exercise 4: Simple Substitution}

Frame: Yu lap o nogat?

(les, singsing, lukim smolpapa bilong mi, kisimpe, lap)

\section{Exercise 5: Simple Substitution}

Frame: Em i go we?

(mekim wanem, wokim haumas haus, lukim husat, kisim pe we, bilong husat, kros long husat, go we)

Evaluation Exercise

How would you ask someone the following questions in Pidgin:

1. What are you doing?

(pause)

$\mathrm{Yu}$ mekim wanem?

2. Where are my trousers?

(pause)

Trausis bilong $\mathrm{mi}$ i stap we?

[continued overleaf] 
3. Did you see my trousers?

(pause)

Yu lukim trausis bilong mi?

4. Did you see my trousers or not?

(pause)

Yu lukim trausis bilong mi o nogat?

5. Whose trousers are those?

(pause)

Em trausis bilong husat?

6. Do you know?

(pause)

Yu save?

\subsection{NEGATION}

Negative sentences are derived from positive ones by inserting no after the predicative marker $i$, or for the special cases in which no predicative marker occurs, immediately after the subject.

$\begin{array}{lll}\text { Examples: mi kam } & I \text { came } \\ \text { mi no kam } & I \text { didn't come } \\ \text { em i kam } & \text { He came } \\ \text { em i no kam } & \text { He didn't come } \\ \text { yu man } & \text { You're a man } \\ \text { yu no man } & \text { You're not a man }\end{array}$

Practice Drills

Exercise 1: Simple Substitution

Frame: Wanipe i no lap.

(pikinini, yu, dispela meri, ol, yumi, mi, Wanipe)

Exercise 2: Progressive Substitution: In this exercise you will hear two sentences, one negative and one positive. In making the substitutions you will also have to choose the correct pronoun to agree with whatever noun or pronoun is given as cue. For example, if the frame were em $i$ no meri, em $i$ man and the cue was ol, your answer should be ol i no meri, ol i man. Ready?

Frame: $\frac{E m}{" \prime}$

i no meri, $\frac{\text { em }}{\text { " }}$ " man.

"'

Mipela " " "

" " " pis

mipela i man

01

II II

II 1111

"1

11 11

pikinini

ol i man

Yutripela"

11

" " "

11

" " dok

yutripela i man

Em

"1"

"I

II

II II

11

"I meri

em i man

meri 
Evaluation Exercise

Give the negative forms of these sentences:

1. Papa bilongen $i$ ( ) tok tenkyu long mipela. (pause)

2. 01 pik i ( ) kamap long gaden. (pause)

3. Yu ( ) pikininibilong mi. (pause)

4. Wanpela masta $i$ ( ) stap a? (pause)

5. Olgeta meri i ( ) kisim wara i kam. (pause)

6. Mipela $i$ ( ) laik i baimsu. (pause)

7. Emi ( ) rais. (pause)

8. Yupela $i($ ) kam long opis a? (pause)

9. Rupa $i($ ) man bilong Simbu. (pause)

10. $\mathrm{Mi}($ ) man. (pause)

\subsection{NOUNS: SINGULAR AND PLURAL NUMBER}

In Pidgin the number of things spoken about is not indicated in the form of the noun as it generally is in English.l Thus, for example, dok in Pidgin means either dog or dogs in English, depending on context. When necessary, however, Pidgin speakers use the numerals wanpela, tupela, tripela, sampela etc. to specify the precise number of things spoken about though the numeral wanpela one and the pronoun ol they are used to distinguish between singular and plural objects on occasions, e.g., wanpela dok a dog versus ol dok dogs. Note carefully, however, that ol, the plural marker, is to be carefully distinguished from olgeta all in Pidgin. English learners of Pidgin tend to confuse these two.

Examples: wanpela dok $i \mathrm{kam}$

tupela dok i kam

sampela dok i kam

ol dok i kam

olgeta dok i kam a/one dog came

two dogs came

some dogs came

the dogs came

all the dogs came

Practice Drills

Exercise 1: Simple Substitution

Frame: Wanpela pik i go long gaten.

(man, dok, misis, kakaruk, pik)

Exercise 2: Simple Substitution

Frame: 01 wantok i kamap long stua.

(masta, kiap, pikinini, stuakipa, wantok)

\footnotetext{
$l_{\text {There are a few words in Pidgin which are generally regarded as }}$ having implied plurality, e.g., daka betel pepper, morota thatch, su shoes and others. See Mihalic (1971: 12, Section 3.4).
} 
Exercise 3: Progressive Substitution

\begin{tabular}{|c|c|c|c|c|c|}
\hline \multirow[t]{10}{*}{ Frame: } & Luk i m & Wanpe la & man & $\mathbf{i}$ & sanap! \\
\hline & $" 1$ & 11 & pikinini & "I & 11 \\
\hline & 11 & 01 & $" 1$ & 11 & "1 \\
\hline & $" 1$ & $" 1$ & pik & $" 1$ & $" 1$ \\
\hline & 11 & wanpela & $" 1$ & $" 1$ & $" 1$ \\
\hline & $" 1$ & 11 & dok & 11 & $" 1$ \\
\hline & $\because$ & s ampe la & 11 & $" 1$ & 11 \\
\hline & 11 & $" 1$ & pisin & $" 1$ & "I \\
\hline & $" 1$ & wanpela & $" 1$ & $" 1$ & $" 1$ \\
\hline & 11 & 11 & $\operatorname{man}$ & "I & "1 \\
\hline
\end{tabular}

Evaluation Exercises

Exercise 1: Change singular nouns to plural ones and vice versa in these sentences.
1. Wanpela misis i givim senis long mi.
01 misis i givimsenis long mi.
2. 01 pik i stap long ples.
(pause)
Wanpela pik i stap long ples.
3. Mi kisim ol masis.
Mi kisim wanpela masis.
(pause)
4. 01 kiau i stap we?
Wanpela kiau i stap we?
(pause)
5. Yu pasim wanpela buk!
(pause)
Yu pasim ol buk!

Exercise 2: Change the subject nouns to their corresponding pronouns in these sentences:
1. Wanpela meri i sindaun long stua.
(em)
(pause)
2. Olgeta pik i sanap long gaden.
(ol)
(pause)
3. Masta i kam long Mosbi.
(em)
(pause)
4. 01 misis i lukim rum.
(ol)
(pause)
5. Dispela dok $i$ go long rot.
(em)
(pause)
6. Olgeta man i stap long bus.
(ol)
(pause)

Exercise 3: Change ol to olgeta in the following sentences:

1. Dispela man i wokim ol haus.

(pause)

2. Yu putim ol senis long rum.

(pause)

3. Ol pikinini i sindaun long rot.

(pause)

4. Husat i kisim ol pik?

(pause)

5. 01 loliwara i kostim haumas?

(pause) 
Exercise 4: Say in English what the following utterances mean. Treat each where necessary as being in the past tense.

1. 01 i opim olgeta buk!

(pause)

They opened all the books.

2. Wanpela kiap i givim wanpela kiau long mi.

(pause)

A government official gave me an egg.

3. 01 meri i go long Boroko.

(pause)

The women went to Boroko.

4. Yu pasim dispela buk!

(pause)

Close this book!

5. Olgeta pik i go we?

(pause)

Where did all the pigs go?

6. Mi tenkyu long ol kandere bilong $\mathrm{mi}$.

(pause)

I thanked my maternal uncles.

7. Olgeta pikinini i sindaun long rot o nogat?

(pause)

Are all the children sitting on the road or not?

8. Yupela putim olgeta kiau long tebol!

(pause)

you (pl.) put all the eggs on the table.

9. 01 kago i kam?

(pause)

Did the goods come?

10. 01 dok i kaikai olgeta kaikai bilong dispela kakaruk. (pause) The dogs ate all this fowl's food.

\subsection{TRANSITIVE VERBS UNMARKED BY $-\mathrm{im}$}

Some transitive verbs in Pidgin are not marked by the suffix $-i m$. Most of these have to do with bodily functions and have been presented above in the vocabulary expansion exercises. Another common one that has not yet been introduced, however, is gat have.

Examples: mi kaikai rais I eat/ate rice

$$
\text { mi gat rais I have rice }
$$

Note that the verbs pekpek to defecate and pispis to urinate of this set take the objects blut blood and wara water to describe certain prevalent tropical diseases, e.g.

$$
\begin{aligned}
& \text { em i pekpek wara he has diarrhoea } \\
& \text { em i pekpek blut he has dysentery } \\
& \text { em i pekpek win2 he flatulates; pases wind } \\
& \text { em i pispis blut he has blackwater fever }
\end{aligned}
$$

\footnotetext{
${ }^{1}$ Note also the idioms Yu gat tok? Have you got anything to say? and Mi no gat tok I've got nothing to say.
} 
2 Also em i kapupu.

Practice Drill

Simple Substitution

Frame: Dispela man i kaikai kaukau.

(gat planti kago, save tok Pisin, pispis blut, dring bia, pekpek wara, lindaun het bilongen, pekpek blut, kaikai kaukau)

Evaluation Exercise

How would you say the following things in P1dgin? Ready?

1. MOREA has some bread. (pause)

MOREA i gat sampela bret.

2. Her pig ate their rice. (pause) Pik bilongen i kaikai rais bilong ol.

3. Do you have dysentery? (pause) Yu pekpek blut?

4. My dog knows this road. (pause) Dok bilong mi i save dispela rot.

5. The native women bowed their heads. (pause) 01 meri lindaun het bilong ol.

6. Are you (pl.) drinking softdrink or not? (pause) Yupela i dring loliwara o nogat?

7. Alz the dogs have diarrhoea. (pause) 0 lgeta dok i pekpek wara.

8. The European women are pushing the table away. (pause) 01 misis i subim tebol i go.

9. I have blackwater fever. (pause) Mi pispis blut.

10. Are you playing footbalz. (pause)

Yu pilai kikbal? 
TEXT

Listen to the following story about mosquitoes and then see how much of it you can transcribe and/or translate. Here is the text:

Yes, orait. Nau mi laik toktok nau long(?) stori bilong moskito. Olsem moskito em $i$ bin i stap long Sepik Riva. Nau hia long mipela yet $i$ no gat ${ }^{1}$ planti moskito long ples, tasol i gat wanwan ${ }^{2}$ insait long bikpel--bikbus. Nau insait long ples yumi stap longen em $i$ sampela taim moskito i kamap long rabis. Mipela i save troimwe nabaut ol skin tin o sel kokonas, ol empti dram o ol kain samting olsem, nau moskito ol i bin kam--pastaim ${ }^{3}$ binatang $^{4}$ i bin i stap insait ol sel kokonas o dram samting na bihain i mekim moskito. Nau ol i kamap na kaikai mipela. Nau i no planti tumas, i sampela taim, i liklik tasol. Na insait long bus bilong mipela i no planti moskito tumas, em i liklik. Tasol as bilong em em i stap long Sepik Riva, bilong wanem ol i kamap long tais. ${ }^{5}$ I bikpela tais moa long Sepik Riva. Em i as bilong moskito em i stap long Sepik. Nau ating em tasol long liklik stori bilong moskito nau.

[Playing time: 1.5 minutes]

ENGLISH TRANSLATION :

yes, all right. Now I'm going to (or want--depending on how laik is being used here) talk about mosquitoes. It's like this. Mosquitoes have been living in the Sepik River (area). (But) now there are not many around here (lit. our area), although (lit. but) there are a few in the jungle. Around this area (lit. in the area in which we live) mosquitoes occasionally breed (lit. originate) in rubbish (lying about). We (excl.) are always throwing empty tins or coconut shells, empty drums or various other things like that around about and mosquitoes come--at first wrigglers live in the coconut shells or drums and other things and then they turn into mosquitoes. Then they come (2it. arrive) and bite (lit. eat) us. Now there are not many, (only) sometimes (do they come), only a few. And inside our dense bush there are not many mosquitoes, (only) a few. But you will really find them in the sepik River (area) because they originate in the swamps. There are very big swamps about the Sepik River. That's their homeland, the sepik. Well I guess that's all there is to this short story about mosquitoes.

\footnotetext{
$1_{i}$ no gat $=$ there is/are not

2 i gat wanwan $=$ there are a few
} 


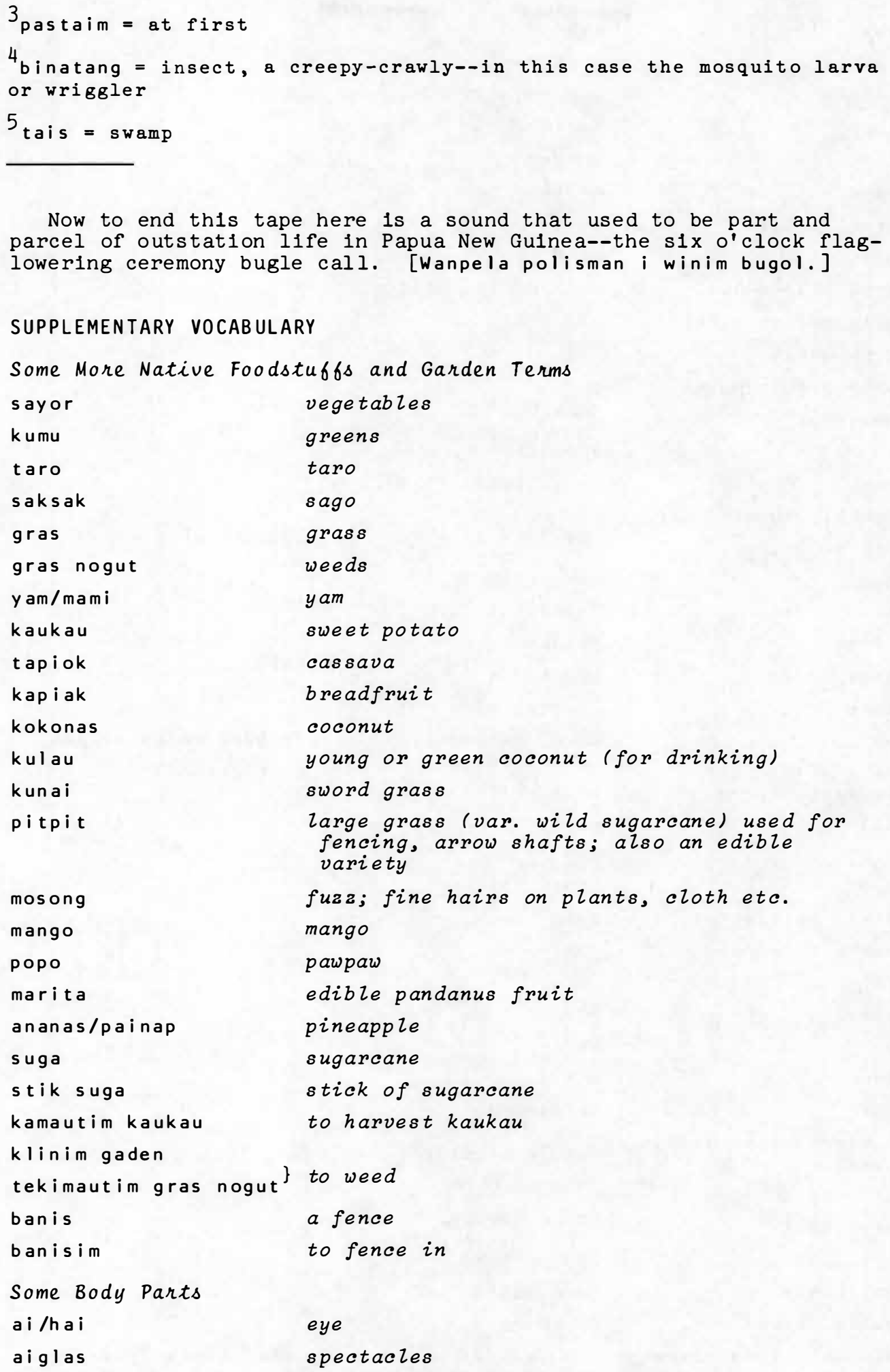

Now to end this tape here is a sound that used to be part and parcel of outstation life in Papua New Guinea--the six o'clock flaglowering ceremony bugle call. [Wanpela polisman i winim bugol.]

\section{SUPPLEMENTARY VOCABULARY}

Some More Native Foodstuffs and Garden Terms 


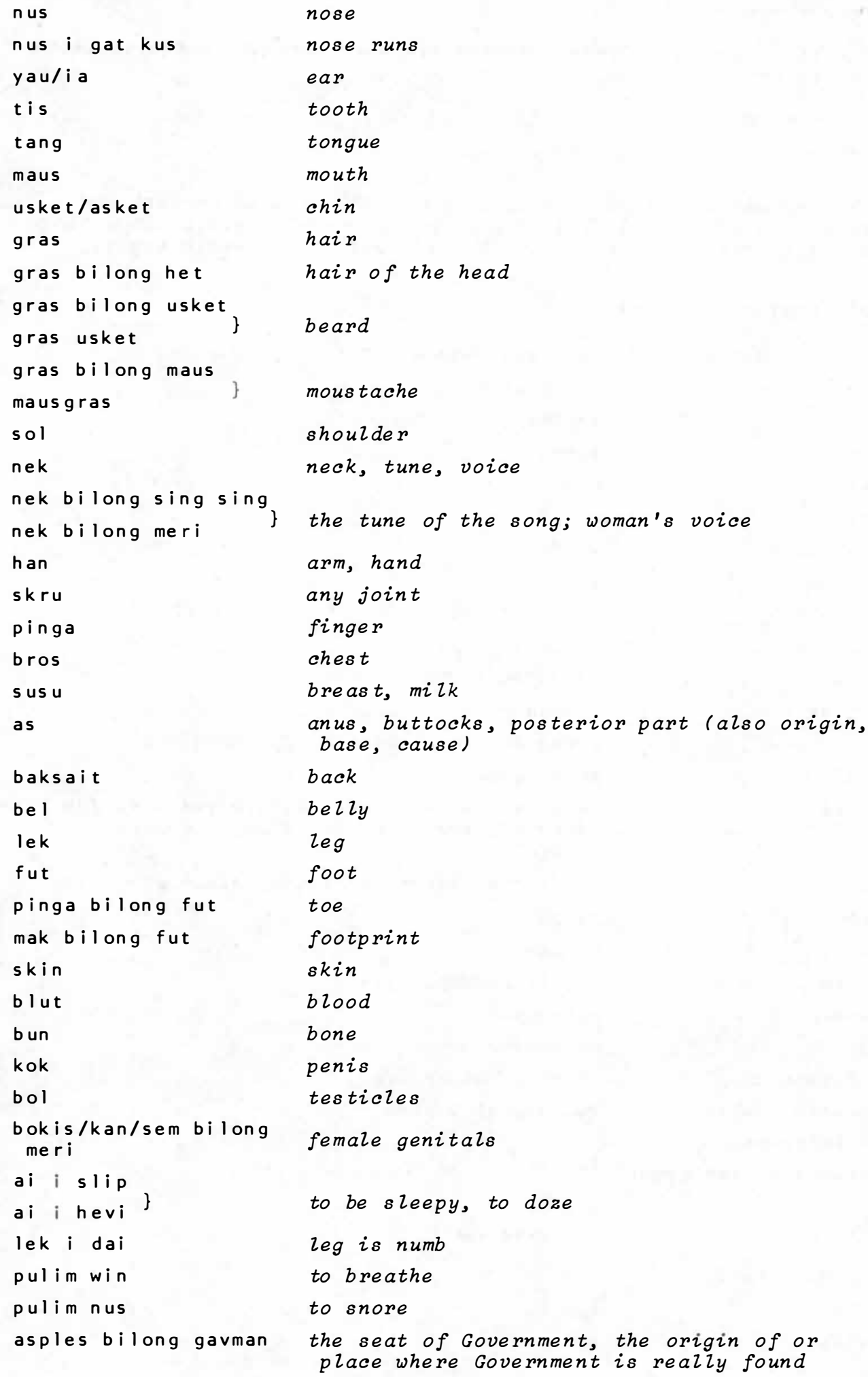




\section{CLASSROOM EXERCISES}

1. Revision of the unit but with special attention to the following: (a) difference between the hortative let us and the statement we are (doing such and such). See footnote 5 to the Conversation and Vocabulary Expansion Exerc1se No. 6.

(b) difference between tokim to tell, tok to say, tok tok to converse, talk and toktok long to talk about (something), to talk to someone.

(c) the direction markers $i$ go and $i \mathrm{kam}$. See footnote 2 to the Conversation.

2. Conversation with native speaker about his famlly, his $11 \mathrm{fe}$ and job. Write up a summary account of this in P1dgin and/or draw the family tree for text 6 in Unit 16.

3. Repeat the following sentences in the way indicated in brackets after each:

1. Misis i salim pas long dispela man. (As a quest1on that w1ll be answered yes; as a command to misis; so as to Indicate that the person referred to is my father; as a negative statement; as a question that will be answered perhaps).

11. Em $i$ go we? (As a statement telling of the person's destinat1on; so as to indicate that three people were involved; askIng if the person went to the market or not).

111. 01 meri $i$ sindaun long rot. (As a negat1ve statement; as a question asking who; as a question asking what the women were dolng; as a statement saying the women blocked the road).

4. Name all the native foods you can think of (or that appear in a set of pictures shown).

5. Draw a st1ck-man and label the following parts: yau, gras usket, sol, skrubilong lek, baksait, as, han, mausgras, bros. 


\section{UNIT 4}

\section{CONVERSATION}

\section{Long Nait}

Long nait Wanipe tupela MALOLO ${ }^{l}$ During the night Wanipe and MALOLO

i sindaun toktok wantaim Dogare. are sitting down talking together with Dogare.

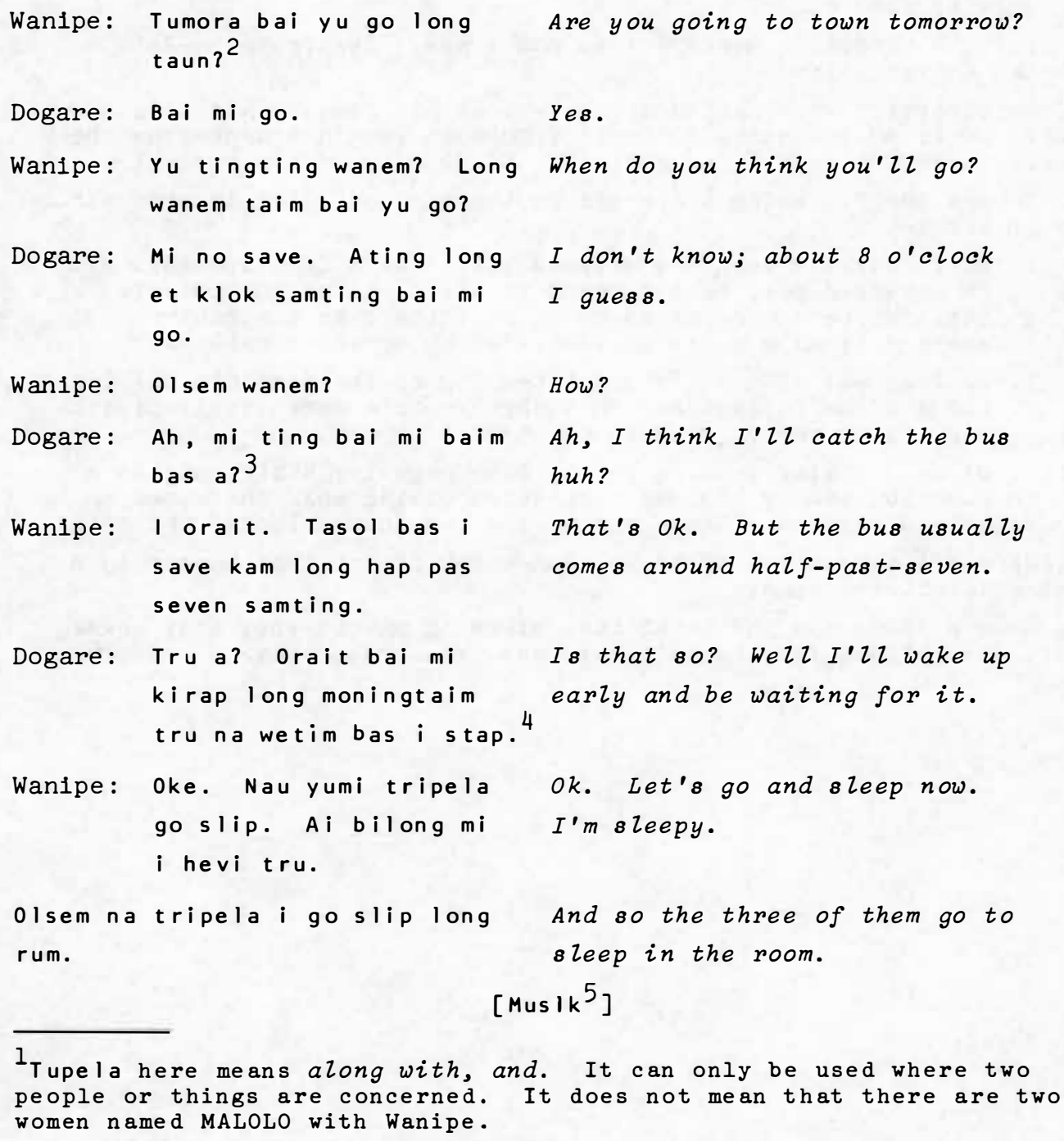

${ }^{1}$ Tupela here means along with, and. It can only be used where two people or things are concerned. It does not mean that there are two women named MALOLO with Wanipe. 
2 The bai is not necessary to indicate futurity in this sentence since the adverb tumora is sufficient (cf. Unit 1, Section 1.2). It is introduced here merely to help the learner associate bai with futurity.

3 Excluding taxis (taksi) there is a variety of vehicles in New Guinea licenced to carry passengers (pasindia). These include ordinary buses (bas) minibuses (liklik bas) and generally open trucks of various sizes with wooden benches as seats for passengers, for example, trak truck, ka car, hapka or haptrak utility, and trak i gat wilka or semitrela semi-trailer. These normally operate on roads out of main centres, and carry cargo (garden produce, personal luggage) as well, for a fee. All such vehicles display P.M.V. (piemvi) identification notices. Finally, note the difference between the idioms baim bas to pay for a passage or journey, and the more normal use of baim in baim wanpela bas to purchase a bus.

4 stap in the expression wetim bas $i$ stap indicates continuing action and refers to the wetim and not bas. Thus wetim bas i stap means ( $I^{\prime} 2 l$ be) awaiting the bus. I stap will be introduced and drilled in the coming units.

5 The traditional music heard on this tape is of bamboo flutes from the Chimbu District. In this example the flutes are played antiphonally by a pair of players as an invitation to a pig feast. The recording comes from Sheridan (1958: side 2, track 1, item g). [Tupela man bilong Simbu i winim mambu.]

\section{USEFUL EXPRESSIONS}

OIsem wanem ol i tok 'What's the time?' long tok Pisin?

01 i tok, "Em i wanem taim nau?"

Mi no save, hanwas bilong mi i da i . 1

Mi no save, hanwas bilong mi i ran kranki.

Mi no save, hanwas bilong mi i ran kwik.

Mi no save, hanwas bilong mi i ran slo.

Yu kam bipotaim a?

Yu kam bihaintiam a?
How does one say 'What's the time?' in Pidgin?

One says, "What's the time now?"

I don't know, my watch's stopped.

I don't know, my watch doesn't keep good time.

I don't know, my watch is fast.

I don't know, my watch is slow.

You're early huh?

You're late huh?

${ }^{1}$ i dai is usually said indai and is often written that way. Note also the important difference between the two verbs kilim to strike, wound and kilim i dai to kizl, murder. 
VOCABULARY EXPANSION EXERCISES

Exercise 1: Simple Substitution

Frame: Long nait Wanipe tupela MALOLO i sindaun toktok wantaim

\begin{tabular}{|c|c|}
\hline san & (daytime) \\
\hline de bilong wok & (workday) \\
\hline de bilong malolo & (day-off, holiday, \\
\hline wiken & (weekend) \\
\hline taim bilong malolo & (free time, recess) \\
\hline apinun & $\begin{array}{l}\text { (afternoon) } \\
\text { (mornina) }\end{array}$ \\
\hline $\begin{array}{l}\text { moningtaim } \\
\text { taim bilong kaikai }\end{array}$ & $\begin{array}{l}\text { (morning) } \\
\text { (meal time) }\end{array}$ \\
\hline & \\
\hline
\end{tabular}

Exercise 2: Simple Substitution

Frame: Long wanem taim bai yu go?

$\begin{array}{ll}\text { de } & \text { (day) } \\ \text { wik } & \text { (week) } \\ \text { mun } & \text { (month) } \\ \text { yia } & \text { (year) } \\ \text { krismas } & \text { (Christmas) } \\ \text { de bilong wok } & \text { (workday) } \\ \text { taim } & \end{array}$

Exercise 3: Simple Substitution

Frame: Bai yu go olsem wanem?

$\begin{array}{ll}\begin{array}{l}\text { kambek } \\ \text { katim diwail }\end{array} & \begin{array}{l}\text { (return) } \\ \text { (cut the tree) } \\ \text { lainim tok ples }\end{array} \\ \text { lukautimpikinini } & \text { (take care of the child) } \\ \text { senisim dispela } & \text { (change this) } \\ \text { skulim ol long tok } & \text { (teach them Pidgin) } \\ \text { Pisin } & \text { (shoot the dog) } \\ \text { sutim dok } & \text { (overturn the truck) } \\ \text { kapsitim trak } & \end{array}$

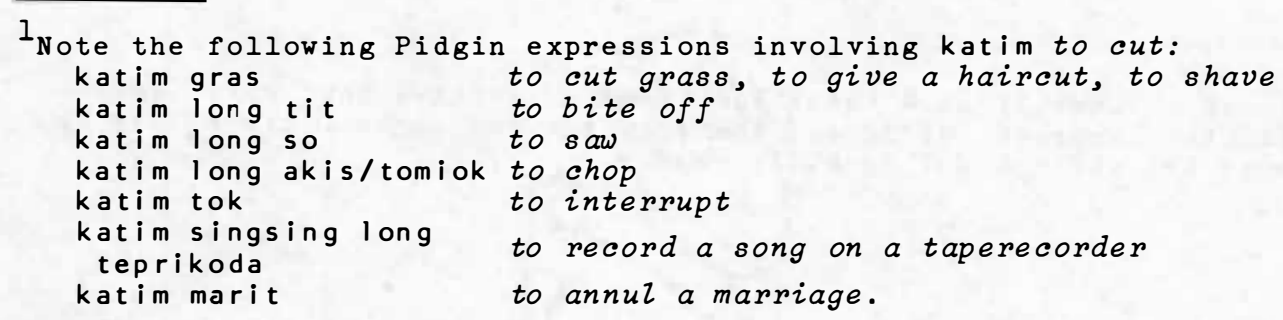


${ }^{2}$ Sutim is pronounced siutim by many Pidgin speakers.

Exercise 4: Simple Substitution

Frame: Mi ting bai mi baim bas a?

$\begin{array}{ll}\text { wokabaut long bikrot } & \begin{array}{l}\text { (walk along the main } \\ \text { road) }\end{array} \\ \begin{array}{ll}\text { go long wilwil } & \text { (ride on abicycle) } \\ \text { baimbalus } & \text { (buy an air-ticket) } \\ \text { kam long balus } & \text { (come by plane) } \\ \text { go long kanu } & \text { (goby canoe) } \\ \text { baim pasindia trak } & \begin{array}{l}\text { (catch a passenger } \\ \text { vehicle) }\end{array} \\ \text { sindaun hia } & \text { (sithere) } \\ \text { baimbas } & \end{array}\end{array}$

Exercise 5: Simple Substitution

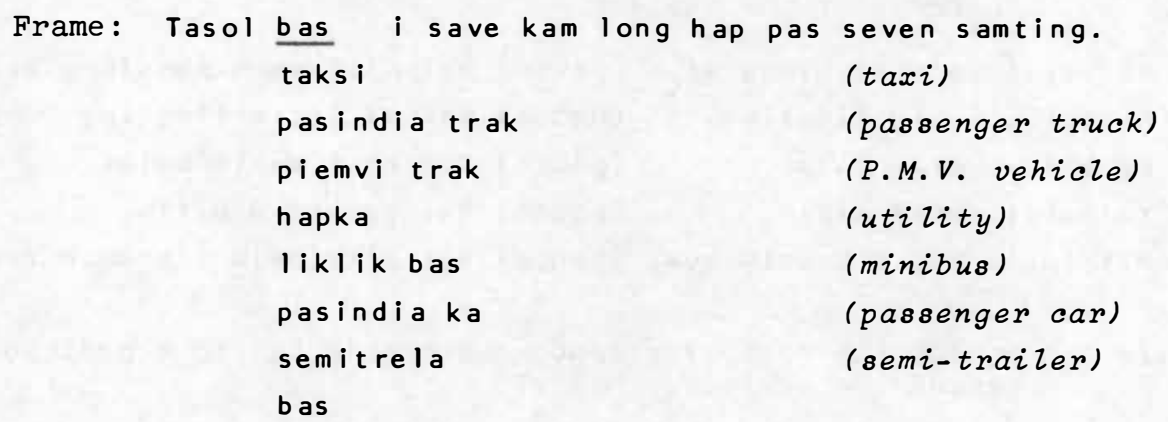

\subsection{BAI + VERB : FUTURE TENSE}

Actions which are to be performed at some time in the future are Indicated in P1dgin by placing bai elther before or after the subject. For short subjects (like pronouns or single words) bai tends to come before the subject; for longer subjects 1 t tends to follow. When $1 t$ comes after the subject, however, bai must always be followed by the predicate marker $\mathbf{i}$ otherwise the normal rules for the appearance of i apply as so far discussed.

Examples: Bai mi go long taun.

Mi bai i go long taun. ' I' 22 go to town.

Bai em i go long taun.

Em bai i go long taun. H $H e^{\prime} Z 2$ go to town.

Dispela man bai i go This man will go to

long taun. town. 
Practice Drills

Exercise 1: Simple Substitution

Frame: Bai mipela i painim wok.

(ol, mi, emtupela, mitripela, yumi, yu, mipela)

\section{Exercise 2: Simple Substitution}

Frame: Mipela bai i painim wok.

(em, mi, yumitupela, yu, emtripela, ol, mipela)

\section{Exercise 3: Simple Substitution}

Frame: Wantok bilongen bai i skulimmi long tok lnglis.

(dispela pikinini, smolpapa bilong mi, brata bilong mitupela, mama bilong misis, wantok bilongen)

Exercise 4: Repeat the following sentences moving bai to a position in front of the subject.

1. 01 bai i soim pas long mi. (pause) Bai ol i soim pas long mi.

2. Mi bai i lusim tingting. (pause) Bai mi lusim tingting.

3. Em bai i wetimbalus. (pause) Bai em i wetimbalus.

4. Yubai sutimpisin. (pause) Bai yu sutimpisin.

5. Mitripela bai i brumim rum. (pause) Bai mitripela i brumim rum.

Exercise 5: Repeat the following sentences moving bai to a position behind the subject. Ready?

1. Bai emtupela i dring bia. (pause) Emtupela bai i dring bia.

2. Bai mi toktok.

(pause) Mi bai i toktok.

3. Bai ol i pekpek blut.

(pause) 01 bai i pekpek blut.

4. Bai yumitupela i askim masta long pe.

(pause) Yumitupela bai i askim masta long pe.

5. Bai yu wokabaut long bikrot.

(pause) Yu bai i wokabaut long bikrot.

\section{Evaluation Exercise}

Say what the following sentences mean in English.

1. Bai masta i putim ol hanwas long bokis. (pause)

The European man will put the watches in the box.

2. Kandere bilong emtripela bai i tokim yu. (pause)

Those(3) fellows' maternal uncle will tell you.

3. Narapela hankisip bai i kostim haumas? (pause)

How much will another handkerchief cost? 
4. Pikinini bilong dispela meri bal i les. (pause)

This native woman's child will be tired.

5. Planti kakaruk bai i kaikai rais bilong yu. (pause)

Plenty of fowls wizl eat your rice.

\subsection{DAYS AND DATES}

In Pldgin the names of the days of the week and of the months of the year are as in English except for Tuesday, Wednesday and Thursday which are transliterations of English two-day, three-day and four-day respectively. Here is the complete set:

\begin{tabular}{llll}
\multicolumn{2}{c}{ Days } & (de) & \multicolumn{2}{c}{ Months (mun) } \\
Monday & Mande & January & Janueri \\
Tuesday & Tunde & February & Februeri \\
Wednesday & Trinde & March & Mas \\
Thursday & Fonde & Apriz & Epril \\
Friday & Fraide & May & Me \\
Saturday & Sarere & June & Jun \\
Sunday & Sande & July & Julai \\
& & August & Ogas \\
& & September & Septemba \\
& & October & Oktoba \\
& & November & Novemba \\
& & December & Desemba
\end{tabular}

Dates are formed from these and the numerals already learned, in the following way: 1
1st August
de namba wan bilong mun ogas
16 th March
de namba wanpela ten sikis bilong mun Mas
on 21 st June
long de namba tupela ten wan bilong mun Jun
Today is the
fifth of May
Tude $i$ de namba faiv bilong mun Me.

Years are sald as In English, e.g.,

1913

1930

1972

Today is the 30th March, 1972

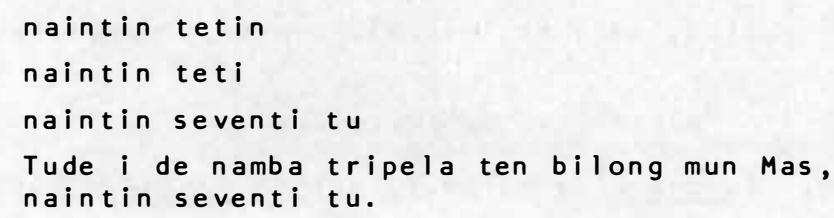

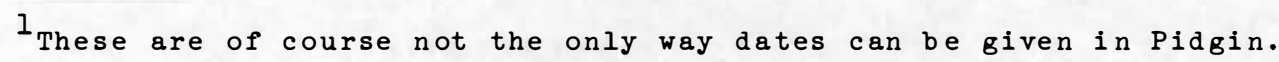


Presentation Drills

Exercise 1: Look at the listing of days and months given in your book and repeat their names after the instructor. Each is sald only once. Ready?

The Days: Mande, Tunde, Trinde, Fonde, Fraide, Sarere, Sande.

The Months: Janueri, Februeri, Mas, Epril, Me, Jun, Julai, Ogas, Septemba, Oktoba, Novemba, Desemba.

Exercise 2: Look at your book again and repeat the following dates after the instructor. Ready?

5 th Marah de namba faiv bilong mun Mas

26 th September, 1969 de namba tupela ten sikis bilong mun Septemba, nalntin sikisti nain

10th May, 1823 de namba ten bilong mun Me, naintin twenti

$\operatorname{tr} \mathbf{i}$

1st July, 1930 de namba wan bilong mun Julai, naintin teti

11 th November, 1813 de namba wanpela ten wan bilong mun Novemba, naintin tetin

Practice Drills

Exercise 1: Simple Substitution

Frame: Bai em i kam long mun Janueri.

(Epril, Ogas, Mas, Februeri, Me, Janueri)

\section{Exercise 2: Simple Substitution}

Frame: Yu go wetim balus long Mande.

(Trinde, Sarere, Fonde, Tunde, Mande)

Exercise 3: Simple Substitution

Frame: Tude $i$ de namba sikis bilong mun Mas.

(ten, wan, et, wanpela ten tu, tupela ten foa, sikis)

\section{Exercise 4: Progressive Substitution}

Frame: Tumora i de namba tu bilong mun Me.

\begin{tabular}{|c|c|c|c|c|c|c|c|}
\hline 11 & $" 1$ & $" 1$ & 11 & "I & 11 & mun & Ogas. \\
\hline Tude & $" 1$ & 11 & 11 & "1 & $" 1$ & " & " (Today) \\
\hline " & $" 1$ & 11 & 11 & $" 1$ & $" 1$ & mun & Janueri. \\
\hline Asde & $" 1$ & $" 1$ & $" 1$ & $" 1$ & $" 1$ & $" 1$ & " (Yesterday) \\
\hline$\|$ & "1 & $" 1$ & $" 1$ & 11 & 11 & mun & Desemba. \\
\hline
\end{tabular}


Asde i de namba tu bilong mun Desemba.

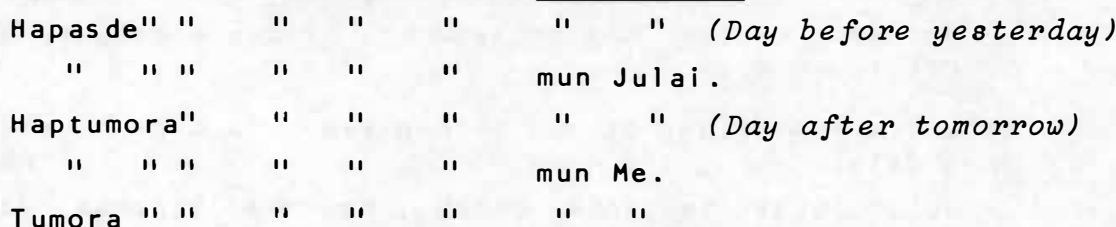

\section{Evaluation Exercises}

Exercise 1: Open your book and read the following days and dates from 1t. Begin after each set is 1dentifled by the instructor. You have a few seconds in which to answer. ${ }^{1}$ Ready?

Set 1: Tuesday, Sunday, Thursday, Monday, Saturday, Wednesday.

Set 2: June, Apriz, October, July, January, May.

Set 3: 1st March, 3rd July, 15 th February.

Set 4: 22.3.1964; 11.5.1930; 8.10.1847.

Exercise 2: Answer the following questions using the cues provided. G1ve complete sentences.

1. Yu gat haumas krismas? ${ }^{2}$ (22) (pause)

Mi gat tupela ten tu krismas.

2. Yu kolim nem bilong ol de bilong wik! Yu bigin long Sarere.

(Sarere, Sande, Mande, Tunde, Trinde, Fonde, Fraide)

3. Long wanem mun ol i senisim dispela. (December)

01 i senisim dispela long mun Desemba.

4. Yupela i gat haumas krismas? (35) (pause)

Mipela i gat tripela ten faiv krismas.

\footnotetext{
1 The corresponding answers are:

Set 1: Tunde, Sande, Fonde, Mande, Sarere, Trinde.

Set 2: Jun, Epril, Oktoba, Julai, Janueri, Me.

Set 3: De namba wan bilong mun Mas; de namba tri bilong mun Julai; de namba wanpela ten faiv bilong mun Februeri.

Set 4: De namba tupela ten tu bilong mun Mas, naintin sikisti foa; de namba wanpela ten wan bilong mun Me, naintin teti; de namba et bilong mun Oktoba, etin foti seven.

2 This means How old are you?
} 
5. Long wanem de bai em i kambek? (August 3rd, 1982) (pause) Bai em i kambek long de nama tri bilong mun ogas, naintin e t i tu.

6. Yu kolim nem bilong ol mun bilong yia. Yu bigin long Julai.

Julai, Ogas, Septemba, Oktoba, Novemba, Desemba, Janueri, Februeri, Mas, Epril, Me, Jun.

\section{Construction Exercise}

Take a plece of scrap paper and draw a calendar for the month of Apr1l, 1932, showing the names of the days of the week, and given that Sarere i de namba tupela ten seven bilong mun Mas, naintin teti tu. Then put a ring around the following:

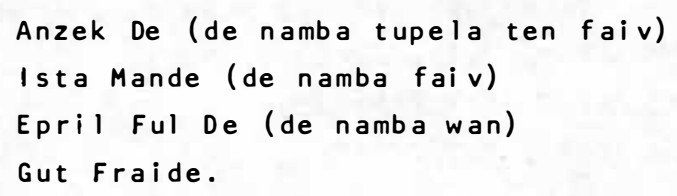

Check your answer against that given in your book. ${ }^{1}$

\subsection{TIME}

Each 24-hour day is divided up in the following way in P1dgin:

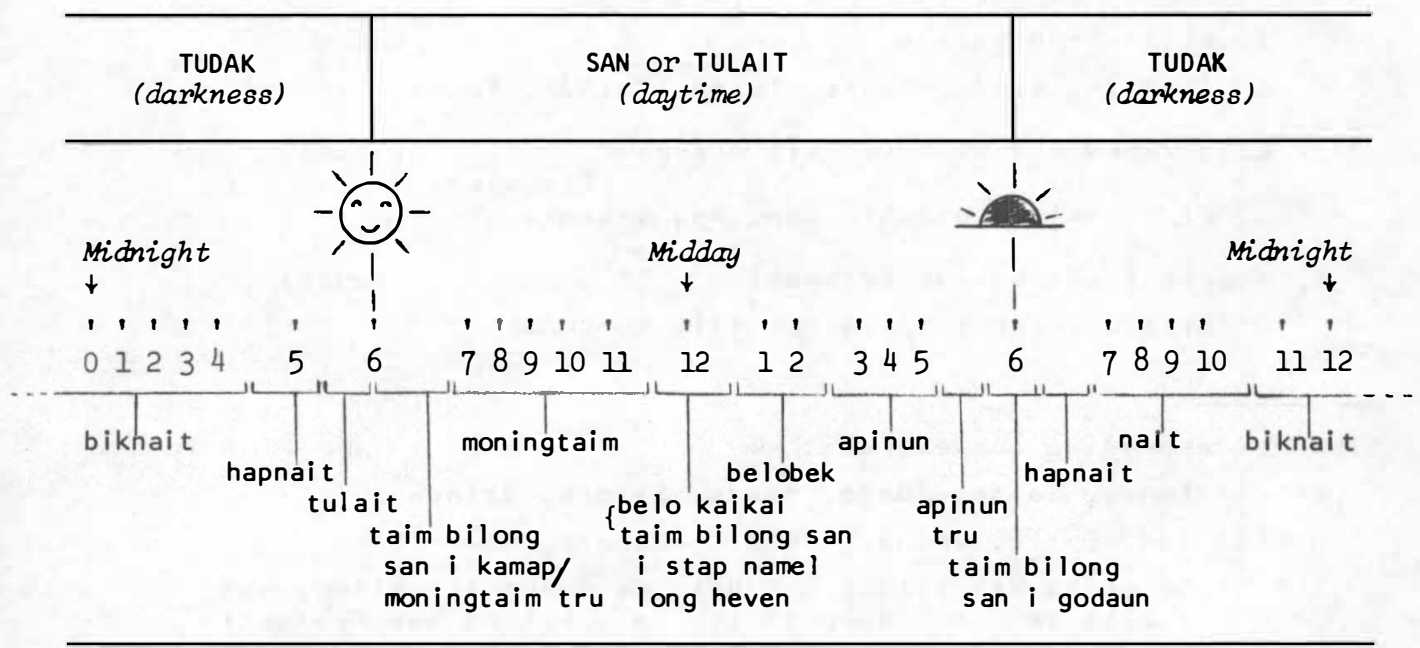

${ }^{1}$ Answer to Construction Exercise in Section 4.2:

Epril, 1932

\begin{tabular}{lrrrrr}
\hline Sande & 4 & 11 & 18 & 25 \\
Mande & 5 & 12 & 19 & 26 \\
Tunde & 6 & 13 & 20 & 27 \\
Trinde & 7 & 14 & 21 & 28 \\
Fonde & 1 & 8 & 15 & 22 & 29 \\
Fraide & 2 & 9 & 16 & 23 & 30 \\
Sarere & 3 & 10 & 17 & 24 & \\
\hline
\end{tabular}


However, as wristlet watches (hanwas) and clocks ( $k$ lok) become more common and radio stations make increasing reference to more precise time English time-telling habits are being taken over into Pidgin. Thus instead of saying yu kam bihain long tulait tru You come after 6 o'clock a.m. more sophisticated speakers say yu kam long sikis klok stret You come at exactly six o'clock or yu kam long faiv minit bipo long sikis klok You come at 5 to 6 or yu kam long faiv minit bihain long sikis klok You come at 5 past 6 . In the following exercises both systems will be presented. Before then, however, note the following :

1. The adverbs stret exactly and samting about, approximately modify the said time, e.g.,
long sikis klok stret
at exactly 6 o'clock
long sikis klok samting
at about 6 o'clock

2. Notions like the end of the week, or month etc. are expressed in Pidgin by the verb pinis to finish, e.g.

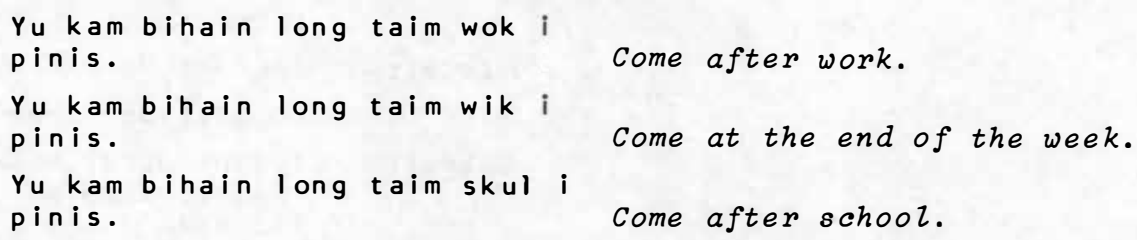

Come after school.

3. The eve and the night of the day named are distinguished in the following way:
(on) Sunday night
= (long) Sande long nait
(on) the eve before sunday
$=$ (long) nait bllong Sande

Note especially Krismas nait which means Christmas Eve and not Christmas Night.

4. There is no single word for when in Pidgin. This is expressed by the phrase long wanem + some time word like taim, de, mun etc. which corresponds to the English at what/which time, day, month, etc.

This phrase can occur at the beginning or end of the question sentence. Answers to this question are of similar form except that there are a few words like tumora, asde, tude, hapasde, haptumora, bipo, baimbai which are not preceded by long.

The following exercises are designed to drill these aspects of Pidgin time. 1

\section{Presentation Drill}

Exercise 1: Repeat the following items after the instructor while identifying the time referred to in the chart given in your book. The instructor will read from left to right:

Frame: Mipela i sindaun toktok long biknait. (during the dead

$\begin{array}{ll}\text { hapnait } & \text { of night) } \\ \text { tulait } & \text { (dawn, daybreak) }\end{array}$

lFor further ideas on Pidgin time the student might also consult Mihalic (1971) under sande. What is said there also now applies pretty well to wiken in Pidgin. 
Mipela i sindaun toktok long tulait.

\begin{tabular}{|c|c|}
\hline moningtaim & $\begin{array}{l}\operatorname{tru}{ }^{l}(j u s t \text { after } \\
\text { sunrise) }\end{array}$ \\
\hline moningtaim & (morning) \\
\hline belo kaikai & $\begin{array}{l}\text { (noon; knock-off } \\
\text { bell for lunch) }\end{array}$ \\
\hline $\begin{array}{l}\text { taim bilong } \\
\text { long heven }\end{array}$ & $\begin{array}{l}\text { san i s tap name l } \\
(m i d d a y)\end{array}$ \\
\hline be lobek & $\begin{array}{l}\text { (1-2 p.m.; return } \\
\text { to work time) }\end{array}$ \\
\hline apinun & (afternoon) \\
\hline $\begin{array}{l}\text { apinun tru } \\
\text { taim bilong }\end{array}$ & $\begin{array}{l}\text { ( Late afternoon) } \\
\text { san i godaun } \\
\text { (sunset) }\end{array}$ \\
\hline hapnait & (almost dark) \\
\hline nait & (night, darkness) \\
\hline biknait & $\begin{array}{l}\text { (pitch dark, mid- } \\
\text { night, dead of } \\
\text { night) }\end{array}$ \\
\hline
\end{tabular}

Exercise 2: Read of the following times from your book after the instructor:

Set 1: 8 o'clock

$\frac{3}{2}$ past 10

1 o'clock sharp

about $\frac{1}{2}$ past 4

7 o'clock sharp

Set 2: at 2 o'clock sharp

before $\frac{1}{2}$ past 9

after 12 o'clock

before 11 o'clock

at about $\frac{1}{2}$ past 6

Set 3: 10 minutes past 8

5 minutes to 10

25 minutes past?

25 minutes to 11 et $k$ lok

hap pas ten

wan klok stret

hap pas foa samting

seven klok stret

long tu klok stret

bipo long hap pas nain

bihain long twelv klok

bipo long eleven klok

long hap pas sikis samting

ten minit bihain long etklok

faiv minit bipo long ten klok

tupela ten faiv minit bihain long seven klok

tupela ten faiv minit bipo long eleven $k l o k$

\footnotetext{
${ }^{1}$ Note the use of tru very in these expressions--in the first case it translates as early while in the second as late. One can also say tulait tru meaning late dawn--just before sunrise though the time sequence for tulait and tulait tru is very short and therefore not as clearly defined as moningtaim tru and apinun tru.
} 
Practice Drills

Exercise 1: Simple Substitution

Frame: Hanwas bilong mi i dai long sikis klok.

(longhap pas ten, long tu klok stret, bihain long twelv klok, long faiv minit bihain long et klok, long sikis klok)

Exercise 2: Answer the following questions using the Pldgin cues provided. Although each question is the same your answer should mimlc the way the question is asked, so that if long wanem taim appears at the beginning of the question then your answer should begin with the corresponding time words, and similarly if long wanem taim appears at the end of the question. Ready?

1. Long wanem taim em i baim wilwil long stua?

(long hap pas foa samting) (pause)

Long hap pas foa samting em i baim wilwil long stua.

2. Long wanem taim em i baim wilwil long stua?

(long wan klok stret)

(pause)

Long wan klok stret em i baim wilwil long stua.

3. Em i baim wilwil long stua long wanem taim?

(bipo long foa klok)

(pause)

Em i baim wilwil long stua bipo long foa klok.

4. Long wanem taim em i baim wilwil long stua?

(long tupela ten minit bihain long tu klok) (pause)

Long tupela ten minit bihain long tu klok em i baim wilwil

long stua.

5. Em i baim wilwil long stua long wanem taim?

(long eleven klok samting long nait) (pause)

Em i baim wilwil long stua long eleven klok samting long nait.

\section{Evaluation Exercises}

Exercise 1: Open your book and read of the following parts of the day In Pidgin.l Ready? Go:

dawn; midday (referring to the position of the sun); sundown;

midnight; just after sunrise; almost dark; morning; 1-2

o'clock in the afternoon.

ltulait; taim bilong san i stap namel long heven; taimbilong san i godaun; biknait; moningtaim tru; hapnait; moningtaim; belobek. 
Exercise 2: Read of the following times in Pldgin. ${ }^{1}$ Ready? Go:

11 o'clock; 8 o'clock sharp; about 6 o'clock; $\frac{1}{2}$ past 2 ;

20 minutes past five sharp; at about 11 p.m.; before 5 minutes to 10 .

Exercise 3: Answer the following questions using the cues provided. Ready?

1. Long wanem taim bai em i kisim kago i go?

( 4 o'clock sharp)
Long foa klok stret bai em i kisimkago i go.

2. Long wanem de yupela i lukim dispela meri long bung?

(We dnesday)

Long Trinde mipela i lukim dispela meri long bung.

3. Long wanem de bai ol i kam?

(day after tomorrow)

(pause)

Haptumora bai ol i kam.

4. Long wanem taim bai yu go long taun?

(about 8 o'clock I guess)

(pause)

Ating long et klok samting bai mi go long taun.

5. Long wanem de ol i kirap long slip?

(the day before yesterday)

(pause)

Hapasde ol i kirap long slip.

\subsection{SAVE + VERB : HABITUAL ACTIONS}

Habltual actions are expressed in P1dgin by placing save before the verb, e.g.,

Tasol bas i save kam long hap But the bus normally/usually

pas seven samting

comes around about $\frac{1}{2}$ past 7

01 manmeri bilong Papua Niu

Papua-New Guineans eat sweet-

Gini i save kaikai kaukau.

potato.

Tasol ol Yuropen i save

kaikai bulmakau.

But Europeans eat beef.

Mipela i no save kaikai

bulmakau.

We don't (customarily) eat beef.

Note that in negative sentences like the last one the negative marker no comes after the predicat1ve marker $i$ and before $s$ ave.

leleven klok; et klok stret; sikis klok samting; hap pas tu; tupela ten minit bihain long faiv klok stret; long eleven klok samt lng long nait; bipo long faiv minit bipo long ten klok. 
Finally sentences of the form given above can be transformed into ones related in meaning using bilong to denote a characteristic habit of a person or thing. Compare the following:

0ltaim oltain em i save kaikai He/ShelIt habitually eats everyolgeta samting. thing all the time.

Em i man bilong kaikai olgeta He/She/It is a "garbage can". samting.

01 taim oltaim dispela meri i This woman is not a skite at no save hambak. any time.

Dispela i no meri bilong This woman's not a skite.

hambak.

Oltaim oltaim ol dispela pik i These pigs are always breaking save brukim banis. fences.

01 dispela i pik bilong brukim These pigs are fence-breakers. ban is.

01 taim oltaim mi save stap long nambis/maunten. I live (always) on the coast/in Mi man bilong nambis/maunten. the mountains. I'm a coastal person/a man of the mountains.

Some very common forms in this veln are:

man bilong giaman
man bilong kaikai
man bilong pait
man bilong save
man bilong toktok
man bilong wok
man bilong lotu

a liar

a glutton an aggressive person, a warrior a learned man, clever man

a talkative person

a good worker, an industrious person man bilong lotu a church goer

For others and compounds w1th man see M1hal1c (1971:128-9).

Practice Drills

Exercise 1: Simple Substitution

Frame: Mipela i save ting olsem. (katimpik, sutim pisin, skulim ol long tokples, toktok, ting) 
Exercise 2: Repeat the following sentences inserting the negative marker no in the correct place.

1. Dispela meri $i$ ( ) save brumim ples.

(pause)

2. 01 dispela man $i($ ) save singsing.

(pause)

3. Mi () save go long lotu.

(pause)

4. Dispela dok i () save kaikai ol kakaruk.

(pause)

5. Olgeta pikinini i () save lap.

(pause)

\section{Exercise 3: Listen to the following sentences and then change them into ones describing the characteristic habit of the person or thing mentioned. To do this listen to the instructor's cue and then complete the sentence with bilong. For example, suppose the given sentence was 01 taim oltaim em i save kaikai bulmakau and the Instructor's cue was Em i man your answer should be Em i man bilong kaikai bulmakau. Ready?}

1. Oltaim oltaimem i save pait.

(Em $i$ man)

Em i man bilong pait.

2. Oltaim oltaim ol dispela pik i save brukim banis.

(01 dispela i pik)

01 dispela i pik bilong brukim banis.

3. Oltaim oltaim mi save stap long nambis.

(Mi man)

Mi man bilong nambis.

4. Oltaim oltaim stuakipa i no save bekim senis.

(Stuakipa i no man)

Stuakipa i no man bilong bekim senis.

5. 0ltaim oltaim dispela meri i save toktok.

(Dispela i meri)

Dispela i meri bilong toktok.

6. 0ltaim oltaim dispela pikinini i save brumim ples.

(Dispela i pikinini)

Dispela i pikinini bilong brumim ples.

7. Oltaim oltaim em i save skulim mipela long tok Inglis.

(Em i meri)

Em i meri bilong skulim mipela long tok Inglis.

8. 0ltaim oltaim ol i save giaman.

(01 i man)

01 i man bilong giaman. 


\section{Evaluation Exercises}

Exercise 1: Make the following sentences habitual ones. Ready?

1. Long nait Wanipe tupela MALOLo i ( ) sindaun toktok wantaim Dogare.

(pause)

2. Long wanem taim san i ( ) godaun?

(pause)

3. Hanwas bilong mi i no () ran kwik.

(pause)

4. Yu ( ) wokim haus olsem wanem?

(pause)

5. Stuakipa i no () senisim dispela.

(pause)

Exercise 2: How would you ask someone the following questions in Pldgin? Ready?

1. What do you(2) normally do on Sunday? (pause) Yutupela $i$ save mekim wanem long Sande? ${ }^{1}$ \{Long Sande yutupela i save mekim wanem?

2. Where do pigs go at night? (pause) 01 pik i save go we long nait?

3. Who normally collects the pay? (pause) Husat i save kisim pe?

4. What time does the passenger truck normally (pause) come?

Long wanem taim pasindia trak i save kam?

5. Where does the kiap usually sleep? (pause)

$$
\text { Kiap i save slip we? }
$$

\section{TEXT}

Listen to the following rather difficult text and then see how much of $1 t$ you can transcribe and/or translate. Here is the text: ${ }^{2}$

Taim bilong kisim ka yumi laik go long Wewak, long moning kirap tasol, kisimka i go, wokabaut long rot, painim pasindia, kisim, makim wanem hap ol i--wanem hap ol i laik go longen yumi i--ol i askim mipela long prais, ${ }^{3}$ bai tokim ol long prais long wanem hap. Em nau. 01 i gat mani, ol i baim, mipela i kisimol. Go, bringim ol long

\footnotetext{
${ }^{1}$ Also: Yutupela i save mekim wanem samting long Sande? or Long Sande yutupela i save mekim wanem samting?

2 This text is spoken by Pakai, a P.M.V. driver, from Tumam village. Pakai is aged about thirtyfive and is fairly acculturated.

3 prais $=p e=$ cost, charge
} 
dispela hap, sampela lain i laik kalap gen, ol go long Wewak na tokim ol long pe $e^{2}$ bilong go long Wewak, na ol i baimka, mipela i bringim ol long Wewak. I kam bek tu, taim mipela i lusim Wewak, mipela i kam bek, ol man long rot ol i laik kam, go daun long rot man bilong kam long Dre'kikir ol i laik kam, O Maprik, mipela i kisim ol, long Wewak, kam bringim ol gen long rot, bringim ol long Yangoru o Maprik, sampela bilong Dre'kikir, mipela bringim ol, sampela i laik kam long ples, ${ }^{3}$ mipela bringim ol i kam long ples. Na kirap gen long moning, mipela i ting wanem man i ripot gen long kisimol, mipela i kisimol gen, i go. Na i no gat man i ripot, yumi kirap tasol yumi tingim long wanem hap bilong painim pasindia, yumi go tasol. Go painim ol pasindia, kisim ol i go, bringim ol long wanem hap, kisim mani long ol, i kam bek gen. Olgeta taim olsem.

Em tasol.

[Playing time: 1.5 minutes]

ENGLISH TRANSLATION :

When it's time to get the truck (note ka) for us to go to wewak (we) get up in the morning, get the truck and go driving along the road in search of passengers. (We) pick them up and note (= makim) where they want to go and we--they ask us about the fare and we outline these for various distances (lit. tell them about the fare for which place). Then those that have money pay their fare and we take them. (We) take them to their destination. Some groups want to board again to go to Wewak and we tell them the fare to Wewak and they pay it and we take them. (We) come back too. When we leave Wewak to come back those who live along the road or who come from Drekikir or Maprik and want to come back home (2it. get down at their place) we pick them up at Wewak and bring them (back) again along the road--bring them to yangoru or Maprik. We bring some for Drekikir and some for Tumam. In the morning (we) get up again and consider the reports that have come in again about picking up passengers ( $2 i t$. we think about which man reported about getting them) and we (go and) take them. If no one reports we get up and decide on where to go

\footnotetext{
$I_{\text {kalap }}=$ get into a car, board. Also means to jump, spring, leap, e.g., kalap i go daun to jump down.

2 pe. See footnote 3 on previous page.

3 long ples = Tumam village

${ }^{4}$ ripot $=$ report
} 
looking for passengers and go. We (go and) look for passengers and take them to wherever (they want to go), get their money and come back again. And so it goes on (lit. every time is like that). That's all.

Now to end this unit here is another Pldgin song which is sung this time to the accompaniment of a Ukulele. Here are the words to the song:

$$
\begin{aligned}
& \text { Yu go tokim Toni } \\
& \text { Siket }{ }^{1} \text { i bruk pinis } \\
& \text { Toni e, Toni e, Toni e }
\end{aligned}
$$

\section{SUPPLEMENTARY VOCABULARY}

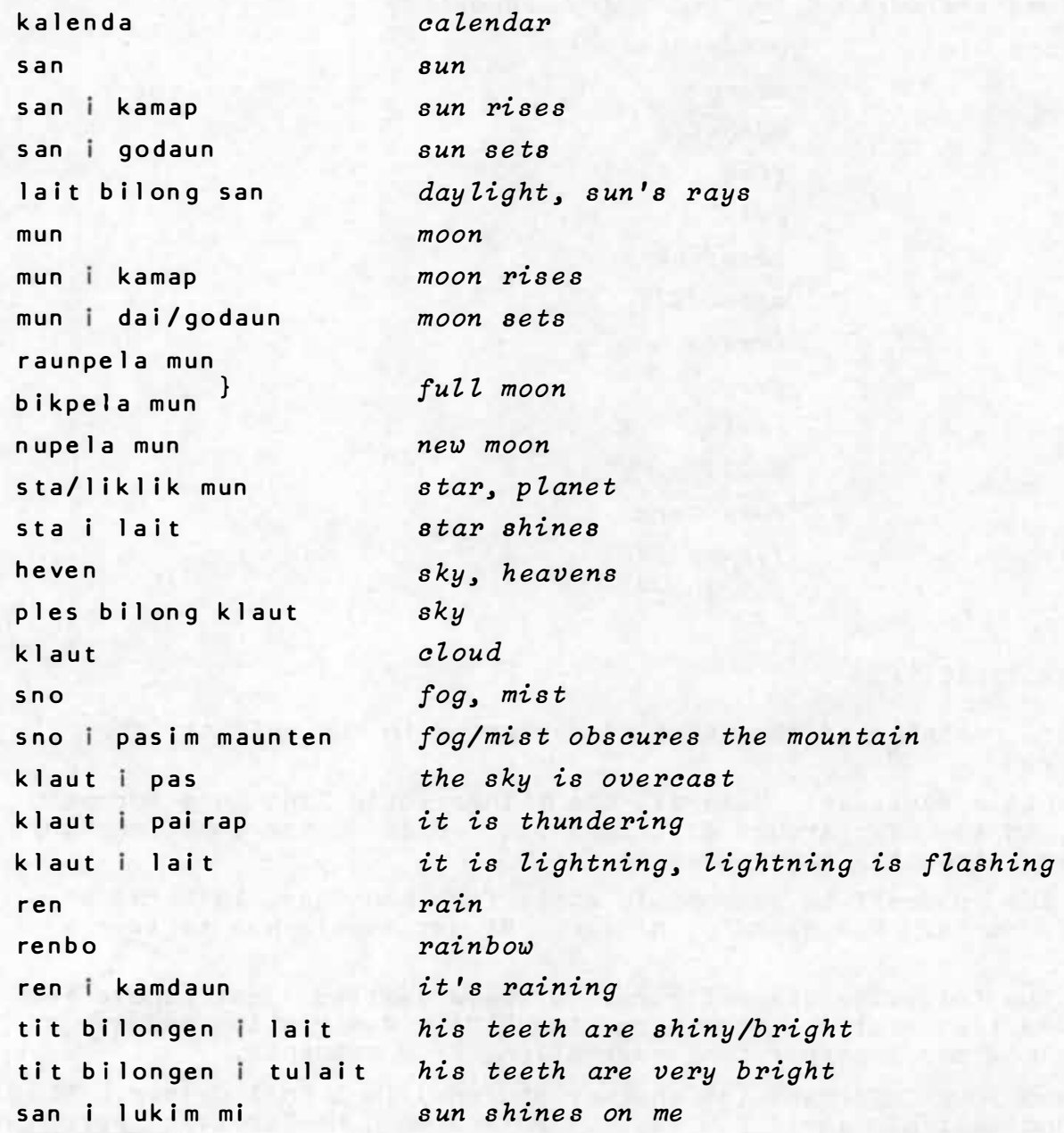

$I_{\text {siket }}=$ skirt 


\begin{tabular}{|c|c|}
\hline lukim meri & the girl is menstruating \\
\hline belo bilong klok & clock's alarm \\
\hline paitim belo & ring the bell \\
\hline $\begin{array}{l}\text { tudak } \\
\text { ren }\end{array}$ & $\begin{array}{l}\text { darkness } \\
\text { rain }\} \text { caught me on the way }\end{array}$ \\
\hline ren $\mathrm{i}$ wasim mi & I got rained on \\
\hline taim bilong ren & the rainy season \\
\hline taim bilong san & dry season \\
\hline taim bilong kaikai & Zunch time \\
\hline $\begin{array}{l}\text { taimbilong kirap long } \\
\text { slip }\end{array}$ & getting-up time \\
\hline taim bilong haiwara & high tide, rainy season \\
\hline taim bilong draiwara & Low tide, dry season \\
\hline taim bilong win & windy time \\
\hline tais & swamp \\
\hline natnat & mosquito \\
\hline pis & fish \\
\hline maleo & $e e z$ \\
\hline kindam & crayfish \\
\hline pukpuk & crocodile \\
\hline binatang & insect \\
\hline rokrok & frog \\
\hline s nek & snake \\
\hline sikau & wazzaby \\
\hline muruk & cassowary \\
\hline blakbokis & flying fox \\
\hline mumut & bandicoot \\
\hline
\end{tabular}

\section{CLASSROOM EXERCISES}

Besides revision of the material presented in the unit try the following:

1. Vocabulary Revision: Name all the things you'd find in a European kitchen; in the sky; around a village etc. Base on the supplementary and other vocabulary introduced so far.

2. Describe yourself to someone in about five sentences in terms of your body parts. For example, Mi man. Mi gat tupela han na tupela lek...

3. Draw the following crazy figure. Dispela samting $i$ gat tupela het na wanpela lek tasol... Give a running Pidgin description made-up as you go along and incorporating suggestions from students.

4. Pretend your informant (or another student) is a taxi driver. Ring him up and tell him where you want to go and when he "arrives" carry on a conversation with him on the way to your destination. Conversation should include discussion of fare. 
5. Repeat the Cumulative Text game given in Unit 2 but ask for it to be done in the future using bai.

6. Begin a reading programme based on some of the material mentioned in Section 3 of the Reading List given at the end of this book.

7. Give (or write down) sentences showing that you know how to ask the following common types of questions: Where?; How much?; Why?;

Who?; When?; Whose?; How?; Are you...?; How many?; Is he... or not?. 


\section{UNIT 5}

\section{CONVERSATION}

Long Painim Wok

Long moningtaim Dogare i kirap long slip na i baim bas i go long taun bilong painim wok. Em i

raun i stap na i kamap long opis bilong wanpela kampani masta. ${ }^{1}$

Masta: Yes, wanem samting?

Dogare: Masta mi laik i kisim wok.

Masta: Yubin wok mani bipo? ${ }^{2}$

Dogare: Yesa, bipo mi bin wok mani long masta Sak long Goroka. 3

Masta: Tru a? Yu save wokim baret bilong putim s imen?

Dogare: Yesa, mi save.

Masta: Tasol yu inap wokim em long san? 4

Dogare: Mi inap wokim em olsem.

Masta: Orait yu kam bek gen long Mande long seven klok bilong kirapim dispela wok. Save?

Dogare: Yesa, mi harim.

Olsem na Dogare i lusim opis i go na $i$ wokabaut long taun.
In the morning Dogare woke up and caught the bus to town to look for work. He walked about and (eventualzy) arrived at the office of the manager of a firm.

Yes, what's the trouble?

I want to get work, sir.

Have you worked for wages before?

Yes sir, some time ago I worked

for wages for Mr. Jack in

Goroka.

Is that so huh? Do you know how to make a trench for cement?

yes I do.

But can you do it in the sun?

I can do it under those conditions. ok come back again on Monday at seven to begin. Understand?

Yes sir, I understand.

And so Dogare left the office and strolled about town.

[Musik ${ }^{5}$ ]

\footnotetext{
${ }^{1}$ Note difference between wanpela kampani masta a European businessman or employer and kampani bilong wanpela masta a certain European's business or company.
} 
2 Depending on the location and the work undertaken one employs labour on wage, piece, contract, or board-and-keep conditions.

3 Europeans are more commonly named and remembered by their christian names rather than surnames in New Guinea.

${ }^{4}$ See footnote to section 5.2 .

5 The traditional music heard throughout this unit comes from the Madang area. It is taken from Sheridan (1958: side 1, track 2, item a) who describes it as follows:

An important ritual of the buraung ceremony of initiation.

The song is introduced by the dige. This is a tube of bamboo at least twelve feet long. The music of the dige is produced by the performer partly singing, and partly trumpeting into the tube. A reed made from a leaf held in the mouth of a player seated just behind the dige group sounds out a soprano version of the main theme. This tiny instrument is the mumo.

USEFUL EXPRESSIONS

Wanem samting?

Nogat .

I no gat samting.

Yu orait a?

Yes, mi orait.

$\mathrm{Yu} g \mathrm{gt}$ tok?

Nogat, mi no gat tok.
What's the matter?/What's up? Nothing.

Nothing's the matter.

Are you ok?/How are you?

Yes, I'm ok./Fine!

Have you got something to say?

No, I've got nothing to say.

\section{VOCABULARY EXPANSION EXERCISES}

\section{Exercise 1: Simple Substitution}

Frame: Masta, mi laik i kisim wok.

$$
\begin{aligned}
& \text { maritim dispela meri (marry this woman) } \\
& \text { ranawe long ples (run off home) } \\
& \text { raitim nem bilong mi (write my name) } \\
& \text { katim gras bilong het (give you a haircut) } \\
& \text { bilong yu } \\
& \text { bihainim pasin bilong (imitate you } \\
& \text { yupe la } \\
& \text { Europeans) } \\
& \text { kaunim haumas mani i (count how much } \\
& \text { stap money there is) } \\
& \text { bungim ol samting (put my things to- } \\
& \text { bilong mi gether in a heap) }
\end{aligned}
$$


Exercise 2: Simple Substitution

Frame: Yu bin wok mani bipo?

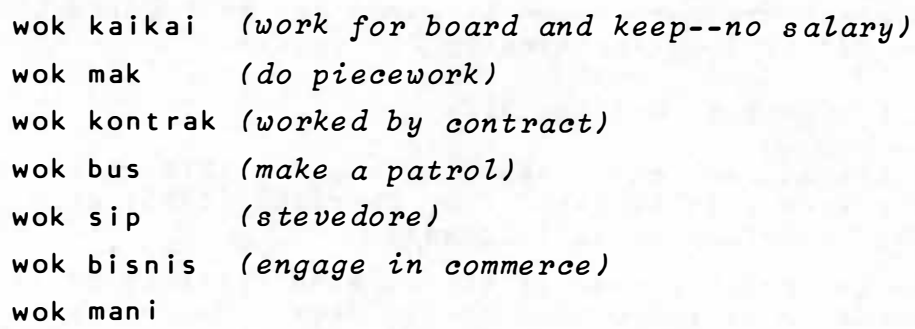

Exercise 3: Simple Substitution

Frame: Yu save wokim baret bilong putim simen?

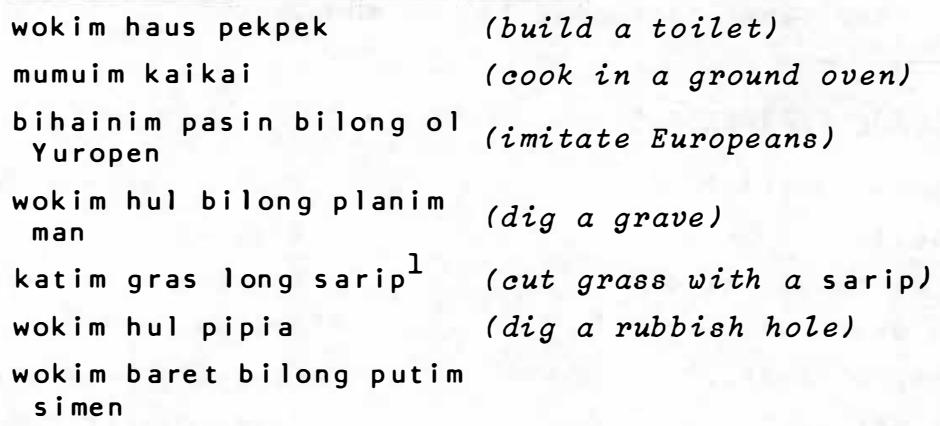

Exercise 4: Simple Substitution

Frame: Tasol yu inap wokim em long san.

$\begin{array}{ll}\text { helpim mi } & \text { (help me) } \\ \text { planim kaukau } & \text { (plant sweetpotato) } \\ \text { wasimka } & \text { (wash the car) } \\ \text { brumimples } & \text { (sweep the village) } \\ \text { sanapimpos } & \text { (stand up the post) } \\ \text { pilaikikbal } & \text { (play soccer) } \\ \text { kisim diwai i kam } & \text { (bring poles) } \\ \text { soimmi rot } & \text { (show me the way) } \\ \text { wokimem } & \end{array}$

${ }^{1}$ A sarip is a long thin piece of iron about three feet long by one inch wide used for cutting grass in New Guinea. 


\section{Exercise 5: Simple Substitution}

Frame: Orait, yu kambek gen

long Mande.

$\begin{array}{ll}\text { wanpela taim moal } & \text { (once more) } \\ \text { tupela taim moa } & \text { (twice more) } \\ \text { tu-tri taim } & \text { (a few times) } \\ \text { planti taim } & \text { (often) } \\ \text { haumas taim } & \text { (how often?) } \\ \text { gen }{ }^{2} & \end{array}$

Exercise 6: Progressive Substitution

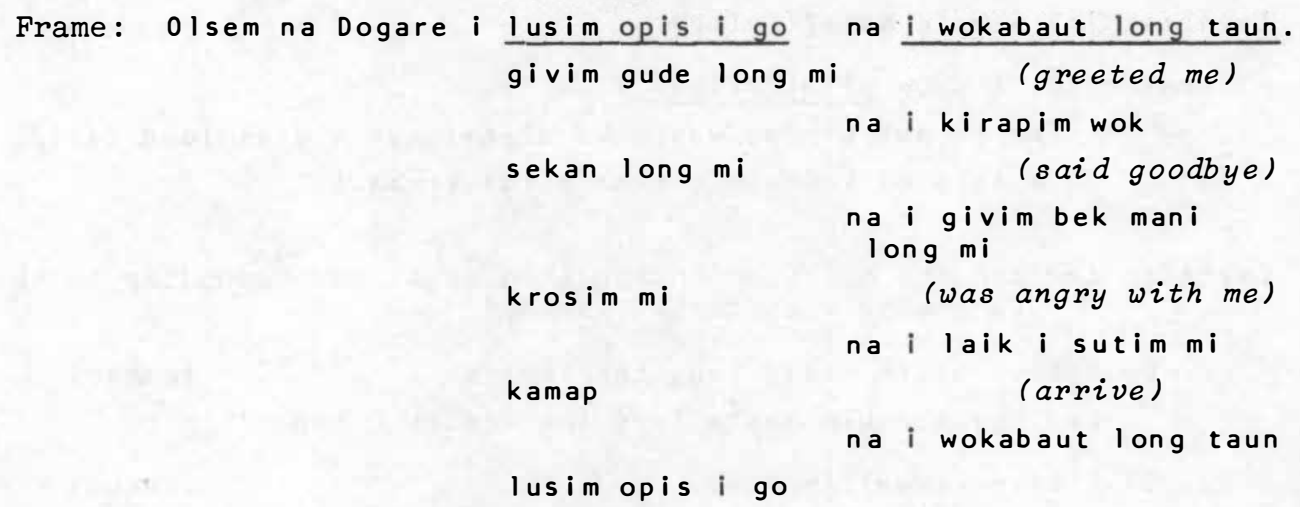

\subsection{SAVE + VERB: COMPETENCE (to know how to do something)}

Competence in performing an action is expressed in Pidgin by placing save before the verb just as for habitual actions discussed in Section 4.4 above, e.g.:

Yu save wokim baret bilong Do you know how to dog a trench putim simen? for cement?

Mi save wasim ka. I know how to wash a car.

In fact the two constructions are closely related in that one gains one's competence to perform an action from having performed it regularly or habitually. In some sentences both senses are one and the same, e.g. :

Yu save wokim haus. Do you regularly build houses? 'Do you know how to build houses?

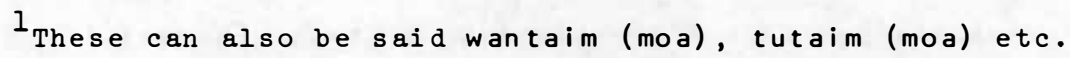

2 Two other useful time expressions which students should know but which do not fit this frame are oltaim always and wanpela wanpela taim occasionally, now and then, at odd times. 01 taim usually comes at the beginning of sentences and may be doubled for intensity.

Examples: Oltaimemi sik. He's always sick. oltaim oltaim em i sik. He's continually/always sick.
} 
Mipela i kaikai bulmakau

wanpela wanpela taim tasol.

We (excl.) eat beef only now and then.

In others only one is emphasised, e.g.:

San i save godaun. The sun (habitually) goes down.

Notice, however, that Pidgin makes a distinction between this and special knowledge (save pasin bilong; gat save bilong) which will be discussed in more detail later.

\section{Practice Drills}

\section{Exercise 1: Simple Substitution}

Frame: 01 i save pilai kikbal.

(wokim hul pipia; wasim ka olsem; katim gras long sarip; bungim ol kokonas olsem; pilai kikbal)

Exercise 2: Ask the question ending in o nogat corresponding to the following statements. Ready?

1. Em i save askim masta long tok Inglis.

(pause)

Em i save askim masta long tok Inglis o nogat?

2. 01 i save kapsaitim kanu.

01 i save kapsaitim kanu o nogat?

(pause)

3. Olgeta manmeri bilong Papua Niu Gini i save toktok (pause) long tok Pisin.

Olgeta manmeri bilong Papua Niu Gini i save toktok long tok Pisin o nogat?

4. Yu save bihainim pasin bilong ol Yuropen?

(pause)

Yu save bihainim pasin bilong ol Yuropen

o nogat?

5. Emtupela i save wok bus.

(pause)

Emtupela i save wok bus o nogat?

\section{Evaluation Exercises}

Exercise 1: Give the English meanings of the following sentences. In most cases there will be two, according to the interpretation of save and the context.

1. Kiap i save salim pas i go long opis long biktaun. (pause)

The government officer habitually sends/knows how to send letters to the office in the main town.

2. 01 manmeri bilong 0strelya i save kaikai kakaruk. (pause) Australians habitually eat/know how to eat fowl. 
3. Pasindia trak i save kam bek long hap pas sikis (pause) samting.

The passenger truck usually comes back about half past six.

4. Mun i no save kamap long faiv klok stret.

(pause)

The moon doesn't usually rise at exactly five o'clock.

5. Mi no save go long lotu.

(pause)

I don't usually/don't know how to go to church.

Exercise 2: How would you say the following things in Pidgin:

1. Do you know how to write a letter in Pidgin or not? (pause)

$\mathrm{Yu}$ save raitim pas long tok Pisin o nogat?

2. My father knows how to shoot fish.

(pause)

Papa bilong $m i$ save sutim pis.

3. This old man knows how to dig a rubbish hole.

(pause)

Dispela lapun man i save wokim hul pipia.

4. All boys know how to play soccer.

(pause)

olgeta manki i save pilai kikbal.

5. His male servant knows how to cook corned beef. (pause)

Hausboi bilongen i save kukim solmit.

6. This European woman knows how to harvest sweetpotato huh?

(pause)

Dispela misis i save kamautim kaukau a?

\subsection{INAP V: ABILITY (Physically Capable)}

Ability to carry out an action physically is expressed in Pidgin by placing inap (or often just $n a p$ ) before the verb, 1 e.g.:

Mi inap sanapim dispela pos. I can (am physically able to) stand up this post.

Em i no inap kamautim kaukau. She cannot (is not physically able to) harvest the sweetpotato.

Bai em i no inap kamautim kaukau.

She'll not be able to harvest the sweetpotato.

Yu inap i go long taun?

Are you able to go to town?

Yu inap i kam wantaim em?

Are you able to come with him?

Note the position of no and bai with respect to inap in these sentences, and that $i$ appears before go and kam after inap.

${ }^{I}$ In some areas inap $i$ is used, e.g., Mi inap i sanapim dispela pos, and $E m$ i inap i kamautim kaukau. Note that this is different from the occurrence of $i$ before go and kam mentioned below. 
Practice Drills

Exercise 1: Simple Substitution

Frame: Mitupela i inap katim gras bilong het bilong yuu.

(wok kontrak, mumuim kaikai, $i$ go long taun bilong

kisimpe; wok bus, katim gras bilong het bilong yu)

Exercise 2: Simple Substitution

Frame: Bai ol i no inap rausim gras nogut long gaden.

(lukautim ol pikinini; kilim indai pik; bringim kago

i kam; wokabaut long bung; rausim gras nogut long gaden)

Exercise 3: G1ve the abllity form of the following sentences by inserting inap in the correct place. Be wary of go and $\mathrm{kam}$.

1. Meri bilongen i ( ) redim kaikai bilong tupela. (pause)

2. 01 i ( i) kam bek long de namba tu bilong mun

Epril.

(pause)

3. Emtripela i () kisim kaukau i go long haus sik. (pause)

4. Kandere bilong mi i () raitim pas na salimem

i kam long mi.

(pause)

5. Dispela tupela pikinini meri $i$ ( ) klinim gaden. (pause)

6. Mi no ( i) go long nambis. (pause)

Exercise 4: Make the following sentences negative by inserting no in the correct place:

1. Meri bilongen $i$ ( ) inap redim kaikai bilong tupela.

(pause)

2. 01 i ( ) inap i kam bek long de namba tu bilong mun Epril.

(pause)

3. Emtripela i ( ) inap kisimkaukau i go long haus sik.

(pause)

4. Kandere bilong mi i () inap raitim pas na salim em i kam long mi.

(pause)

5. Dispela tupela pikinini meri $i$ () inap klinim gaden.

(pause) 


\section{Evaluation Exercise}

Answer the following questions using the Pldgin cues provided:

1. Yupela i inap subim ka i go?

(yesa) (pause)

Yesa, mipela i inap subim ka i go.

2. Yupela i inap subim ka i go?

(nogat) (pause)

Nogat, mipela i no inap subim ka i go.

3. Dispela lapun meri i inap sanapim dispela pos?

\section{(nogat) (pause)}

Nogat, dispela lapun meri i no inap sanapim dispela pos.

4. Em i inap wokim wanem?

(haus kuk) (pause)

Em i inap wokim haus kuk.

5. Bai yu no inap i go we?

Bai mi no inap i go long bikbus.

(bikbus) (pause)

\subsection{BIN + VERB: PAST TENSE}

Verbs preceded by bin denote actions performed in the past, e.g.:

Wanpela man i bin skulim mi A man was/has been teaching me

long tok Pisin. Pidgin.

Note, however, that bin is not used in P1dgin as frequently as one might expect on the basis of one's knowledge of English where tense 1s always indicated in the form of the verb. Th1s is because bin seems to be a recent development in some areasl and because (as already noted in Unit 1 Section 1.2) verbs in P1dgin rely more on context (especially adverbs/phrases of time) for their interpretation than do verbs in English. Students should therefore be wary of overuse of bin. As a general rule use bin to indicate past tense only when 1t is not likely to be clear from context that past tense is being Indicated, or as roughly equivalent to have, has in English. The following exercises will give you practice in manipulating bin, but are not meant to be taken as a measure of 1 ts frequency of use.

\section{Practice Drills}

\section{Exercise 1: Simple Substitution}

Frame: Husat i bin mumuim kaukau hia?

(bungim olgeta samting, planim man, katim diwai, katim gras, giaman, wokim hul, mumuim kaukau)

\footnotetext{
$I_{M r}$. P. Mülhaüsler informs me that in some of the more remote areas of the Sepik it is not known by older people. It is said to have originated in New Britain and is made popular by radio announcers.

2 For further discussion of the use of bin see Mihalic (1971:29) and Wurm $(1970: 47)$.
} 


\section{Exercise 2: Simple Substitution}

Frame: Nogat, mitupela i no bin paitimem pastaim.

(krosim dispela, ranawe, kamap, sanapim pos, patim em)

Exercise 3: Make the following sentences negative by inserting no in the correct place:

1. 01 kanaka $i($ ) bin lukim nambis.

(pause)

2. Smolpapa bilongen $i$ ( ) bin dring kopi.

3. Yu ( ) bin soim rot long olgeta.

(pause)

4. Husat $i$ ( ) bin haitim kago?

5. Yumitripela i () bin baim balus.

(pause)

Exercise 4: Change the following sentences from past tense marked by bin to future tense marked by bai. In each case begin the sentence with bai. For example, if the instructor were to say ol $i$ bin $k a m$ your answer should be bai ol $i$ kam. Ready?

1. Mi bin soim em wanpela ples kanaka.

(pause)

Bai mi soim em wanpela ples kanaka.

2. Kiap i bin givim gude long hausboi bilong mi.

(pause)

Bai kiap i givim gude long hausboi bilong mi.

3. Em tripela i bin helpim dispela manki.

(pause)

Bai em tripela i helpim dispela manki.

4. Mipela i no bin bihainim pasin bilong ol Yuropen. (pause)

Bai mipela i no bihainim pasin bilong ol Yuropen.

5. Yupela i bin wok bus a?

(pause)

Bai yupela $i$ wok bus a?

\section{Evaluation Exercise}

What do the following sentences mean In English:

1. Dispela haptrak i bin kilim i dai mamabilong mi. (pause) This utility killed/has killed my mother.

2. Yu bin stap we?

(pause)

Whe re have you been staying?

3. Long wanem taim em i bin sindaun toktok?

(pause)

When was he sitting down talking?

4. Mipela i bin planimmeri long seven klok samting. (pause)

We (excl.) were burying the woman at about $?$ o'clock.

5. Dok i bin ranawe long bikbus.

(pause)

The dog ran/has run away in the jungle. 


\subsection{VERB + GEN : REPEATED ACTIONS}

Verbs followed by gen indicate repeated actions, e.g.:

01 i sindaun gen. They are sitting down again.

But although gen always follows the verb 1ts position relative to 1 t in longer sentences is falrly flexible except if there is an object involved. In that case gen cannot occur between the verb and the object without special intonation and pausing (which tend to emphasise gen) and then only for non-pronoun objects with certain verbs. The following sentences indicate the kinds of allowable varlation. Unacceptable sentences are starred and less acceptable ones questionmarked.

Examples:

1. 01 i sindaun gen long graun. They are sitting down again on 01 i sindaun long graun gen. the ground.

2. 01 i lukim mi gen. *0l i lukim gen mi. They saw me again.

3. Em i paitim masta gen long $k$ anda.

Em i paitim masta long kanda gen. walking-stick again.

*Em i paitim gen masta long kanda.

4. Bai mi givim yu wanpela pik gen.

Bai mi givim wanpela pik long yu gen.

Bai mi givim wanpela pik gen long yu.

?Bai mi givim yu gen, I'2 give you a pig again. wanpela pik.

?Bai mi givim gen, wanpela pik long yu.

* Bai mi givim gen yu wanpela pik.

Practice Drills

\section{Exercise 1: Simple Substitution}

Frame: 01 i sindaun gen long graun.

(stap, sanap, pekpek, singsing, slip, sindaun)

\section{Exercise 2: Simple Substitution}

Frame: 01 i lukimmi gen.

(stilimkiau, baim bas, sutim pik, pilaikikbal, planim taro, lukim mi) 
Exercise 3: Simple Substitution

Frame: Em i paitim masta gen long kanda.

(katim diwai gen long akis, sanapim pos gen long hul, kisim wok gen long Mosbi, paitim masta gen long kanda)

Exercise 4: Simple Substitution

Frame: Mi hat gen.

(kol, pulap, kus, sotwin, hat)

Exercise 5: Repeat the following sentences substituting the items given as cues for gen.

1. 01 pik bilong mi $i$ ranawe gen long bikbus. (wantaim moa)

01 pik bilong mi i ranawe wantaim moa long bikbus.

2. Yumi i toktok gen long tok Pisin. (wanpela wanpela taim)

Yumi i toktok wanpela wanpela taim long tok Pisin.

3. 01 pisin i sindaun gen long dispela diwai. (planti taim) 01 pisin $i$ sindaun planti taim long dispela diwai.

4. Sampela $i$ no inap $i$ go antap gen long stesin. (tupela taim) Sampela $i$ no inap, go antap tupela taim long stesin.

5. 01 meri i subimka $i$ go gen. (tu-tri taim) 01 meri i subim ka i go tu-tri taim.

\section{Exercise 6: Progressive Substitution}

Frame: Papa bilongmi bai i givim yu wanpela pik gen. susa bilongen

brata bilong emtupela nupela kiau

brata bilong emtupela

kandere bilong dispela

liklik kaikai

kandere bilong dispela

smolpapa bilong mipela

gutpela wilwil

papa bilong mi

bikpela kakaruk

wanpela pik

Exercise 7: Repeat the following frame inserting gen into the phrase given as cue. Use the answer then as the frame for the next cue insertion, and so on. Ready?

Frame: Em i wetim bas gen. 
Em i kam bek gen long Mosbi.

(ranawe long ples)

Em i ranawe gen long

ples.

(lainim tokples long teprikoda)

Em i lainim tokples gen long teprikoda.

(putim kiau long haus kakaruk)

Em i putim kiau gen

long haus kakaruk.

(wetim bas long bikrot)

Em i wetim bas gen long bikrot.

Evaluation Exercise

Say what the following sentences mean in English. Treat each as necessary as being in the past tense.

1. 0 l hanwas $i$ dai gen long ten minit bipo long ten klok stret.

(pause)

The watches stopped again at exactly ten to ten.

2. Yumi i wok gen.

(pause)

We (incl.) worked again.

3. Kaman, yumi wok gen! ${ }^{1}$

(pause)

Come on, let us (incl.) work again!

4. Pisin i sindaun gen long het bilongen.

(pause)

The bird sat on his head again.

5. Stuakipa bai i givim ol sampela loliwara gen.

(pause)

The storekeeper will give them some softdrink again.

\section{TEXT}

Here is a story by Muhan of Tumam village, near Dreikkikir, East Sepik District about going to work on a plantation. Listen to it and then try writing it down and translating it. Here is the story:

Orait, nem bilong mi Muhan. Mi bilong ples hia Tumam. Mi laik stori long taim mipela i go long plantesin. ${ }^{2}$ Bipo mipela stap long ples, mipela i no gat laplap o bilas o gutpeladres, samting olsem, mani, wanem samting. Na bihain mipela i stap na harim tok long

\footnotetext{
${ }^{1}$ Check Conversation 3 footnote 5 , and Unit 3 , Vocabulary Expansion Exercise 6 again!

${ }^{2}$ Note the pronunciation of plantesin by this speaker.
} 
kompani masta $i \mathrm{kam}^{\text {long }^{l}} \mathrm{kisim}$ boi long wok long plantesin. Em nau mipela kirap, kisim nem long ol masta ${ }^{2}$ go kamap long Maprik o Wewak wanem hap olsem long sabdistrik, go daun, mipela go kamap nau, mipela kontrak, putim nem bilong mipela, o ples, o kaunsil, o distrik. Nau mipela i putim nem long kontrak nau, mipela i go long plantesin. Mipela wok inap olsem tu yia pinis, mipela pinisim taim ${ }^{3}$ bilong mipela, mipela i kam bek, ol masta i pinisim taim ${ }^{3}$ bilong mipela, mipela i kam nau, kisimpe long gavman, 4 pe bilong kontrak, (?) long gavman, long opis, long wanem hap mipela $i$ wok longen. Mipela $i$ kisim pe nau, mipela i pinis na i kam. Kam mipela baim sampela bilas, o ol gutpela dres o kaikai wanem samting, mipela baim na mipela tingting long sampela famili long ples o papamama o sampela brata, mipela mas baim bilas, ol sottrausis, 501 laplap wanem samt lng mipela mas baim inap long ol susabrata long ples mipela kisim i kam, mipela i dilim wanpela wanpela ${ }^{6}$ long ol, o wan siling, mani samting, mipela laik givimol, helpim ol liklik. Mipela kam i stap, sampela man lukim olsem i tok, "Mi tu mi mas wok mani." Orait, em i kirap, painimbilong em, painim wok mani bilong em, go nau, go kontrak, i go long plantesin. Wok long plantesin i wankain olsem. I go go inap

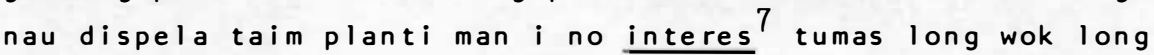

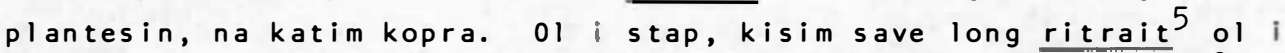
laikim gutpela wok, long stap long taun. 01 wanpela wanpela man 8 ol i save go long plantesin inap nau. Tasol long bipo tru i no gat gutpela wok long taun o wok insait long save. Nogat. Mipela wok olsem long plantesin tasol. Mipela katim kopra. Inap nau, em pinis. Na sampela hap hap lain ${ }^{9}$ tasol ol i wok long plantesin. Tasol long taun, yes, i gat planti moa man ol i wok insait long taun. olsem gutpela kaikai, o gutpela stesin i klin, olsem nau em tok, liklik toksave bilong mi long stori bilong mi long wok long plantesin, taim mi wok longen. Em tasol.

[Playing time: 2.5 minutes]

\footnotetext{
${ }^{1}$ Note use of long for bilong in order to. This is quite common in many areas of Papua New Guinea.

${ }^{2}$ Because of the pause after masta it is not clear if $i$ go refers to masta or to mipela. I shall interpret it as though masta is the subject.

${ }^{3}$ Note here pinisim taim to finish one's contract time has both mipela and masta as subject.

4 In this indentured labour system a certain proportion of a labourer's wages was paid to and held in trust by the government and given to the labourer at the completion of his contract.
} 
${ }^{5}$ Sottrausis clothes ( $2 i t$. shirt and trousers) is said as one word. Cf. manmeri, papamama, bratasusa and ritrait which comes later. 6 wanpela wanpela = one each

7 interes $=$ interested

8 ol wanpela wanpela man = each person, but normally one wouldn't have ol in front as this speaker does.

9 hap hap lain. Not sure whether speaker means this and that group or half of some groups. I think the former.

\section{ENGLISH TRANSLATION :}

Wel2, my name is Muhan. I come from this vilzage, Tumam. I'm going to tell about when we went to (work on) plantations. Before, we were (just) staying in the village. We did not have loincloths or fine clothes or good skirts or things like money or whatever. Then we heard about a recruiter coming to get labourers to work on plantations. So (lit. that was it!) we got going ( $i$ it. got up) and got the names of the recruiters coming to Maprik or Wewak or whatever place like that in the subdistrict and we went and saw them and signed on--put (down) our names or of our village, council or district. Then (when) we had signed on we went to the plantation. We worked for two years and at the completion of our contract we came back--the plantation manager completed our contract and we came back, collected our due wages from the government--(?) from the government, at the (government) office wherever we were working. Having collected our pay we were finished (with our contract) and came (home). On the way we bought some finery or nice dresses or food or whatever. We bought them for our relatives back home (lit. we thought of some relatives in the villagel or parents or some brothers. We had to buy finery--clothes, loincloths etc.-we had to buy enough for our brothers and sisters in the vilzage. We bought them and shared them out, one each--or (gave them) one shilling or money and things. We wanted to give them (these things) to help them a little. When we were coming some (others from the vilzage) would see us (with our goods--lit. like that) and say, "I too must work for wages." So they'd get up and (go and) look for it--for work that paid wages for them. They'd go--go and work contract on a plantation. Work on a plantation is all the same, (just) like I've told you (lit. like that). This business (lit. it) went on until the present time. Many men are not (now) interested very much in working on plantations and cutting copra. They stay (in the village) and learn to read and write. They want good work, in a town. Each person used to go to a plantation till now. But before, long ago, 
there was no good work (to be had) in towns or to do with knowing things. No. We only used to work on plantations. We used to cut copra, but all that's over now. Only this and that group work on plantations (any more). But in towns, yes, there are plenty more men working. "There (you'll find) good food and clean stations," that's what they say. That's all there is to my little explanation of what it was like to work on plantations.

Now to end this unit here is a sound common to the Highlands areas of New Guinea. It is a yodel call whlch is used to send messages across valleys. Such a call is a comblnation of spoken and singing speech and may carry up to a mile or more. This example comes from Sherldan (1958: s1de 2, track 1, 1tem a).

\section{SUPPLEMENTARY VOCABULARY}

More Body Pants

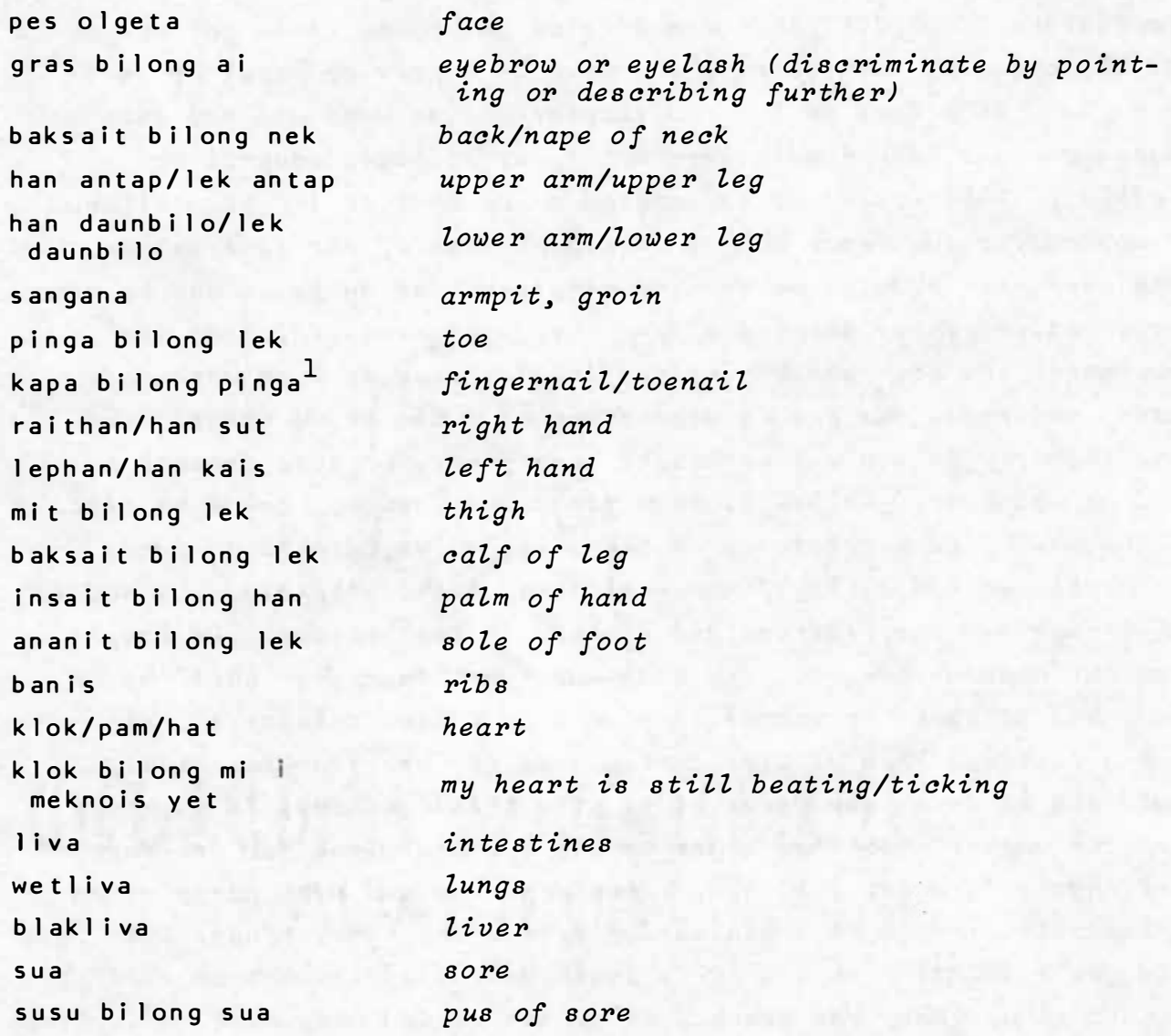

${ }^{1}$ Note: Fingers are normally identified by pointing or describing, e.g., dispela pinga or longpela pinga. 


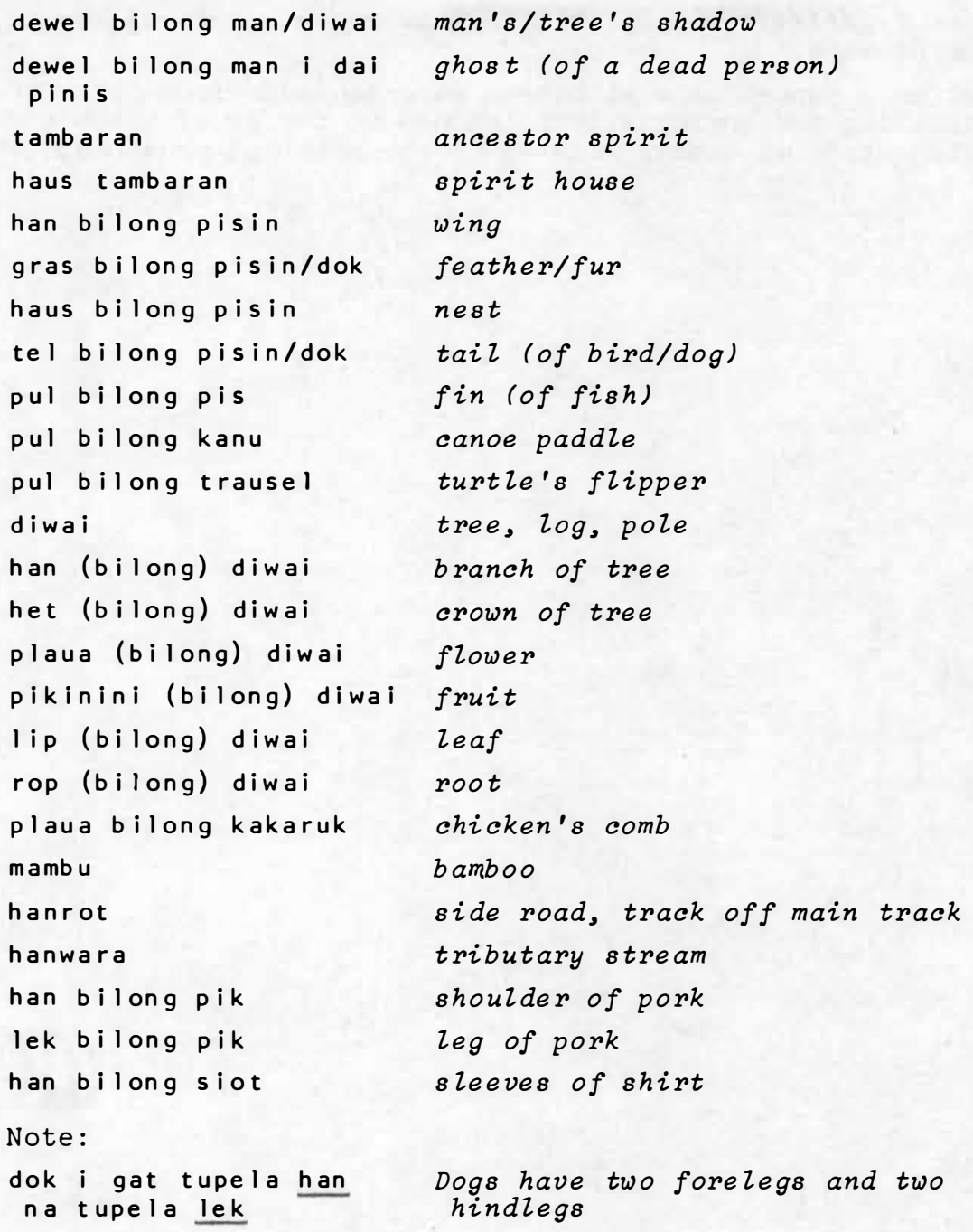

\section{CLASSROOM EXERCISES}

Besides revision and practise of materials presented in the units studied so far try the following:

1. Language Game: Delivering Messages. Get one student to give a message to another outside the classroom and send him off to the class to deliver the message and/or explain what he wants. E.g., send to shop, to teacher, to kompani masta, to wantok etc. At completion another student can describe what happened in Pidgin or whole class write a short description.

2. Language Game: What am I? Class members compose three sentences about some object and present to rest of class to guess what that object is. All must be in Pidgin. Allow class to question if necessary. (Restrict to few minutes only on each occasion.)

3. Language Game. Mime an action and class has to ask what the performer is doing and then say what he is doing. (Restrict to few minutes only on each occasion.) 
4. Comprehensive Exercise. Supply written answers to questions about a short text or picture.

5. Students put on a puppet show with hand puppets (made from old socks) recapitulating the conversations learned so far/or of a short drama of the students' own design related to the material presented so far. 


\section{UNIT 6}

\section{CONVERSATION}

\section{Long Pati}

Long Fraide Dogare i putim ${ }^{1}$

klinpela siot na trausis brata

bilongen i givimem pinis na

em $i$ go long pati. ${ }^{2}$ Taim em $i$

kamap long pati em i lukim

sampela wantok bilongen.

Wantok: Yes brata, yu kam a?

Yu laik i mekim wanem

samting long pati hia

na yu kam?

Dogare: Nogat, mi kam nating

tasol. Brata bilong $\mathrm{mi}$

i tokim mi na mi kam.

Em tasol.

Wantok: Oloboi, yu man bilong

giaman hia. 3

Dogare: 01 sem wanem? 4

Wantok: Yu putim dispela klinpela siot na trausis, na yu smat moa i stap. Bilong wanem?

Dogare: Nogat, mi bilas nating.

Wantok: Nogat hia. ${ }^{3}$ Mipela

olgeta i save. Yu laik

i winim wanpela naispela

meri long pati hia. 3

Tru, o nogat?

Dogare: Nogat. Mi no gat mani.

Em i namba wan 5 taim

tru mi kam long pati

long Mosbi.

[footnotes overleaf]
On Friday Dogare put on a clean shirt and pair of trousers which his brother had given him and went to a party. When he arrived at the party he met some friends.

Hello there mate. What are you doing at this party?

No reason. My brother told

me about it and I came. That's a zr.

Boy what a liar.

How come?

You put on this clean shirt and pair of trousers and you look great. Why?

No I dressed up for no reason. Come off it. We know. You want to get yourse lf $_{\text {an }}$ attractive girl here at the party. True or false?

False. I haven't got any money. This is the first time ever that I've been to a party in Moresby. 
Wantok: I orait. Maski. Yu kam pati wantaim mipela olgeta. klostu ol i paitim gita.

Dogare: 0 sori, bipo long tenpela yia samting i no stap

ol sem.

Olsem na Dogare $i$ amamas tru long olgeta samting $i$ stap insait long pat i. ok. Forget it. Come and party with us. They're about to begin playing the guitars.

Alas, ten years ago it wasn't like this.

And so Dogare enjoyed everything at the party.

\section{$\left[\right.$ Musik ${ }^{7}$ ]}

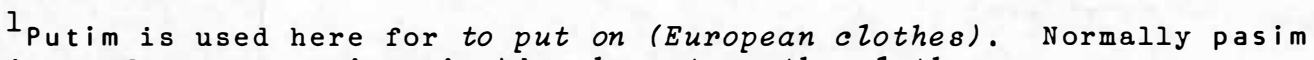
is used, e.g., em i pasim klos he put on the clothes.

${ }^{2}$ pinis indicates completed action. See section 9.2 .

3 Note the frequent use of hia throughout this text. This is characteristic of some speakers who punctuate their speech with it very much like some speakers of Australian English punctuate their speech with like. In these circumstances hia loses much of its demonstrative force and is rather meaningless. Normally it means here when it occurs after verbs (e.g., yu putim kiau daun hia put the egg here!) and this particular (one) here after nouns, e.g., long pati hia at this particular party (and not somewhere else). However, with nouns it is usually used in conjunction with dispela before the noun in contrast to such phrases as long hap there, i stap klostu there (nearby), e.g., long dispela pati hia at this party (here); long dispela pati long hap at that party (over there); long dispela pati i stap klostu at that party (nearby). Finally, hia may be appended to em that as em hia that's the one in answer to questions like Where is it?

${ }^{4}$ Note the use of olsem wanem how come or why. Bilong wanem could just as well have been used.

${ }^{5}$ Note the difference between namba wan first, namba tu second, etc. (which have already been introduced in section 4.2 above) and the compounds (stressed on the first syllable) nambawan first rate, very good, best; nambatu second rate, not so good, inferior. For example:

Namba wan kaikai i kam!

Serve the first course!

Dispela kaikai i nambawan. This food is tops.

6 Klosap may be preferred here in some areas, e.g. Klosap ol i paitim g i ta.

7 The three traditional musical instruments heard throughout this unit come from the kabaul area, New Britain. They are:

a. A Laulau or two note xylophone. The player rests two short sticks on his lap. On these he beats out rhythmical patterns with a hardwood striker held in each hand. The laulau has a variety of uses, including making love spells and musical sorcery. [Sheridan (1.958: side 2, track 4, item a)] 
b. Ding Ding or primitive zither or dulcimer, made from a single segment of green bamboo. Two strings are cut from the bamboo ring. These are tapped lightly into sound with a thin sliver of bamboo. In its most formal use it is sounded with other small instruments at death rites. Nowadays it survives mostly as a love charm. [Sheridan (1958: side 2, track 4, item b)]

c. A Papuanga or child's musical toy, made from a coconut leaf encasing a vibrating reed. This is fastened to a thin stick and whirled into sound around the player's head. Here a boy makes up rhythms to an impromptu mime dance. [Sheridan (1958: side 2, track 4, item c)]

The laulau music is heard separating the conversation exercises; the ding ding, the vocabulary exercises; and the papuanga, the grammar sections.

\section{USEFUL EXPRESSIONS}

Yu save dring bia?

Mi save.

Yu spakman?

Nogat, mi no spakman. Sampela taim tasol mi save spak long bia.

Mi go nau, ai bilong mi i raun.

Kisim wanpela meri buka ${ }^{1}$ i kam! Kisim kol wara ${ }^{2}$ i kam.
Are you a drinker? (as distinct from a teetotaller)

Yes I am.

Are you a drunkard?

No, I'm not. only sometimes I get high on beer.

I'm off now, I'm giddy (i.e., had sufficient to drink)

Bring me a rum.

Bring a drink.

\section{VOCABULARY EXPANSION EXERCISES}

\section{Exercise 1: Simple Substitution}

Frame: Taim em i kamap long pati em i lukim sampela wantok bilongen.

$\begin{array}{ll}\begin{array}{ll}\text { go sutim kapul } \\ \text { baim gras bilong kumul }\end{array} & \begin{array}{l}\text { (to hunt cuscus/possum) } \\ \text { (buy Bird of Paradise } \\ \text { feathers) }\end{array} \\ \text { spak long pati } & \text { (get high at a party) } \\ \text { tambuimgaden } & \text { (put a taboo on the garden) } \\ \text { sapim kanu } & \text { (carve/shape a canoe) } \\ \text { kamap long pati } & \end{array}$

$l_{\text {meri buka }}=$ rum, but literally Zady very black. This form derives from the practice of naming the drink after the picture of a negro woman on the label of a very popular variety of rum, Rhum Negrita, drunk in Papua New Guinea.

${ }^{2}$ kol wara $=$ tok pilai for beer or any alcoholic drink.

3 In some areas go lukautim is also heard for to hunt. 


\section{Exercise 2: Simple Substitution}

Frame: Yu laik i mekim wanem samting long pati hia?
dispela pati
(this party)
dispela pati hia
(this particular party)
stua hia
(this store--not the hospital or any other place)
dispela stua i stap long hapl
(that store over there)
dispela stua i stap longwe
(that store away over there)
dispela stua i stap klostu
(this store nearby)
ol dispela stua hia
(these particular stores
pati hia

Exercise 3: Simple Substitution

Frame: Nogat, mi kam nating ${ }^{2}$ tasol.

bilas nating
pret nating
taitim bun 3 nating
mekim nating
kisim nating
wok nating
stap nating
kam nating
(dress up, decorate for no reason)

(afraid for no reason)

(stretch for no reason)

(do something for no reason)

(take for no reason; unintentionally; free)

(work in vain)

(to be without work; be unmarried)

\footnotetext{
${ }^{1}$ In the Highlands especially this is often shortened to dispela stua lohap.

2 Note that nating also can be used after nouns and adjectives in Pidgin:

bokis nating just a box; an empty box

pipia nating just so much dirt; worthless

bun nating just skin and bone; emaciated

kanaka nating just an ordinary native--not an official

3 Compare also:

taitim skru to tighten a screw, bolt

taitim skin long kundu to tighten the skin on a drum

taitim rot to hurry (stride out) on a journey.
} 
Exercise 4: Simple Substitution

Frame: Em i namba wan taim tru mi kam long pati long Mosbi.

namba ten taim tru

namba tu taim

namba seven taim

namba wan taim tru

Exercise 5: Simple Substitution

Frame: Dogare i putim klinpela siot na trausis.

\begin{tabular}{|c|c|}
\hline $\begin{array}{l}\text { pasim nupela laplap } \\
\text { rausim kolsinglis }\end{array}$ & $\begin{array}{l}\text { (put on loincloth) } \\
\text { (took off sweat shirt) } \\
\text { sweater) }\end{array}$ \\
\hline $\begin{array}{l}\text { samapim siot i bruk } \\
\text { ainim klos bilong slip } \\
\text { bilasim paspas bilong pes } \\
\text { putim klinpela siot na tra }\end{array}$ & $\begin{array}{l}\text { (sew up torn shirt) } \\
\text { (iron pyjamas) } \\
\text { (decorate headband) } \\
\text { usis }\end{array}$ \\
\hline
\end{tabular}

Exercise 6: Simple Substitution

Frame: Bipo long tenpela yia samting pasin bilong mipela i no stap olsem.

$\begin{array}{ll}\text { bipo tru } & \text { ( Zong ago) } \\ \text { longtaim bipo } & (\text { Zong ago) } \\ \text { long taim bilong tumbuna } & \begin{array}{c}\text { (in the time of our } \\ \text { ancestors) }\end{array}\end{array}$

long dispela yia 1930 i (in 1930)
gopinis

(Zong ago)

bipo yet

ting

Exercise 7: Simple Substitution

Frame: Dogare i amamas tru long olgeta samting i stap insait long pati.

klostu long haus

(near the house)

namel long tebol

(in the middle of the table)

bihain long sia

(behind the chair)

ananit long bokis

(under the box)

arere long bokis

(besidelalongside the box)

namel long mitupela

(between us (excl.))

bipo long haus

(in front of the house)

abrus long olgeta

(apart from all the others)

antap long tin

(on top of the tin)

insait long pati 


\title{
6.1 PRONOUNS: OLGETA FORMS
}

When reference is made in Pidgin to all of the participants in an action the adjective olgeta $a l l$ is placed after the pronouns mipela, yumi, yupela, and em. Thus the set of pronouns presented in the preceding units should now be expanded to include the following:

\section{Pidgin Refers to}

English

mipela olgeta the speaker and all those with him but not including the person spoken alz of us (excl.) to

yumi olgeta the speaker and all those with him together with the person spoken to

yupela olgeta all of the persons spoken to

em olgetal all of the persons or things spoken about

\author{
all of us (incl.) \\ alz of you \\ all of them
}

Practice Drills

\section{Exercise 1: Simple Substitution}

Frame: Yupela olgeta i spak long pati.

(yutupela, yumi olgeta, yumifoapela, em olgeta, emtupela, mipela olgeta, mitripela, yupela olgeta)

Exercise 2: Repeat the following sentences substituting the olgeta form of the pronoun for the dual and trial ones used.

1. Emtripela i no sindaun nating.

(pause)

Em olgeta i no sindaun nating.

2. Mi no pret long yutupela.

(pause)

Mi no pret long yupela olgeta.

3. Bai mitripela i bilasim haus bilong papa bilong mi. (pause)

Bai mipela olgeta i bilasim haus bilong papa bilong mi.

4. Dispela meri hia i singaut long emtupela long hap. (pause)

Dispela meri hia i singaut long em olgeta long hap.

5. Masta $i$ wetim yumitripela.

(pause)

Masta i wetim yumi olgeta.

\section{Evaluation Exercise}

Answer the following questions using the cues provided. You may have to make more than one change in some sentences.

1. Emtripela i go we? (long dispela ples i stap kostu) (pause)

Emtripela i go long dispela ples i stap klostu.

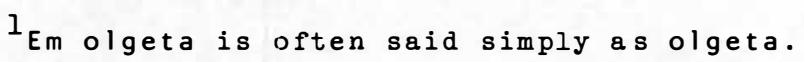


2. Haumas taim yupela olgeta i lukim Ostrelya?

Tripela taim mipela olgeta i lukim Ostrelya.

( tripela taim)

(pause)

( long Bipi)

(pause)

Mipela olgeta i stap long Bipi na mipela i kam.

4. Long wanem taim yu lukim mipela olgeta? (long foaklok samting)

Long foa klok samting mi lukim yupela olgeta.

(pause)

5. Em olgeta i mekim wanem?

Em olgeta i taitim bun.

6. Husat i save sutim pisin long banara?

Mipela olgeta i save sutim pisin long banara.

(taitim bun) (pause)

(mlpela olgeta)

(pause)

\subsection{BEGINNING RELATIVE CLAUSES (who, which, that)}

Relative clauses in English are those parts of sentences which begin with who, which or that. For example, in the sentence I saw the dog that chased my pig the underlined part is a relative clause.

These clauses come from sentences that have been foined or added to other sentences in a special way. Any sentence can be made into a relative clause and incorporated into another provided it contains a noun or noun phrase common to another. For example, either of the two sentences:

1a. I saw the dog and

1b. The dog chased my pig

can be relativised and incorporated into the other because they both have the noun phrase the dog in common. Thus we could have:

1c. I saw the dog that chased my pig or

1d. The dog that I saw chased my pig.

In Pidgin one can do the same thing although there are no markers like who, which or that that have to be remembered. All that happens is that the common noun or noun phrase becomes em (for singular) and em ol (for plural).l For example, suppose one wants to express the following two ideas in the one sentence:

\section{2a. Mi lukim dok I saw the dog}

2b. Dok i ranim pik bilong mi The dog chased my pig

then this would normally be done as follows:

2c. Mi lukim dok em i ranimpikbilong mi

in which the relative clause em i ranim pik bilong $m i$ is derived from sentence $2 \mathrm{~b}$. Again, if the sentences had been:

3a. Mi lukim ol dok I saw the dogs and

3b. 01 dok i ranim pik bilong mi The dogs chased my pig in which ol dok is plural then these would normally be joined as follows :

3c. Mi lukim ol dok em ol i ranimpik bilong mi.

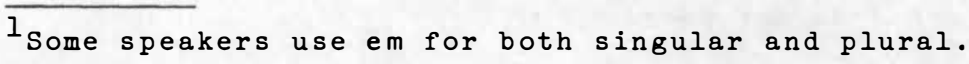


Note, however, that the sentences $2 a-2 b$ and $3 a-3 b$ could have been Joined as follows:

2d. Dok mi lukim em, em i ranimpik bilong mi.

3d. 01 dok mi lukim em, (em) ol i ranim pik bilong mi.

though this kind of joining is less common than that used for the $2 \mathrm{c}$ and $3 \mathrm{c}$ counterparts given above. Note further, however, that when the relative clause appears as the subject (as it does in $2 d$ and $3 d$ ) then it is usually followed by the pronouns em (if it is singular) or (em)ol (if it is plural). The reason for this is that when subjects are long in Pidgin they are generally repeated as pronouns (em, or (em)ol). Here are some more examples:

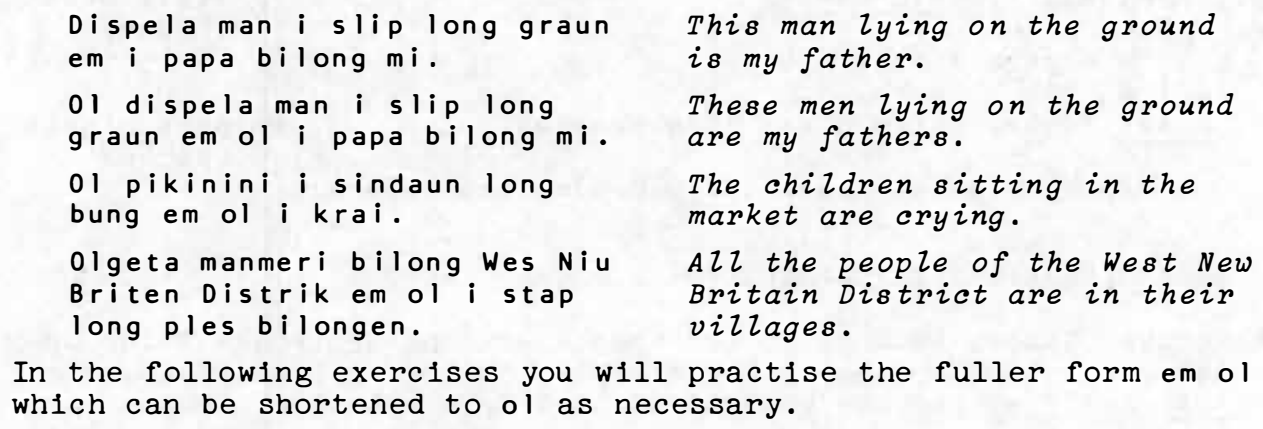

In the following exercises you will practise the fuller form em ol which can be shortened to ol as necessary.

Practice Drills

Exercise 1: Simple Substitution

Frame: Mi lukim dok em i ranim pik bilong mi.

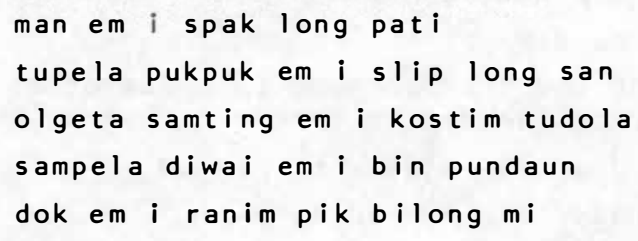

\section{Exercise 2: Simple Substitution}

Frame: 01 i soim mi trak mipela i wetim em.

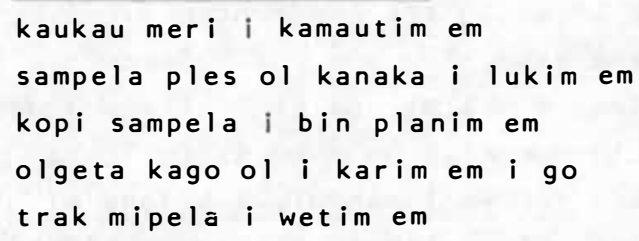

Exercise 3: Simple Substitution

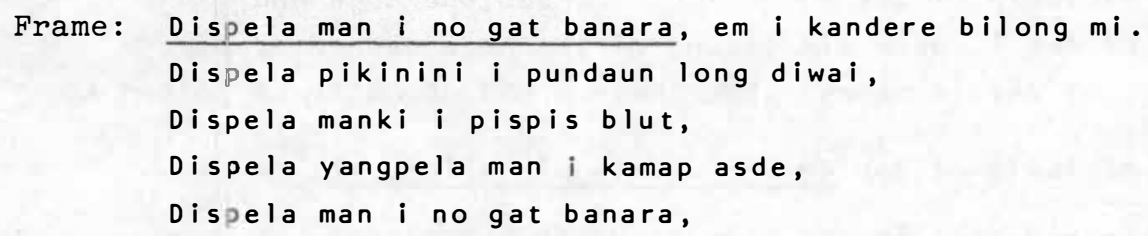




\section{Exercise 4: Simple Substitution}

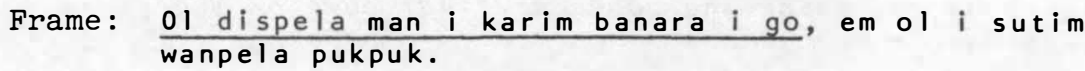

01 dispela masta i kamap asde,

olgeta manki $i$ sindaun nating,

01 dispela pikinini i wokabaut long rot,

01 dispela man i karim banara i go,

Exercise 5: In this exercise you will hear pairs of sentences ident1fied by numbers and the letters ' $a$ ' and ' $b$ '. Insert the second or ' $b$ ' sentence into the first or ' $a$ ' sentence as a relative clause. Ready?

la. Mama bilong mi i soim mi bikrot.

1b. Bikrot i go long taun.

(pause)

Mama bilong mi i soim mi bikrot em i go long taun.

2a. Tupela wantok i lukim kakaruk.

2b. Dok i kaikai kakaruk.

(pause)

Tupela wantok i lukim kakaruk dok i kaikai em.

3a. Olgeta pikinini i krai.

3b. Olgeta pikinini i sindaun long bung. (pause)

olgeta pikinini i sindaun long bung em ol i krai.

4a. Dogare i pasim nupela laplap.

4b. Em i baim nupela laplap long Stimsip. (pause)

Dogare i pasim nupela laplap em i baimem long Stimsip.

5a. Dispela man i papa bilong mi.

5b. Dispela man i slip long graun.

(pause)

Dispela man i slip long graun em i papa bilong mi.

Exercise 6: Add em or em ol after the subject in the following sentences:

1. Wanpela pikinini man bilong mi (em) i save tok lnglis. (pause)

2. 01 kakaruk i gat lek i bruk (em ol) i no save wokabaut.(pause)

3. Olgeta manmeri bilong Wes Niu Briten Distrik (em ol)

i stap long ples bilong ol.

(pause)

4. Asde etpela liklik balus (em ol) i pundaun long Wewak. (pause)

5. 01 tis bilongen (em ol) i lait nau.

(pause)

\section{Evaluation Exercises}

Exercise 1: Repeat the following sentences and then say what they mean in English:

1. Bai em i baim wanpela taksi em i gat wailis longen. (pause) He'zl buy a taxi which has a wireless in it. 
2. Yu ting wanem? Kago i kam long balus asde em i stap we? (pause) Where do you think the goods are that came on the plane yesterday?

3. Tupela wantok i lukim kakaruk em i sindaun long banis. (pause) Two friends see the fowl sitting on the fence.

4. Papa bilongen em i man yu toktok wantaim em bipo.

(pause)

His father is the man you talked with some time ago.

5. Mi no laik i baim bas em i go bek long taun.

(pause)

I don't want to catch the bus that is returning to town.

Exercise 2: How would you say the following things in P1dgin?

1. This money which is beside the box is ours (excl.)

(pause)

Dispela mani i stap arere long bokis hia, em i bilong

mipela.

2. Did you see those boys who were standing apart from all (pause) the others or not?

Yu lukim ol dispela manki em ol i sanap abrus long olgeta arapela o nogat?

3. All the boys who fell off the truck are unconscious ${ }^{l}$ in (pause) the hospital.

olgeta manki i pundaun long trak, em ol i dai long haus sik.

4. Some people who live in the Central District want to plant pitpit.

(pause)

Sampela manmeri i stap long Sentral Distrik em ol i laik i planim pitpit.

5. Where is that box which has money in it?

(pause)

Dispela bokis em i gat mani insait longen, em i stap we?

\subsection{ADJECTIVES (-pela Forms)}

The typical adjective in Pidgin ends in pela and comes before the noun, e.g., bikpela maunten big mountain, yangpela meri young native woman. However, these can also be used as predicates of sentences after i, e.g., maunten i bikpela the mountain is big; meri i yangpela the native woman is young. ${ }^{2}$ At such times most retain the pela but there are some which do not. Note also that there are some pairs of adjectives which have the same form when they come before the noun but different forms--one with and one without -pela--when they occur as predicates. The following sets illustrate.

Set 1: Adjectives which retain -pela in Predicative Position
Dispela i bikpela haus.
Dispela haus i bikpela.
(big)
Dispela i gutpela kaikai.
Dispela kaikai i gutpela.
(good)
Dispela i longpela diwai.
Dispela diwai i longpela.
(Zong)

\footnotetext{
${ }^{1}$ Remember da $i=$ to be winded, unconscious, numb, asleep (as of parts of the body) and dai pinis= die, cease to live.

2 In fact this form is generally used when there are two adjectives in a sentence, e.8., Mi lukim dispela blakpela pik i draipela $I$ saw that huge black pig.
} 


$\begin{array}{llll}\text { Dispela i blakpela pik. } & \text { Dispela pik i blakpela. } & \text { (black) } \\ \text { Dispela i raunpla ston. } & \text { Dispela ston i raunpla. } & \text { (round) } \\ \text { Dispela i hatpela ston. } & \text { Dispela ston i hatpela. } & \text { (hard) } \\ \text { Dispela i draipela pik. } & \text { Dispela pik i draipela. } & \text { (Zarge, fat) } \\ \text { Dispela i strongpela diwai. } & \text { Dispela diwai i strongpela. } & \text { (strong) } \\ \text { Dispela i stretpela pos. } & \text { Dispela pos i stretpela. } & \text { (straight) }\end{array}$

Set 2: Adjectives which lose -pela in Predicative Position

$\begin{array}{lll}\text { Dispela i klinpela trausis. } & \text { Dispela trausis i klin. } & \text { (clean) } \\ \text { Dispela i kolpela wara. } & \text { Dispela wara i kol. } & \text { (cold) } \\ \text { Dispela i hatpela wara. } & \text { Dispela wara i hat. } & \text { (hot) } \\ \text { Dispela i sappela spia. } & \text { Dispela spia i sap. } & \text { (sharp) } \\ \text { Dispela i stretpela man. } & \text { Dispela man i stret. } & \text { (honest) } \\ \text { Dispela i stretpela tok. } & \text { Dispela tok i stret. } & \text { (in } i n e) \\ \text { Dispela i draipela siot. } & \text { Dispela siot i drai. } & \text { (dry) } \\ \text { Dispela i strongpela masta. Dispela masta i strong. } & \text { (stubborn) }\end{array}$

Set 3: Adjectives which have two forms in Predicative Position

Dispela i hatpela kaikai. Dispela kaikai i hat. (hot)

Dispela i hatpelakaikai. Dispelakaikai i hatpela. (hard) ${ }^{1}$

Dispela i draipela klos. Dispela klos i drai. (dry)

Dispela i draipela klos. Dispela klos i draipela. (Zarge, fat)

Dispela i strongpela masta. Dispela masta i strong. (stubborn)

Dispela i strongpela masta. Dispela masta i strongpela. (strong)

Dispela i stretpela man. Dispela man i stret.

Dispela i stretpela man. Dispela man i stretpela. (well postured, straight)

Practice Drills

Exercise 1: Repeat the following (above) sets of sentences after the instructor. Ready?

Exercise 2: Change the following sentences into ones in which the adjective appears in the predicate. These are all ones which do not change form. English cues are provided to remind you of the meaning of each adjective. Ready?

1. Dispela i longpela man.

(Zong) (pause)

Dispela man i longpela.

2. 01 i draipela pik.

(Zarge) (pause)

01 pik i draipela.

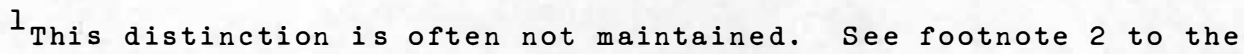
Conversation in Unit 9 . 
3. Olgeta i strongpela diwai.

(strong) (pause)

olgeta diwai i strongpela.

4. Dispela i retpela kaukau.

(red)

(pause)

Dispela kaukau i retpela.

5. 01 i hatpela ston.

(hard) (pause)

01 ston i hatpela.

Exercise 3: Change the following sentences into ones in which the adjective appears in the predicate. These are all ones which change form. English cues are provided to remind you of the meaning of each adjective. Ready?

1. 01 dispela i kolpela ti. (cold) (pause)

01 dispela ti i kol.

2. Dispela i stretpela man bilong Sepik.

(honest) (pause)

Dispela man bilong Sepik i stret.

3. 01 dispela i draipela siot.

$(d r y) \quad$ (pause)

01 dispela siot i drai.

4. Dispela i strongpela meri.

(stubborn) (pause)

Dispela meri i strong.

5. Dispela i hatpela paia.

(hot)

(pause)

Dispela paia i hat.

\section{Evaluation Exercises}

Exercise 1: Say what the following sentences mean in English:

1. Dispela haus long hap i gutpela.

(pause)

That house over there is good.

2. Kaikai bilongen i hat o nogat?

(pause)

Is his food hot or not?

3. Yu kisim i kam ol siot i drai.

(pause)

Bring the shirts which are dry.

4. 01 dispela meri i stret, em ol i stap we?

(pause)

Where are those women who are honest?

5. Yupela i inap karim i kam ol dispela raunpela (pause) ston?

Are you (pl.) able to bring these round stones? 
Exercise 2: Repeat the following sentences changing the adjective to the one corresponding to the English one given as cue:

1. Dispela haus i gutpela. (strong) (pause)

Dispela haus i strongpela.

2. Kaikai bilongen i hat o nogat?

(cold) (pause)

Kaikai bilongen i kol o nogat?

3. Yuklsim i kam ol siot i drai.

(red)

(pause)

Yu kislm i kam ol siot i retpela.

4. 01 dispela meri i stret em ol i stap we? (fat)

(pause)

01 dispela meri i draipela em ol i stap we?

5. Yupela i inap karim i kam dispela gutpela man?

(stubborn) (pause)

Yupela i inap karim i kam dispela strongpela man?

\subsection{KLOSTU + VERB: about to, nearly, almost}

Verbs preceded by $k$ lostu (or $k$ losap in some areas) denote actions about to take place, or ones nearly or almost having taken place--the difference being generally determined by the context, e.g.,

Klostu ol i paitlm gita.

01 klostu i paitlm gita.

They're about to play guitars.

Klostu mi pundaun.

?Mi klostu i pundaun.

I nearly fell down or I'm about to fall down.

Dispela haus klostu i pundaun. The house is nearly falling

Klostu dispela haus i pundaun.' down/nearly fell down.

Note that klostu does not immediately precede the verb (as inap does) but like the future marker bai pivots around the subject. In general klostu may come before or after the subject though for short subjects the tendency is for it to come before. There is, however, one important exception and that is for subjects containing adjectives of number like olgeta, tenpela, etc. In those cases klostu must come after the subject if the wrong interpretation is to be avolded. Compare for example:

$$
\begin{array}{ll}
\text { Klostu olgeta haus in pundaun. } & \text { Nearly all the houses are } \\
& \text { falling down. } \\
\text { olgeta haus klostu i pundaun. } & \text { All the houses are nearly } \\
& \text { falling down. }
\end{array}
$$

Klostu may of course be used after the verb and with long with meanings of nearby and near, e.g.

$$
\begin{array}{ll}
\text { em i stap klostu } & i t^{\prime} s \text { nearby } \\
\text { em i stap klostu long haus } & i t^{\prime} s \text { near the house }
\end{array}
$$


Practice Drills

Exercise 1: Simple Substitution

Frame: Klostu ol i paitimgita.

(go sutim kapul; kam; sindaun gen; pasim stua; rausim pipia; paitim gita)

\section{Exercise 2: Simple Substitution}

Frame: Bai mi stilim klostu olgeta mani.

$$
\text { (bungim, kisim, lusim, painim, stilim) }
$$

\section{Evaluation Exercise}

Repeat the following sentences and say what they mean in English:

1. 01 manmeri klostu i go long haus lotu.

(pause)

The people are about to go to church.

2. Klostu olgeta pasindia i sanap wetim bas.

(pause)

Nearly all the passengers are standing waiting for the bus.

3. Wewak i stap klostu long wara Sepik.

(pause)

Wewak is near the Sepik River.

4. Klostu olgeta balus i pundaun long Lae.

(pause)

Nearly all the planes land at Lae.

5. Klostu em i kirapim wok.

(pause)

He's about to begin work.

\section{TEXT}

Here is a story about a party at the Ex-Servicemen's Club, Dreikikir by a young man (aged about twentytwo) from Musingwik, near Dreikikir. Listen to it and then see if you can translate 1t. Here is the story:

Mi laik stori long dispela pati i bin kamap long Eksevismen Klab long Dreikikir. Em long las wik Fraide--eh, dispela wik Fraide. Planti manmeri ol i bin kamap long pati na tu insait long dispela pati ol i bin katim wanpela kau ${ }^{l}$ na ol i salim, bilong ol man long pati na ol pikinini na meri em ol i bin i kam long pati em ol i baim. ${ }^{2} \mathrm{Na} t u$ i bin i gat tripela tim olgeta, ol i bin pleim insait long dispela tim. Em tim hia: Tumam, Yumbarengor, na tu Yambes. 01 tripela pilai gita singsing olgeta ol i sindaun na ol i bin sikerapimgita ${ }^{3}$

\footnotetext{
$l_{\mathrm{kau}}=\mathrm{bulmakau}$

${ }^{2}$ The sense here is puzzling. It is not clear to me whether ol man
} 
means everybody or just the men.

3sikerapim gita = to strum a guitar

na olgeta man i bin danis. ${ }^{1}$ Na tu klab i bin i stap klostu na planti man moa ol i bin spak insait long klab. Na ol i bin amamas moa-planti kaikai tu long nait--ol i baim rais samting long nait. 01 i bin salim kau, long wanpela hap kau long seven klok tu twelv klok, na long wan klok yet ol i bin salim narapela tu.inap long sikis klok long moning. Pati i bin $i$ go gut moa na planti manmeri moa ol i bin amamas tru long dispela pati inap long sikis klok long moning. Na tu insait long dispela pati em $i$ olsem ah--klab em i bin singautim dispela--baim dispela kau bilong singautim ol manmeri bllong kam na baim dispela kau long kisimmoa mani i go insait long klab. Na tu ol planti ol ${ }^{2}$ man na meri na ol P.M.v. bilong sampela hap bilong Maprik tu ol i bin kam antap ${ }^{3}$ na mamel long Maprik na Dreikikir ol i bin $i$ kam antap long dispela pati, na planti long yumi ${ }^{4}$ long hia ${ }^{5}$ ol i bin i go long dispela pati. Pati i bin i stap inaplong sikis klok moning. Em tasol. Em stori bilong pati em mi bin toktok long yupela.

[Playing time: 2 minutes]

ENGLISH TRANSLATION:

I'm going to tell about the party which was held at the ExServicemen's Club, Dreikikir. That was on Friday of last week--ah, on Friday of this week. Many people came to the party. Moreover, $a$ bullock was cut up and sold for everybody/the men (?) at the party and the children and women who had come to the party bought it. As well there were three groups altogether who played as a band (lit. in this groupl. These were: Tumam, Yumbarengor, and also yambes. These three groups played all guitar music. They sat down and played guitars and everyone danced. And the bar (lit. the club) was nearby too (i.e., the bar of the club was near the dancing area) and very many men were intoxicated (lit. high) and very merry there. (There was) plenty of food too during the night. They bought rice and other

$I_{\text {danis }}=$ to dance (non-traditionally)

2 ol planti ol. Note use of the two ol's here. According to Mr. P. Mühlhäusler there is a lot of uncertainty about the use of ol as a plural marker in the area where these stories were recorded.

3 antap refers to Dreikikir.

4 From context one would have expected mipela here.

$5_{h i a}$ refers to Musingwik. 
things and sold beef--one half of a bullock between seven o'clock and midnight and the other between one and six a.m. The party really went well and very many folk were very happy right through until six a.m. Moreover, inside this party it was like this--ah--the club called out for this--bought this bullock in order to get everyone to come (lit. call out for the people to come) and buy this bullock (so as) to get more money for the club. And also plenty men and women and P.M. $V$. 's from around about Maprik and from between Maprik and Dreikikir came (up) to Dreikikir, too. And plenty of our (Musingwik) people went (too). The party went through (the night) until six a.m. That's all. That's the story about the party which I have spoken to you about.

Now to end this tape here is another Pidgin song. The background to this song is as follows:

Dispela singsing em wanpela man em i bin wokaut (?) long

tingting bilongen long em i--wanpela gelpren bilongen $i$

bin lusim em na dispela gelpren bilongen tekim narapela

boi na dispela gelpren bilongen em i sotpela na dispela

boipren bilong em em i longpela. Na long taim em i go

sanap long em--draiwara arau (2) em i singim dispela sing-

sing nau:

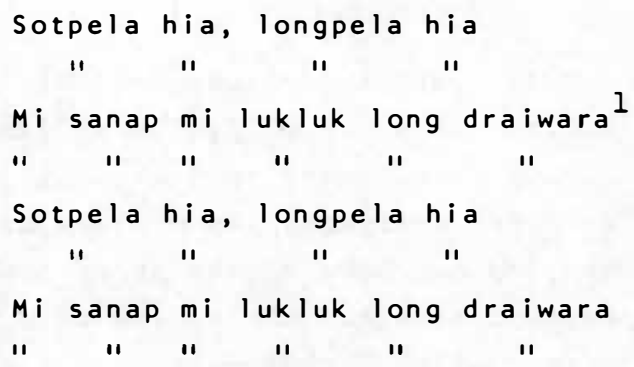

\section{SUPPLEMENTARY VOCABULARY}

\begin{tabular}{ll}
$\begin{array}{l}\text { bilum (bilong man/meri) } \\
\text { basket }\end{array}$ & $\begin{array}{l}\text { (man's/woman's) netbag; any woven material } \\
\text { basket } \\
\text { laplap }\end{array}$ \\
loincloth \\
paspas & $\begin{array}{l}\text { any band (usually woven) } \\
\text { paspas bilong han }\end{array}$ \\
paspas bilong lek & anklet \\
paspas bilong bel; let belt & grass skirt \\
purpur/pulpul & skirt (European type) \\
siket & \\
\hline ldraiwara here equals draipela wara big water or ocean.
\end{tabular}




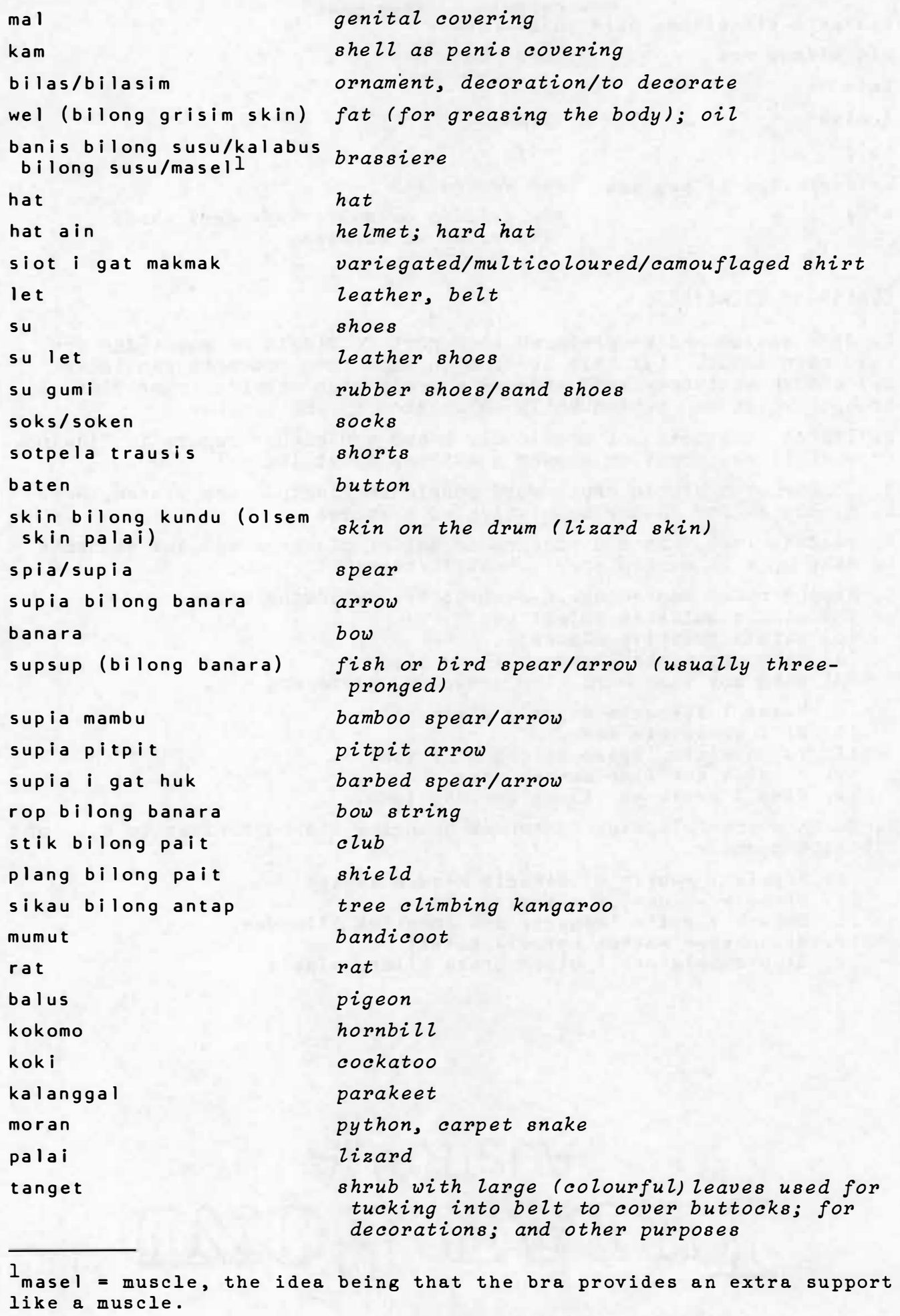

$l_{\text {masel }}=$ muscle, the idea being that the bra provides an extra support like a muscle. 


$\begin{array}{ll}\text { blakpela sit bilong paia black ashes } \\ \text { pin bilong nus } & \text { nose pin } \\ \text { akis } & \text { axe } \\ \text { tomiak } & \text { tomahawk } \\ \text { naip } & \text { knife } \\ \text { kalang/bilas bilong yau ear decoration } \\ \text { kina } & \text { the goldlip or mother-of-pearl shell } \\ & \text { important as currency }\end{array}$

\section{CLASSROOM EXERCISES}

1. Read Wantok and be prepared to report in Pidgin on something you have read about. [If this is done on tape then students can later write down what they said and can correct each other's transcript, both of which can subsequently be checked by the teacher.]

2. Listen to a text not previously heard and either report in Pidgin on what it was about or answer questions about it.

3. Construct a simple cross-word puzzle in Pidgin. See Wantok, Nos. $6,8,10,44$ for rather sophisticated examples.

4. Picture Talk. Show a picture or set of pictures and ask students to make up a connected story about 1 t/them.

5. Expand these sentences in each of the following ways:

(a) with a suitable adjective;

(b) with a relative clause;

(c) with any number between 1 and 16;

(d) with any time word like tomorrow, yesterday etc.

1. Husat i lukautim dispela pikinini?

11. 01 i go painim kanu.

111. Yu go kisim laplap bilong mi i kam!

iv. Dispela dok i no pekpek blut.

v. Kiap i redim ka bilong go long taun.

6. Restate the following sentences changing the adjectives to ones of opposite meaning:

1. Yupela i rausim ol bikpela kiau o nogat?

11. Dispela su gumi i gutpela.

111. Dogare i putim longpela sok long lek bilongen.

1v. Mi no save kaikai hatpela kaikai.

v. 01 blakpela man i olsem brata bilong mipela. 


\title{
UNIT 7
}

CONVERSATION

\author{
Long Opis \\ Long Mande Dogare i kam bek gen \\ On Monday Dogare went back to the \\ long opis bilong kampani masta. \\ office of the manager of the firm. \\ Masta i lukim em na i singaut \\ The manager saw him and called out \\ long em i kam insait long opis. \\ to him to come inside. \\ Masta: Yu kolim nem bilong yu! What's your name? \\ Dogare: Nem bilong mi, Dogare. My name is Dogare. \\ Masta: Yu marit? \\ Are you married? \\ Dogare: Nogat, mi no marit; mi \\ No. I'm single. \\ stap nating. \\ Masta: Tasol yu slip we? \\ But where do you sleep? \\ Dogare: Mi slip wantaim brata \\ With my brother in Boroko. \\ bilong mi long Boroko. \\ Why? \\ Dogare: Bilong wanem $m i$ no gat \\ Because I don't have a house of \\ haus bilong mi yet. \\ my own yet. \\ Masta: Yu gat haumas krismas? \\ How old are you? \\ Dogare: Mi no save. Ating $\mathrm{mi}$ \\ I don't know. Probably about \\ gat samting olsem tupela \\ twentysix. \\ ten sikis. \\ Masta: Orait, nau yu ken i go \\ na kirapim wok. ${ }^{l}$ \\ Al2 right you can go and begin \\ work now. \\ Dogare: Tasol masta, bai mi \\ But sir, where shall I dig the \\ wokim baret we? \\ trench? \\ ${ }^{1}$ Kirapim can mean either to start or begin (something) as in kirapim \\ skul begin school or to wake someone up as in Yu kirapim ol slipman \\ Wake up the sleepers! Note, however, the difference between kirapim \\ to begin, start something and kamapim to create, originate something. \\ Compare, for example, ol i kirapim singsing they are beginning the \\ dance and dispela man hia em i kamapim dispela nupela singsing this \\ man created this new dance.
}


Masta: Yu wet! Bai mi singautim Hold on! I'll call out to the bosboil ${ }^{l}$ i kam soim yu. overseer to come and show you. Nogut yu wokim baret kranki. It'd be a waste if you dug it incorrectly.

Bihain bosboi i kam givim spet Later the overseer came and gave na kroba long Dogare na soim em ples bilong kirapim wok. Dogare a spade and crowbar and showed him the place to begin work.

\section{[Musik ${ }^{2}$ ]}

\section{USEFUL EXPRESSIONS}
Mi no marit. Mi stap nating.
I'm not married. I'm single/a
Ating mi lus tru long ol meri. bachelor.
Mi maritman (or maritmeri).
I guess I've missed the boat as far as women are concerned.
Mi marit nating. Mi no marit I'm a married man/woman. long haus lotu.
I married according to our custom. I did not marry in a church.

\section{VOCABULARY EXPANSION EXERCISES}

\section{Exercise 1: Simple Substitution}

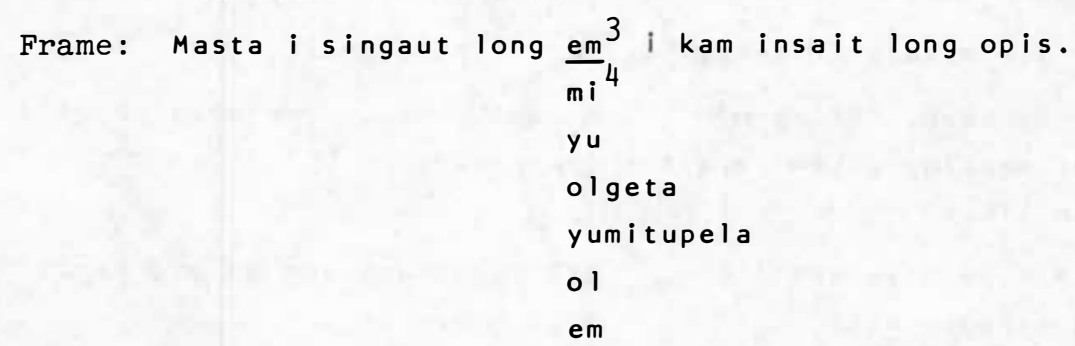

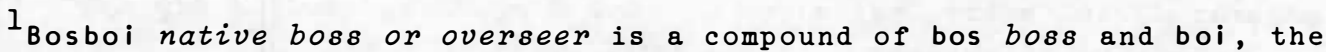
ubiquitous (though now offensive) term for any male native in New Guinea irrespective of age. European bosses or overseers are simply referred to as masta or masta plus personal name (see Unit 5, footnote 3). Relative rank in power amongst overseers would be indicated by using the adjectives namba wan, namba tu etc. Note that both bos and bo i appear frequently in other compounds, most of which are given in the supplementary vocabulary list to this unit.

2 The traditional music heard on this tape is called witainwaluna. It is a song of mourning by the eldest son after the burial of his mother. This recording comes from Sheridan (1958: side 1, track 5, item a).

${ }^{3}$ Note that em here is not shortened to en after long because it is subject of the clause em $i$ kam insait long opis.

4 Note that $m i$ and $y u$ "take" the predicative marker $i$ in sentences like these. See Section 12.4 .
} 


\section{Exercise 2: Simple Substitution}

Frame: Yu kolim nem bilong yu!

\begin{tabular}{ll}
\hline raitim nem & (write) \\
ritimnem & (read) \\
spelim nem & (spell) \\
raitimpas & (writea letter) \\
wokim pas & (compose a letter) \\
adresim skin pas & (address an envelope) \\
autim tok hait & (divulge a secret) \\
kolim nem &
\end{tabular}

\section{Exercise 3: Simple Substitution}

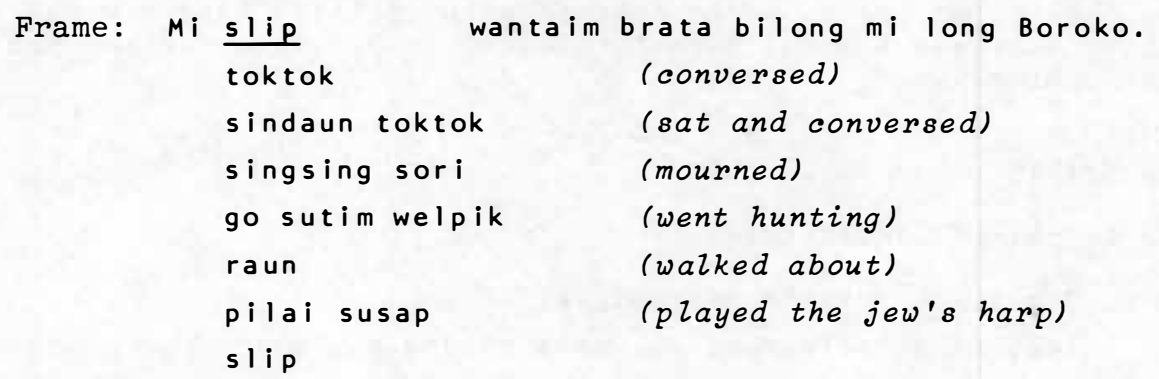

\section{Exercise 4: Simple Substitution}

Frame: Orait, nau yu ken i go na kirapim wok.

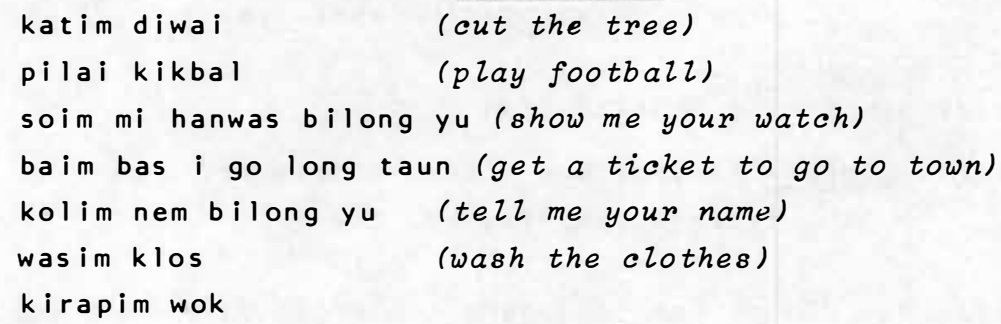

\section{Exercise 5: Simple Substitution}

Frame: Nogut yu wokim baret kranki.

$$
\begin{aligned}
& \text { sindaun nating (sit in vain) } \\
& \text { bagarapim olgeta samting bilong } \mathrm{mi} \text { (destroy) } \\
& \text { karamapim pikinini long sel (cover the child } \\
& \text { with a tarpauline) } \\
& \text { karamapim tok olsem (be vague or deceitfuz) } \\
& \text { sakim tok bilong masta (disobey) } \\
& \text { pasim rot bilong mipela (block) } \\
& \text { kros nating (get angry for no reason) } \\
& \text { wokim baret kranki }
\end{aligned}
$$




\section{GRAMMAR}

\subsection{KEN + VERB: PERMISSION}

Permission to carry out an action is expressed in Pidgin by placing ken before the verb, except for come and go which have the predicative marker i.l Compare, for example,

Yu ken sutim dispela pik.

Yu no ken sutim dispela pik.

Yu ken i go.

Em i no ken i kam.
You may shoot this pig.

you are not allowed to shoot this \{pig!

you must not shoot this pig!

You may go.

She cannot come!

'She must not come!

Note that ken forms are to be contrasted with ability (inap + verb) and competence (save + verb) ones introduced in sections 5.2 and 5.1 above respectively.

Practice Drills

Exercise 1: Simple Substitution

Frame: Orait, ol i ken rausim pipia.

(em, mi, dispela man, yu, mama bilong mi, ol)

\section{Exercise 2: Simple Substitution}

Frame: Yu no ken sutim dispela pik.

(ol, mipela, kiap, yumi olgeta, yu)

\section{Exercise 3: Simple Substitution}

Frame: Tupela tasol i ken i kam wantaim mi.

(em, tripela, yupela, yu, tupela)

Exercise 4: Change the following sentences from ones indicating ability to ones indicating permission to do something. For example, given yu no inap ritim dispela buk your answer should be yu no ken ritim dispela buk. Ready?

1. 01 i inap pilai kikbal.

(pause)

01 i ken pilai kikbal.

2. Mipela i no inap spelim nem bllong yu.

(pause)

Mipela i no ken spelim nembilong yu.

\footnotetext{
${ }^{I}$ In some areas ken $V$ (permission) is distinguished from ken $i v$ (definite future). In others ken $v$ or ken $i v$ is used for both permission and definite future (see Wurm (1971:49-50)). In this course, however, we shall keep them separate though the distinction is neutralized for $i$ go and $i \mathrm{kam}$.
} 
3. Bai emtupela i no inap wokim stua bilong $\mathrm{mi}$.

(pause)

Bai emtupela i no ken wokim stua bilong $\mathrm{mi}$.

4. Yu inap karim dispela bokis i go long ples balus. (pause) Yu ken karim dispela bokis i go long ples balus.

5. Nogat, mi no inap karim em i go.

(pause)

Nogat, mi noken karim em i go.

6. Husat i inap i go?

(pause)

Husat i ken i go?

Evaluation Exercise

Say what the following Pidgin sentences mean. Your answers should indicate that you recognise the difference between ability, competence and permission forms.

1. Yu inap lukim mi?

(pause)

Are you able to see me?

2. Em i save singsing raun olsem ol Tolai?

(pause)

Does he know how to dance Tolai style?

3. Yupela i noken sakim tok bilong kaunsila bilong yupela.

(pause)

\{You (pl.) are not allowed to disobey your councillor.

You (pl.) must not disobey your councillor.

4. Mi no ken kolim nem bilong mi.

(pause)

I'm not allowed to say my name.

5. Dispela man hia em i no save ainim klos.

(pause)

This man doesn't know how to iron clothes.

6. Yutupela tasol i ken i go wantaim em.

(pause)

only you(2) \{ $\begin{aligned} & \text { are allowed to } \\ & \text { may }\end{aligned}$

\subsection{NEgATIVE IMPERATIVES (No, No Ken, Nogut)}

Commands or requests designed to prohibit someone or something from doing something are expressed in one of several ways in Pidgin. 1

One is to negate affirmative commands by placing no between the subject and the verb, e.g.,
Yu go!
You go!
Yu no go!
Don't go!
Yumi go:
Let's go!
Yumi no go!
Let's not go!

${ }^{1}$ See also maski $V$ in Unit 8 and no ken $i v$ in Unit 10. 
Another is to negate permissive sentences just introduced by placing no between the subject and ken V (permission), e.g.,
01 i ken sutim pik.
01 i no ken sutim pik.

They are allowed to shoot the pig.

They're not allowed to shoot the \{pig.

Don't let them shoot the pig.

A third option is to prefix sentences with nogut bad as occurs in the conversation beginning this unit. Compare:

Yu sindaun!

Nogut yu sindaun!

Dok i kaikaim mi!

Yu holim dok! Nogut em i

kaikaim mi!

The different social uses of the se three constructions should be obvious from the examples given.

Practice Drills

Exercise 1: Simple Substitution

Frame: Yu no sindaun nating:

(bagarapim olgeta samting bilongen; pasim stua yet;

kirapim wok; wokim baret kranki; pilai kikbal)

\section{Exercise 2: Simple Substitution}

Frame: Mipela i no ken pilai kikbal.

(karamapim tok obsem; i kam wasim klos; sakim tok

bilong em; katim dispela diwai; sindaun nating)

\section{Exercise 3: Simple Substitution}

Frame: Nogut pik i kam bagarapimgaden bilongmi.

(pekpek long ples bilong ol; brukim graun insait

long gaden; slip insait long haus; bagarapim

gaden bilong $\mathrm{mi}$ )

Exercise 4: Make the following commands negative by inserting no in the correct place. Ready?

1. Yutupela go slip!

(pause)

Yutupela no go slip! 
2. Mipela i ken kolim nem bilong yu.

(pause)

Mipela i no ken kolim nem bilong yu.

3. Yu ken karamapim trak long sel.

(pause)

Yu no ken karamapim trak long sel.

4. Yu paitim susap!

(pause)

Yu no paitim susap!

5. Plen $i$ ken pundaun long dispela ples balus hia. (pause)

Plen i no ken pundaun long dispela ples balus hia.

Exercise 5: Negate the following sentences using nogut.

1. Pikinini i pundaun long diwai.

(pause)

Nogut pikinini i pundaun long diwai.

2. 01 i kros nating.

(pause)

Nogut ol i kros nating.

3. Mipela i go sutim kapul long Sande.

(pause)

Nogut mipela i go sutim kapul long Sande.

4. Dispela meri i stilim hankisip long stua.

(pause)

Nogut dispela meri i stilim hankisip long stua.

5. 0lgeta pasindia i sanap wetim bas long san.

(pause)

Nogut olgeta pasindia i sanap wetim bas long san.

\section{Evaluation Exercises}

Exercise 1: Choosing between no, no ken and nogut say in Pidgin how you would tell someone the following things:

1. How would you tell him that he is not allowed to eat pork?

(pause)

Yu no ken kaikai pik:

2. How would you tell him that it wouldn't be wise for him to eat pork?

(pause)

Nogut yu kaikai pik.

3. How would you tell him not to eat that pork over there?

Yu no kaikal dispela pik long hap.

4. How would you tell him to send his parents a letter;

it wouldn't be good for them to be without anything? (pause)

Yu salim pas $i$ go long papamama bilong yu. Nogut tupela i stap nating.

5. How would you tell him that he is not allowed to shoot Bird of Paradise.

Yu no ken sutim kumul. 
Exercise 2: Repeat the following Pidgin sentences and say what they mean in English.

1. Nogut yupela i kaikai rais nating.

(pause)

you (pl.) shouldn't eat just rice.

\{It's not good for you ( $p$ l.) to eat just rice (i.e.

without meat or something else.

2. Emtupela i no ken lukim dispela dok em i bin kilim

i dai kakaruk bilong mi.

(pause)

Those two are not allowed to see that dog that

killed my fowl(s).

3. Nogut yu karamapim ol siot i no drai yet.

(pause)

you shouldn't cover up shirts that are not yet dry.

'It's not good to cover up shirts that are not yet dry.

4. Yutripela i no ken sapim kanu.

(pause)

you three are not allowed to carve canoes.

5. Nogut pikinini tasol i go sutim welpik long bikbus. (pause)

Children should not go hunting wild pigs in the jungle alone.

'It's not good for only children to go hunting wild

pigs in the jungle.

\subsection{MORE ON VERBS (Stative, $\mathrm{V}+$ long, $\mathrm{V}+\mathrm{im}$ )}

As learners of Pidgin you should now have begun to notice that many verbs in Pidgin are very similar in form and related in meaning though different in use. Consider, for example, the following pairs of verbs which have been introduced so far into the lessons:

$\begin{array}{llll}\text { wok } & \text { to work } & \text { wokim } & \text { to make (something) } \\ \text { wet } & \text { to wait } & \text { wetim } & \text { to wait for (someone) } \\ \text { toktok to converse } & \text { tokim } & \text { to tell (someone) } \\ \text { kirap to arise; get up } & \text { kirapim to begin; start (something) } \\ \text { bilas to be decorated } & \text { bilasim to decorate (something) }\end{array}$

Pidgin has many such verb forms. In general those marked by -im are, as already pointed out in Section 1.2 above, transitive (1.e., they require an object), 1 while those not so marked are intransitive, including some which are generally referred to as stative, e.g., bruk in kap $i$ bruk the cup broke or the cup is broken. Study the following list of verbs paying particular attention to the differences in meaning between the last ten and then proceed to the exercises given below. 2

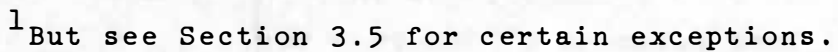

${ }^{2}$ See Wurm (1971:26-31) for more detailed discussion of various possible verb classes in Pidgin.
} 


\begin{tabular}{|c|c|c|c|}
\hline bagarap & $\begin{array}{l}\text { to be or get spoilt, } \\
\text { ruined }\end{array}$ & bagarap Im & to ruin, spoil (obj.) \\
\hline bilas & to be decorated & bilasim & to decorate (obj.) \\
\hline boil & to be boiling & bollim & to boil (obj.) \\
\hline hait & to be hidden & halt Im & to hide (Obj.) \\
\hline bruk & to be broken & bruklm & to break (obj.) \\
\hline op & to be open & op Im & to open $(O b j)$. \\
\hline kamaut & to rme out & kamaut Im & to pulz out (obj.) \\
\hline kapsalt & to overturned & kapsa I t Im & to overturn (obj.) \\
\hline klia & to be clear & klirim ${ }^{1}$ & $\begin{array}{l}\text { to clear or explain } \\
\text { (obj.) }\end{array}$ \\
\hline kros & to be angry & kros Im & to scold $(O b j)$. \\
\hline marit & to be married & maritim & to marry (Obj.) \\
\hline pas & to be stuck & pas Im & to fasten (obj.) \\
\hline pinis & $\begin{array}{l}\text { to be completed, } \\
\text { finished }\end{array}$ & pinisim & to finish (obj.) \\
\hline ran/ron & to run & ranlm & to chase (Obj.) \\
\hline sanap & $\begin{array}{l}\text { to stand up; to be } \\
\text { standing }\end{array}$ & sanap Im & $\begin{array}{l}\text { to stand up; erect } \\
(\text { obj.) }\end{array}$ \\
\hline s lek & to be slack, Zoose & slek Im & $\begin{array}{l}\text { to Zoosen, slacken } \\
\text { (obj.) }\end{array}$ \\
\hline s lip & $\begin{array}{l}\text { to sleep; to be } \\
\text { as leep or lying } \\
\text { down }\end{array}$ & slipim & to lay (obj.) down \\
\hline s Ingaut (long) & to call out (to) & s Ingaut Im & to call (obj.) \\
\hline gris $(\text { long })^{2}$ & $\begin{array}{l}\text { to (talk) in a } \\
\text { flattering way to }\end{array}$ & grls Im & to flatter (obj.) \\
\hline lukaut (long) & to care (for) & lukautim & to Zook after (Obj.) \\
\hline sut (long) & to shoot (at) & sut Im & to shoot $(O b j)$. \\
\hline smel (long) & to smezl (at) & smelim & to smelz (Obj.) \\
\hline wet (long) & to wait (for) & wet im & to await (obj.) \\
\hline wok (long) & to work (at) & wok Im & to buizd (Obj.) \\
\hline glaman $(\operatorname{long})^{2}$ & to tell lies (to) & glaman Im & to fool (obj.) \\
\hline $\begin{array}{l}\text { kIrap ( I ong) } \\
\text { skul ( l ong) }\end{array}$ & $\begin{array}{l}\text { to get up (from, on) } \\
\text { to learn (about) }\end{array}$ & $\begin{array}{l}\text { klraplm } \\
\text { skulim }\end{array}$ & $\begin{array}{l}\text { to begin, start (obj.) } \\
\text { to teach (obj.) }\end{array}$ \\
\hline
\end{tabular}

${ }^{I}$ Note that words ending in a add $r$ when they have the transitive verb marker -im suffixed to them, e.g., hama hammer becomes hamarlm to hammer (obj.), to beat up, knock. But for words like spla spear and klla clear ending in a sequence of vowels the a is "dropped". For example, spla becomes splrim to spear (Obj.) and klla becomes kllrim to clear (obj.).

2 These two verbs can also be said with tok as tok grls (long) and tok glaman (long) respectively. 


\section{Practice Drills}

Exercise 1: Answer the following questions using the cues provided:

1. Wanem samting i bagarap? Lek bilong $m i$ i bagarap.

2. Husat i hait? MALOLO i hait.

3. Tin i op? Yesa, tin i op.

4. Yu kros? Nogat, mi no kros.

5. Graun bilong husat i klia? (bilong dispela lain) (pause) Graun bilong dispela lain i klia.

6. Wanem samting i kapsait? (pasindia trak) (pause) Pasindia trak i kapsait.

7. Kap i bruk? Yesa, kap i bruk.

8. Wara I boil o nogat? Nogat, wara i no boil.

9. Wok bilong husat i pinis? Wok bilong mipela i plnis.

10. Husat i ran i go? Dogare i ran i go.

11. Rop i slek o nogat? Nogat, rop i no slek.

12. Husat $i$ skul long tok Inglis? Sampela tasol i skul long tok Inglis.

13. Yu wok we? Mi wok long Bipi.

14. Em i sut long wanem? Em i sut long dok bilong mi.

15. Husat i tok gris long dispela? (long dok bllong $\mathrm{mi}$ ) (pause) (long BIpl) (pause) ol Simbu i tok gris long dispela.

Exercise 2: Fretend you are in charge of a group of at least s1x employees. Tell them in Pldgin to do the following things as a group. Ready?

1. To open this box. 

2. To hide all their spears.
(Yupela haitim olgeta spia bilong,
yupela.)
3. To stand up this post.
(Yupela sanapim dispela pos.)
4. To loosen the rope.
(Yupela slekim rop.)
5. To teach you Pidgin.
6. To clear all the roads.
(Yupela skulim mi long tok Pisin.)
(Yupela klirim olgeta rot.)

Exercise 3: Now ask your group of employees whether they are going to do the following things or not. Begin your answers with bai. Ready? All right ask them

1. Are they going to chase the dog away or not?

(Bai yupela i ranim dok i go o nogat?)

2. Are they going to boil this milk or not?

(Bai yupela i boilim dispela susu o nogat?)

3. Are they going to call your father or not?

(Bai yupela i singautim papa bilong mi or nogat?)

4. Are they going to tip over the trucks or not?

(Bai yupela i kapsaitim ol trak o nogat?)

5. Are they going to finish their work or not?

(Bai yupela i pinisim wok bilong yupela o nogat?)

Exercise 4: In this exercise the instructor will give Pidgin sentences describing the state something is in. You have to reply with a sentence containing the appropriate corresponding transitive verb marked by -im. A subject will be supplied for you as a Pidgin cue. For example, if the instructor were to give the stative sentence wara $\mathrm{i}$ boil the water is boiling followed by the cue emtupela your answer should be emtupela i boilim wara those(2) are boiling the water. Ready?

1. Hanwas bilong mi i bagarap. (emtupela) (pause)

Emtupela i bagarapim hanwas bilong $\mathrm{mi}$.

2. Wara i boil. (mipela) (pause)

Mipela i boilim wara.

3. Plet i bruk. (dispela man) (pause)

Dispela man i brukim plet.

4. Graun i klia.

(ol) (pause)

01 i klirimgraun.

5. Bilum bilong mi i hait.

(husat) (pause)

Husat i haitim bilum bilong mi?

6. Dispela tin i op.

(mi) (pause)

Mi opim dispela tin. 


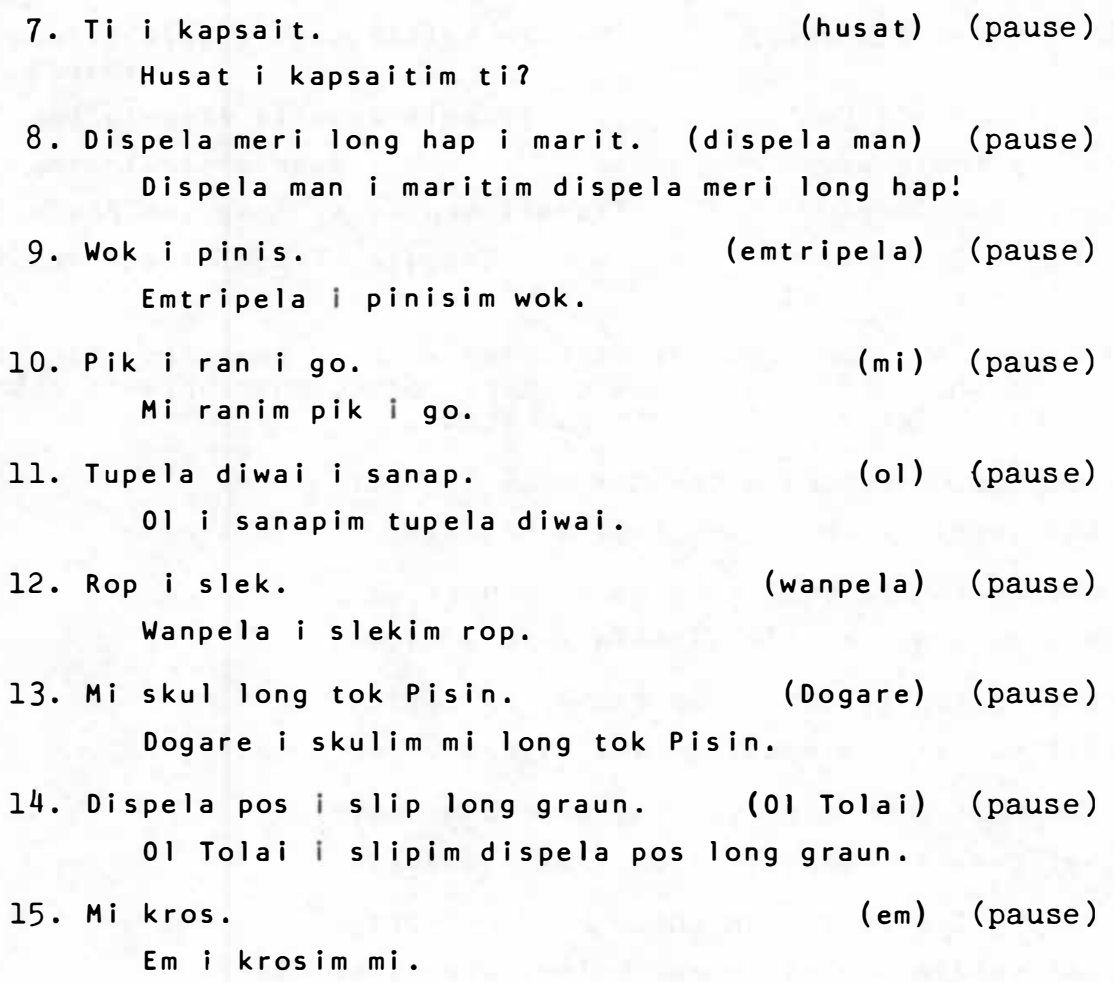

\section{4 REASON CLAUSES (because)}

The idea of because is expressed in Pidgin by bilong wanem. ${ }^{l}$ As you will note, this form is the same as that used for asking the question why in Pidgin. Note, however, that the clause introduced by bilong wanem because always follows the main clause.

Examples: $\begin{array}{ll}\text { Mi paitim dispela manki bilong } & \text { I hit this boy because he } \\ \text { wanem em i sakim tok bilong mi. } & \text { disobeyed me. }\end{array}$

01 i no go long gaden bilong They did not go to the garden wanem bikpela ren $i$ pundaun asde. because heavy rain fell yesterday.

In answer to questions, however, main clauses may be omitted, giving a short answer which, on paper, looks very much like another why question. In spoken Pidgin, however, there is no confusion because of the context and the intonational differences between the question and the answer. For example:
Q: Bilong wanem?
Why?
A: Bilong wanem mi sik.
Because I'm sick.

lor long wanem in some areas. 
Practice Drills

Exercise 1: Progressive Substitution

Frame: $\frac{\text { Mi no kisimpe bilong wanem mi lusim tingting longen. }}{\text { Mi no painim naip " }}$

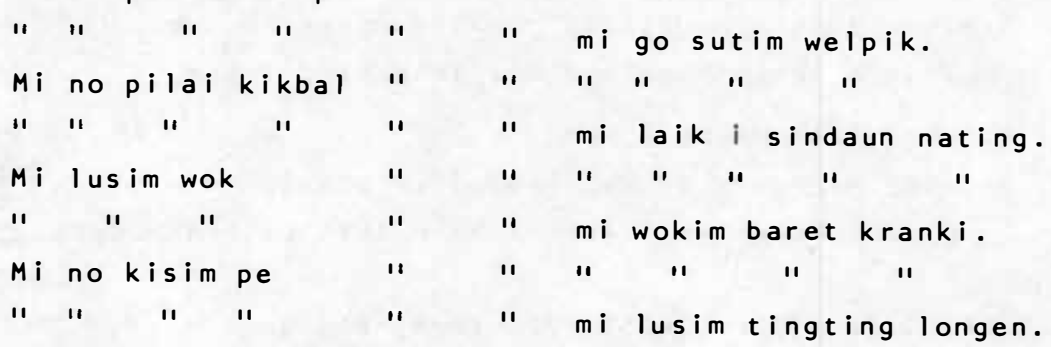

Exercise 2: Give full answers to the following questions using the cues provided:

1. Bilong wanem em $i$ no kam asde? (em i slip) (pause)

Asde em i no kam bilong wanem em i slip.

Em i no kam asde bilong wanem em i slip.

2. Bilong wanem yupela i sanap? (mipela i laik i

harim tok) (pause)

Mipela i sanap bilong wanem mipela i laik i harim tok.

3. Bilong wanem yu no laikimmi? (oltaim yu krosim

Mi no laikim yu bilong wanem oltaim yu krosim mi. (pause)

4. Bilong wanem kiap i stap long haus? (em i sik) (pause)

Kiap i stap long haus bilong wanem em i sik.

5. Bilong wanem ol i ranim pik bilong mi?

(em $i$ brukim banis bilong dispela gaden) (pause)

01 i ranim pik bilong yu bilong wanem em i brukim banis bilong dispela gaden.

\section{Evaluation Exercise}

Give short answers to the following questions using the English clues provided. That is, you omit the main clause which you would normally derive from the question. For example, if the question was Bilong wanem em $i$ no kam asde? and the cue was em $i$ slip your answer should be Bilong wanem em i slip. Ready?

1. Q: Bilong wanem em i go long taun?

A: Because she wanted to get some money from the bank.

$$
\text { Bilong wanem em i laik i kisim sampela mani long beng. }
$$

2. Q: Bilong wanem ol i singaut?

A: Because the pig is sick. It's probably about to die.

Bilong wanem pik i sik. Ating klostu em i dai pinis. 
3. Q: Bilong wanem yupela i sapim kanu olsem?

A: Because our forefathers used to do it like that.

Bilong wanem ol tumbuna bilong mipela i save mekim olsem.

4. Q: Bilong wanem emtupela i hait long bus?

A: Because they are waiting for the cargo to come.

Bilong wanem tupela $i$ wet long kago $i \mathrm{kam}$.

5. Q: Bilong wanem masta i kam?

A: Because he wants to buy crocodile skins.

Bilong wanem em i laik i baim skin bilong pukpuk.

\subsection{MORE ON RELATIVE CLAUSES (To Whom, Whoever)}

In Unit 6 you were introduced to Relative Clauses and were given some practise in forming and interpreting the least complicated type. In this section we shall consider those cases in which the noun common to the two sentences to be jolned occurs after long in one of those sentences. Take, for example, the sentences:

1a. Yu givim mani long pikinini

You gave the money to the child

1b. Pikinini i stap long hap

The child is over there

in which the word pikinini is common to both but occurs after long in la. Now, as already indicated in Unit 6 , either of these two sentences can be made into a relative clause and incorporated into the other (since they have pikinini in common). Thus one could have:

lc. Yu givim mani long pikinini em i stap long hap
Give the money to the child who is over there.

(in which the relative clause em i stap long hap is derived from sentence $1 \mathrm{~b})$, or one could have:

1d. Pikinini yu givimmani longen em i stap long hap

The child to whom you gave the money is over there

(in which yu givim mani longen is derived from sentence la.)

However, it is this last sentence that is of interest to us here. You will notice in it that pikinini has been replaced by en after long. The reason for this is that when sentence la became a relative clause pikinini became em just as you were taught in Unit 6 but then em became en according to the rule discussed in Section 3.1. So although the actual process of making the relative clause is the same as you have been taught before you have to remember to change em to en after long. This should be nearly automatic for you now but it is surprising how few learners can do it, or even remember to keep the long in the sentence they make.

Finally, it is convenient at this point to introduce you to two other forms connected with relative clauses in Pidgin. These are husat man/meri and wanem man/meri... whoever. These are very much the same except that one would not use the husat form for animals or other things which are not human. 
Examples:

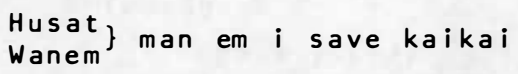

bulmakau em i olsem Yuropen.

Wanem
*Husat kokonas i pundaun,

em i bilong mi.

Practice Drills

\section{Exercise 1: Simple Substitution}

Frame: Dispela pikinini yu givimmani longen em i stap long hap. MALOLO i baim rot longen

ol manmeri i singaut longen

mipela i tok giaman longen

ol i soim buk longen

yu givim mani longen

Exercise 2: Simple Substitution

Frame: 01 dispela pikinini yu givim mani longen em ol i stap long hap.

$$
\begin{aligned}
& \text { MALOLO i baim rot longen } \\
& \text { manmeri i singaut longen } \\
& \text { mipela i tok giaman longen } \\
& \text { ol i soim buk longen } \\
& \text { yu givim mani longen }
\end{aligned}
$$

Exercise 3: Simple Substitution

Frame: Husat man em i save kaikai bulmakau em i olsem Yuropen.

Husat meri

Wanem pikinini

Wanem man

Husat man

Evaluation Exercise

Exercise 1: In this exercise you will hear pairs of sentences identified by numbers and the letters "a" and "b". Insert the second or "b" sentence into the first or "a" sentence as a relative clause.

1a. 01 dispela man i go we?

lb. Yu soim wilwil long ol dispela man.

(pause)

ol dispela man yu soim wilwil longol, em ol i go we? 
2a. Husat i lukim dispela hul.

2b. 01 rat i go insait long dispela hul.

(pause)

Husat i lukim dispela hul ol rat i go insait longen.

3a. Ating bai ol i kukim dispela longpela gras.

3b. 01 snek i save hait insait long dispela longpela gras.

(pause)

Ating bai ol i kukim dispela longpela gras ol snek i save hait insait longen.

4a. Dispela tokples i olsem tok lnglis.

4b. 01 i skulim mi long dispela tokples. (pause)

Dispela tokples ol i skulim mi longen, em i olsem tok Inglis.

5a. Yu go katim dispela diwai.

5b. 01 pikinini i save pundaun long dispela diwai. (pause)

Yu go katim dispela diwai ol pikinini i save pundaun longen.

Exercise 2: Say what the following sentences mean in English. Ready?

1. Wanem ka i kamap long ples pastaim em bai i ka bilong yumi?

(pause)

Whichever truck arrives at the vilzage first wizl be ours.

2. 01 dispela man yupela i givim gude longen em ol i bilong Indonesia.

(pause)

Those men you (pl.) said good-day to are Indonesians.

3. Husat pikinini i inap kaunim ol dispela mani em i ken go lukim Amerika.

Whichever child is able to count this money can go to see/visit America.

4. Yu no ken kukim ol dispela kiau em ol i gat yangpela kakaruk i stap insait longen.

(pause)

Don't cook these eggs with chickens in.

5. Mi no lukim gen dispela misis yumi i tok giaman longen.

(pause)

I didn't see that European woman again that we told lies to.

\section{TEXT}

Listen to the following text spoken by Wapi from Tumam village in the East Sepik District. Then check your textbook transcription and translate 1t. Here is the text:

Wokim ti olsem. Kukim hatwara pinis. Orait, sapos wara i boil yu putim liklik wara i go long tipot, hatim liklik, kapsaitim wara long tipot i go. Orait putim lipti go. Putim lipti go, orait, putim 
hatwara i go nau. Putim hatwara i go putim i stap. Bihain hatwara i kisim ti i go, i blak liklik, olsem sampela masta ol i laikim ti i blak, sampela masta ol i laikim ti i ret tasol. Orait, putim. Sapos ol i laikim suga putim suga, sapos ol i no laikim suga, kisim susu olsem suga ${ }^{2}$ i go putim long tebol. Bihain ol i yet putim. 0lsem husat i laikim susu putimsusu. Husat i no laikim susu, orait em i dringim ti nating. Em pasin bilong ti. 3

Em tasol.

\section{[Playing time: 1 minute]}

\section{ENGLISH TRANSLATION:}

(You) make tea like this. (You) put the water on to boil. Then suppose the water boils you put a little in the teapot and heat it up a little. Then tip out this hot water from the teapot and then put in the tea leaves. After that you pour in the hot water, and leave it ( lit. put in the hot water and put the pot to stay). Afterwards the hot water brings out the tea (lit. gets the tea)--it blackens a little. Some Europeans like (their) tea black, some like it only weak black (lit. red). All right put it (on the table). If they like sugar put sugar (on the table too); if they don't like sugar get milk and put it on the table instead (?) (lit. get milk as you would sugar). After that they can put (their own in). Thus whoever likes milk can put it in. Whoever doesn't can drink the tea without it. That's the way lof makingl tea. That's all.

Now to end this tape here is a recording by one of the recording volces of a poem, Nansei, which appeared in the Pangu Pati Nius, June $1972, p \cdot 3: 4$

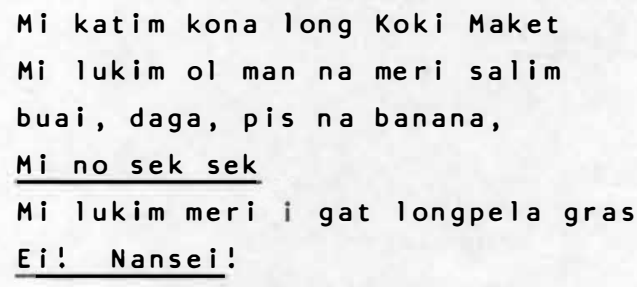

${ }^{1}$ Note the speaker's use of these adjectives without - pela.

2 I am not familiar with the structure susu olsem suga but from the context I take it to mean milk instead of sugar. This needs checking, however.

3 This text was recorded by Peter Mühlhäusler who informs me that this speaker's recipe for tea is as follows:

2 heaped tablespoons sugar

l tablespoon tea-leaves J Makes one cup!

Add a bit of boiling water. [continued overleaf] 
Wapi is aged about fortyfive and has spent a lot of time with Europeans in many parts of Papua New Guinea.

4 This poem was also published in Nansei, An Anthology of original Pidgin Poems, an edition of Papua Pocket Poets edited by Kumalau Tawali, Port Moresby: 1971.

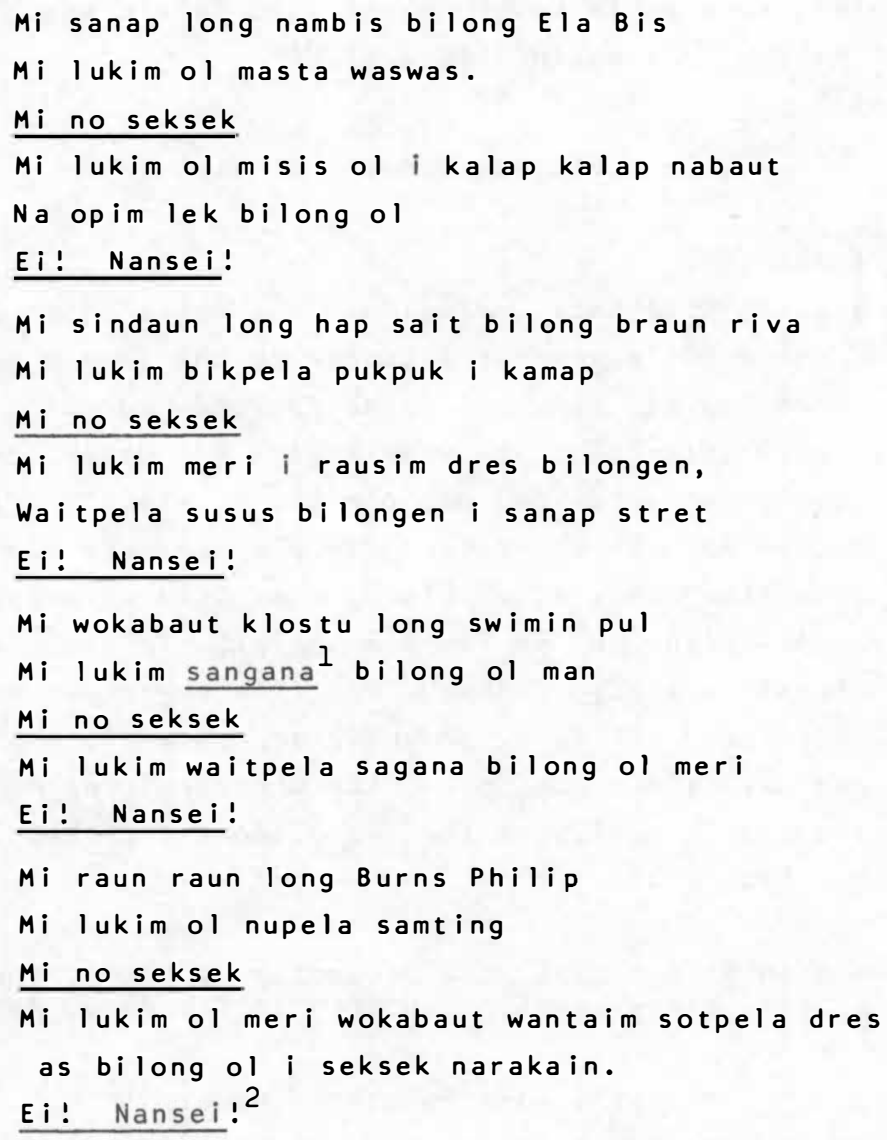

Tau Peruka

SUPPLEMENTARY VOCABULARY

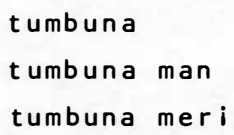




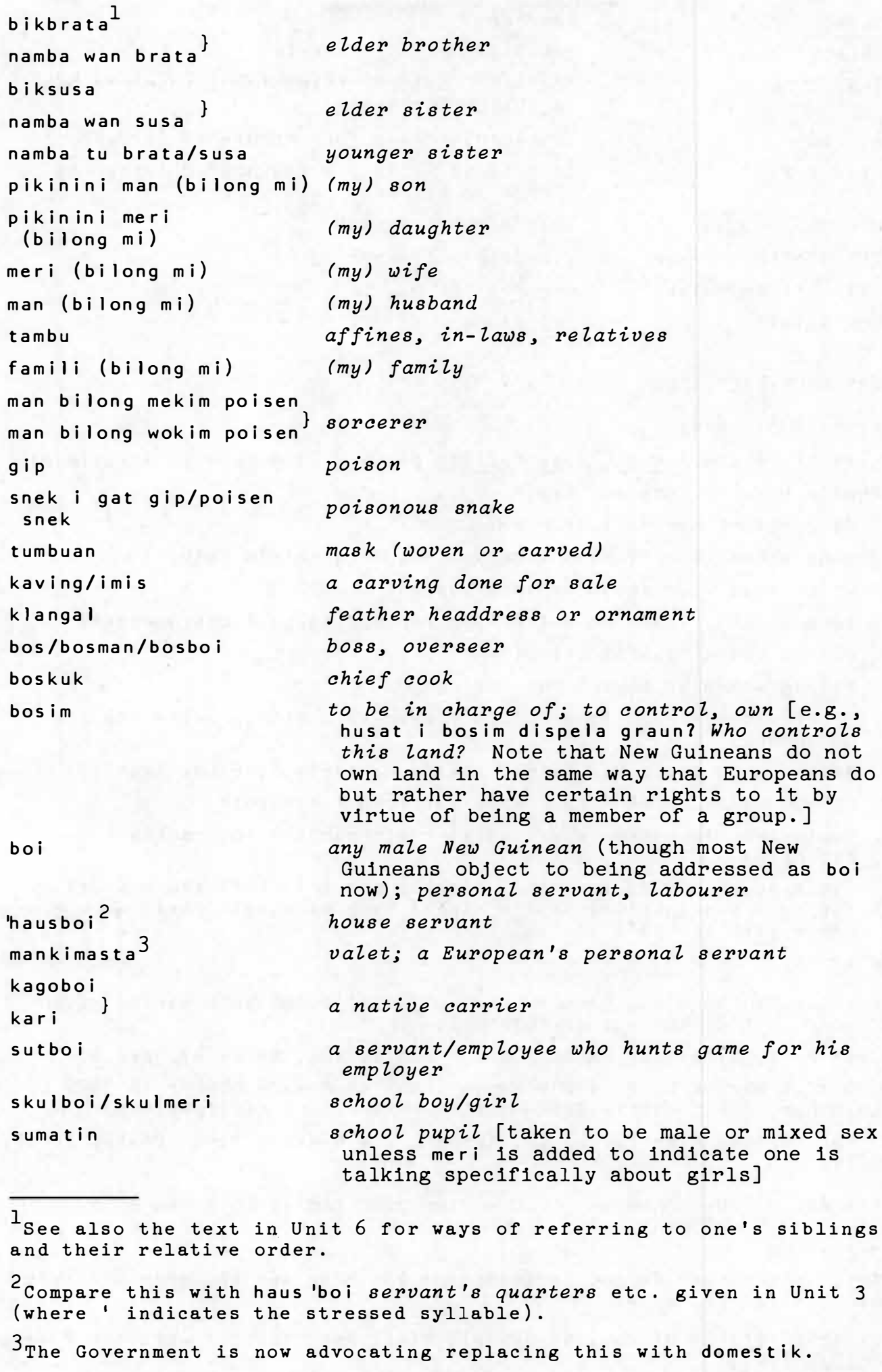

bo i

'hausboi ${ }^{2}$

mankimasta 3

kagoboi

kari

any male New Guinean (though most New Guineans object to being addressed as boi now); personal servant, labourer

house servant

valet; a European's personal servant

a native carrier

sutbo i

skulboi/skulmeri a servant/employee who hunts game for his
employer

sumatin

school boy/girl

school pupil [taken to be male or mixed sex unless meri is added to indicate one is talking specifically about girls]

\footnotetext{
and their relative order.

${ }^{2}$ Compare this with haus 'boi servant's quarters etc. given in Unit 3

(where' indicates the stressed syllable).

3 The Government is now advocating replacing this with domestik.
}

${ }^{1}$ See also the text in Unit 6 for ways of referring to one's siblings 


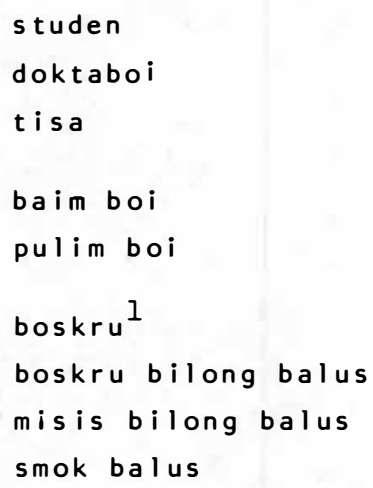

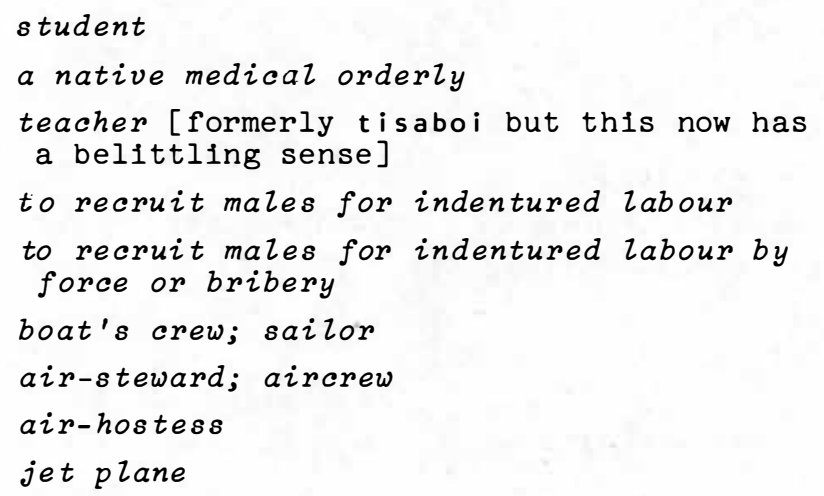

\section{CLASSROOM EXERCISES}

Exercise 1: Quiz

Yu ritim stori Rop bilong Spaida ${ }^{2}$ pastaim na bihain yu ansarim ol dispela kwestin long tok Pisin.

1. Mama bilong spaida i stap we?

2. Long wanem taim ol abus i hatwok tru long painim kaikai?

3. Wanem abus i go antap wantaim spaida?

4. Taim ol abus i bin go antap long rop spaida ol i mekim wanem?

5. Bilong wanem kapul i belgut?

6. Bilong wanem ol abus i bun nating?

7. Olsem wanem mama bilong spaida i save taimbilong pulim rop $i$ go antap?

8. Raitim song namba wan bilong spaida na tanim long tok Inglis.

9. Bilong wanem muruk i save wokabaut long lek tasol?

10. Wokim wanpela piksa long trausel i bin pundaun long baksait bilongen.

11. Tingting bilong yu $i$ wanem? Dispela stori i stori tru o stori nating o storibilong skulim mipela long stretpela pasin o wanem kain stori?

Em tasol.

Exercise 2: Read and compare the following poems with Nansei given at the end of this unit:

a. 01 Meri, Kirap! by Walter Darius (In Wantok, Namba 47, pes 8)

b. 0 Meri Wantok by Bede Dus Mapun (published as a poster in 1972 by the Centre for Creative Arts--series editor John Kasalpwalova)

c. Meri Bilong Ples Yet by Leo Kuabaal (In Nansei, Papua Pocket Poets, 1971).

Exercise 3: Describe your job and/or your family to someone in Pidgin.

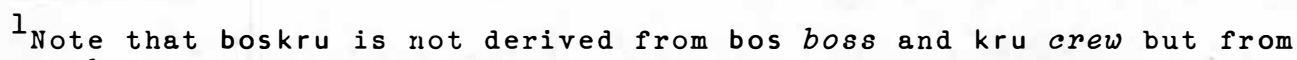
bos boat and kru crew.

2In Stori Bilong 01 Abus Na Sampela Stori Moa, Namba 2 (Kristen Press, Madang, 1969). 
Exercise 4: Language Game: 20 Quest1ons. Teacher or student thinks of some object and the remainder of the class attempts to find out what this is by asking questions. Answers to questions should be restricted to yes and no. [Use sparingly!]

Exercise 5: Compose interesting sentences by making suitable add1tions to the following:

1. 01 i no ken.... bilong wanem ....

11. Husat i inap....?

111. Bai mipela i salim....

1v. Nogut .... bilong wanem ....

v. Bilong wanem em i sanapim....?

vi. Wok bilong yumi .....

vi1. 01 Koiari ....

v111. 01 sem wanem yu brukim...?

1x. Emtupela i no save pilai susap bilong wanem ....

$x$. Nau yu ken i go na.... 


\section{UNIT 8}

\section{CONVERSATION}

\section{Long Kirapim Wok}

Dogare na narapela wokboil $i$ go

wantaim bosboi bilong wokim

baret. Bosboi i tok:

Bosboi: Yutupela i ken kirap wokim baret hia long dispela mak.

Dogare: Oke.

Bosbo1: Yu wanpela brukim graun long kroba pastaim na yu wanpela rausim dispela graun bruk long spet. Yutupela wokim olsem. Save?

Dogare: Mitupela i save.

Bosbo1: Orait. Maski hambak!

Sapos yutupela $i$ wok strong (orait) bai yutupela i kisim bikpela pe. 2

Dogare: I orait. Mitupela i wokim traim pastaim. 3 Na tupela wanwok ${ }^{4}$ i kirap wokim baret bilong putim simen.
Dogare and another worker went with the overseer to dig the trench. The overseer said: You two can begin to dig this trench here at this mark.

ok.

You alone dig up the ground with the crowbar and you alone shovel the broken up ground. Do it like that. Understand?

Yes.

ok. No fooling about! If you two work well you'll get big pay.

All right. We'll try it first.

And the two (fellow) workers began to dig the trench for cement.

\section{[Musik ${ }^{5}$ ]}

\footnotetext{
${ }^{1}$ Note the difference between wokboi a worker (i.e. one who is employed to work--see footnote 2 to the Conversation in Unit 7 ) and man/boi bilong wok a worker (i.e., one who is always working--see section 4.4 above).

${ }^{2}$ As will be seen later in section 8.3 orait is optional in sentences like these. It does not appear in the recorded version but does in the practice versions.

3 Traim will be drilled in Section 13.3 below.
} 
4

4 Note wanwok fellow worker here and compare it with wantok already learnt. Pidgin has many similar forms based on wan which often have no neat English equivalent expression, e.g.,

wanhaus a person living in the same house, house mate, flat mate wanlain a person of the same (age, social) group

wanpes a person of the same appearance

More of these are presented in the Vocabulary Expansion Exercises given below.

5 Two traditional songs are heard on this tape. The first is

Yongi-na-nei from the Finschafen Area near Lae and is a solo performance of singing and drumming from the Gia-oni head-dress dance.

[Sheridan (1958: side l, track l, item b)].

The other is Abe. In this a Kukukuku bowman strums the string of his great fighting bow; after this he sings a very primitive song. It is a chant of the hunt and the feast to follow. The Kukukuku carry their bows everywhere with them. They twang the string excitedly as they relate the saga of a battle. They strum it almost absentmindedly when getting ready for their simple dance. [Sheridan (1958: side 1, track 6, item c).]

\title{
USEFUL EXPRESSIONS
}

Bilong wanem yu mekim olsem?

Bilong wanem em laik bilong $\mathrm{mi}$.

Bilong wanem em pasin bilong mi.'

o sori, em kas bilong yu.

Tru, mi laki tru.

\section{VOCABULARY EXPANSION EXERCISES}

\section{Exercise 1: Simple Substitution}

Frame: Maski hambak!

kilim i dai pik
lukluk nating
rausim banis
nildaun
ranawe
kliraut
hambak

Why are you doing it like that?

Because that's the way I want to do it; that's my wish/manner.

'That's your good luck.

Yes, I'm very Zucky.

(kill the pig)
(stare)
(pulz down the fence)
(kneel down)
(run away)
(go away)

Exercise 2: Simple Substitution

Frame: Sapos yutupela i wok bikpela pe.

\author{
gut (we ZZ) \\ hariap (quickly, hurriedly) \\ isi isi (carefulzy) \\ arawe (differently) \\ [continued overleaf]
}




\begin{tabular}{|c|c|c|}
\hline $\begin{array}{l}\text { apos yutupela i wok } \\
\text { ikpela pe. }\end{array}$ & arawe, & ait bai \\
\hline & $\begin{array}{l}\text { wantaim } \\
\text { ol sem } \\
\text { nabaut } \\
\text { strong }\end{array}$ & $\begin{array}{l}\text { (together) } \\
\text { (thus) } \\
\text { (around) }\end{array}$ \\
\hline
\end{tabular}

Exercise 3: Simple Substitution

Frame: Mitupela i wokim traim pastaim.

\begin{tabular}{ll}
\hline hatim & $($ to heat (obj.) up) \\
holim & (to hold (obj.)) \\
klinim & (to clean (obj.)) \\
krungutim & (to bend (obj.)) \\
tanim & (to turn (obj.)) \\
skelim & (to weigh, share out (obj.)) \\
raunim & (to surround, chase (obj.)) \\
swimim & (to float (obj.)) \\
hangamapim & (to hang (obj.) up) \\
wokim &
\end{tabular}

Exercise 4: Simple Substitution

Frame: Na tupela wanwok i kirap wokim baret.

\begin{tabular}{|c|c|}
\hline wanbel & $(t w i n)$ \\
\hline wannem & (namesake) \\
\hline wanblut & (blood relative) \\
\hline wanhaus & $\begin{array}{l}\text { (a person living in the } \\
\text { house) }\end{array}$ \\
\hline wanpila i & (playmate) \\
\hline wanrot & (travelzing companion) \\
\hline wansospen & (messmate) \\
\hline wanples & $\begin{array}{l}\text { (persons from the same } \\
\text { vilzage) }\end{array}$ \\
\hline
\end{tabular}

\section{GRAMMAR}

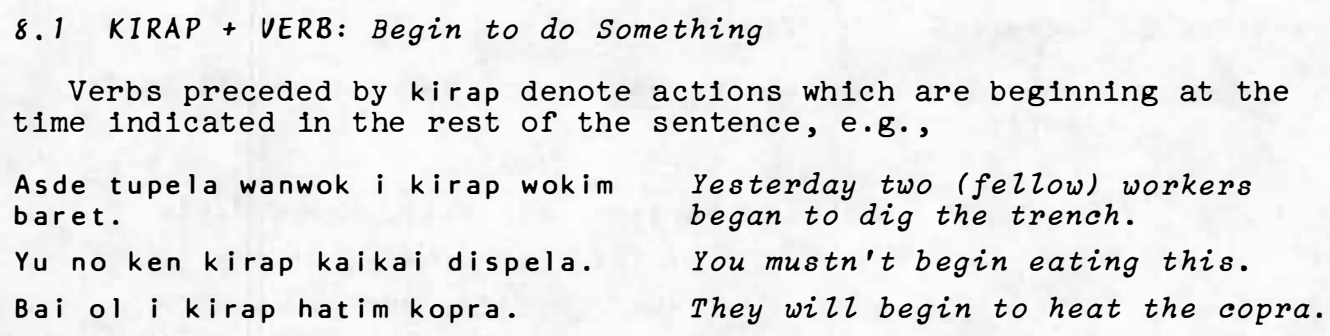


Practice Drills

Exercise 1: Simple Substitution

Frame: Bai ol i kirap hatim kopra.

(skelim rais, raunim welpik, klinim gaden, kukim rais, hangamapim ol bilum, hatim kopra)

Exercise 2: Ask the following questions in Pidgin.

1. When will they begin to build the store?

(pause)

Long wanem taim bai ol i kirap wokim stua?

2. Who is beginning to eat?

(pause)

Husat i kirap kaikai?

3. Are all of you beginning to heat the copra or not? (pause)

Yupela olgeta i kirap hatim kopra o nogat?

4. Why is he beginning to share out the rice?

(pause)

Bilong wanem em i kirap skelim rais?

5. Which car is beginning to break down?

(pause)

Wanem ka i kirap bagarap?

\subsection{EMPHATIC PRONOUNS: Yet, Tasol, Wanpela}

In Pidgin there are several ways of emphasizing the fact that you (or someone else) performed an action on your (or his) own, or were the object of some action.

One is by placing yet after the pronoun representing the person or persons involved, e.g.,

Mi yet i brukim graun.

01 i paitim mi yet.

$\left\{\begin{array}{l}\text { I myself dug the ground. } \\ \text { I dug the ground myself. }\end{array}\right.$

They hit me. (I didn't hit them.)

Another is by placing tasol only after the pronoun representing the person or persons involved, e.g.,

Mi tasol i brukim graun.

01 i patim mi tasol.

A third is by placing wanpela alone after the pronouns $m i$, yu, and em representing the person involved, e.g.,

Mi wanpela i brukim graun.

01 i paitim mi wanpela.
Only I (no one else) dug the ground.

They hit only me.

Note that in this last case there is no possible form $\mathrm{mipe}$ la wanpela for we alone etc. One would have to express this by using either yet or tasol given above. 
Thus the set of pronouns presented so far can now be expanded to include the following:

\begin{tabular}{|c|c|c|c|c|c|}
\hline Pidgin & English & Pidgin & English & Pidgin & English \\
\hline mi yet & $\begin{array}{l}I \text { myself } \\
\text { Me myself }\end{array}$ & mi tasol & $\begin{array}{l}\text { Only I } \\
\text { Only me }\end{array}$ & mi wanpela & $\begin{array}{l}\text { I alone } \\
\text { Me alone }\end{array}$ \\
\hline yu yet & You yourself & yu tasol & only you & yu wanpela & You alone \\
\hline em yet & $\begin{array}{l}\text { He himself } \\
\text { She herself } \\
\text { It itself }\end{array}$ & em tasol & $\begin{array}{l}\text { Only he } \\
\text { only she } \\
\text { only it }\end{array}$ & em wanpela & $\begin{array}{l}\text { He alone } \\
\text { She alone } \\
\text { It alone }\end{array}$ \\
\hline $\begin{array}{l}\text { mipela yet } \\
\text { yumi yet }\end{array}$ & $\begin{array}{l}\text { We ourselves } \\
\text { We ourselves }\end{array}$ & $\begin{array}{l}\text { mipela tasol } \\
\text { yumi tasol }\end{array}$ & $\begin{array}{l}\text { only we } \\
\text { only we }\end{array}$ & & \\
\hline
\end{tabular}

Finally, notice that all of these emphatic forms are followed by the predicative marker $i$ when they occur in the subject, 1 except for commands when the pronoun is repeated, e.g., compare

$$
\begin{array}{ll}
\text { Yu yet i kaikai pik. } & \text { you are eating pork. } \\
\text { Yu yet yu kaikai pik! } & \underline{\text { you eat pork! }}
\end{array}
$$

Practice Drills

Exercise 1: Simple Substitution

Frame: Mi wanpela i spak long pati.

(yu wanpela, mipela tasol, em yet, yumi tasol, mi wanpela)

Exercise 2: Progressive Substitution

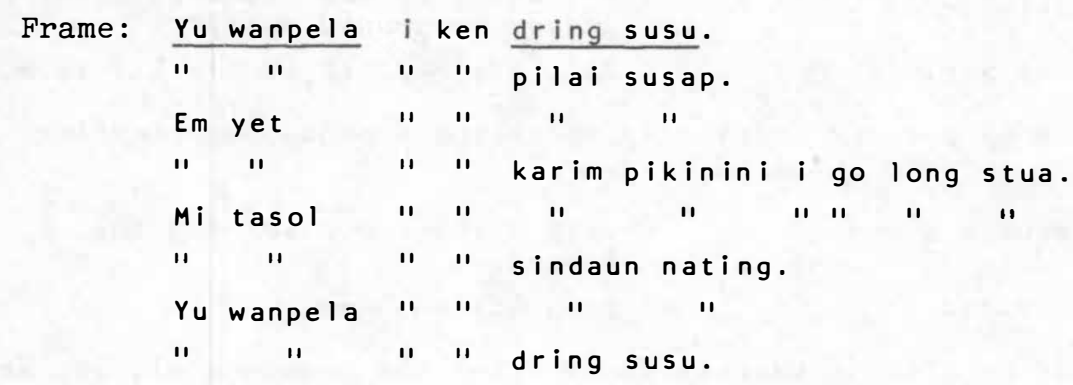

\section{Evaluation Exercises}

Exercise 1: Repeat the following sentences substituting the appropriate wanpela form of the pronoun for those used. Ready?

1. Em olgeta i laik i slip.

(pause)

Em wanpela i laik i slip.

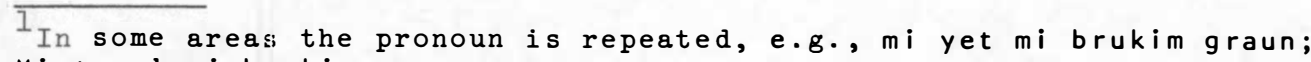

Mi tasol mi brukim graun. 
2. Masta i giamanim mipela.

(pause)

Masta i giamanim mi wanpela.

3. Husat i lukim yu?

(pause)

Husat i lukim yu wanpela?

4. Bai mitripela i helpim ol Simbu.

(pause)

Bai mi wanpela i helpim ol Simbu.

5. Em olgeta i no lainim tok Pisin.

(pause)

Em wanpela i no lainim tok Pisin.

Exercise 2: How would you say the following things in Pidgin? Ready?

1. That's your good luck and yours alone.

(pause)

Em kas bilong yu wanpela.

2. Only the two playmates weighed out the pork thus.

(pause)

Tupela wanpilai tasol i skelim pik olsem.

3. They will begin to heat the copra themselves. (pause)

Bai ol yet i kirap hatim kopra.

01 yet bai ol i kirap hatim kopra.

4. He alone is dressing up for no reason.

(pause)

Em wanpela i bilas nating.

5. Only children are allowed to drink milk.

(pause)

\{ Pikinini tasol i ken dring susu.

ol pikinini tasol i ken dring susu.

6. I did it myself.

(pause)

Mi yet i mekim.

\subsection{CONDITIONAL CLAUSES (Sapos)}

Clauses introduced by sapos if, suppose in Pidgin are Conditional Clauses. They generally come first in a sentence and are usually connected to what follows by orait.

Examples:

Sapos yutupela i wok strong, orait bai yutupela i kisim

bikpela pe.

Sapos trak i kapsait, orait bai ol pasindia i mekim wanem?

Sapos yu kam long moningtaim, orait mi inap givimpe long yu.
If you(2) work well you(2)' $2 z$ get paid wezz.

Suppose the truck tips over what will the passengers do?

If the truck tips over what wizl happen to the passengers?

If you come in the morning I' $I Z$

be able to pay you. 
Sapos yu no kam long moningtaim orait ating mi no inap givim pe long yu.
If you don't come in the morning I'll probably not be able to pay you.

Unless you come in the morning I'll probably not be able to pay you.

Note that adverbs of time come at the end of clauses in these sen-

tences. See, for example, the last three examples given above.

Practice Drills

Exercise 1: Simple Substitution

Frame: Sapos em i kam, orait bai mi sutim em.

(yu, tupela, ol, yupela, em tupela, em)

\section{Exercise 2: Simple Substitution}

Frame: Sapos mi no sik, orait mi wok.

(les, kus, kol, pulap, sotwin, sik)

Exercise 3: In the following exercise the instructor will give two sentences identified as (a) and (b). You have to join these together using sapos and orait. For example, if the instructor were to say:

10a. Em i slip.

10b. Em i no ken kaikai.

your answer should be Sapos em i slip, orait em i no ken kaikai. If he sleeps then he's not allowed to eat. Ready?

la. Kiap i no harim tok bilong mipela.

b. Bai mipela i paitim het bilongen.

Sapos kiap i no harim tok bilong mipela, orait bai mipela i paitim het bilongen.

If the Government official doesn't listen to us then we'll box his ears.

2a. Balus i no kam.

b. Bai yumi i no inap kaikai.

Sapos balus i no kam, orait bai yumi i no inap kaikai.

Unless the plane comes we'll not be able to eat.

3a. Trak i kapsait.

b. Bai ol pasindia i mekim wanem?

Sapos trak i kapsait, orait bai ol pasindia i mekim wanem? Suppose the truck tips over what will happen to the passengers? 
4a. Yupela bihainim dispela hanrot.

b. Bai yupela i kamap long stesin.

Sapos yupela i bihainim dispela hanrot, orait bai yupela i kamap long stesin.

If you folzow this sidetrack then you'll arrive at the station.

5a. 01 i no helpim yu.

b. Bai yu no helpim ol.

Sapos ol i no helpim yu, orait bai yu no helpim ol.

If they don't help you then you won't help them.

6a. Hanwas i dai.

b. Bai yumi i save taim olsem wanem?

Sapos hanwas i dai, orait bai yumi i save taim olsem wanem?

If the watch stops how will we know the time?

7a. 01 Yuropen i giaman.

b. Bai ol i bagarapim wok bilong mipela.

Sapos ol Yuropen i giaman, orait bai ol i bagarapim wok bilong mipela.

If the Europeans lie then they'll ruin our work.

Exercise 4: Now repeat the same Pidgin sentences (from Exercise 3 above) leaving out the connective orait. In spoken Pidgin this is an optional choice which does not affect the meaning of the sentences. Ready?

1. Sapos kiap i no harim tok bilong mipela, orait bai mipela i paitim het bilongen.

(pause)

2. Sapos balus i no kam, orait bai yumi i no inap kaikai. (pause)

3. Sapos trak i kapsait, orait bai ol pasindia i mekim wanem?

(pause)

4. Sapos yupela i bihainim dispela hanrot, orait bai yupela i kamap long stesin.

(pause)

5. Sapos ol i no helpim yu, orait bai yu no helpim ol.

Exercise 5: This exercise is similar to the previous one except that you have to shift the time words like Mande, tumara etc. to the ends of their clauses. Ready?

1a. Long Mande suga i pinis.

b. 01 wokboi i ken kisim nupela.

Sapos suga i pinis long Mande, orait bai ol wokboi i ken kisim nupela.

If the sugar runs out on Monday then the Zabourers can get some more. 
2a. Tumora yu kam.

b. Bai yu kam wantaim kandere bilong yu.

Sapos yu kam tumora, orait bai yu kam wantaim kandere bilong yu.

If you come tomorrow then come with your maternal uncle.

3a. Hapasde em i no bin lusim tudola.

b. Em i inap baim narapela gita nau.

Sapos em i no bin lusim tudola hapasde, orait em i inap baim narapela gita nau.

If he hadn't lost two dollars the day before yesterday, then he'd be able to buy another guitar now.

4a. Yupela ol Papua Niu Gini i bin save tok Inglis bipo.

b. Yupela i inap wok bisnis nau.

Sapos yupela ol Papua Niu Gini i bin save tok Inglis bipo orait yupela i inap wok bisnis nau.

If you Papuan and New Guineans had known English before you would now be able to enter business.

5a. Asde yu no bin kam.

b. Tude yumi i no hangre.

Sapos yu no bin kam asde, orait yumi i no hangre tude.

If you hadn't come yesterday we'd not be hungry today.

\section{Evaluation Exercise}

How would you say the following things in Pidgin? Ready?

1. If you are happy I'm happy too.

(pause)

Sapos yu hepi, orait mi hepi tu.

2. Suppose your father plants coffee will you help him or not?

(pause)

Sapos papabilong yu i planim kopi, orait bai yu helpim em o nogat?

3. If the Tolai had not fought then today they would not have any land.

(pause)

Sapos ol Tolai i no bin pait, orait ol i no gat graun tude/nau.

4. If these women don't care for their children then the children will die.

(pause)

Sapos ol dispela meri i no lukautim pikinini bilong ol, orait bai ol pikinini i dai.l

5. Suppose you (pl.) get work tomorrow then let us buy a truck.

Sapos yupela i kisim wok tumora, orait yumi baim wanpela
trak.

\footnotetext{
${ }^{l}$ Remember that if one wants to make sure one means die and not merely
} become unconscious then one would say ol pikinini i dai pinis. This 


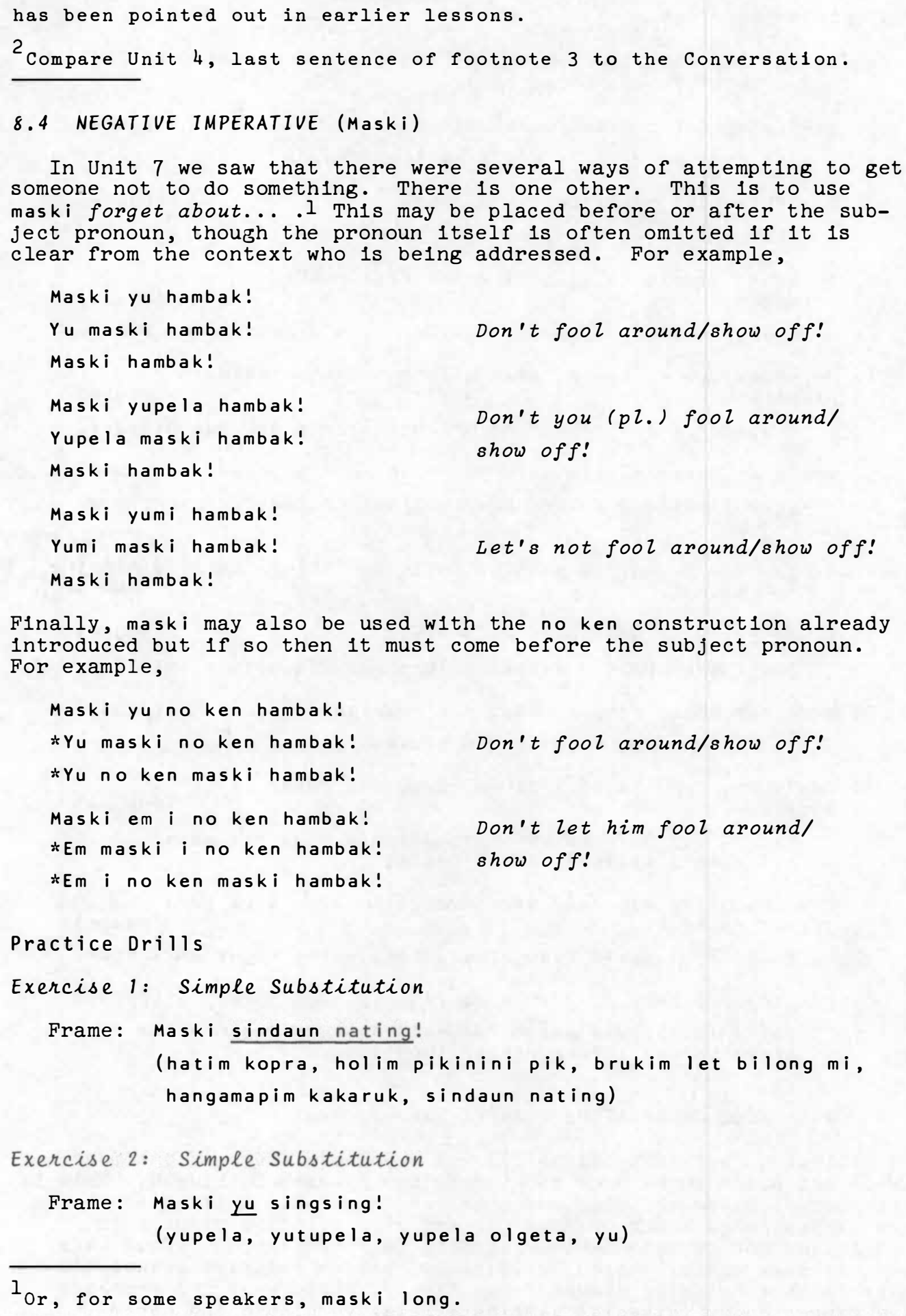

In Unit 7 we saw that there were several ways of attempting to get someone not to do something. There is one other. This is to use maski forget about... . I This may be placed before or after the subject pronoun, though the pronoun 1tself is often omitted if it is clear from the context who is being addressed. For example,

Maski yu hambak!

Yu maski hambak!

Don't fool around/show off'!

Maski hambak!

Maski yupela hambak!

Yupela maski hambak!

Maski hambak!

Don't you (pl.) fool around)

Maski yumi hambak!

Yumi maski hambak!

show of $f$ !

Maski hambak!

Finally, maski may also be used with the no ken construction already Introduced but if so then 1t must come before the subject pronoun. For example,

Maski yu no ken hambak!

$\star Y u$ maski no ken hambak!

Don't fool around/show off'

*Yu no ken maski hambak!

Maski em i no ken hambak!

*Em maski i no ken hambak!

*Em i no ken maski hambak!

Don't let him fool around/

show off!

Practice Drills

Exercise 1: Simple Substitution

Frame: Maski sindaun nating!

(hatim kopra, holim pikinini pik, brukim let bilong mi, hangamapim kakaruk, sindaun nating) 


\section{Evaluation Exercises}

Exercise 1: Say what the following Pidgin sentences mean in English. Ready?

1. Yupela sindaun; maski wokabaut!

Sit down you (pl.), don't walk around.

2. Yu ritim buk; maski toktok oltaim.

(pause)

Read the book, don't be talking all the time!

3. Yutupela klinim ka isi isi; maski rausim skin bilongen.

Clean the car carefully you(2). Don't remove the paint.

4. He, maski yu kaikai dispela pis em i gat wanpela bikpela sik.

(pause)

Hey, don't eat this fish which has some serious disease.

5. Wokim em olsem mi bin soim yu; maski wokim arawe. (pause)

Make it like I showed you, not some other different way.

Exercise 2: How would you say the following things in Pidgin using maski?

1. Don't hit your namesake; help him!

(pause)

Maski (yu) paitim wannem bilong yu. Yu helpim em!

2. Cook the rice, forget about the sweetpotato.

(pause)

Yu kukim rais, maski kukim kaukau.

3. Don't buy food in this store here, the owner is a thief.

(pause)

Maski (yu) baim kaikai long dispela stua hia papa

bilongen i stilman/man bilong stil.

4. Don't put the egg near the fire; it wouldn't be good for it to break.

(pause)

Maski (yu) putim kiau klostu long paia; nogut em i bruk.

5. Don't greet her; if you do she'll run away home. (pause)

Maski (yu) givimgutde longen; sapos yu mekim olsem

orait bai em i ranawe $i$ go long haus.

\subsection{STILL MORE ON RELATIVE CLAUSES (Where, What)}

Following on from Sections 6.2 and 7.5 above there is one more important point to be made about relative clauses in Pidgin. This is that where, wherever, what and whatever in certain English sentences are expressed by nouns or noun phrases plus relative clauses in Pidgin and not by we and wanem as most learners expect. Thus where and wherever are expressed by (dispela) ples + relative clause and wanem ples + relative clause respectively, while what and whatever are expressed by (dispela) samting + relative clause and wanem samting + relative clause respectively. That is, Pidgin approximates 
to the literal forms of in the place in which... for where, in which place in which... for wherever; this thing that... for what and which thing that... for whatever in English. The following examples illustrate the relevant kinds of sentences.

where/wherever.

Yu putim kago long dispela ples diwai i sanap longen.

Put the goods where the tree is standing lit. in the place in which the tree is standing).

01 i wokim bare: long dispela ples mi skulim ol longen.

They dug the trench where I

Mi save dispela ples yu go longen.

Mi inap painim yu long wanem ples yu hait longen. taught them to.

I know where you are going.

I can look for you wherever you hide.

What/Whatever

Mi save dispela samting yu laik

I know what you want to get

i kisim em.

(lit. that which you want...).

01 i rausim ol dispela samting

masta $i$ no inap kukim em.

They threw out what the

European could not cook.

Bai emtupela i lusim wanem

samting yu wokim em longen.

Those two will lose whatever you make for them.

Practice Drills

Exercise 1: Simple Substitution

Frame: Yu putim kago long ples dimai i sanap longen.

ol i no inap stilim em longen

stuakipa i ken kisim em longen

bai masta i lukim em longen

ol manki i no kam bagarapim em longen

Exercise 2: Simple Substitution

Frame: Mi save dispela samting yu laik i kisim em.

01 i lukim

Em i no kukim

Misis i lusim

Dok i kaikai

Mi save

\section{Exercise 3: Simple Substitution}

Frame: God i save wanem samting yu mekim em. 


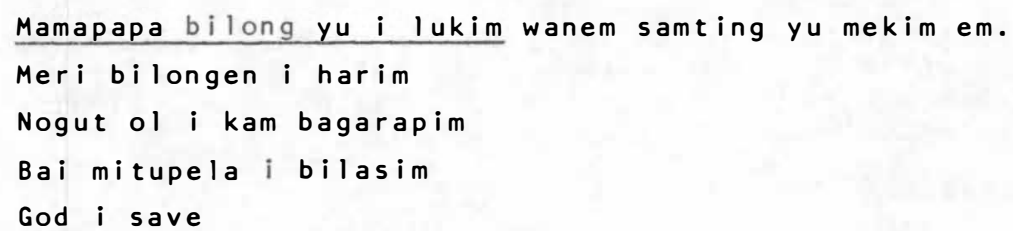

\section{Evaluation Exercise}

Sketch a picture of two boys standing near a pig with a man in the distance on a plece of scrap paper and answer the following questions about the picture in Pidgin in complete sentences using the cues provided.

1. Q: Yu inap lukim dispela ples pik i stap longen?

(yes)

A: Yes, mi inap lukim dispela ples pik i stap longen.

2. Q: Orait, pik i stap we? (near where the two boys are standing) A: Pik i stap klostu long ples tupela manki i sanap longen.

3. 6!: Tasol, yu inap lukim dispela samting pik i mekim em? (no)

A: Nogat, mi no inap lukim dispela samting pik i mekim em.

4. Q: Husat i inap lukim?

A: God i inap lukim.

5. Q: Yu ting wanem? God em i inap lukim wanem samting yumi i mekim em? (I don't know; perhaps)

A: Mi no save. Ating God em i inap lukim wanem samting yumi i mekim em.

6. Q: Yu save dispela samting man i tokim em long dispela tupela manki.

A: Nogat, mi no save dispela samting man i tokim em long dispela tupela manki.

\section{TEXT}

Listen to the following description of what a particular kind of spear is used for and then see if you can transcribe and translate 1 t. The description is given by Adam, from Chambri Village in the Chambri Lakes area, who is aged about thirtyfive and who is a wood carver in Kreen near Wewak. Here is the story:

Am, wok bilong dispela spia mi ken tokim yu stu (?). Dispela spia tam $^{1}$ (?) ol papa tumbuna bipo ol i stap long birua taim ol i pait. Nau ol i karim dispela spia. I gat tripela spia. Namba wan spia, holim, troimwe i go long birua, ol i kilim man. Namba tu ol i troimwe i go. Namba tri dispela spia, ol i no troimwe. 01 holim $^{2}$

${ }^{1}$ This may be taim or the vernacular name of the spear being discussed. ${ }^{2}$ Note that holim is pronounced wolim by this speaker. 
strong olgeta. Sapos birua i kamap long pait wantaim ol narapela lain birua em bai ol i pait long dispela spia. Sapos ol i troimwe dispela spia, nogat, ol i no inap long winim ol baimbai ol narapela lain birua i kam ol i kilimol i dai pinis. Orait em dispela spia ol i no troimwe ol i holim strong olgeta. Inap ol i pait gokilim man olrait tit bilongen ol i sutim man. Pulim i kam bek dispela tit bilong spia i bruk insait long bodi bilong man. Orait mani dai. Em. Stori bilong dispela spia.

Orait, tenkyu tru.

Tenkyu Pita.

\title{
[Playing time: 1.5 minutes]
}

ENGLISH TRANSLATION:

Um, I can tell you what this (kind of) spear was used for. This spear, called tam (?), was used in the time of our ancestors when there was fighting. Then they carried this spear (around). There are three spears. The first one was for holding and throwing at the enemy and wounding them. The second one was for throwing but the third one, this one, was not for throwing. One held on to it very firmly. If an enemy arrived to fight with other groups they would fight with this spear. If they threw this spear they would not be able to overcome them (the others) (because) another group of fighters (could) come and kizl them. So they did not throw these spears, they held on to them very firmly, until such times as they fought and they (the spears) would wound a man and then its point would pierce that person and when it was withdrawn this point would break inside that person's body, and he would then die. That's the description of this spear. All right, thank you very much.

Thank you Peter.

Now to end this unit here is a Pidgin song composed and sung by Mr. Mike Goodman, a European Agricultural Officer, in Papua New Guinea.

\author{
Mipela Didiman \\ Mipela mipela didiman \\ Husat meri laik i ken \\ 01 i kolim mipela nambawan man \\ o mipela didiman
}




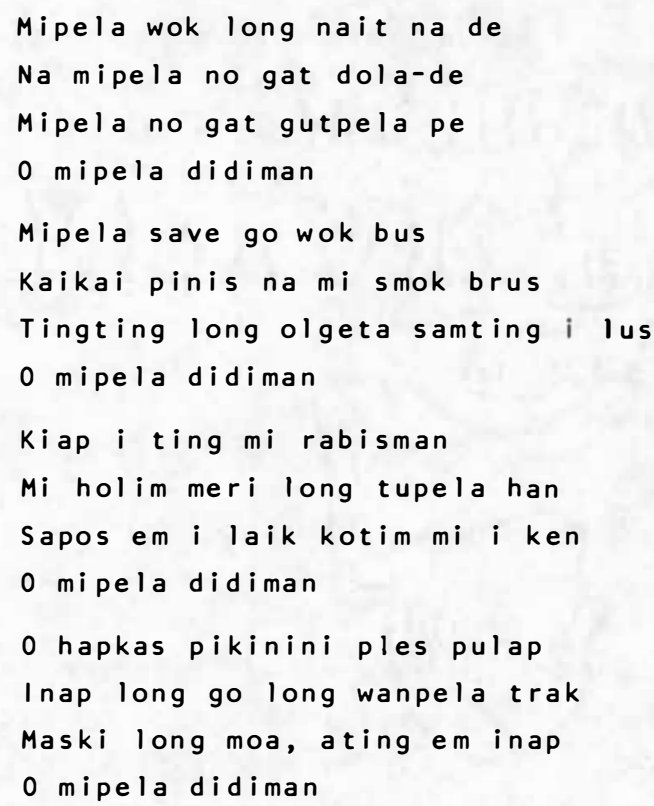

SUPPLEMENTARY VOCABULARY

\begin{tabular}{|c|c|c|}
\hline \multicolumn{2}{|l|}{ kol ta } & bitumen, creosote \\
\hline \multicolumn{2}{|l|}{ akis } & $a x e$ \\
\hline \multicolumn{2}{|l|}{ tam iok } & tomahawk \\
\hline \multicolumn{2}{|c|}{ wilka/supka/wilbero } & whe elbarrow \\
\hline subim wilka i & go/kam & \\
\hline pulim wilka i & $\mathrm{go/kam}{ }^{\}}$ & to wheel a barrow away/towards \\
\hline diwai & & $\log$ \\
\hline sen & & chain \\
\hline b lok & & puzley \\
\hline waia & & wire; also tea strainer \\
\hline blokim & & to raise with a block and tackle \\
\hline waia bras & & copper wire \\
\hline waia a in & & steel wire \\
\hline ki wara/kok & & tap \\
\hline kapa & & sheet metal, galvanized iron \\
\hline hat a in & & steel helmet \\
\hline hat plastik & & plastic helmet \\
\hline a i n & & iron, metal, steel \\
\hline pika & & pick \\
\hline mambu & & pipe \\
\hline spana & & spanner, wrench \\
\hline pukpuk spana & & pipe wrench \\
\hline
\end{tabular}




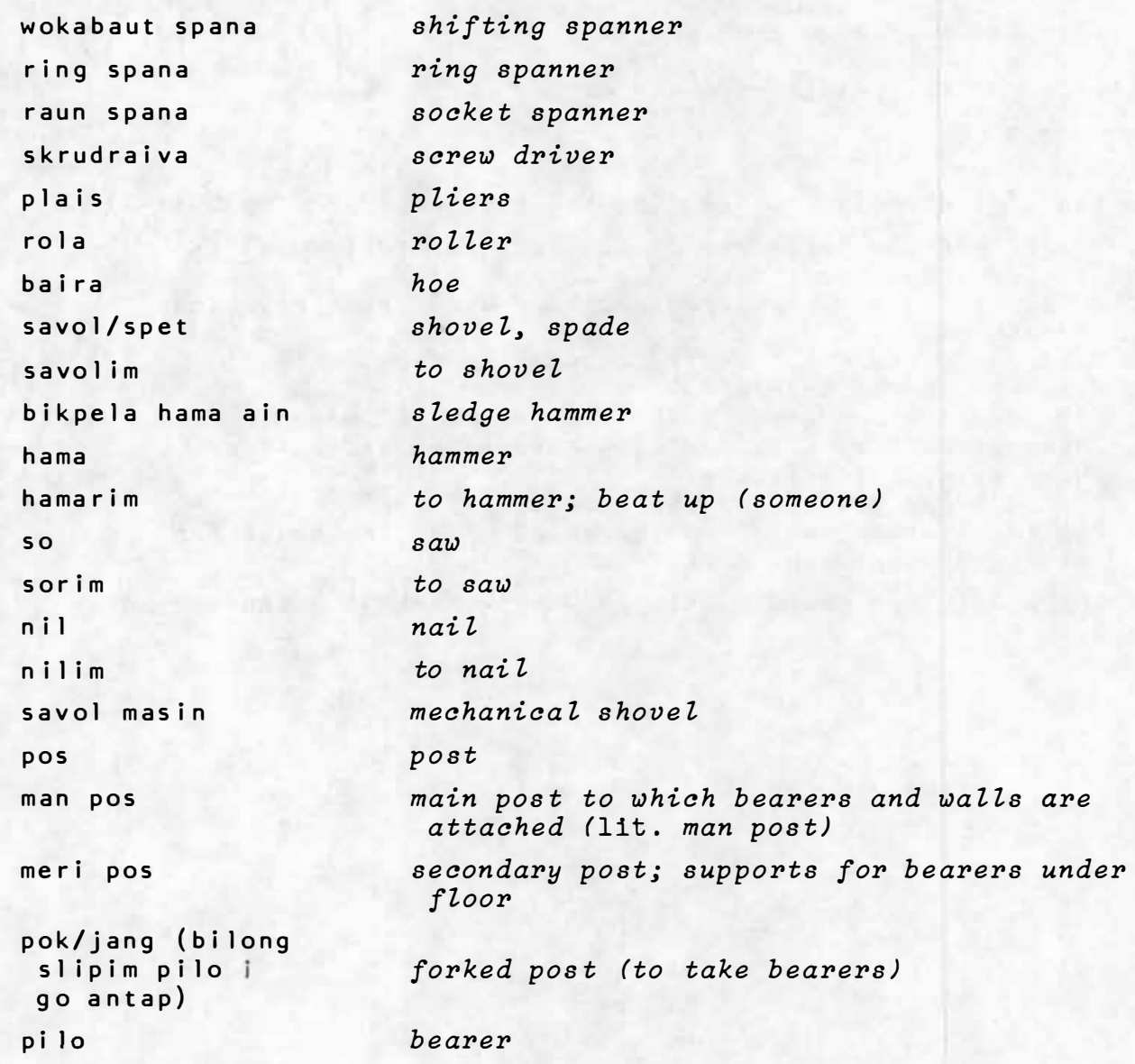

\section{CLASSROOM EXERCISES}

1. Get students to describe orally how to make tea in Pidgin (cf. Text to Unit 7). Then students can write their own account for correction by teacher.

2. Pretend you are a New Guinean and tell this story into a taperecorder. Then you or a friend transcribe what you said and check it off with a teacher. Here is the story:

\section{A RAT STORY}

This is a story about rats. It's made-up. Once upon a time some rats lived underground. They didn't have any food. And so they used to eat only tree roots. At night they didn't sleep; they sat up and talked a lot. But one night they dug a hole and came up outside, on top, and went and looked forl some new food. They found plenty of ripe bananas about that had fallen down. But one ate something that wasn't any good and his skin swelled up. ${ }^{2}$ So they all returned underground again via the hole they had come up. 3 They followed the fat one. They're there. That's the end.

$1_{\text {painim }}=$ to look for, and painim pinis = to find.

[footnotes continued overleaf] 
${ }^{2}$ Literally become fat or come up fat.

$3_{B e}$ careful of the relative clause here.

3. Yu tanim ol dispela hap tok long tok Pisin. (Based on Unit 2)

1. You(2) put the leftovers in the refrigerator!

11. Is there any Zemon drink left?

111. I like to have Worcestershire sauce with fresh eggs and capsicum.

iv. Your cup of tea is standing beside the duck.

v. How much is the dessert?

vi. Aso gave the condensed milk back to the old woman.

vi1. Thirtyseven Europeans want to leave Papua New Guinea.

vi1i. Where are the tea-leaves?

ix. The cook-boy got rid of the shoulder of pork.

$x$. The two of them see something small under the house for visiting Government officials.

4. Do the Pidgin crossword puzzle in Wantok Namba 6. (Answer in Namba 8) 


\section{UNIT 9}

\section{CONVERSATION}

\section{Long Wok}

Long Fonde bosboi i kam bek gen bilong lukim wok bilong tupela wanwok. Taim em i kam i lukim Dogare $i$ sindaun tanim smok $i$ stap:

Bosbo1: He, yu mekim wanem?

Dogare: Nogat, mi sindaun kisim win liklik tasol.

Bosbo1: Yu lesbaga tru. Yu sanap. Sabilobo i stap we?

Dogare: Em i wok i stap yet.

Bosbo1: Yutupela i wokim baret pinis o nogat?

Dogare: Nogat, mitupela i wokim em i stap yet.

Bosbo1: 01 sem wanem? Mi ting yutupela i bin sindaun nating i stap a?

Dogare: Nogat, mitupela i laik i wokim baret hariap tasol graun i hat ${ }^{2}$ tumas.

Bosboi: Orait, yutupela harim! Taim yutupela i wokim pinis dispela baret yutupela go kisim pe bilong yutupela long masta, save? ${ }^{3}$

Dogare and Sabilobo: Mitupela i save.
On Thursday the overseer came back again to see how the two workers were doing. When he was coming he saw Dogare sitting down rolling a smoke:

Hey, what are you doing?

Nothing, I'm just sitting down for a bit of a spelz.

You're a Zoafer. Stand up!

Where's sabilobo?

He's still working.

Have you two finished digging

the trench or not?

No we're stizl doing it.

Why? It occurs to me that you two have been sitting down for no good reason heh?

No, we wanted to do it quickly but the ground is too hard.

ok, listen you two! When you've finished this go and get your pay from the manager, understand?

We get it. [footnotes overleaf] 
Dogare: Tasol bai mitupela i kisim narapela wok o wanem?

Bosbo1: Mi no save, em samting bilong masta.

Olsem na tupela i wok strong bilong pinisim wok.
But will we get other work or what?

I don't know. That's the manager's business.

And so the two worked hard in order to finish the job.

[Musik ${ }^{4}$ ]
USEFUL EXPRESSIONS

Yu save smok?

Nogat, mi misinari ia! 5

Oke, mekim save wok!

Oke, mekim save kaikai!
Are you a smoker?

No, I'm a missionary (meaning that I don't do anything bad like that).

Work hard! (11t. punish the work)

Eat up we Zl! (11t. punish the food)

${ }^{1}$ Note the significance of $i$ stap in this sentence. Dogare uses it here to lyingly suggest that he is actually still working even though the Bosboi caught him sitting down rolling a cigarette (when he should have been working). If Dogare had merely wanted to indicate that the trench was still unfinished and that he and his wanwok would require time to complete it he need only have said Nogat, mitupela i wokim em yet. See section 9.1 below for more details.

${ }^{2}$ Note that the speaker uses hat for hard here instead of hatpela as taught in section 6.3. However, there is no confusion with hat hot because the speaker's pronunciation of hat hard is longer and more open than for hat hot.

3 This sentence would better have been begun stret long taim.... 4

4 The traditional music heard throughout this tape comes from the Finschafen area of the Huon Peninsula. It is the music of massed dancers carrying skin-topped drums (kundu) at a feast dance. The dance has just begun and the singing is somewhat ragged. The elders can be heard as they move into the circle to chide the dancers and give orders to mark a change of steps and drum rhythms. This recording comes from Sheridan (1958: side l, track 1, item a, Munge).

${ }^{5}$ See the article by Brasch (1971) referred to in the reading list to this volume for further details on the use of misinari and other English words taken over recently into Pidgin but used in new ways. $i a=h i a$ (see footnote 3 to Conversation 6 ). 
VOCABULARY EXPANSION EXERCISES

Exercise 1: Simple Substitution

Frame: Taim em i kam i lukim Dogare i sindaun tanim smok i stap.

$\begin{array}{ll}\text { kirap } & \text { (get up) } \\ \text { redi long go } & \text { (ready to go) } \\ \text { redi long pilai } & \text { (ready to play) } \\ \text { sanap } & \text { (stand up) } \\ \text { pasim stua } & \text { (shut the store) } \\ \text { kam } & \end{array}$

\section{Exercise 2: Simple Substitution}

Frame: Mi sindaun kisim win liklik tasol.

$\begin{array}{ll}\text { sikrapim skin bilong mi } & \text { (scratch my skin) } \\ \text { traut } & \text { (vomit) } \\ \text { ritim "Wantok" } & \text { (read Wantok) } \\ \text { smok } & \text { (smoke) } \\ \text { waswas } & \text { (washing myself) } \\ \text { kisim win } & \end{array}$

Exercise 3: Simple Substitution

Frame: Em i wok i stap yet.

$\begin{array}{ll}\text { driman } & \text { (dream) } \\ \text { lukim driman } & \text { (have a dream) } \\ \text { stori } & \text { (telling a story) } \\ \text { kukim kunai } & \text { (burn kunai grass) } \\ \text { rabim lek } & \text { (rub (his) leg) } \\ \text { subim ka go } & \text { (pushing a car) } \\ \text { lus } & \text { (lost) } \\ \text { lap } & \text { (laugh) } \\ \text { wok } & \end{array}$

Exercise 4: Simple Substitution

Frame: Yutupela i wokim baret pinis o nogat?

sekan

painim mani

kukim kunai

mumuim kaukau (dream)

a ream

(burn kunai grass)

(rub (his) leg)

a car

(2ost)

(laugh) (shake hands)

(find the money)

(burn kunai grass)

(cook sweetpotato in ground oven)

\footnotetext{
${ }^{1}$ Car is often spelled kar. Cf. Mihalic (1971:106) where ka is alphabetically out of order.
} 
Yutupela mumuim kaukau pinis o nogat?

$\begin{array}{ll}\text { planim man } & \text { (bury man) } \\ \text { lusim tingting } & \text { (forget) } \\ \text { pait } & \text { (fight) }\end{array}$

wokim baret

Exercise 5: Simple Substitution

Frame: Graun i hat tumas.

$\begin{array}{ll}\text { kol } & \text { (cold) } \\ \text { strong } & \text { (tough, stubborn) } \\ \text { wet } & \text { (wet) } \\ \text { malomalo } & \text { (soft) } \\ \text { doti } & \text { (dirty) } \\ \text { hevi } & \text { (heavy) } \\ \text { wel } & \text { (slippery) } \\ \text { hat } & \text { (hard) }\end{array}$

\subsection{VERB + I STAP: Continuous Action}

I stap following a verb indicates that the action is in progress or is continuingl at the time referred to.2

Examples :

Dogare i sindaun tanim smok i stap.

Dogare is/was sitting down rolling

$(\text { Taim... })^{3}$ bai Dogare i sindaun a smoke (at the time referred to e (sewhere).

tanim smok i stap.

(When...such and such occurs) Dogare will be sitting down rolling a smoke.

(Taim...) Dogare i (bin) sindaun

(When...such and such occurred)

tan im smok i stap. Dogare was sitting down rolling a smoke.

If the action has been in progress for sometime and one wants to emphasise that it is still in progress at the time referred to then yet still is placed immediately after or before i stap,e.g.,

Em i wok i stap yet.

Em i wok yet i stap. He was/is stizl working.

Finally, i stap may occur in non-verbal predicates, in which case it indicates the continuity of some state. For example, if asked a question like Dogare i mekim wanem i stap nau? What's Dogare doing these days? one would answer $\mathrm{Em} i \mathrm{t}$ isa $\mathrm{i}$ stap yet He's still (being) a teacher or if asked a question like Long wanem taim Dogare i bin wokim dispela haus? one might answer Long taim em i bin tisa i stap yet when he was still a teacher.

${ }^{1}$ Alternatively stap may be placed before the verb but that will not be drilled in these lessons. See Wurm (1971:39). 
2 Time is, as already discussed, marked in Pidgin by adverbs (e.g., tumara, asde - see Section 1.2) or forms like bai (future - Section 4.1) and bin (past - Section 5.3).

$3_{\text {See section }} 9.3$ below for time clauses.

Practice Drills

Exercise 1: Simple Substitution

Frame: Mi wetim bas i stap.

(wok sip, kaikai saksak, planim taro, brumim ples, katim gras, wetim bas)

Exercise 2: Simple Substitution

Frame: Husat i sanap i stap yet?

(spak long pati, sapim kanu, sut long kapul, raitim pas, singsing raun, sanap)

Exercise 3: Answer the following questions using the cues provided:

1. Husat i subimka i go i stap?

(ol lapun meri)

01 lapun meri i subim ka i go i stap.

2. Em i mekim wanem samting i stap? (sapim kanu)

Em i sapim kanu i stap.

3. Em olgeta i pilai susap i stap we?

Em olgeta i pilai susap $i$ stap long haus kuk.

4. Papa bilong yu $i$ wok $i$ stap yet long ples bilong yu? (yesa) Yesa, papa bilong mi $i$ wok $i$ stap yet long ples bilong mi.

5. Yu kukboi i stap yet o nogat?

(nogat)

Nogat, mi no kukboi i stap yet.

Exercise 4: Add yet to the following sentences after $i$ stap to show that the action or state referred to is still going on or still exists. Ready?

1. Mama bilong dispela pikinini em i sik i stap (yet). (pause)

2. 01 spakman i slip i stap (yet) long kalabus. ${ }^{1}$

(pause)

3. Mipela i bilasim het bilong mipela i stap (yet).

(pause)

4. Husat i tisa i stap (yet) em ol i ken kam insait long pati hia.

(pause)

5. Olgeta pikinini i no amamas i stap (yet) long skul. (pause)

$I_{\text {kalabus }}=$ prison. 


\section{Evaluation Exercise}

1. How would you tell someone in Pidgin that a dog is still in the process of stealing his chicken.

Wanpela dok i stilim kakaruk bilong yu i stap yet.

2. How would you tell him that some of the small children are playing guitars.

Sampela liklik pikinini i paitimgita i stap.

3. How would you tell him that his money is not lost, it is still being held in the bank.

Mani bilong yu i no lus; ol i holimem i stap yet

long beng.

4. How would you tell him that all the boys are bathing. (pause)

olgeta manki $i$ waswas $i$ stap.

5. How would you tell him that the bus is still coming along the road.

Bas i kam i stap yet long rot.

\subsection{VERB + PINIS: Completed Actions}

Pinis (and the more intensive form pinis tru) following a verb indicates that the action is finished, ended or completed. E.g.,

Yupela i wokim baret pinis o nogat?

Yesa, mipela i wokim baret pinis (tru).

Mi sutim pik pinis (tru).
Have you fellows finished digging the trench or not? Have you fellows dug the trench or not?

Yes, we have surely (or really) dug the trench.

I (reazly) shot the pig.

There is some allowable optional variation in the position of pinis (tru) relative to the verb if there are objects or other elements following the verb, as the following examples show.l The general rule is, however, that pinis should not become too far removed from the verb it modifies.

Mi sutim wanpela pik pinis.

Mi sutim pinis wanpela pik.

$I$ (have) shot a pig.

Em i skulimmi pinis long tok Pisin.

Em i skulim mi long tok Pisin pinis.

He (has) taught me Pidgin.

01 i givim pik pinis long mi. 01 i givim mi pik pinis.

They gave/have given me the pig.

${ }^{1}$ students should consult Wurm (1971:39-40) for further details. 
Practice Drills

Exercise 1: Simple Substitution

Frame: Em tupela i slip pinis long bikbus.

(wok, pispis, dai, go bek, traut, slip)

\section{Exercise 2: Simple Substitution}

Frame: Husat i kolim nem bilong mi pinis?

(pasim rot, brukim kiau, go sutim welpik, kam

bilasim yupela, kolim nem bilong $\mathrm{mi}$ )

Exercise 3: Simple Substitution

Frame: Dogare i givim kaikal pinis long MALOLo.

(hankisip, tudola, su gumi, faivsen, laplap, kaikai)

Exercise 4: Simple Substitution

Frame: Dogare i givim em kaikai pinis.

(hankisip, tudola, su gumi, faivsen, laplap, kaikai)

Exercise 5: Repeat the following sentences changing the proper name at the end into a pronoun and moving it in next to the verb. For example, if the instructor were to say 01 i givim mani pinis long MALOLO your answer should be 01 i givim em mani pinis. Ready?

1. Husat i givim klos pinis long Wanipe?

(pause)

Husat i givimem klos pinis?

2. Mipela i soim kotren bilong yu pinis long Malolo. (pause)

Mipela i soim em kotren bilong yu pinis.

3. 01 i bringim poteto i kam pinis long Masta Sak. (pause)

01 i bringim em poteto i kam pinis.

4. Yupela i no givim ol dispela bis pinis long Dogare. (pause)

Yupela i no givimem ol dispela bis pinis.

5. Em i soim wilwil pinis long MALOLO o nogat? (pause)

Em i soim em wilwil pinis o nogat?

Exercise 6: Repeat the following sentences changing $i$ stap to plnis so as to indicate that the action has changed from a continuing one to a completed one. Ready?

1. Wanipe i givimbek senis i stap long brata bilongen. (pause) Wanipe i givim bek senis pinis long brata bilongen. 
2. Stuakipa i no pasim stua i stap.

(pause)

stuakipa i no pasim stua pinis.

3. 01 dispela pik i slip i stap insait long haus.

(pause)

01 dispela pik i slip pinis insait long haus.

4. Haumas manmeri i lap i stap long dispela pikinini meri $\mathrm{h}$ i a?

(pause)

Haumas manmeri i lap pinis long dispela pikinini meri hla?

5. Balus i nokisim kago i kam i stap.

(pause)

Balus i no kisim kago i kam pinis.

\section{Sentence Conjunction with pinis}

An important use of pinis is to join sentences in a connected discourse to express the ldea of after doing such and such someone did so and so. This is done by repeating the last verb in the previous sentence and adding pinis to 1t. This verb + pinis combination acts as introduction to the next sentence. E.g.,

Tupela meri i klirim graun long ples bilong tupela. Klirim pinis, tupela i planim taro.

Kap i kapsait long tebol na i bruk. Bruk pinis masta i kam lukim em.

Generally too this verb + pinis combination will be followed by orait then. For example,

Yu boilim rais pastaim. Boilim Boil the rice first. After that, pinis, orait yu kapsaitim em long kari. tip it into the curry.

Exercise 7: In this exercise you will hear two sentences in sequence. The second one begins with bihain afterwards, later on. You have to replace this with a verb plus pinis to express the same 1dea. For example, if the instructor says Em i kam. Bihain, em i kaikai He came. Afterwards he ate your answer should be $\mathrm{Em} i \mathrm{kam}$. Kam pinis, em $\mathbf{i}$ kaikai He came. After coming, he ate. Ready?

1. Misis i kam lukim mipela. Bihain, em i go bek gen long ples bilongen.

(pause)

Misis i kam lukim mipela. Lukim pinis, em i go bek gen long ples bilongen.

2. San i save raun long heven. Bihain, orait em i save gondaun.

(pause)

San i save raun long heven. Raun pinis, orait em $i$ save gondaun.

3. Yu boilim rais pastaim. Bihain, orait yu kapsaitim em long kari.

(pause)

Yu boilim rais pastaim. Boilim pinis, orait yu

kapsaitim em long kari. 
4. Wanipe i go long beng bilong kisim mani. Bihain, em

i wokabaut long taun.

(pause)

Wanipe $i$ go long beng bilong kisim mani. Kisim

pinis, em i wokabaut long taun.

5. Nek bilong mi i kirap drai. Bihain, orait mi traut.

(pause)

Nek bilong mi i kirap drai. Drai pinis, orait mi traut.

6. Yu rausim dispela pipia pastaim. Bihain, yu planim kopi.

(pause)

Yu rausim dispela pipia pastaim. Rausim pinis, yu planim kopi.

\section{Evaluation Exercise}

How would you say the following things in Pidgin? Use $i$ stap or pinis to make it clear that the action is still going on or is

finished. Ready?

1. His maternal uncle is still carving the house post.

(pause)

Kandere bilongen i sapim pos bilong haus i stap yet.

2. Have you harvested the taro or not?

(pause)

Yu kamautim taro pinis o nogat?

3. I alone am finishing this job.

(pause)

Mi wanpela i pinisim dispela wok i stap.

4. My wife is finished putting on her new loin cloth.

(pause)

Meri bilong mi i pasim nupela laplap bilongen pinis.

5. What are you fellows shooting at?

(pause)

Yupela i sut i stap long wanem samting?

\subsection{TIME CLAUSES}

Clauses introduced by taim or long taim express the 1dea of when in Pidgin, e.g.,

(Long) taim em i stap em i When he was (here) he saw

lukim Dogare.

Dogare.

Other related time concepts are expressed in a similar way by the following phrases containing taim:

\section{Introductory Phrase English Example \\ stret long taim as soon as; Stret long taim em i kam em i just when lukim Dogare. \\ As soon as he came he saw Dogare. \\ bihain long taim after}

[continued overleaf] 


\begin{tabular}{|c|c|c|}
\hline Introductory Phrase & English & Example \\
\hline bipo long taim & before & $\begin{array}{l}\text { Bipo long taim em i kam em i } \\
\text { lukim Dogare. } \\
\text { He saw Dogare before he came. }\end{array}$ \\
\hline long wanem taim & $\begin{array}{l}\text { whenever; at } \\
\text { whatever time }\end{array}$ & $\begin{array}{l}\text { Long wanem taim em i kam em i } \\
\text { lukim Dogare. } \\
\text { Whenever (at whatever time) he } \\
\text { came he saw Dogare. }\end{array}$ \\
\hline olgeta & every time & $\begin{array}{l}\text { Olgeta taim em i kam em i lukim } \\
\text { Dogare. } \\
\text { Every time he came he saw Dogare. }\end{array}$ \\
\hline taim...yet & while & $\begin{array}{l}\text { Long taim em i kam i stap yet } \\
\text { em i lukim Dogare. } \\
\text { While he was coming he saw Dogare }\end{array}$ \\
\hline
\end{tabular}

Note that all of these clauses come first in Pidgin sentences whereas the order is much freer in English. Notice also that these are different from those contalning bilong (e.g., taim bilong kaikai) which you should check again in Section 4.3 and in the Supplementary Vocabulary to Unit 4.

Finally note that not every when clause in English becomes a taim clause in Pidgin--in fact few of them do. For example, sentences like When he arrived home he had dinner will be translated differently into Pidgin depending on how one interprets the when in English. For example, if one takes this sentence to mean As soon as he arrived home he had dinner then one would express this idea in Pidgin with Stret long taim em i kamap long haus bilongen em i kaikai. But if, as I think we would normally do in English, we take this to mean $H e$ arrived home and then had dinner then this would be expressed in Pidgin as Em $i$ kamap long haus bilongen na (bihain) em i kaikai or Em $i$ kamap long haus bilongen, orait na em $i$ kaikai. In either case the Pidgin Taim em $i$ kamap long haus bilongen em $i$ kaikai would not be a good translation. Consequently as English speakers you should be particularly careful of falling into the trap of merely substituting taim for when wherever it occurs in English.

Practice Drills

Exercise 1: Simple Substitution

Frame: Taim yu stap long stua, yu baim wanpela kom bilong mi? (hat, kotren, singlis, laplap, kom)

\section{Exercise 2: Simple Substitution}

Frame: Stret long taim san i gondaun, yupela kam hariap!

(bihain long taim, bipo long taim, long wanem taim, stret long taim) 


\section{Exercise 3: Simple Substitution}

Frame: Olgeta taim yutupela i pilai, bilong wanem yu wanpela i save lap?

(ranewe nating, stilim wanpela samting, kirap long sia, krai, bagarapim pilai, lap)

\section{Exercise 4: Simple Substitution}

Frame: Long taim ol i kam i stap yet, balus i pundaun.

(kukim kunai, driman, toktok, subim ka i go, sekan, pait, kam)

Exercise 5: Repeat the following sentences inserting pinis in the time clause so as to indicate that the action referred to in that clause has been or will be completed. Ready?

1. Olgeta taim MALOL.O i kukim rais (pinis) Wanipe i kam toktok wantaim em.

2. Bihain long taim dispela man i bekim tok long masta (pinis), masta i paitim em.

3. Stret long taim mi baim wilwil (pinis) ol i laik i wokabaut longen.

4. Bipo long taimmeri i bekim pas long mi (pinis) mi lusim taun i go long ples.

5. Bihain long taim ren i pundaun (pinis) graun bai i kamap ma lomalo.

\section{Evaluation Exercises}

Exercise 1: Give the English equivalents of the following sentences.

1. Taim yu bin stap long Goroka yu wok wantaim husat?

When you were in Goroka whom did you work with?

2. Stret long taim mi pispis blut mi kam hariap long haus sik. As soon as I urinated blood I came quickly to the hospital.

3. Taim em i wetim pasindia trak i stap yet em i ritim "Wantok". While he was waiting for the passenger truck he was reading Wantok.

4. Long wanem taim masta bai em i kam yu go askim em long pe bilong yu.

Whenever (= at whatever time) the European man comes you go and ask him about your pay.

5. Bihain long taim ol i stori pinis yumi i ken smok.

After they have told their stories we are allowed to smoke.

6. Olgeta taim em i sikrapim lek bilong mi, mi lap.

Every time he scratches my leg I Zaugh. 
7. Bipo long taim ol wetman i kam long Papua Niu Gini mipela i stap nating; nogat wok, nogat mani.

Before the European came to Papua and New Guinea we (excl.) had nothing--no work, no money.

8. Stret long taim yu sutim kapul pinis yu kukim gras bilongen.

As soon as you have shot the possum burn off its fur.

9. Long taim mi sindaun kisim win i stap yet mi paitim gita.

While I was sitting down having a spell I played the guitar.

10. Long taim graun i wet ol i planim rais.

When the ground is wet they plant (the) rice.

Exercise 2: How would you say the following things in Pidgin:

1. As soon as it dies you (pl.) bury it!

stret long taim em i dai pinis yupela planim em!

2. When the shirt tore I got rid of it.

siot i bruk na mi rausim em.

3. Before I arrived in Papua and New Guinea I used to live in Australia.

Bipo long taim mi kamap long Papua Niu Gini mi save stap

long ostrelya.

4. As soon as the moon has gone down let us abduct the girl, heh?

Stret long taim mun i gondaun pinis yumi stilim meri a?

5. Whenever you vomit drink a small amount of milk! Understand?

Long wanem taim yu traut, yu dring liklik susu! Save?

Exercise 3: In this exercise you will hear pairs of sentences which have the same endings but different beginnings. Listen to them and then write down on a plece of scrap paper what the differences between them are in English. Use your pause button to hold the machine while you work. Then check your answers against the translations given in your book. If you do not score well repeat the exercise. Ready?

1a. Long taim bilong ren mipela i slip long ples.

In the rainy season we (excl.) sleep in the vilzage.

b. Long taim ren i kam mipela i slip long ples.

When rain comes we sleep in the village.

2a. Long taim bilong kaikai yu no ken toktok.

During meal time you must not talk.

b. Long taim mipela i kaikai yu no ken toktok.

Wher: we are eating you must not talk. 
3a. Long taim bilong kirap long slip ol pisin i singaut.

When it's time to get up the birds call out.

b. Long taim ol i kirap long slip ol pisin i singaut.

When they are getting up the birds are calling out.

4a. Long taim bilong san ol i wok.

In the dry season they work.

b. Long taimsan i lait ol i wok.

When the sun shines they work.

5a. Long taim bilong haiwara ol i no sutim pukpuk.

In the flood season they do not shoot crocodiles.

b. Long taim haiwara i kamap ol i no sutim pukpuk.

When the flood arrives they do not shoot crocodiles.

\subsection{MORE ON ADJESTIVES (Noun Followers)}

In Section 6.3 we saw that typical adjectives in Pidgin are marked by -pela and come before the noun they qualify. However, there are other adjectives which are not marked by -pela and which come after the noun. You have already had many of these, e.g.,

$\begin{array}{ll}\text { (graun) bruk } & \text { broken (ground) } \\ \text { (tok) giaman } & \text { false (talk) } \\ \text { (ples) hait } & \text { secret/hidden (place) } \\ \text { (bokis) nating } & \text { empty (box) } \\ \text { (samting) nogut } & \text { (something) bad } \\ \text { (tok) Inglis } & \text { English (language) }\end{array}$

Here are some other common ones which will be drilled below:

$$
\begin{array}{ll}
\text { (ples) daun } & \text { down (place) = valley } \\
\text { (ples) klia } & \text { clear (place) = clearing } \\
\text { (ples) malomalo } & \text { soft (place) = mud } \\
\text { (ples) tambu } & \text { forbidden (place) } \\
\text { (han) kais } & \text { left (hand/side) } \\
\text { (han) sut } & \text { right (hand/side) } \\
\text { (man) kros } & \text { angry (man) } \\
\text { (haus) marit }{ }^{2} & \text { married (quarters) } \\
\text { (banana) mau } & \text { ripe (banana) } \\
\text { (pren) tru } & \text { real/genuine (friend) }
\end{array}
$$

${ }^{1}$ Also said as lephan and raithan respectively. But note also kaisman a left-handed man.

${ }^{2}$ Note, however, that it is more common to say maritman than man marit and that haus marit comes from something like haus bilong manmeri i marit. 


$$
\begin{aligned}
& \begin{array}{l}
\text { (man) yaupas } \\
\text { (man) }{ }^{1} \\
\text { iapas }
\end{array} \text { deaf (man) } \\
& \text { (man) mauspas dumb (man) } \\
& \text { (man) aipas blind (man) } \\
& \text { (masta) Siapan Japanese (mister) }
\end{aligned}
$$

Practice Drills

\section{Exercise 1: Simple Substitution}

Frame: Yu putim banana mau long han kais.

(ples klia, ples hait, han sut, ples tambu, graun malomalo, ples daun, han kais)

\section{Exercise 2: Simple Substitution}

Frame: Mi givimbokis nating long man kros hia.

(pren tru bilong mi, meri yaupas, masta siapan, papa aipas bilong yu, man kros)

Exercise 3: Change the following sentences containing relative clauses into ones in which the adjective comes next to the noun. Be prepared for some ending in -pela. Ready?

1. Sampela i stap long ples i daun.

(pause)

Sampela i stap long ples daun.

2. Mi lukim sikau long ples i klia.

(pause)

Mi lukim sikau long ples klia.

3. Dispela man i kukim pinis trausis i klin.

(pause)

Dispela man i kukim pinis klinpela trausis.

4. Olgeta masalai istap insait long graun i malomalo. (pause)

olgeta masalai i stap insait long graun malomalo.

5. Blakbokis i save kaikai banana i mau.

(pause)

Blakbokis i save kaikai banana mau.

6. Yupela kaikai olgeta kaikai i hat.

Yupela kaikai olgeta hatpela kaikai.

7. Mipela i no ken toktok long ples i tambu.

(pause)

Mipela i no ken toktok long ples tambu.

8. Dispela meri i yaupas em i no ken harim tok.

Dispela meri yaupas em i no ken harim tok.

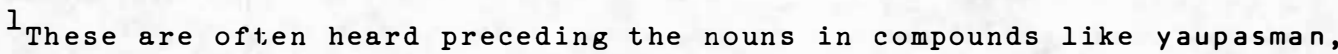
mauspasman and aipasman.
} 
9. Sapos em i baim dispela meri i yangpela, orait bai em i ken slip wantaimem.

Sapos em i baim dispela yangpela meri, orait bai em i ken slip wantaim em.

10. Mama bilong mi i kaikai dispela samting i nogut.

(pause) Mama bilong mi i kaikai dispela samting nogut.

Evaluation Exercise

Give the Pidgin equivalents of the following English expressions:

$\begin{array}{lll}\text { 1. big rat } & \text { (pause) } & \text { bikpela rat } \\ \text { 2. broken cup } & \text { (pause) } & \text { kap bruk } \\ \text { 3. good bread } & \text { (pause) } & \text { gutpela bret } \\ \text { 4. Zong python } & \text { (pause) } & \text { longpela moran } \\ \text { 5. left hand } & \text { (pause) } & \text { han kais } \\ \text { 6. soft food } & \text { (pause) } & \text { kaikai malomalo } \\ \text { 7. black crocodile } & \text { (pause) } & \text { blakpela pukpuk } \\ \text { 8. ripe pawpaw } & \text { (pause) } & \text { popo mau } \\ \text { 9. young bandicoot } & \text { (pause) } \text { yangpela mumut } \\ \text { 10. valley } & \text { (pause) } & \text { ples daun } \\ \text { 11. deaf pig } & \text { (pause) } \text { pik yaupas or pik iapas } \\ \text { 12. honest woman } & \text { (pause) } \text { stretpela meri } \\ \text { 13. fat or large child } & \text { (pause) draipela pikinini } \\ \text { 14. Japanese boy } & \text { (pause) manki siapan } \\ \text { 15. stubborn man } & \text { (pause) strongpela man }\end{array}$

TEXT

Listen to and then transcribe and translate the following description given by Francis, a nineteen-year-old Tumam villager, from the East Sepik. Here is the text:

Orait. Mi laik stori long haus-haus graun. ${ }^{1}$ Taim mipela laik wokim mipela mas digim graun, stretim pinis mipela painim sampela diwai, pos, i kam planim. Pinis, mipela go painim sampela pilo, i kam putim antap. Pinis, mipela i go, katim sampela sapnil no mambu wantaim. Mipela kam putim, mipela putim mambu $i$ gondaun long saitsait ${ }^{2}$ bilongen. Pinis, mipela go painim sampela kanda $i$ kam, pasim--long bun bilong em. Pinis, narapela taim mipela i stap mipela go katim sampela morota. I kam i stap na i stap na narapela taim mipela go painim sampela kaikai long gaden. I kam, redi ${ }^{3}$ nau, mipela putim taim bilong pasim haus. Nau mipela olgeta man i kam bung na mipela man pasim haus na ol meri i kuk. Kuk pinis, mipela pasim haus, mipela kaikai. Na em tasol, liklik stori bilong haus.

[Playing time: 1.25 minutes]

[footnotes overleaf] 
ENGLISH TRANSLATION:

All right. I am going to talk about houses-houses built on the ground. When we want to build (them) we must dig the ground and having prepared it look for some logs, posts, and bring (them) to sink into the ground. After that we go and look for some bearer posts (or joists) and come and put them on top (of the posts). Then we go and cut some lawyer vine and bamboo together. We bring it back and place the bamboo on all sides. Then we go and look for some cane and tie it (the bamboo) to the framework (of the house). Then at another time we go and cut some nipalsago palm leaves (for thatch). We bring it and leave it (lit. it is there) then on another occasion we go and look for food in the garden. When (the food) is ready we put it (aside) ready for the finishing off of the house. Then we all come and the men finish off the house while the women cook. When the cooking's done and we've finished off the house we have a feast. That's all (there is) to (this) small story about houses!

Now to end this unit here are some recordings of slit drums of various kinds. The first one is a garamut from the Sepik, the second is a set of five slit drums from Manus Island. The following details of these are taken from Sheridan (1958):

\section{Garamut}

A slit drum made from a large log signals villagers to an assembly. It is capable of sending detailed messages. It is struck with a light cane bounced end-on, onto the top of the drum.

[side 2, track 4, item f]

\section{Noral Hekiwe}

A set of five slit drums, made of logs. The first three are laid on the ground and played by seated players. These three are played very rapidly with two hardwood strikers.

The fourth slit drum is a much larger log--often eight feet in length. It is usually raised clear of the ground by wooden supports. This helps to bring out the full depth of the bass tone. The fifth slit drum is set in a vertical position--usually suspended from a roof beam of a hut--and this allows it to give off a strange vibrating note when struck by a single curved stick.

The complexities of this vigorous drum orchestra are presented for this record in six interesting figures. Feasting and bride price ceremonies are the best occasions to hear the Manus drums.

[side 2, track 8]

\footnotetext{
${ }^{1}$ Normally haus graun would be translated as mud house (cf. sospen graun clay pot) but here it appears to be used to describe a house built on the ground.

2 saitsait $=$ on all sides

3 redi is proncunced rendi.
} 


\section{SUPPLEMENTARY VOCABULARY}

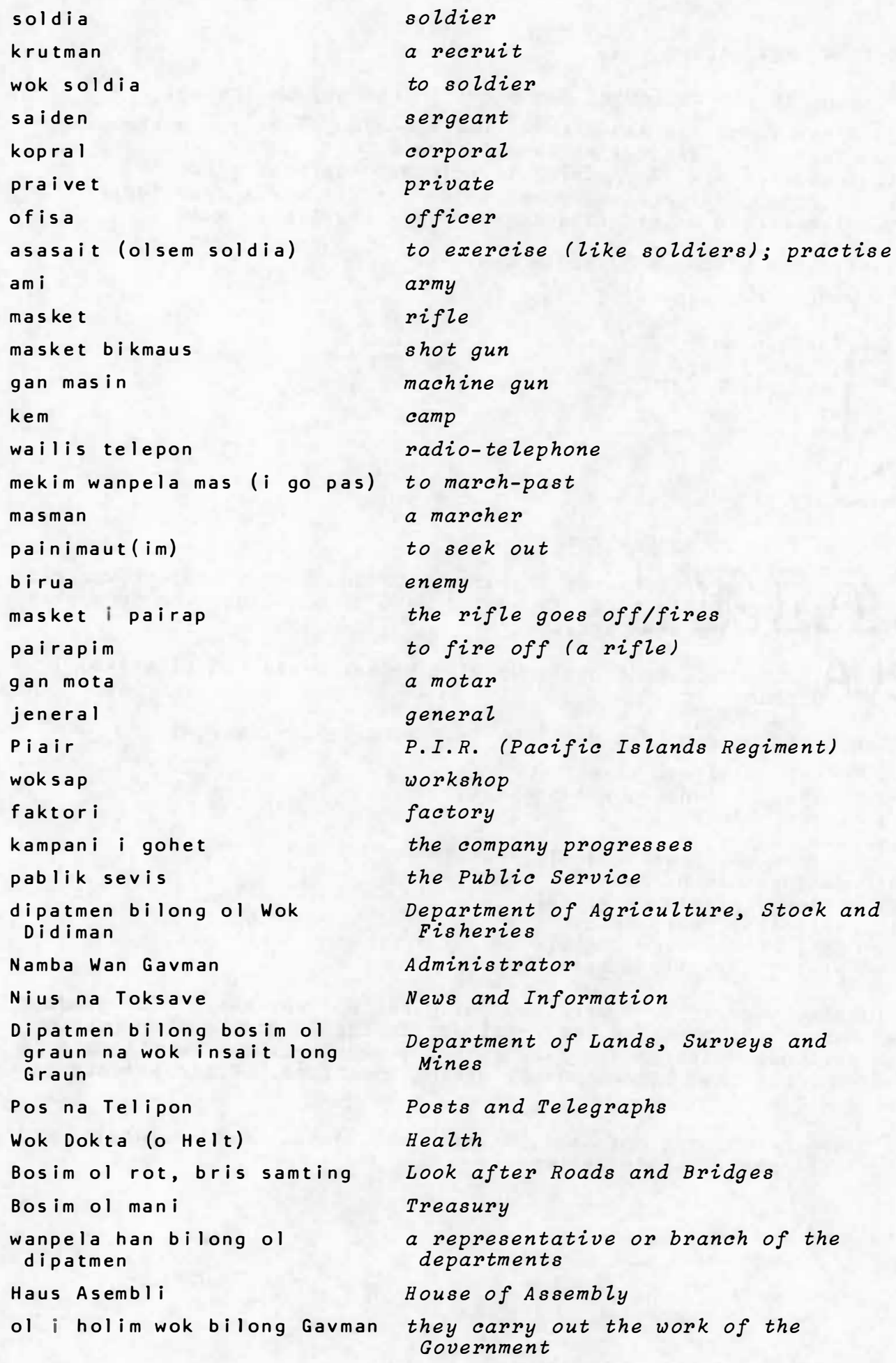


See Wantok, Namba 28, Trinde Septemba 15, 1971, pes 8-11 for related reading.

\section{CLASSROOM EXERCISES}

1. Finish off the following sentences in the way indicated:

1. Stret long taim san i kamap (we (2) go and look for mushrooms).

11. (When it's raining) mi wanpela i wok.

111. (Whenever you(3) vomit) yutripela go long haus sik.

1v. (As soon as the young woman sits down let us(2) grab her.)

v. Olgeta taim mi les (the teacher gets angry with me).

2. Raitim nem bilong ol dispela samting:

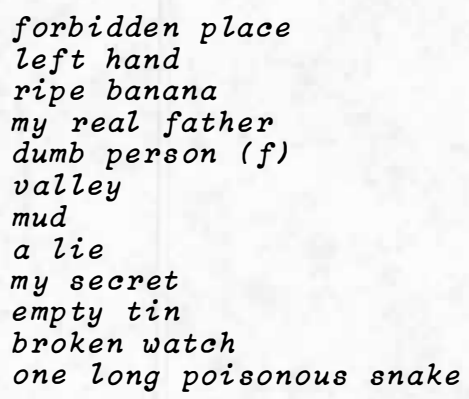

3. Teacher gives out several picture cards and asks a student who has one to describe what is on his to the rest of the class who draw what is described. Discuss results.

4. What is the difference between 01 i kaikai pinis and 01 kaikai i pinis? Discuss.

5. Make Pidgin sentences with the following sets of words:

1. kirap, samting, save

11. i stap, bilongen, kukim kunai

111. subim, klostu

iv. Ius, bai

v. liklik rot, pasim, em i bihainim yu

vi. gen, painim pinis

vil. bilong, planim meri, taim

viil. malomalo, inap, inap

ix. gen, bilong wanem, givim

$x$. pinis, stret long taim, haus

6. Language Game. What were you doing while I was away? One student goes out of the room and the remainder decide on some action (taken from vocabulary learned so far). When student returns he attempts to find out what that action was by asking questions. Class assists by miming the action.

7. Give the opposite of: kol, strong, wet, doti, hevi, malomalo, and illustrate their use in sentences. 


\section{UNIT 10}

CONVERSATI ON

\section{Long Kisim Win}

Bihain long taim tupela wanwok i pinisim wok tupela i go bek long haus bilong brata bilong Dogare. Wanipe: Yutupela i kisim bikpela pe pinis?

Dogare: Nogat, liklik moa yet tasol. 01 masta $i$ no save givim bikpela pe long yumi ol kanaka.

olsem na Dogare i kirap pulim buai long brata bilongen.

Dogare: 0 brata mi stap i dai long buai. I gat liklik i stap long bilum bilong yu?

Wanipe: 0 sori, i no gat, i pinis olgeta.

Dogare: Ating MALOLO i gat sampela?

Wanipe: MALOLO i gat o i no gat, mi no save. Yu go askim e m.

Orait na Dogare i go askim em na i kam bek gen.

Dogare: MALOLO i tok, "Mi no gat."

Sabilobo: Maski, pren. Sapos yu wet inap long tumora (orait) yu ken i kisim sampela long bung.
After the two workers had finished their job they went back to Dogare's brother's house. Did you two get paid werz?

No, only a pittance. Europeans don't usually pay us natives welz.

And so Dogare began to beg his brother for betel-nut.

Oh brothe'r, I'm dying for some betel-nut. Is there any in your bilum?

Oh sorry, there's none, it's completely finished.

Perhaps MALOLO has some?

I don't know, she could have. you go and ask her.

So Dogare went and asked her and came back again.

MALOLO said she hasn't got any.

Nevermind friend. If you wait until tomorrow you will get some at the market. [continued overleaf]

[footnotes overleaf] 
Dogare: Tru, tasol mi ting mi i That's true but I think I'Zl

dai pastaim.

die first.

olsem na tripela i sindaun toktok And so the three sat down and

i stap.

talked.

[Musik ${ }^{2}$ ]

USEFUL EXPRESSIONS

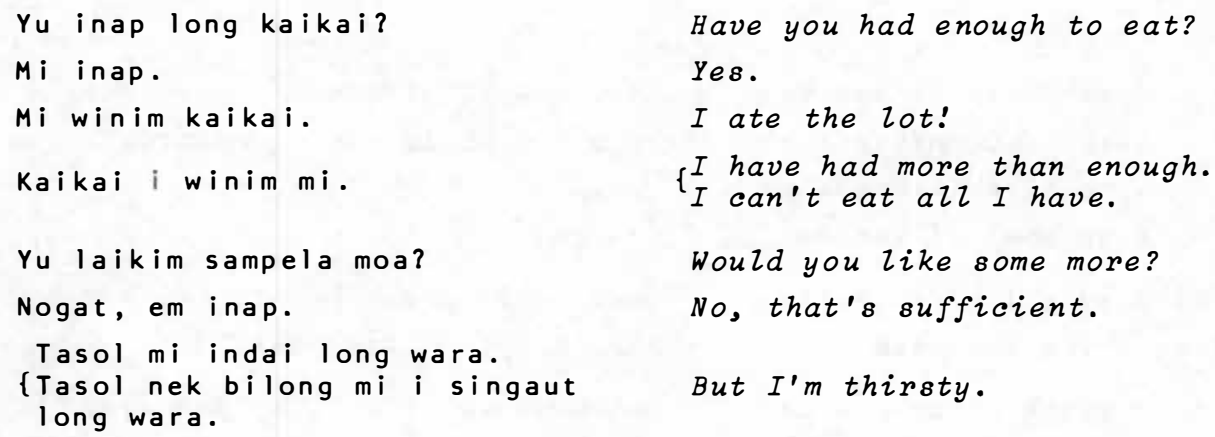

VOCABULARY EXPANSION EXERCISES

Exercise 1: Simple Substitution

Frame: Sapos yu wet inap long tumora, orait yu ken i kisim sampela long bung.

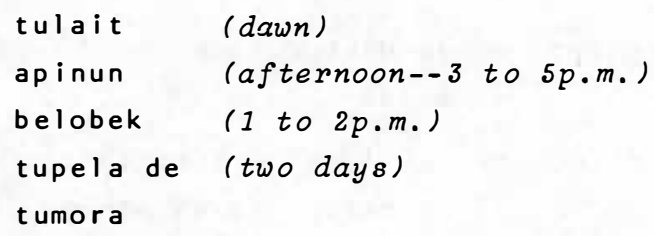

Exercise 2: Simple Substitution

Frame: I gat liklik buai i stap long bilum bilong yu?

$\begin{array}{ll}\text { kamban } & \text { ( lime) } \\ \text { lip daka } & \text { (leaf of betel pepper) }\end{array}$

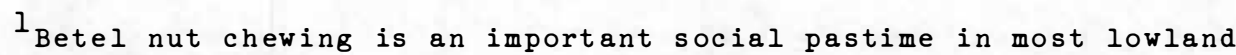
areas of New Guinea. The central ingredient in this is buai, the nut kernel of bilinat, the areca nut. This is chewed with kamban lime (usually carried in a gourd called skin kamban or sel kamban) and the leaves or flowers or parts of the stem or root of the pepper vine, daka, producing a brilliant red pulp in the mouth which eventually leads to serious discoloration of the teeth.

2 The traditional music heard throughout this unit is a dance song sung by the people inland from Aitape. The nasal style of singing is regarded as the true voice in the area. This music comes from sheridan (1958: side 1, track 4, item f). 


$\begin{aligned} \text { I gat liklik } \frac{\text { lip daka i stap long bilum bilong yu? }}{\text { brus }} & \begin{array}{r}\text { (Zeaf tobacco) } \\ \text { stik tabak } \\ \text { sigaret } \\ \text { buai }\end{array} \\ \text { (stick tobacco) } & \text { (cigarettes) }\end{aligned}$

Exercise 3: Simple Substitution

Frame: 01 masta i no save givim bikpela pe long yumi ol kanaka.

$\begin{array}{ll}\text { tenkyu } & \text { (give thanks to) } \\ \text { bilip } & \text { (believe (in)) } \\ \text { bikmaus } & \text { (yelzat; shout at) } \\ \text { givimgude } & \text { (greet) } \\ \text { antapimprais } & \text { (increase the price) } \\ \text { givim gutpela kaikai } & \text { (give good food) } \\ \text { givim bikpela pe } & \end{array}$

Exercise 4: Simple Substitution

Frame: Ating MALOLO i gat sampela?

$\begin{array}{ll}\text { laikim } & \text { (like) } \\ \text { sodaim } & \text { (repair) } \\ \text { yusim } & \text { (use) } \\ \text { wok long painim } & \text { (to be busy looking for) } \\ \text { wari long } & \text { (be worried about) } \\ \text { belgut iong } & \text { (pleased about) } \\ \text { agens long } & \text { (against) } \\ \text { hat long wokim } & \text { (to be keen on making) } \\ \text { gat } & \end{array}$

Exercise 5: Simple Substitution

Frame: Nogat, em i liklik moa yet tasol.

$\begin{array}{ll}\text { bikpela } & \text { (big) } \\ \text { malomalo } & \text { (soft) } \\ \text { strongpela } & \text { (stubborn) } \\ \text { antap } & \text { (high) }\end{array}$

liklik

INote that laikim to like acts like any other transitive verb marked
by -im, and is different in use from laik i + Verb to want to do some-
thing. 
10.1 KEN I + VERB: Definite Future ${ }^{1}$

Verbs preceded by ken $i$ indicate actions that are definitely going to be performed. These are to be contrasted with verbs preceded by bai which also indicate actions that are going to be performed though the speaker is less definite about the time at which they are to be performed. See Section 4.1 above.

Example:

Yu ken i kisim sampela long bung. You will (definitely) get some at Bai yu kisim sampela long bung. the market.

You will get some at the market (but it may not be the first time you go).

Ken $i+V e r b$ is also to be distinguished from ken $V$ (permission to do something) presented in Section 7.1 above.

Practice Drills

Exercise 1: Simple Substitution

Frame: Dispela pikinini long hap $i$ ken $i$ sindaun.

(wok, waswas, sanap, kilim i dai mumut, sindaun)

Exercise 2: Progressive Substitution

Frame: Nau mipela i ken i kukim kunai. smok

kandere bilongen

win im mambu

emtupela

kukim kunai

mipela

Exercise 3: Change the following sentences indicating indefinite future action marked by ba $i$ to ones indicating definite future action marked by ken i. Ready?

1. Kandere bilong emtripela bai i tokim yu.

(pause)

kandere bilong emtripela i ken i tokim yu.

2. Haumas man bai i kam?

(pause)

Haumas man i ken i kam?

3. Bai masta i putim ol hanwas long bokis ain.

(pause)

Masta i ken i putim ol hanwas long bokis ain.

${ }^{1}$ Some speakers do not use this form. 
4. Pikinini bilong dispela meri bai i dai.

(pause)

Pikinini bilong dispela meri $i$ ken $i$ dai.

5. Planti kakaruk bai i kam kaikai rais bilong yumi. (pause)

Planti kakaruk i ken i kam kaikai rais bilong yumi.

\section{Evaluation Exercises}

Exercise 1: Listen carefully to the following sentences in which either ken permission or ken $\mathrm{i}$ definite future will occur, and then say what they mean in English.

1. Tupela tasol i ken i sutim pik wantaim mi.

only two (of them) will (definitely) shoot pigs (or the pig) with me.

2. 01 i ken slekim rop.

(pause)

They can (have permission to) slacken the rope.

3. Yu ken i karim dispela bokis i go long ples balus?

Will you (definitely) carry this box to the airfield?

4. Husat i ken lukautim dispela liklik pikinini?

(pause)

Who can (or has permission to) look after this small child?

5. Dispela lapun meri hia em i no ken i ainim klos.

This old woman will (definitely) not iron the clothes.

Exercise 2: Repeat the following sentences and then say what they mean in English.

1. Bilong wanem ol i ken i tambuim rot?

(pause)

Why will they (definitely) make the road or path a prohibited area?

2. Bai yu inap pinisim dispela wok?

(pause)

Will you be able to finish this job/work?

3. Dispela manki hia i gat faivsen, em i ken baim loliwara o nogat?

Can this boy who has five cents buy softdrink or not?

4. Long wanem taim bai ol i kam?

(pause)

When wizl they come?

5. Yu no ken sakim tok bilong ol.

(pause)

you must not disobey them (lit. what they say).

\subsection{GAT: There is/there are}

There are many sentences in Pidgin which have no subjects and which begin with the predicative marker i. For example: 

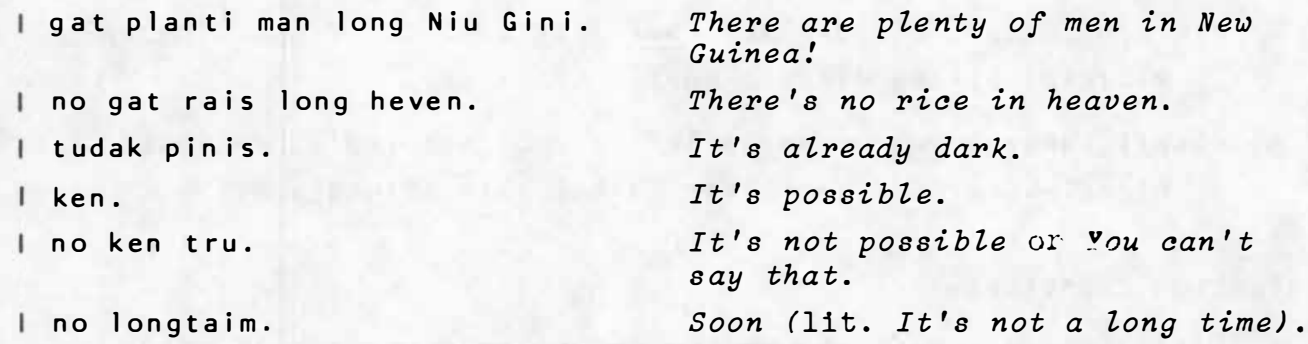

However, most of these are more or less limited to a small range of situations (e.g., as answers to questions or comments on events), excepting $i$ gat which has the freedom of 1ts English equivalents there is, there are. For example:

I gat wanpela draipela meri i

stap long stua.

There is a huge woman in the

I no gat planti kiau bilong mi. store.

Bai i (no) gat nupela wara long dispela hul.

There are not many eggs for me. There will (not) be fresh water in this hole.

Practice Drills

Exercise 1: Simple Substitution

Frame: I gat wanpela garamut i stap arere long haus kiap. (rop, kanu, kundu, welpik, garamut)

\section{Exercise 2: Simple Substitution}

Frame: I no gat tupela siot bilong yu.

(bilong mi, bilongen, bilong ol, bilong yupela, bilong yu)

Exercise 3: Change the following sentences into questions using o nogat?

1. Long Fraide bai i gat sampela nupela kaukau long bung. (pause) Long Fraide bai i gat sampela nupela kaukau long bung o nogat?

2. Bipo long taim kiap i kamap long Goroka i gat kanaka tasol i stap longen.

(pause)

Bipo long taim kiap i kamap long Goroka i gat kanaka tasol i stap longen o nogat?

3. I gat blakbokis long ples bilong yu. ${ }^{1}$ (pause)

I gat blakbokis long ples bilong yu o nogat?

${ }^{1}$ As it stands this sentence means Does the species of animal called Flying Fox occir in your area? If $i$ stap is added after blakbokis the sentence would mean Do flying foxes make their homes in your area or Are there flying foxes living in your area? 
4. Taim yu bin i go long Wewak i gat bulmakau longen.

(pause)

Taim yu bin i go long Wewak i gat bulmakau longen o nogat?

5. I gat masis i stap long hauskuk.

(pause)

I gat masis i stap long hauskuk o nogat?

6. I gat kaikai bilong mi.

(pause)

I gat kaikai bilong mi o nogat?

Evaluation Exercise

How would you say the following things in Pidgin?

1. There is a fowl eating your rice.

(pause)

I gat wanpela kakaruk i kaikai rais bilong yu.

2. There are no letters for you.

(pause)

I no gat pas bilong yu.

3. Are there five patrol boxes in the store or what?

(pause)

I gat faivpela bokis ain ( $i$ stap) long stua o wanem?

4. Are there (such animals as) wild pigs at your place? (pause)

I gat welpik long ples bilong yu?

5. There is an old woman standing on the sidetrack.

(pause)

I gat wanpela lapun meri i sanap long hanrot (i stap).

6. There aren't any potatoes in the kitchen.

(pause)

I no gat poteto ( $i$ stap) long hauskuk.

10.3 INAP LONG: until, up to, as far as

Inap long in Pidgin expresses the idea of until, up to, as far as in English. Often, as in English, this form is used in association with repeated verbs to indicate actions that are repeated or kept on until something else happens.

Examples:

Yu holim em inap long taim kiap i kam.

Hold him until the Government officer comes.

Mi wet, wet, wet inap long taim ai bilong $\mathrm{mi} i$ hevi.

I waited and waited and waited until I got sleepy.

Mi wet, wet, wet inap long Mande. I kept waiting until Monday.

01 i bin hat long wok inap long taim ol i save (ol) i wok nating.

They were keen on working until they found out they were working in vain.

Sampela i antapim prais inap long tudola.

Some increased the price to two dolzars.

Rot i gondaun inap long nambis.

The road goes (down) as far as the beach. 
Dispela wok em i inap long tripela This is three days' work. de.

Mi sik inap long tripela de. I was sick for three days.

Practice Drills

Exercise 1: Simple Substitution

Frame: Maski kambek gen inap long Trinde.

(Sarere, mun 0gas, de namba ten bilong mun Julai, hap pas tri samting, Trinde)

\section{Exercise 2: Progressive Substitution}

Frame: Mi wok long painim naip inap long taim ol i kirapim nok. Mi wok long raitim pas

ol i mumuim kaikai.

Mi wok long pilai kikbal

ol i bilasim haus kiap.

Mi wok long painim naip

ol i kirapim wok.

\section{Evaluation Exercises}

Exercise 1: Repeat the following sentences in Pidgin and say what they mean in English.

1. Graun i guria inap long apinun tru.

(pause)

The ground (or earth) shook until late afternoon.

2. Dispela rot i no go inap long wara Makham.

(pause)

This road doesn't go as far as the Markham River.

3. Mi sindaun sapim kanu; sapim, sapim, sapim inap long taim mi pinisim em.

I sat carving and carving the canoe until I finished it.

I kept on carving the canoe until I finished $i t$.

4. Yupela bihainim pasin bilong mipela inap long taim yupela i save em.

You (pl.) imitate us (excl.) until you know how to do what we are doing.

5. ol Papua Niu Gini i bin hepi inap long taim ol Yuropen i kamap.

Papuans and New Guineans were happy until Europeans arrived.

6. Mipela i agens long wok bus inap long taim yu antapim pe bilong mipela.

We (excl.) are against going (or we refuse to go) on patrol until you have increased our wages. 
7. 01 i bin sik inap long sikspela mun.

(pause)

They have been sick for six months.

Exercise 2: How would you say the following things in Pidgin?

1. I waited and waited and waited until I fell asleep. (pause)

Mi wet, wet, wet inap long taim ai bilong mi i slip pinis.

2. They wizl be keen on working until they find out they are working in vain.

(pause)

Bai ol $i$ hat long wok inap long taim ol i save $i$ wok nating.

3. Chase the pig away as far as the garden fence.

(pause)

Yu ranim pik i go inap long banis bilong gaden.

4. Up until what time shall I stand up?

(pause)

Bai mi sanap inap long wanem taim?

5. Yesterday a wild pig came into the village as far a this house post.

(pause)

Asde wanpela welpik i kam insait long ples inap long

dispela pos bilong haus.

6. All the parents habitually walk for two days to bring food to their children.

(pause)

Olgeta papamama i save wokabaut inap long tupela de

bilong bringim kaikai i kam long pikinini bilong ol.

\subsection{INTENSIFICATION OF AOJECTIVES}

In Pidgin the relative sizes and qualities of things can be intensified by adding liklik little, moa more, moa yet still more, tumas very much, tru really or olgeta completely after the adjective of one's choice. 1 Except for liklik the order between these depends on one's preference or emphasis. For example, tru may be used for very whereas in the following listing moa has been so used.

\section{Examples :}

Mi lukim wanpela moran i longpela. I saw a python which was Zong.

Mi lukim wanpela moran i longpela I saw a python which was fairly liklik.

Zong/moderately Zong.

Mi lukim wanpela moran i longpela I saw a python which was very moa. Zong.

Mi lukim wanpela moran i longpela moa yet.

I saw a python which was very, very long.

Mi lukim wanpela moran i longpela I saw a python which was tumas. extremely long.

Mi lukim wanpela moran i longpela I saw a python which was really tru. Zong.

lother methods are to double the adjective e.g., blakpela blakpela klaut (a) very black cloud, or gutpela gutpela meri (a) very good woman, or alternatively to lengthen the vowel of the adjective involved, e.g., lo:: :ngpela moran very very long python. 
Mi lukim wanpela moran i longpela olgeta.
I saw a python which was unbelievably zong.

Some of these have already been introduced casually into the lessons so far (e.g. tumas, tru) and so should not present much difficulty though they have not been specifically drilled. Note, however, that when adjectives are intensified in this way they must (except for one or two common cases)l come after the noun (if they are not already there) in relative clauses as indicated oy the predicative marker i. Compare, for example, the following pairs of acceptable and nonacceptable sentences:

\section{Adjective only}

1. Mi lukim wanpela longpela moran.

I saw a long python.

2. Maski wokabaut long ples

t ambu.

Don't walk about in a sacred place.

3. Dispela i bikpela haus. This is a big house.
Adjective + liklik

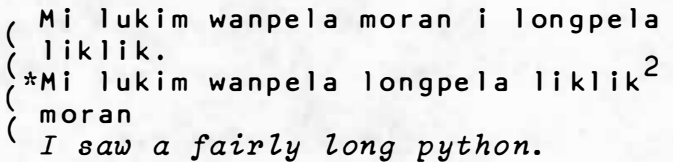

Maski wokabaut long ples i tambu liklik.

* Maski wokabaut long ples tambu liklik.

Don't walk about in a fairly sacred place.

Dispela haus i bikpela liklik. *Dispela i haus i bikpela liklik. * Dispela i bikpela liklik haus. This is a fairly big house.

Before you start the following exercises revise Sections 6.3 and 9.4 above.

\section{Practice Drills}

Exercise 1: Add in the Pidgin words given as cues after the adjectives in the following sentences. Ready?

1. Dispela kaikai i gutpela.

(tru)

(pause)

Dispela kaikai i gutpela tru.

2. Tok bilongen i stret.

$(1 i k l i k) \quad($ pause $)$

Tok bilongen i stret liklik.

3. Dispela ston long hap i raunpela.

(moa)

(pause)

Dispela ston long hap i raunpela moa.

4. Olgeta klos i stap long san i drai.

$(1 i k l i k) \quad$ (pause)

olgeta klos i stap long san i drai liklik.

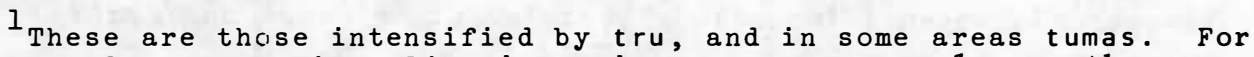
example, expressions like longpela moran tru very long python or bikpela man tru a very big man are acceptable where longpela tru moran or bikpela tru man or longpela moran liklik or bikpela man liklik are not.

2 This could mean, however, I saw a long small snake (that is, of some small variety of snake). 
5. 01 dispela meri i lapun, em ol i stap we? (tru) (pause)

01 dispela meri i lapun tru, em ol i stap we?

Exercise 2: In this exercise you will hear sentences in which adjectives precede nouns. You have to restate these sentences adding in tru. To do this you will have to shift the adjective plus tru to a position behind the noun adding in the predicative marker $i$ as you go. For example, if the instructor were to say Mi lukim wanpela longpela moran your answer should be Mi lukim wanpela moran $i$ longpela tru. Remember, however, that some adjectives will lose - pela in these positions. Ready?

1. Em i laik i maritim dispela yangpela meri.

(pause)

Em i laik i maritim dispela meri i yangpela tru.

2. Husat i sutim dispela blakpela pik?

(pause)

Husat i sutim dispela pik i blakpela tru?

3. Mi sindaun long wanpela hatpela ston na mi kukim as bilong mi.

(pause)

Mi sindaun long wanpela ston i hat tru na mi kukim as bilong $\mathrm{mi}$.

4. Yu no stretpela man; yu man bilong tok giaman tasol. (pause)

Yu no man i stret tru; yu man bilong tok giaman tasol.

5. Yu bringim i kam olgeta strongpela diwai!

(pause)

Yu bringim i kam olgeta diwai i strongpela tru.

Exercise 3: This exercise is the same as the last one except that the adjective is already behind the noun. All you have to do therefore is to add tru and the predicative marker i. Ready?

1. Tupela wara $i$ bung long wanpela ples klia.

(pause)

Tupela wara $i$ bung long wanpela ples $i$ klia tru.

2. Ka bilong $m i$ i pas long graun malomalo.

(pause)

Ka bilong mi i pas long graun i malomalo tru.

3. Yupela i laikim banana mau o nogat?

(pause)

Yupela i laikim banana i mau tru o nogat?

4. Tripela man i pundaun long ples daun.

(pause)

Tripela man i pundaun long ples i daun tru.

5. Stilman i karamapim mani long wanpela siot bruk.

(pause)

Stilman i karamapim mani long wanpela siot i bruk tru.

\section{Evaluation Exercise}

How would you say the following things in Pidgin? Use tru for very in your answers. Ready? 
1. I heard some very bad language.

(pause)

Mi harim sampela tok i nogut tru.

2. All Europeans like very soft food.

(pause)

olgeta Yuropen i laikim kaikai i malomalo tru.

3. No natives live in very wet places.

(pause)

I no gat sampela kanaka i stap long ples i wet tru.

4. I definitely will iron your very clean trousers!

(pause)

Mi ken i ainim trausis bilong yu i klin tru.

5. If you don't like this very hot food put it in the refrigerator.

(pause)

Sapos yu no laikim dispela kaikai i hat tru, orait putim em insait long bokis ais.

6. There are some very high buildings in sydney!

(pause)

I gat sampela haus long Sidni i antap tru.

\subsection{WHETHER CLAUSES}

There is no equivalent word in Pidgin for whether (or if in certain sentences) in English. These ideas are expressed in Pidgin by giving positive and negative sides of the idea in doubt before (or after) giving (or asking) for one's (or someone else's) opinion or judgement about them. That is, the equivalent of the whether clause in English usually comes first but may come last in Pidgin depending on whether one is asking a question or on other factors which we shall not attempt to describe here but will merely leave to the student to get the "feel" for by studying the following examples and working through the exercises given below. In these the student will note, however, that the Pidgin approximates closely in content (but not always in order) the literal translation in English, which, in the examples, is given in brackets.

Examples:

MALOLO i gat o i no gat, mi no save.

(MALOLO has some or has not got some, I don't know.)

I don't know whether MALOLO has got some or not.

Yu lukim balus i pundaun o i no pundaun?

(You saw the plane land or did not land.)

Did you see whether/if the plane landed?

Balus $i$ pundaun o $i$ no pundaun, yu lukim em o nogat?

(The plane landed or did not land, did you see or not?)

Did you see whether the plane landed, or not? or

Did you or did you not see whether the plane landed?

Luluai i askim tultul i tok, "Tude kiap i kam o i no kam?"

(Luluai asked the tultul, "Is the kiap coming today or not coming?)

The Zuluai asked the tultul whether the kiap was coming that day.

Bai em i kam o i no kam, mi no save.

(He will come or he will not come, I don't know.)

I don't know if he will come or not. 
Practice Drills

Exercise 1: Simple Substitution

Frame: MALOLO i gat o $i$ no gat, mi no save.

(redi long pilai, traut, agens long gavman, lukim driman, amamas, gat)

Exercise 2: Progressive Substitution

Frame: 01 i smok o ol i no smok, Dogare i no save. " " " " " " " Wanipe i no askim ol. 01 i ritim "Wantok" o ol i no ritim, " " " " " " " " " " em tupela i no lukim. Welpik i bagarapim gaden o i no bagarapimem," " " "

" $1 "$ " $1 "$ smok o ol i no smok, "

\section{Evaluation Exercises}

Exercise 1: Say what the following Pidgin sentences mean in English:

1. Yu kukim kunai o yu no kukim kunai, masta i no tokim $\mathrm{mi}$.

(pause)

The European did not tell me whether you were to burn the grass or not.

2. Dispela i maritim MALOLo o dispela hia i maritimem, ol i no save.

(pause)

They don't know whether this fellow or this fellow here married MALOLO.

3. Yupela go askim papa bilongen, yu tok, "Buai i pinis, o i no pinis?"

(pause)

You (pl.) go and ask his father whether/if the

betel-nut is finished.

4. 01 i sekan o ol i no sekan, husat i save?

(pause)

Who knows whether they shook hands?

5. Yu kandere bilong mi o yu no kandere bilong mi, maski.(pause)

It doesn't matter whether you are my maternal uncle

or not.

Exercise 2: How would you say the following things in Pidgin using the structures you have just learned? 1

1. Do you know if there is an old man in the village? (pause) Yu save, i gat wanpela lapun man i stap long ples o i no gat.

${ }^{l} A l l$ of these could be shortened by leaving out repetitious parts or by using o no gat for the second part of the whether clause, as, for example, in sentences 1 and 2 . 
2. They asked the teacher whether school was finished. (pause)

01 i askim tisa ol i tok, "Tisa, skul i pinis o i no pinis?"

3. We (excl.) don't know whether you are nine or ten years old.

(pause)

Yu gat nainpela krismas o yu gat tenpela krismas, mipela

i no save.

4. She did not hear whether they were speaking English or Pidgin.

01 i toktok long tok Inglis o ol i toktok long tok Pisin, em i no harim.

5. I don't know whether my mother is sick or not.

(pause)

Mama bilong mi i sik o i no sik, mi no save.

TEXT

Listen to the following story told by a middle-aged speaker from Nambolei village, East Sepik District, and then see how much of it you can transcribe and translate. Here is the story:

Mi laik toktok long stori bilong pik. Mi laik stori long--mi laik stori long pik--long welpik bilong bus. Na taim ol tumbuna bilong mipela na ol papa bilong mipela ol i mekim pasin bilong--pasin bilong yumi long tumbuna. Orait ol i kisim umben, ol i go long bus. 01 i go putim long maus bilong rot, long lek bilong pik ${ }^{1}--1 e k$ bilong pik. orait, ol man i lain long hap, go raunimpik. Pinis, orait ol i krungutim ol tiktik ${ }^{2}-$-ol i krungutim weltiktik ${ }^{3}$ no wanem kain gras insait long bus. Orait ol i rausim dispela ol i krungutim dispela ol gras na ol weltiktik ${ }^{3}$ i kam i kam. 01 i kirapimpik. Orait ol i go i go $i$ go $i$ go $i$ go $i$ go $i$ go $i$ go i go sapos pik i kirap em i go stret $i$ go $i$ go $i$ go $i$ orait em $i$ go stret long umben $i$ stap longen. Em i go stret long umben i stap longen, orait, man bilong was long umben em i holim nau, em i laik taitim. Orait pik islip i stap long umben. Orait, em--em $i$ no indai. Nogat, em i stap. 01 i holim tasol, pik yet i raun raun $i$ go i go i go $i$ go i go go go go orait umben yet hapim ${ }^{4}$ dispela pik. Pundaun. Orait. ol man hia antap long dispela pik ol i pasim. 01 i pasim dispela pik. Orait, em, ol i no sutim na em, ol i pasim nating na karim. Nau wanpela, ol i lukim umben i laik kisim pik hia, laik hamarim ${ }^{5}$ pundaun long graun. Orait, em nau, ol i sutim spia antap long skin ${ }^{6}$ bilong pik. Orait em nau ol i pasim. 01 i pasim nau, karim i kam. Bilong bai ol i kukim na kaikai. 01 i kukim na kaikai nau. Na stori bilong em liklik tasol olsem. Mi toksave long stori bilong pik.

[Playing time: 2.6 minutes]

$\overline{I_{l e k} b i l o n g}$ pik = the pig track (i.e. the track made by the pigs) 
${ }^{2}$ tiktik $=a$ kind of wild sugarcane used for fences, arrow shafts etc. Cf. pitpit.

$3_{\text {weltiktik }}=$ wild wildsugarcane.

4 hapim = to halve--presumably used here to indicate that the basket restricted the full movement of the pig.

$5_{\text {hamarim }}=$ to hammer, belt up, bash, hurt

6 antap long skin= lit. on top of the skin, but what this means here is unknown.

ENGLISH TRANSLATION :

I'm going to tell a story about pigs. I'm going to tell about--I'm going to tell about--about wild pigs. When our ancestors and our fathers had the custom of--our custom (in the time of our ancestors (?). They (used to) get a net (trap) and go into the bush. They (used to) put it at the entrance to a pig track--pig track. Then they (would) make a line (of beaters) over there and chase the pig. Then they (would) bend over the wild sugarcane--they (would) bend over the wild sugarcane or whatever kind of grass there was in the bush. Then they would pull out this (grass)--they (would) bend these grasses and wild sugarcane over and make a track (up to where the speaker was or imagined himself to be). Then they (would) rouse the pig. They (would) go and keep going until suppose the pig got up and went straight and kept going then it would go right into the net and stay there. When it went right into the net and stayed there the man who was there guarding the trap (would) hold it and tighten it and so the pig (would) stay lying down in it. It wasn't dead; it was alive. They'd hold it and the pig itself would keep twisting and turning but the net would restrict it and it would fall over. Then the men who were there standing over it would hold it. They'd hold the pig. They (would) not shoot it but they (would) just truss it up and carry it. Then one (while) they were looking at the net, would (express the) wish of having this pig and of hitting it and knocking it down on the ground. So that's what they'd do (lit. all right, that's the thingl that's it). They'd spear the pig and tie it up and bring it (back) to cook and eat it. Then they'd cook it and eat it. And that's the story of it. It's only short. I've explained about pigs.

Now to end this unit here is another Pidgin song in which a soldier from Moem Barracks laments the death of his father:

$$
\begin{aligned}
& \text { Mi stap long Moem barik } \\
& \text { Mi kisim leta long ples } \\
& \text { Mi stap long Moem barik } \\
& \text { Mi kisim leta long ples }
\end{aligned}
$$




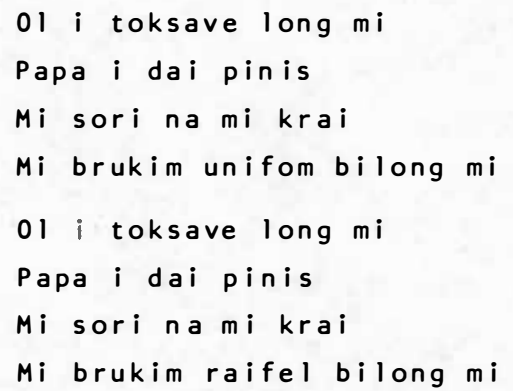

SUPPLEMENTARY VOCABULARY

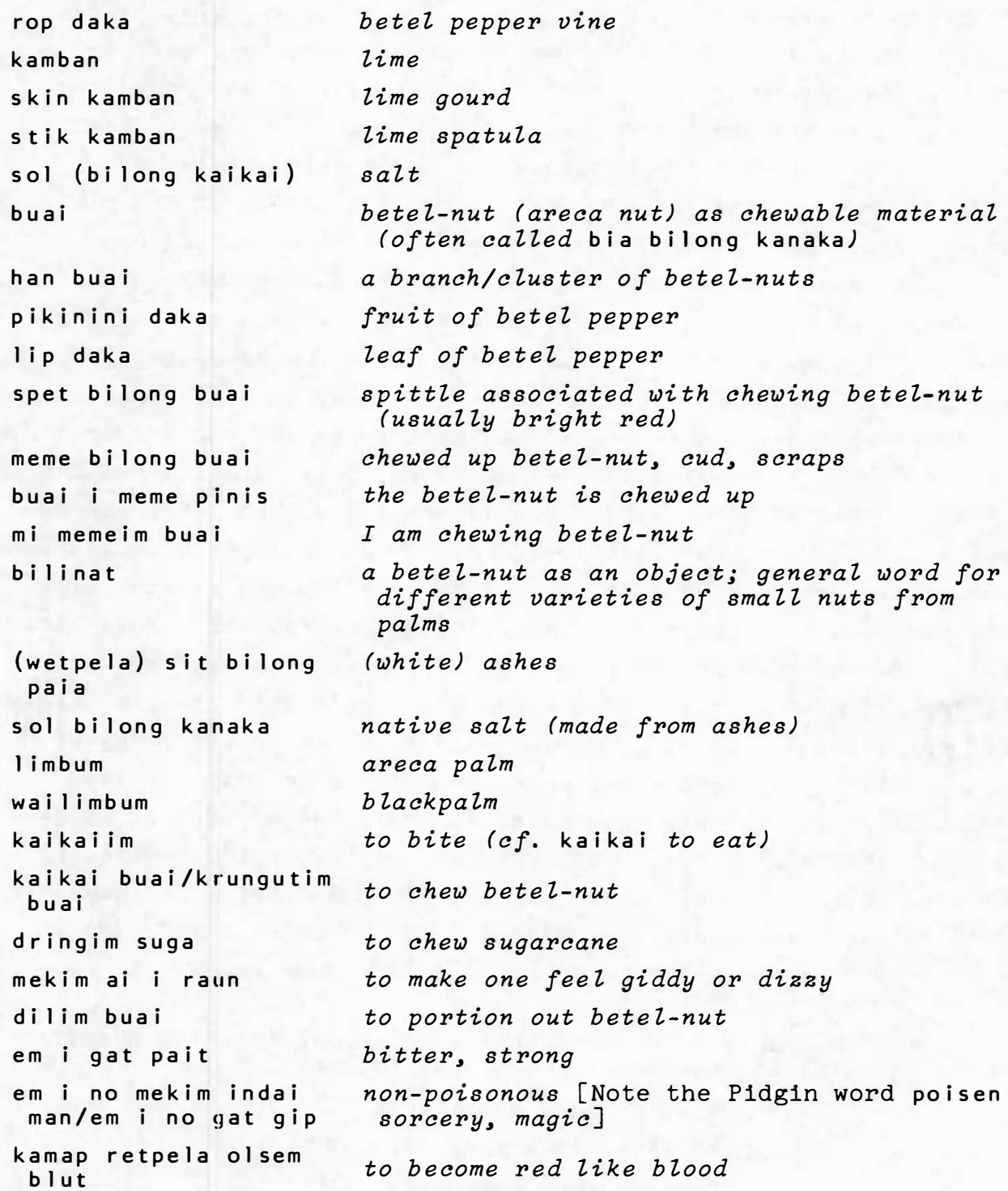




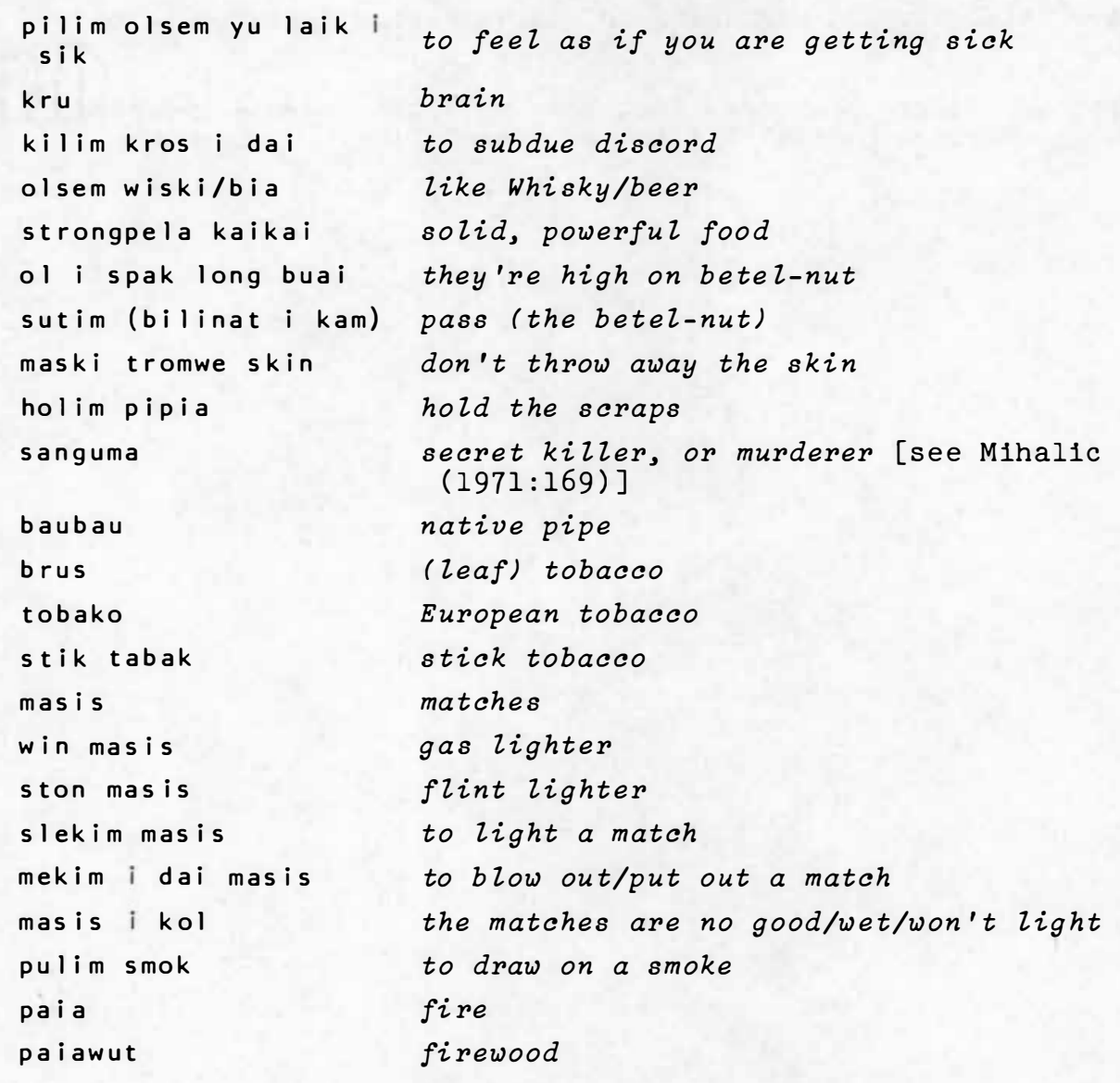

\section{CLASSROOM EXERCISES}

1. Try the following two-way discussions:

(a) Pretend you are a smoker and that you smoke only Malboro filter tips. Explain to someone why you do this and do not smoke some other brand or roll your own from cut tobacco;

(b) Pretend your friend smokes and try to persuade him to give it up;

(c) Pretend you are a chewer of betel-nut. Try to persuade your non-chewer friend to take it up.

2. Work up an advertisement in Pidgin for promoting Papua New Guinea as a tourist attraction.

3. Do the crossword puzzle in Wantok Namba 8. [Answer in Namba 10.]

4. Puppet show. Use to revise Units 1-10.

5. Language Game. Acrostics.

Each letter in a word is used in turn as a starting letter of a word in a sentence but not counting the predicative marker $i, e . g$. , given stap to work with a possible answer is Silas i tok, "Apinun Pita." 
6. Picture Talk. Supply beginning or end to action depicted in a picture.

7. Choose ten Pidgin sentences from the Unit just learned and give students the English equivalents for re-translation. 


\section{UNIT 11}

CON VERSATION

Long Haus Sik

Long wanpela de MALOLO i pilim

sik olsem em i gat malaria na

i go long haus sik.

Doktabo1: Wanem samting?

MALOLO: $0 \mathrm{mi}$ sik nogut tru.

Ating klosap mi dai.

Doktabo1: Bilong wanem?

MALOLO: 0 het bilong $\mathrm{mi}$ i pen na skin tu i guria.

Doktabol: Bel bilong yu i no pen a?

MALOLO: Yesa, em i no pen.

Doktabo1: 0 sori, dispela sik i samting nating. Sapos

yu daunim dispela marasin na ol dispela

liklik kiaukinin, orait ating bai yu kamap nupela gen.

MALOLO: Tenkyu. Tasol mi ting long sut-bai yu givim mi wanpela o nogat?

Doktabo1: Nogat. Mi no save pasin bilong givim sut.

MALOLO: Oloman! Yu doktaboi?

Doktabo1: Mi doktaboi tasol mi no skul tumas long pasin bilong givim sut. Olsem
One day MALOLO felt sick as if she had malaria so she went to the hospital.

What's wrong?

oh, I'm very sick. I must surely be about to die.

Why?

Well my head's aching and $I^{\prime} m$ shivering.

You haven't got a pain in the stomach eh?

No, I haven't.

Don't be alarmed it's nothing much. If you take this medicine and swallow these tablets you'll probably be all right again.

Thank you. But I was wondering about an injection: are you going to give me one or not?

No. I don't know how to give injections.

Gosh, I thought you were supposed to be a medical orderly.

I'm a medical orderly all right but I didn't practise the way to give injections very much [continued overleaf] 


\author{
na mi pret long givim \\ em kranki.
}

MALOLO: Orait. Maski. Mi go.

Doktabol: Holit! Harim! Yu mas

lukautim gut yu yet.

Sapos sik i no slek inap

long tumora orait yu mas

kam bek gen hariap

bilong kisim narapela

marasin. Save?

MALOLO: Mi save.

Olsem na MALOLO i go bek gen long haus bilongen. so I'm scared of giving them wrongly.

ok. Forget it. I'm going.

Hold it! Listen! You must look after yourself well. If the sickness hasn't eased by tomorrow you must come back again quickly to get some other medicine. Understand?

Yes.

And so MALOLO went back home.

\section{$\left[\right.$ Musik $\left.{ }^{1}\right]$}

\section{USEFUL EXPRESSIONS}

Yu bun nating, olsem stik masis.

Yu pus lama.

Yu stik kokonas.

Yu pukpuk man.

Yu binatang.

Yu swit bisket (tru).

Yu drai bisket (tru).
You're very thin, just like a match stick.

You're a sloppy person litt. sea-s(ug).

You're very thin (11t. a coconut stick)

You're a person with grile (i.e., skin is affected by tinea).

you're a naughty child (lit. an insect).

You're a darlinglattractive person.

You're unattractive/beyond your prime.

\footnotetext{
I The traditional music heard on this tape is as follows:

(a) up to the end of the Conversation material:

Nawoga. A canoeman sings as he poles his craft across the shallow sandbanks on his way to the fishing grounds; he is asking the spirits to ensure him a good catch.

(b) elsewhere: [Sheridan (1958: side 2, track 3, item e)]

A warabut. A falsetto voice is used for the singing of a spell. Any other type of voice would lessen the power of its magic.

$$
\text { [Sheridan (1958: side 2, track 4, item e)] }
$$
}




\section{VOCABULARY EXPANSION EXERCISES}

\section{Exercise 1: Simple Substitution}

Frame: Ating klosap mi dai.

$$
\begin{aligned}
& \text { pulap (fulz, satisfied) } \\
& \text { dring wara (drink water) } \\
& \text { kros (angry) } \\
& \text { kaikai planti inap long mi pulap } \\
& \text { (eat sufficient) }
\end{aligned}
$$

da $\mathbf{i}$

\section{Exercise 2: Simple Substitution}

Frame: Het bilong mi i pen na skin tu i guria.

$\begin{array}{ll}\text { Bel bilongen i tantanim } & \text { (he is nauseated) } \\ \text { Tis bilong ol i pen } & \text { (their teeth are paining) } \\ \text { Skrubilong lek bilong mi i lus } & \text { (I am lame) } \\ \text { Nek bilong mi i drai } & \text { (I have a dry throat) }\end{array}$

Het bilong $\mathrm{mi}$ i pen

\section{Exercise 3: Simple Substitution}

Frame: Yu mas lukautim gut yu yet.

$\begin{array}{ll}\text { wasim } & \text { (wash) } \\ \text { bilasim } & \text { (beautify; decorate) } \\ \text { glasim } & \text { (take your temperature) } \\ \text { amamasim } & \text { (be proud of) } \\ \text { karamapim } & \text { (cover up) } \\ \text { lukautim } & \end{array}$

\section{Exercise 4: Simple Substitution}

Frame: Mi no save pasin bilong givim sut.

$$
\begin{array}{ll}
\text { klinim sua } & \text { (dress a wound; clean) } \\
\text { pasim sua } & \text { (bandage a wound or sore) } \\
\text { samapim sua } & \text { (suture a wound) } \\
\text { draivim ka (drive a car) } \\
\text { mekim poisen (make magic) } \\
\text { givim sut }
\end{array}
$$




\section{Exercise 5: Progressive Substitution}

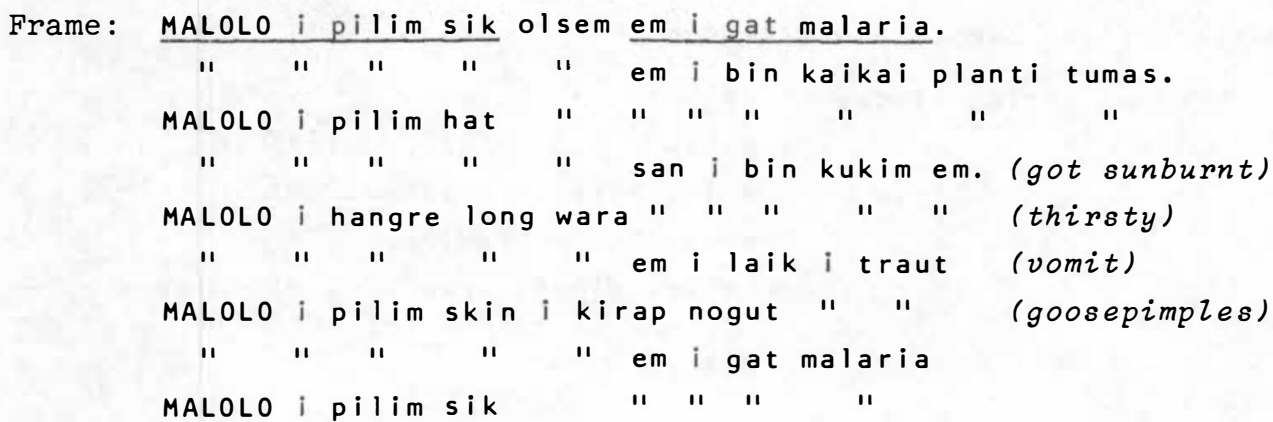

\subsection{ANSWERING NEGATIVE QUESTIONS}

Negative questions are questions which contain a negative, e.g., Em i no go a? Didn't he go? In that respect they present no particular difficulty for English speakers. Where the difficulty comes is in answering them because for English speakers the answers always seem to be the reverse of what one expects them to be.l Thus, for example, if a Pidgin speaker were answering the above question he would answer Nogat if he meant that the person referred to did go, and yes if he meant that the person referred to did not go. However, despite its rather bewildering initial impact the system behind this answering scheme is quite simple and regular. All the Pidgin speaker is doing is agreeing or disagreeing with what is asked in the negative question (just as for positive ones). That is, by answering nogat the Pidgin speaker is really saying What you say is untrue and by answering yes he is saying what you say is true. Compare the following:
Q: Em i no go a?
Didn't he go?
A: Yes, em i no go.
No, he didn't! (= What you say is true,
A: Nogat, em i go (pinis). Yes, he went. (= What you say is
Q: Yu no traut a?
A: Yes, mi no traut.
You didn't vomit eh?
No, I didn't. (= What you say is true,
A: Nogat, mi traut.
Yes, I vomited. (= What you say is untrue, I did vomit.)

Practice Drills

Exercise 1: Answer all of the following negative questions in the affirmative. That is, you show that you agree with what the questioner says in them by beginning your answer with yes and repeating the sentence underlying his questilon. Ready?

1. 01 i no save tok pisin a?

(pause)

$$
\text { Yes, ol i no save tok pisin. }
$$

${ }^{1}$ Another difficulty is that many educated speakers now answer these questions in an English way thereby making the whole system confusing. 
2. Dispela man i no kam asde a?

(pause)

Yes, dispela man i no kam asde.

3. Bai ol i no bekim pas a?

(pause)

Yes, bai ol i no bekim pas.

4. Yu no save pasin bilong draivim ka a?

(pause)

Yes, mi no save pasin bilong draivim ka.

5. Yupela i no bin sindaun nating a?

(pause)

Yes, mipela i no bin sindaun nating.

Exercise 2: Now answer the same questions in the negative. That is, you show that you disagree with what the questioner says in them by beginning your answer with nogat and repeating the sentence underlying his question without the negative no. Ready?

1. 01 i no save tok pisin a?

(pause)

Nogat, ol i save tok pisin.

2. Dispela man i no kam asde a?

(pause)

Nogat, dispela man i kam asde.

3. Bai ol i no bekim pas a?

(pause)

Nogat, bai ol i bekim pas.

4. Yu no save pasin bilong draivim ka a?

(pause)

Nogat, mi save pasin bilong draivim ka.

5. Yupela i no bin sindaun nating a?

(pause)

Nogat, mipela i bin sindaun nating.

Exercise 3: Now answer the following questions affirmatively or negatively as indicated by the cue word given by the instructor. Ready?

1. Yu no doktaboi a?

(yesa)

(pause)

Yesa, mi no doktaboi.

2. Emtripela i no laik i peim takis a? (nogat) (pause)

Nogat, emtripela i laik i peim takis.

3. Pren bilong mi i no kamap yet a? (yesa) (pause)

Yesa, pren bilong yu i no kamap yet.

4. 01 i no inap lainim tokples a?

$($ nogat $) \quad($ pause $)$

Nogat, ol i inap lainim tokples.

5. Kaikai bilong yu i no hat a?

(nogat) (pause)

Nogat, kaikai bilong mi i hat.

$I_{\text {peim }}$ takis $=$ pay tax. 
Evaluation Exercises

Exercise 1: Pretend that you are visiting Madang for the first time from Port Moresby and that you are talking to a local resident. Give appropriate answers to the resident's questions. Ready?

R: Nau tasol i nambawan taim yu kam long Madang a?

A: Yes, nau tasol i nambawan taim mi kam long Madang.

R: Yu no kam longen bipo a?

A: Yes, mi no kam longen bipo.

R: Tasol yu stap we na yu kam?

A: Mi stap long Mosbi na mi kam.

R: Oloman, yu stap long Mosbi na yu no kam long Madang bipo a?

A: Yes, mi stap long Mosbi na mi no kam long Madang bipo.

R: Bai yu go bek long Mosbi gen o nogat?

A: Yes, bai mi go bek long Mosbi gen.

R: Orait, apinun masta.

A: Apinun, wantok.

Exercise 2: Show that you understand what the Pidgin answers yes or nogat to the following questions mean by giving a full reply in English. Ready?

1. Kapul i no olsem dok a? Yesa!

Answer: No, a possum is not the same as a dog.

2. Ples bilong yu $i$ no pulap long ol meri a? Nogat!

Answer: Yes, my village is overflowing or overcrowed with women.

3. Planti de $i$ go pinis na ol $i$ no bung yet a? Yesa!

Answer: No, it's a long time and they still haven't gathered together.

4. Ating hangre bilong $m i$ olsem hangre bilong yu a? Yesa!

Answer: Yes, you're probably as hungry as 1 am.

5. Yu no hatwok tru long painim kaikai a? Nogat!

Answer: Yes, I'm working very hard looking for food.

11.2 MAS + V: Obligation

Verbs preceded by mas ${ }^{l}$ in Pidgin indicate actions which the actor is obliged to carry out, e.g.,

01 i mas lukautim papamama bilong ol.

Yu mas rausim olgeta pipia i stap nabaut long dispela ples hia.
They must/should look after their parents.

You must/should get rid of all the rubbish around about here.

Ior mas $i$ for some speakers. 
The usage is similar to that of English must except that the negative versions in Pidgin are weaker than those in English and mean should not or it is not necessary (for someone to do something) rather than must not. This latter sense, that is, one of outright prohibition, is expressed in Pidgin by using the negative imperative no ken already introduced in Section 7.2 above.

Practice Drills

\section{Exercise 1: Simple Substitution}

Frame: Tude em i mas ainim klos bilong mi.

$$
\text { ( } k \text { linim, samapim, bilasim, redi im, ainim) }
$$

Exercise 2: Negate the following sentences by inserting no into them in the correct place:

1. 01 manmeri bilong dispela ples i (no) mas wok long gavman.

(pause)

2. Sapos yu laikim man i kam hariap yu (no) mas bikmausim em.

3. Taim em i go yumi i (no) mas go wantaim em.

4. Olgeta $i$ (no) mas agens long kaunsil.

5. Sapos em i apim prais bilong kopi mipela i (no) mas lus im em.

Exercise 3: Now change the negative sentences you have just given into ones indicating outright prohibition by substituting no ken for no mas.

1. 01 manmeri bilong dispela ples $i$ no mas wok long gavman.

ol manmeri bilong dispela ples $i$ no ken wok long gavman.

2. Sapos yu laikim man i kam hariap yu no mas bikmausim e m.

(pause)

Sapos yu laikim man i kam hariap yu no ken bikmausim em.

3. Taim em i go yumi i no mas go wantaim em.

(pause)

Taim em i go yumi i no ken go wantaim em.

4. 0lgeta i no mas agens long kaunsil.

(pause)

olgeta i no ken agens long kaunsil.

5. Sapos em i apim prais bilong kopi mipela i no mas lusim em.

(pause)

Sapos em i apim prais bilong kopi mipela i no ken lusim em.

\section{Evaluation Exercises}

Exercise 1: Say what the following sentences mean in English:

1. Mipela i mas sanapim wanpela nupela haus tambaran. (pause)

We (excl.) should/must erect a new spirit house. 
2. Long taim bilong wok yupela no ken ritim "Wantok".

(pause)

You (pl.) must not read Wantok during working hours.

3. Olgeta i mas redi long pilai stret long taim wok i pinis.

(pause)

Everyone must be ready to play as soon as work is finished.

4. Em i mas rabim het bilongen isi isi.

(pause)

He/she must/should rub his/her head carefully.

5. Bihain long taim mi pasim stua yu mas kirap hatim kopra.

(pause)

After I shut the store you should/must begin to heat the copra.

Exercise 2: How would you say the following things in Pidgin?

1. When you go into the church you must not talk!

(pause)

Taim yu go insait long haus lotu yu no $\left\{\begin{array}{c}k e n \\ m a s\end{array}\right\}$ toktok.

2. If it rains we and you must cover up the copra.

(pause)

Sapos ren i pundaun yumi i mas karamapim kopra.

3. They must not chew betel-nut in my house.

(pause)

01 i no ken kaikai buai insait long haus bilong mi.

4. Should you and I address the envelope for her or not? (pause)

Yumitupela i mas adresim skin pas bilongen o nogat?

5. You must not burn the grass. Understand?

(pause)

Yu no ken kukim kunai. Save?

\subsection{REFLEXIUE PERSONAL PRONOUNS}

When the subject and the object (or indirect object in the case of verbs like givim, soim etc.) are the same the object (or indirect object) is expressed by the corresponding pronoun plus yet. E.g.,

Mi paitim mi yet.

I hit myse $\mathrm{f}$.

Dispela dok i kilim i dai em yet.

This dog killed itself.

Yupela i no lukim yupela yet a?
Didn't you (pl.) see yourselves?

You should have no difficulty recognising these as parallelling the English self forms. However, be careful not to confuse them with the emphatic forms given in Section 8.2 above which are of the same form. Consider, for example:

Mi paitim mi yet.

I hit mysezf.

Mi yet i paitim em. \{I hit him myself. (1.e. I was the one who hit Mi yet mi paitim em. 'I hit him. him, not someone else.)

Mi patim het bilong mi yet.

I hit my own head. 
Practice Drills

Exercise 1: Simple Substitution

Frame: Nogut yu katim yu yet.

(sutim, kilim i dai, bagarapim ${ }^{1}$, kukim, katim)

\section{Exercise 2: Simple Substitution}

Frame: Mi yet i skelim rais.

(raitim nem bilong mi, go long 0strelya, bringim kago

i kam, haitim hanwas, skelim rais)

Exercise 3: Change the pronouns in the following frame to those given as cue:

Frame: Em i brukim han bilong em yet.

(mi, ol, yu, mipela, em)

Exercise 4: Change the objects or indirect objects in the following sentences into reflexive pronouns:

1. Asde sutboi i sutim sutboi long masket.

(pause)

Asde sutboi i sutim em yet long masket.

2. 01 doktaboi i ken glasim ol doktaboi.

(pause)

01 doktaboi i ken glasim ol yet.

3. Masalai i save tanim masalai long man o diwai samting. (pause)

Masalai i save tanim em yet long man o diwai samting.

4. Mi skulim mi long tok pisin.

(pause)

Mi skulim mi yet long tok pisin.

5. Taim mi wok long rot mi lukim wanpela dok i klinim wanpela dok.

(pause)

Taim mi wok long rot mi lukim wanpela dok i klinimem yet.

\section{Evaluation Exercise}

Say what the following sentences mean in English.

1. Dispela stuakipa hia em yet i opim stua.

(pause)

This storekeeper opened the store himself.

2. Yu sindaun long ples bilong yu yet! Yu no ken wokabaut nating long rum!

Sit down in your own place. You mustn't walk around aimlessly in the room.

$\overline{I_{\text {bagarapim }}}=$ hurt, do damage to, ruin. 
3. Kiap i tok, "Olgeta kanaka i mas lukautim ol yet; gavman i no inap mekim olsem moa."

The Government officer said, "All the natives must take care of themselves; the government is not able to do it any more."

4. Husat i ken raitim nem bilong em yet?

(pause)

Who can write their own name?

5. Taim mi stap long ami mi yet mi kisim save bilong draivim ka.

When I was in the army I learned how to drive a car myself.

11.4 OLSEM + Clause: as, just like, as if, as though ${ }^{1}$

01 sem Joining clauses in Pidgin covers a variety of senses in English depending on the meanings expressed in the two clauses so conjoined. Consider, for example,

01 i save wokim haus olsem papa bilong ol i bin soim em.

MALOLO i pilim sik olsem em i gat malaria.

Em i paitim het bilong mi olsem em i longlong.

Mi lainim tok Pisin olsem baimbai mi inap toktok wantaim ol kanaka.

If olsem precedes both clauses it expresses the idea of just as...so (then)... . For example,

olsem ol masta i save kaikai olsem Just as Europeans eat so too yupela i mas kaikai tu.

\section{Practice Drills}

\section{Exercise 1: Simple Substitution}

Frame: 01 i save wokim haus olsem papa bilong ol i bin soim em. (taitim banara, bilasim bilum, laitim paia, bekim tok, wokim haus)

\section{Exercise 2: Progressive Substitution}

Frame: Mi lainim tok Pisin olsem baimbai mi inap toktok wantaim ol kanaka.

$\begin{array}{llllllllll}\text { Mi go long Niu Gini } & \text { " } & \text { " } & \text { " } & \text { " } & \text { " } & \text { " } \\ \text { " " } & \text { " } & \text { " } & \text { olsem baimbai mi ken kisim save Iongen. }\end{array}$

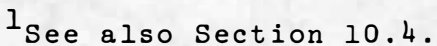




\section{$\frac{\text { Mi ritim baibel }}{\text { " }}$ olsem baimbai mi ken kisim save longen. "olsem baimbai mi klia long mining bilongen. Mi lainim tok Pisin" " " " " " " " "baimbai mi inap toktok wantaim ol kanaka.}

Exercise 3: In this exercise you have to substitute the Pidgin words given as cues for the words kaikai in the following frame :

olsem ol masta i save kaikai, olsem yupela i mas kaikai tu.

For example, if the instructor gives the cue toktok your answer should be:

olsem ol masta $i$ save toktok, olsem yupela i mas toktok $\mathrm{tu}$.

Ready? Here is the frame again:

01 sem ol masta i save kaikai, olsem yupela i mas kaikai tu.

Here are the cues:

1. waswas

Answer: 01 sem ol masta i save waswas, olsem yupela i mas waswas tu.

2. klinim sua

Answer: 01 sem ol masta i save klinim sua, olsem yupela i mas klinim sua tu.

3. draivim ka

Answer: 0lsem ol masta i save draivim ka, olsem yupela i mas draivim ka tu.

4. givim sut

Answer: 01 sem ol masta i save givim sut, olsem yupela i mas givim sut tu.

5. sekan long praim minista

Answer: 01 sem ol masta i save sekan long praim minista, olsem yupela i mas sekan long praim minista tu.

\section{Evaluation Exercise}

Join the following pairs of sentences together using olsem or olsem...olsem as indicated in the cues given after each pair and then say what your answer means in English. For example, the instructor will give two sentences like this:

6a. Mi go long skul.

6b. Baimbai mi ken kisim save.

$I_{\text {mining }}=$ meaning . 
and say the cue olsem. Your answer should then be:

Mi go long skul olsem baimbai mi ken kisim save. That is,

I am going to school so that I can get or gain knowledge.

Ready?

1a. Pisin i pundaun.

lb. Han bilongen i bruk.

Cue: olsem

Answer: Pisin i pundaun olsem han bilongen i bruk. That is, The bird fell down as if its wing were broken.

2a. Mama bilong yu i skulim yu.

2b. Yu mas skulim pikinini bilong yu tu.

Cue: olsem...olsem

Answer: Olsem mama bilong yu i skulim yu olsem yu mas skulim pikinini bilong yu tu. That is, Just as your mother taught you so you must teach your child too.

3a. Susa bilong mi i go bek long ples.

3b. Baimbai em i ken lukautim papamama bilong mipela.

Cue : olsem

Answer: Susa bilong mi $i$ go bek long ples olsem baimbai em $i$ ken lukautim papamama bilong mipela. That is, My sister went back home so that she can look after our parents.

4a. Sampela i pilai kikbal strong tumas.

4b. 01 i laik i kilim i dai olgeta arapela.

Cue: olsem

Answer: Sampela i pilai kikbal strong tumas olsem ol i laik i kilim i dai olgeta arapela. That is, Some play football very hard as if they want to kill everybody else.

5a. San i save kamap olgeta de.

$5 b$. Mun tu i save kamap olgeta nait.

Cue: olsem...olsem

Answer: 0lsem san i save kamap olgeta de olsem mun tu i save kamap olgeta nait. That is, Just as the sun comes up every day so then the moon comes up every night.

\section{TEXT}

Listen to the following text and then see how much of it you can transcribe and translate. It is spoken by Simon Wik of Musingwik village, East Sepik District. Here is the text:

Ah, pastaim tru long mi go het long stori nem bilong mi simon Wik, bilong ples Musingwik, insait long Dreikikir Patrol Pos, Is Sepik. Long namba naintin de long mun Novemba yia 1972 mi yet mi bin ah-- 
rong long--mi klaimap ${ }^{l}$ long mango na mi--mi bin pundaun. Taim mi pinisim olgeta samting long bus long kirapim wanpela haus bilong mi mi bin wokabaut kam antap, na tu meri bilong mi em i bin sindaun. Na mi yet mi go antap long mango. Mi go antap. Planti mango mi bin kisim, kam daun long graun nau, wanpela em i bikpela moa. Na mi laik traim long kalap i go na holim dispela mango han bilong mango i bin bruk. Wanpela mi bin putim lek longen na narapela tu long han, wanpela i bin bruk daunbilo na narapela i bin lus antap tu, mi kamdaun i kam i go mi bamim as bilong mi long graun. Na klostu mi bin kisim bagarap ${ }^{2}$, tasol planti man moa ol i bin i kam na holimmi, na ol i askim mi, "olsem wanem, yu kisim bagarap?" Tasol mi yet mi tok, "Nogat, mi no kisim bagarap." 01 i kisim mi stret, kam daun, putimmi insait long veranda bilong mi yet, na mi slip inap, ol i salim tok long kar ${ }^{3}$ bilong Tumam, P.M.V., em i kam na tekim ${ }^{4}$ mi long hia i go long haus sik. Insait long hospitel ${ }^{5} \mathrm{mi}$ slip inap long tu en hap wiks, long Dreikikir haus sik. Taim mi pinis long haus sik, mi bin i kam long hia, em olsem baksait bilong mi tu, mi no pilimorait. Em i nogut i stap yet. Mi wokabaut liklik tasol, mi slip, i go inap nau ating em $i$ wok long kamap i orait liklik liklik nau. Na nau mi sindaun na mi pilim olsem, ating baimbai ${ }^{6}$ em $i$ pinis long samting olsem tripela wik o fopela wik samting bai mi pinis long dispela as bilong mi long mi bin bamim long graun. Em tasol, stori bilong mango mi bin pundaun longen em mi stori long yupela.

\section{[Playing time: 2 minutes]}

\section{ENGLISH TRANSLATION :}

Ah, first of all before I go ahead with my story my name is Simon Wik, from Musingwik village, in the Dreikikir Patrol Post (area), East Sepik (District). On the 19th November, 1972, I was--had an accident with--I climbed up a mango tree and I--I fell down. When I had finished doing all the things in the bush associated with building my

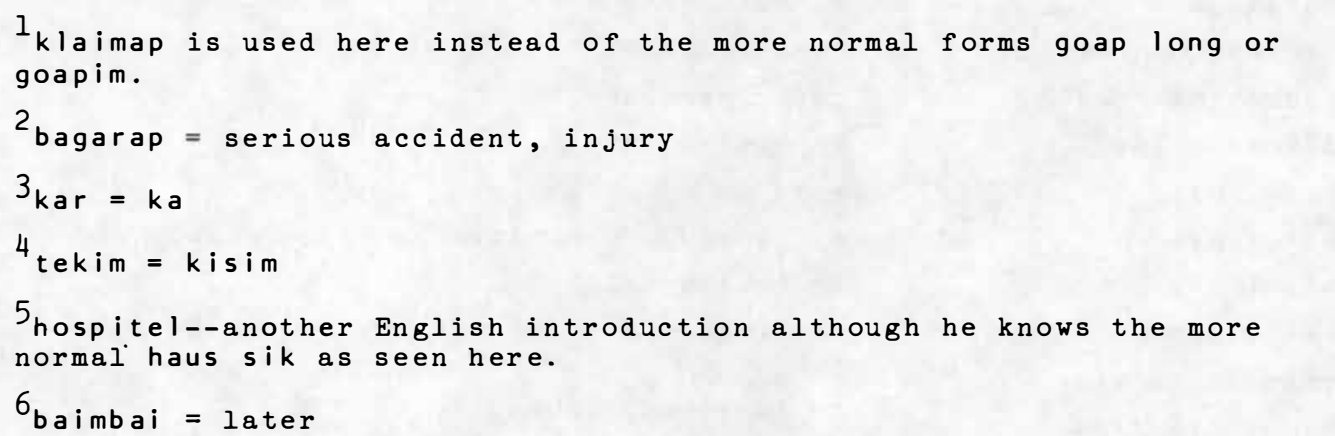


house I walked back (up here to Musingwik) and (also) my wife was sitting down. But I (emphasis) went up the mango tree. I went up. I got plenty of mangoes (but while) I was coming down (lit. coming down to the ground then) ( $I$ saw) a very very big one and I wanted tol was just going to snatch it (lit. leap and hold this mango) when the branch of the tree broke--one that I had my foot on and another that I was holding on to (lit. another too in the hand). The one underneath broke and the other gave way up above too and I fell down and bumped my tail on the ground. I was very nearly seriously injured, but a lot of men came and picked me up and asked, "Why? Did you get hurt very badly?" But I (emphasis) said, "No, I'm not seriously injured." (So) they brought me down straight away and put me on my very own verandah and I lay there until they sent word for the Tumam truck, the P.M.V. truck, (to come) and it came and took me from here to the hospital. There (lit. in the hospital) I lay for two and a half weeks, in the Dreikikir hospital. When I left the hospital I came back here but my back was not feeling the best. It's still not right. Up till now I've been walking around only a little and lying down and it seems to be improving slightly llit. I walk around only a little bit, I lie down, and so on up till now perhaps it is busy becoming better a very little bit now). Now I sit and I feel like this --probably in about three or four weeks it will be all over, this tail trouble where I bumped it on the ground. That's all there is to this story I've been telling you about falling out of the mango tree.

Now to end this unit here is a recording of a conch shell trumpet or taur in Pidgin which is used to signal the return of the Siassi trading fleet from the sio coast. This recording comes from Sheridan (1958: side 2, track 2, 1tem a).

\section{SUPPLEMENTARY VOCABULARY}

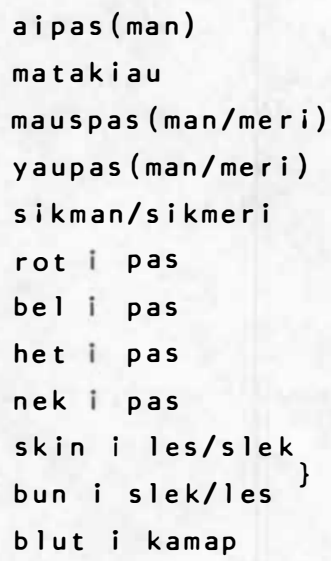

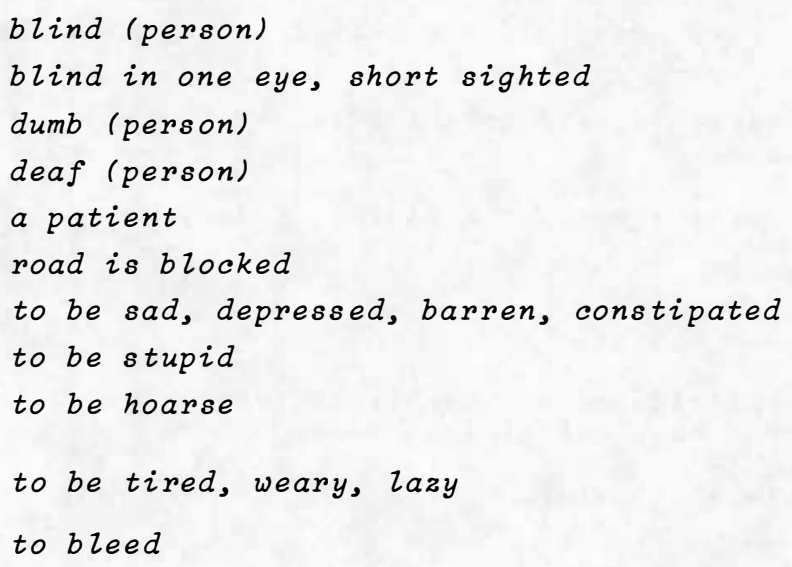




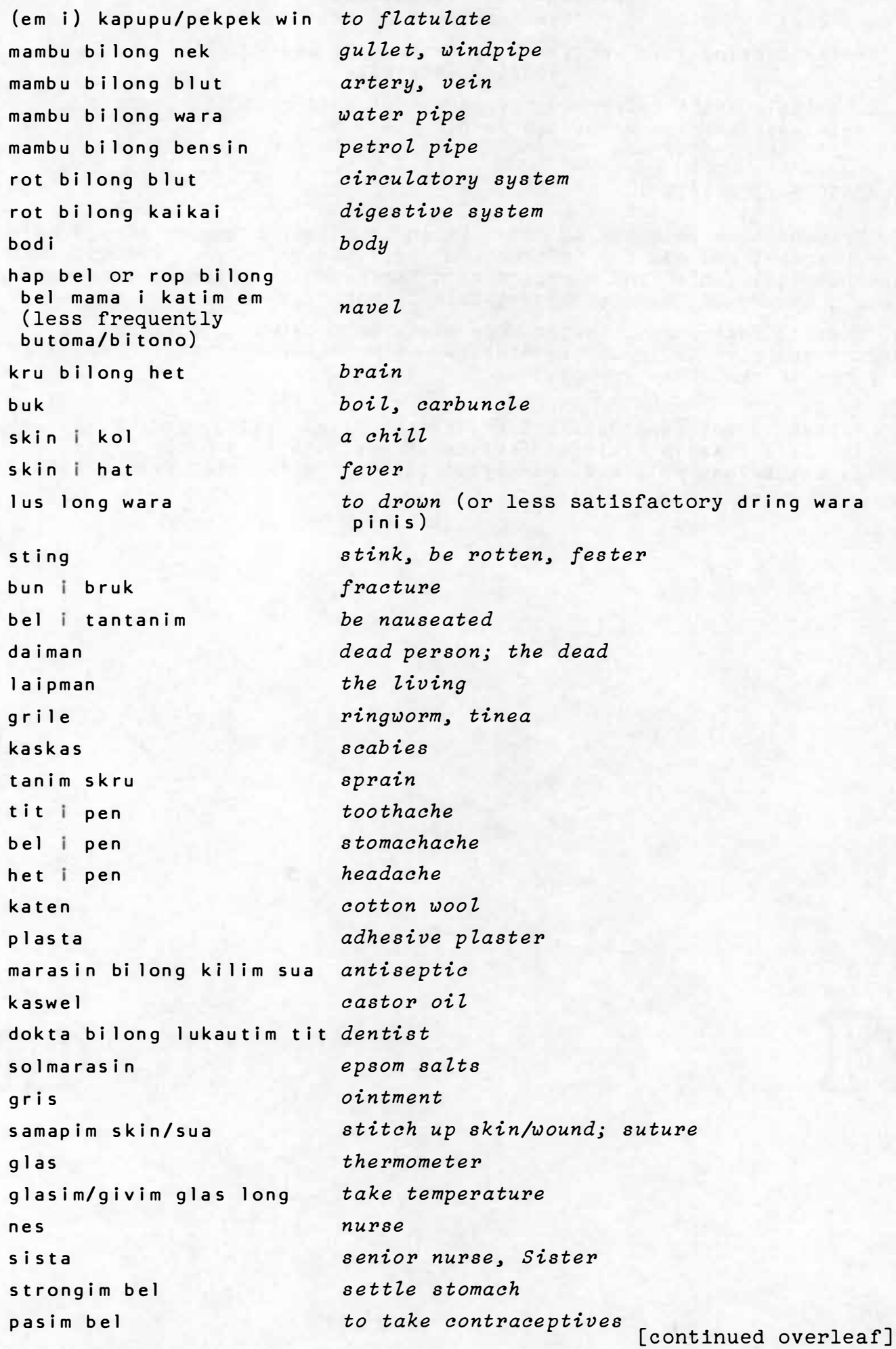




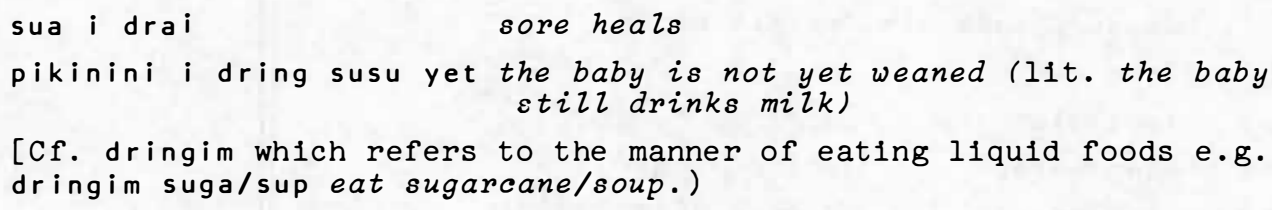

\section{CLASSROOM EXERCISES}

1. Pretend some relative of yours is in hospital. Ring up (or go to) the hospital and ask for information about the relative. Pretend that the hospital can't find a record card for him/her. Discuss the case (e.g., nature of illness/injury, date of entry, ward etc.).

2. Picture Talk. Have two or more pictures related to sickness or injury and give to groups to discuss. Then one spokesman for each reports to the other groups.

3. Read:

1. Kobu i Wok Long Daunim Sik (Kristen Press, 1971); and/or

11. Ibala i Karim Pikinini (Kristen Press, 1967); and/or

111. Buk Bilong Helpim 01 Manmeri i Daunim Sik (Kristen Press, 1967). 


\section{UNIT 12}

CONVERSATI ON

\section{Long Haus Masta}

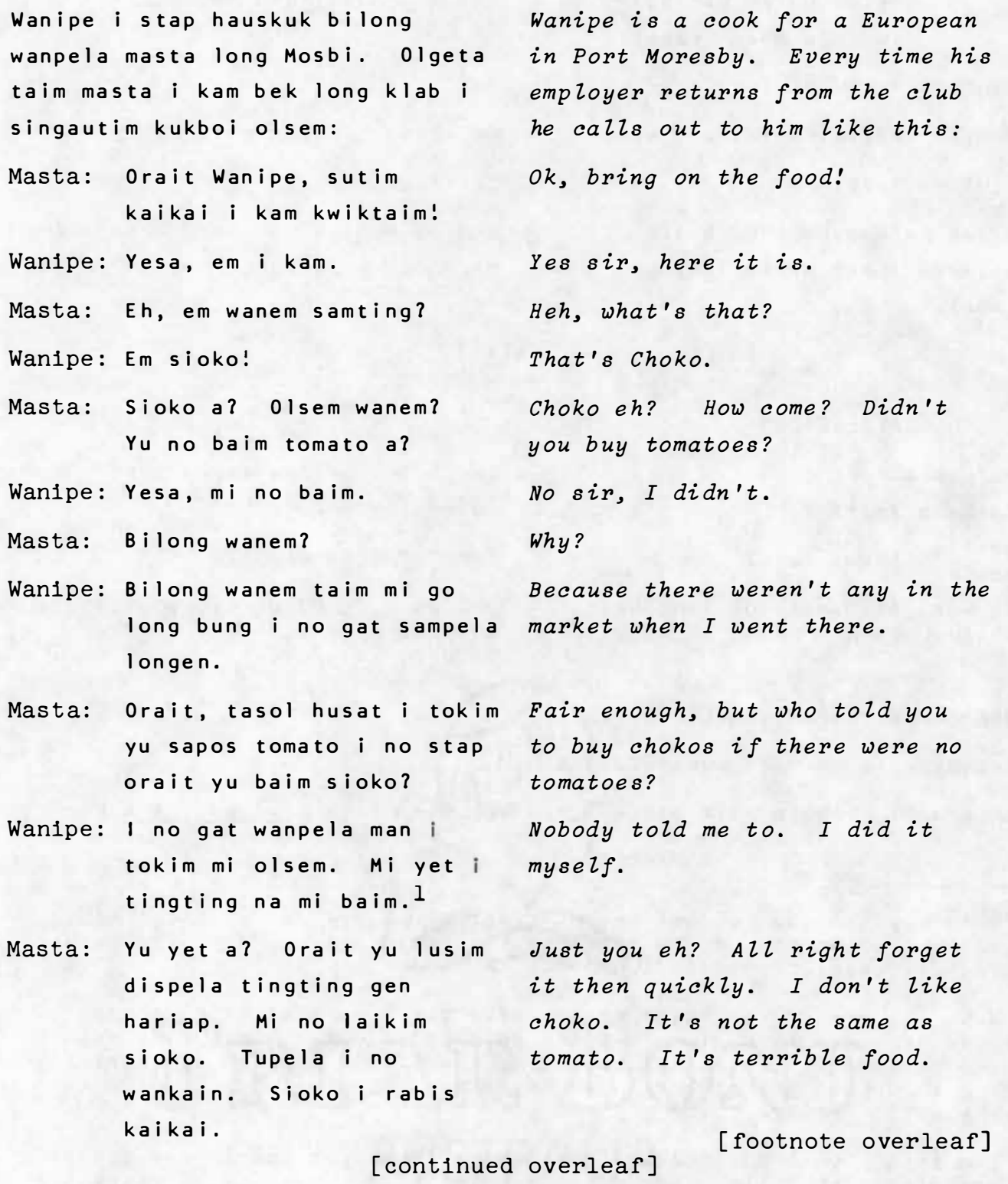


Wanipe: Wanem? Bai mi rausim 01 ?

Masta: Maski, larim em i stap. Tasol yu no ken baim sampela moa. Save?

Wanipe: Yesa, mi save.

Masta: Orait, kolwara i kam! ${ }^{2}$

Wanipe: Yesa.

Olsem na Wanipe i go kisim

kolwara i kam putim long

tebol.
What then, should I throw them out?

No, leave them there. But don't buy any more, understand?

Yes.

ok, bring in the cold water.

Yes sir.

And so Wanipe goes and brings in the cold water and puts it on the table.

$\left[\right.$ Musik ${ }^{3}$ ]

\section{USEFUL EXPRESSIONS}

Yu pamim lam.

Kamapim lait !

Swisim ${ }^{4}$ indai lait!

Mi wok kalabus tasol long haus mas ta.
Pump the (pressure) Zantern!

Switch on the light!

Turn off the Zight!

I work very hard (1.e., without

a spell or let up) at the

European's house.

\section{VOCABULARY EXPANSION EXERCISES}

\section{Exercise 1: Simple Substitution}

Frame: Olgeta taim masta i kam bek long klab i singautim kukboi olsem.

pretim (frighten)

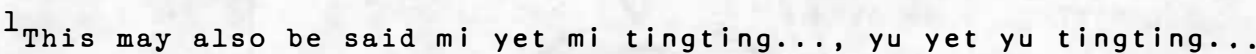
etc. where the pronoun is repeated instead of the predicative marker. Cf. Section 8.2 footnote 1 .

${ }^{2}$ Note the use of the third person here for a command which corresponds roughly to English Let the cold water come. This form can also be used in the plural too. For example, a command to carriers to pick up the patrol boxes and begin the patrol is orait, ol i wokabaut! i.e. You ( $p$ l.) get going!

3 The traditioral music heard throughout this unit comes from the Buin area of Bougainville. The first one is called Homa and is feast ritual music played on a three note panpipe, paigam pitsi, when the food gatherers bring in the harvest. The second is Pempang, another piece of music from the food gathering ritual but this time played on a four note penpipe, korigam pitsi. Both pieces come from Sheridan (1958: side 2, track 7, items b and c respectively).

${ }^{4}$ Also said as switim. 


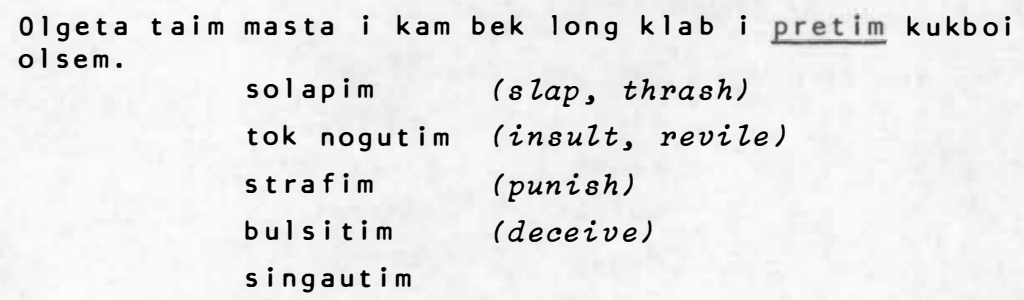

Exercise 2: Simple Substitution

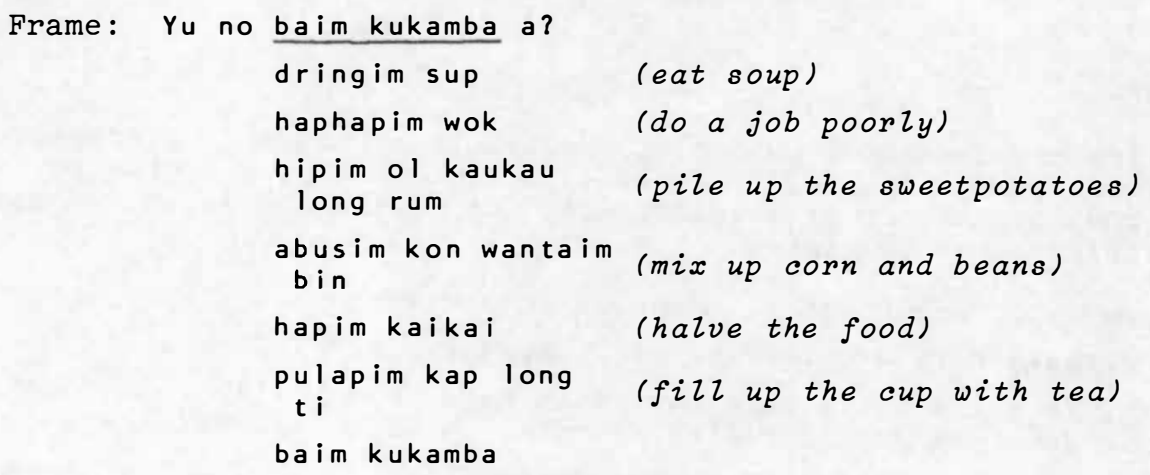

Exercise 3: Simple Substitution

Frame: Maski, larim em i stap. pulapim kap long $\mathbf{t} \mathbf{i}$

st ap

Exercise 4: Simple Substitution

Frame: Kolwara i kam!

Kop i

Mas is

$\mathrm{T}$ i

Muliwara

Kolwara

\footnotetext{
$I_{k i r a p}$ nogut is also used for to be surprised, e.g., Tisa i kirap nogut long ol tokbek bilong ol sumatin the teacher was surprised by the pupils' answers.
} 


\section{Exercise 5: Simple Substitution}

\begin{tabular}{|c|c|c|c|}
\hline \multirow[t]{8}{*}{ Frame: } & \multirow{8}{*}{ Wanipe i stap } & hauskuk & \multirow[t]{2}{*}{ Iong Mosbi. } \\
\hline & & tisa & \\
\hline & & kamda & (carpenter) \\
\hline & & kuskus & (clerk) \\
\hline & & fama & (farmer) \\
\hline & & plisman & (policeman) \\
\hline & & kiap & (patrol officer) \\
\hline & & hauskuk & \\
\hline
\end{tabular}

\subsection{WANKAIN same}

In Pidgin there are a number of constructions based on different uses of the word kain kind of, sort of which are very useful even though they present no great difficulty for English speakers. These are divisible into two types:

(1) those which occur before nouns as adjectives, e.g.,

a. dispela kain $N$ this kind of $N$, such $N s$, Ns of this sort

e.g., Yu gat dispela kain mani long Papua Niu Gini? Have you got this kind of money in Papua New Guinea?

b. wanem kain $\mathrm{N}$ which kind/sort of $N$ ?

e.g., Yu gat wanem kain mani long Papua Niu Gini? What kind of money have you got in Papua New Guinea?

c. planti kain $\mathrm{N}$ many kinds of $N$, plenty of kinds of $N$

e.g., Mipela i gat planti kain mani long Papua Niu Gini. We have many kinds of money in Papua New Guinea.

d. kainkain $\mathrm{N}$ various kinds of $N$, all sorts of $N$

e.g., Mipela i gat (olgeta) kainkain mani long Papua Niu Gini. We have (all) different kinds of money in Papua New Guinea.

Note in these that dispela kain $\mathbf{N}$ is often shortened to diskain $\mathrm{N}$ or may alternatively be expressed as kain $\mathrm{N}$ olsem, e.g.,

Yu no ken mekim kain tok olsem!

Don't say that kind of thing or Don't say that!

(2) those which occur after the predicative marker $i$ as predicates or verbless sentences, to express the idea of same or different e.g.,

a. wankain same

e.g., Tupela koki i wankain.

The two parrots are the same (the one kind).

Tupela koki i wankain liklik.

The two parrots are similar.

Tupela koki i no wankain tumas.

The two parrots are not very similar.

sik bilong ol i wankain.

They all have the same disease.

Note that the Pidgin sentence is often "turned around" compared with English, and that the use of wankain is different from the use of olsem and wanpela kain, e.g., 
Dispela koki i olsem dispela (koki).

These two parrots are alike/same.

Mipela i gat wanpela kain mani long Papua Niu Gini tasol. We've got only one kind of money in Papua New Guinea.

b. arakain different

e.g., Dispela tupela koki i no wankain; dispela hia i arakain. These two parrots are not the same; this one is different.

Practice Drills

Exercise 1: Simple Substitution

Frame: Mipela i gat dispela kain mani long Papua Niu Gini.

(planti kain, kainkain, olgeta kain, wanpela kain, dispela kain)

\section{Exercise 2: Simple Substitution}

Frame: Tupela koki i wankain.

(sik bilong ol, olgeta kanaka bilong Papua Niu Gini, ol dispela supia, tokples bilong olgeta hap, tupela kok i)

Exercise 3: Give answers to the following questions using the Pidgin cues provided:

1. Papua Niu Gini i gat wanem kain abus i stap insait long bus bilongen?

(kainkain) (pause)

Papua Niu Gini i gat kainkain abus i stap insait

long bus bilongen?

2. Husat i givim yupela dispela kain mani?

(wantok bilong mi) (pause)

Wantok bilong mi i givimmipela dispela kain mani.

3. 01 i smokim wanem kain brus long 0strelya?

(tupela kain) (pause)

01 i smokim tupela kain brus long Ostrelya?

4. Asde ol i lukim planti kain pis long wara o nogat?

(yes) (pause)

Yes, asde ol i lukim planti kain pis long wara.

5. Bai mi kisim ol dispela kain ston we? (long graun) (pause)

Bai yu kisimol dispela kain ston long graun.

Exercise 4: Answer the following questions using the cues provided. If the cue is no add the explanation dispela hia i arakain at the end. For example, if the question was: Dispela tupela koki i wankain o nogat? and the cue given was yes then your answer should be Yes, dispela tupela koki $i$ wankain; on the other hand if the cue 
were nogat then your answer should be Nogat, dispela tupela koki i no wankain; dispela hia i arakain. Ready?

1. Yu painim pinis tupela hanwas i wankain a? (yes) (pause) Yes, mi painim pinis tupela hanwas i wankain.

2. 01 dispela taro i wankain o nogat? (nogat) (pause) Nogat, ol dispela taro i no wankain; dispela hia i arakain.

3. Dispela sik bilong ol i wankain em i kamap we?

$$
\text { (long Saina) (pause) }
$$

Dispela sik bilong ol $i$ wankain em $i$ kamap long Saina.

4. Mani bilong Ostrelya na mani bilong Papua Niu Gini i olsem wanem--tupela i wankain o wanem?

(yes) (pause)

Yes, mani bilong ostrelya na mani bilong Papua

Niu Gini i wankain.

5. Olgeta su bilong yu i wankain liklik o nogat? (nogat) (pause)

Nogat, olgeta su bilong mi i no wankain liklik;

dispela hia i arakain.

\section{Evaluation Exercise}

How would you say the following things in Pidgin?

1. We all have the same kinds of houses.

(pause)

01 haus bilong yumi olgeta $i$ wankain.

2. The Zanguages of Papua New Guinea are not all the same; some are like ours and some are different.

(pause)

olgeta tokples bilong Papua Niu Gini i no wankain--

sampela $i$ olsem tokples bilong yumi; sampela i arakain.

3. What kind of a bird will you shoot?

(pause)

Bai yu sutim wanem kain pisin?

4. There are all different kinds of fish in the sea.

(pause)

l gat olgeta kainkain pis long solwara.

5. Don't say that kind of thing!

(pause)

Yu no ken mekim kain tok olsem!

Yu no ken mekim dispela kain tok!

Maski mekim kain tok olsem!

\subsection{NO GAT WANPELA: Nobody, No one, Nothing}

There is no single word in Pidgin corresponding to nobody, nothing, no one etc. In English. However, the same idea is expressed in Pidgin by using the negative form of $i$ gat there is, there are introduced in Unit 10, e.g.,

Husat i stap? I no gat wanpela i stap.
Who's there? There is no one (there). 


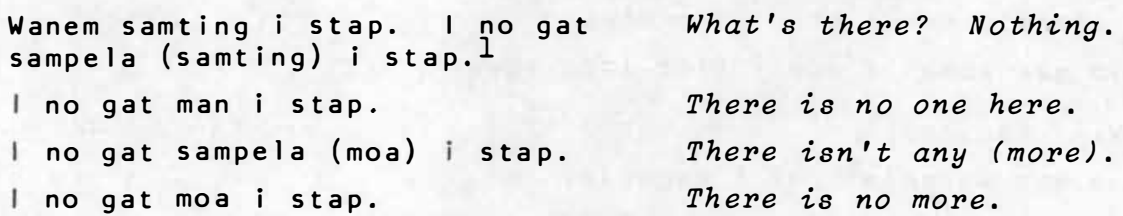

English speakers should be particularly careful of using nating as an equivalent of nothing etc. in Pidgin.2 E.g.,

Mi no gat wanpela samting.

$\approx M i$ gat nating.
I haven't got anything.

*I haven't got anything.

Note also that no gat is not the same as nogat no.

\section{Practice Drills}

Exercise 1: Answer the following questions using the cues provided. In each case your answer should begin with i no gat. For example, if the question were Husat $i$ stap? and the cue was wanpela your answer should be 1 no gat wanpela i stap. Ready?

1. Haumas kaukau i stap? (planti moa) (pause) I no gat planti moa i stap.

2. Husat i kirap nogut? (wanpela) (pause) I no gat wanpela i kirap nogut.

3. I gat sampela meri i kam tu? (nogat) (pause)

Nogat, i no gat sampela meri i kam tu.

4. Wanem samting i sanap long hap? (wanpela samting) (pause)

I no gat wanpela samting i sanap long hap.

5. Husat i dringim sup asde? (wanpela) (pause)

I no gat wanpela i dringim sup asde.

Exercise 2: Change the subjects in the following sentences into ones indicating that no one, nobody, or nothing performed the actions described. Each answer will be based on the structure $i$ no gat but you will have to vary the objects to suit the particular sentences. For example, if the given sentence were Mipela i gat planti pik your answer should be 1 no gat wanpela bilong mipela $i$ gat planti pik (lit. There is not one of us who has plenty of pigs).

1. Dispela pikinini i save mumutim kaikai.

(pause)

I no gat wanpela pikinini i save mumutim kaikai.

\footnotetext{
${ }^{1}$ often these answers will be heard without the predicative marker i, e.g., No gat wanpela.

${ }^{2}$ Cf. Section 2.3 where it was indicated that nating or not is generally used in the classroom for nought or zero, and Unit 6, Vocabulary Expansion Exercise 3, where nating = for no reason, in vain etc.
} 
2. I gat sampela moa $i$ stap long stua.

(pause)

I no gat sampela moa i stap long stua.

3. 01 trak i bagarap.

(pause)

I no gat wanpela trak i bagarap.

4. Olgeta wokboi i pinisim wok o nogat?

(pause)

Nogat, i no gat wanpela wokboi i pinisim wok.

5. Mipela i gat planti pik.

(pause)

I no gat wanpela bilong mipela i gat planti pik.

\section{Evaluation Exercise}

How would you say the following things in Pidgin?

1. There's no milk left!

(pause)

I no gat sampela susu i stap.

2. I am sitting down doing nothing.

(pause)

Mi sindaun nating.

3. I saw nothing, or I didn't see anything.

(pause)

Mi no lukim wanpela samting.

4. Q: Where is the plate?

A: There isn't any.

(pause)

Q: Plet i stap we?

A: I no gat wanpela i stap.

5. Q: OZd man, is there anyone in this village?

A: They're all gone to the garden.

(pause)

Q: Lapun, i gat sampela man i stap long ples hia?

A: Nogat, i no gat wanpela. olgeta i go pinis long gaden.

\subsection{COMPARISON OF ADJECTIVES AND ADVERBS}

In Section 10.4 you were introduced to the way one intensifies or emphasises the sizes or qualities of things in Pidgin. Now besides doing this one can also compare the sizes or qualities of two or more things. For example, in English, one says, This dress is (very much) better than that one. In Pidgin there are several common ways of doing this but for the purposes of this course we shall only be drilling those exemplified in the following sentences: 1

1. Dispela moran i moa longpela long dispela. This python is longer than this one.

2. Dispela moran i longpela olsem dispela. This python is as long as this one.

3. Dispela moran i moa longpela $\left\{\frac{\text { tiklik }}{\text { tru }}\right.$ long dispela. This python is $\begin{aligned} & \text { slightly } \\ & \text { considerably }\end{aligned}$ longer than this one.

4. Tasol, dispela moran i longpela bilong winim ol. But this python is the longest of them.

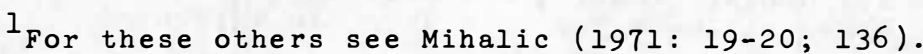


Note that the same constructions can be used with adverbs also, e.g.,

1a. Em i wokim baret moa hariap long mi.

He dug the trench faster than I did.

2a. Em i wokim baret harlap olsem mi.

He dug the trench as fast as I did.

3a. Em i wokim baret moa hariap liklik long mi.

He dug the trench slightly faster than I did.

4a. Tasol em i wokim baret hariap bilong winim ol. 1

But he dug the trench the fastest.

Finally note that moa gutpela can also be sald moa gut or mobeta.

\section{Practice Drills}

\section{Exercise 1: Simple Substitution}

Frame: Mi lukim wanpela moran i longpela liklik.

(longpela moa, longpela moa yet, longpela tumas, longpela tru, longpela olgeta, longpela liklik)

Exercise 2: Simple Substitution

Frame: Haus bilongen $i$ mobeta long haus bilong mipela. (moa bikpela, moa nupela, moa liklik, moa strongpela, mobeta)

\section{Exercise 3: Simple Substitution}

Frame: Dispela ka i nupela bilong winim olgeta arapela.

(bikpela, liklik, sotpela, longpela, nupela)

Exercise 4: Repeat the following sentences substituting the adjective given as cue for the one contained in the given sentence.

1. Han bilong $\mathrm{mi}$ i moa longpela long han bilong yu.

(klinpela) (pause)

2. Dispela supia long hap i no moa sappela long dispela hia.

(bikpela) (pause)

3. I gat wanpela rot long 0strelya i mobeta long dispela hia long Papua Niu Gini.

(longpela) (pause)

4. 01 man bilong Papua $i$ moa smatpela long ol man bilong Niu Gini.

(sotpela) (pause)

5. Husat i longpela bilong winim ol?

(lapun) (pause)

${ }^{1}$ Also Tasol em i winim mi long wokim baret. 
Evaluation Exercises

Exercise 1: Open your book and look at the lines given therein and then answer, in Pidgin, the questions about them given by the instructor:

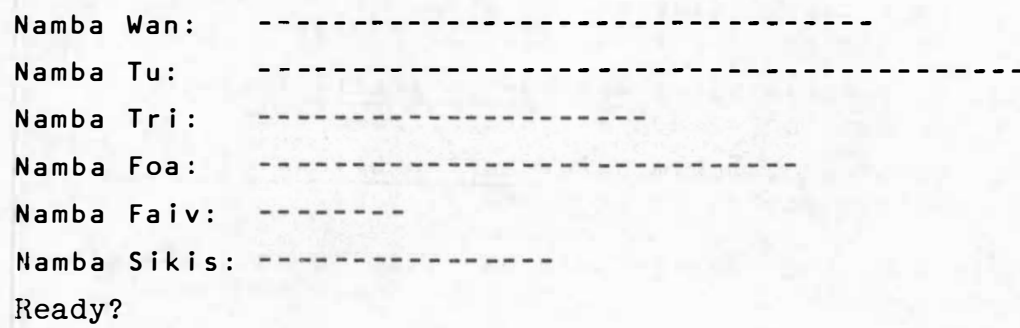

1. Wanem lain i longpela bilong winim ol?

(pause) Lain namba tu i longpela bilong winim ol.

2. Wanem lain i moa sotpela long namba sikis? (pause) Lain namba faiv i moa sotpela long namba sikis.

3. Wanem lain i sotpela bilong winim olgeta arapela? (pause) Lain namba faiv i sotpela bilong winim olgeta arapela.

4. Kolim nem bilong ol lain i moa longpela long namba sikis?

Em hia: namba wan, namba tu, namba tri, namba foa; em ol i moa longpela long namba sikis.

5. Wanem lain i longpela olsem namba foa? (pause)

I no gat wanpela lain i longpela olsem namba foa.

Exercise 2: How would you say the following things in Pidgin?

1. Dogare is taller than Wanipe. (pause)

Dogare i moa longpela long Wanipe.

2. Wanipe is really much taller than MALOLO. Wanipe i moa longpela tru long MALOLO.

3. Dogare is not as strong as Wanipe but is stronger than MALOLO.

Dogare i no strongpela olsem Wanipe tasol i moa strongpela long MALOLO.

4. This bicycle is only moderately priced. Prais bilong dispela wilwil i antap liklik tasol.

5. Whose i.s the best bow? (pause)

Banara bilong husat i gutpela bilong winim ol?

6. My dog habitually fights better than this one of yours.

Dok bilong mi i save pait mobeta long dispela bilong yu. 
7. I have a netbag which is really big.

(pause)

Mi gat wanpela bilum i bikpela tru.

8. He dug the trench as fast as I did.

(pause)

Em i wokim baret hariap olsem $m i$.

9. Where is the unbelievably fat woman?

(pause)

Dispela meri i draipela olgeta, em i stap we?

10. This finger of his is as long as this one.

(pause)

Dispela pinga bilong han bilongen i longpela olsem dispela.

\subsection{LARIM AND SIMILAR VERBS}

In sentences in which such verbs as larim let, allow, tokim tell someone to do something, singautim call out to, helpim help, and mekim to cause or make someone/something do something occur and are followed by other verbs (or adjectives) the predicate marker i must be used before those following verbs (or adjectives) for all subjects. Thus, for example, in Mi larim yu i kaikai I let you eat where larim is followed by kaikai the predicative marker appears before kaikai even though yu is one of those pronouns that the predicate marker does not normally occur with. Study the following examples:

Papa bilong mi i larim mi i draivim ka bilongen.

Gavman i mekim mipela i planim kokonas.

Yu singautim mi i kirap o nogat?

Bai san i mekim klos i drai.
My father lets me drive his car.

The Government makes us plant coconuts.

Did you call out to me to get up or not?

The sun will make the clothes dry or The sun will cause the clothes to dry.

It can be seen that this usage is different from other cases of verbs

in sequence, e.g.

Mi sindaun kaikai. I sat down and ate.

\section{Practice Drills}

Exercise 1: Simple Substitution

Frame: Papa bilong mi i larimmi i draivim ka bilongen.

(mekim, tokim, singautim, helpim, larim)

\section{Exercise 2: Progressive Substitution}

Frame: Husat i larim yu i kam wantaim mipela?

Husat i mekim " " "

$\begin{array}{cccccc}\text { Husat i tokim } " \text { " } & \text { " } & \text { " } & \text { " }\end{array}$

" " " yu i pulapim kap bilongen long ti?

[continued overleaf] 


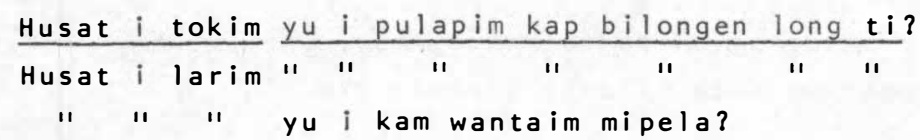

Exercise 3: Give answers to the following questions using the Pidgin cues provided. Ready?

1. Husat i larim yu i kam wantaimmi? (mama bilong mi) (pause) Mama bilong mi i larim mi i kam wantaim yu.

2. Long wanem de masta i tokim yupela i mas katim gras?

(long tripela de $i$ go pinis) (pause)

Long tripela de $i$ go pinis masta $i$ tokim mipela $i$

mas katim gras.

3. I gat haumas man i singautim yu i kam tokim mi i go long haus sik? (tupela man tasol) (pause)

I gat tupela man tasol i singautim mi i kam tokim yu $i$ go long haus sik.

4. Wanem samting i kam mekim kaikai i sting?

$$
\text { (ating wanpela rat) (pause) }
$$

Ating wanpela rat i kam mekim kaikai i sting.

5. Husat i helpim yu i hipim ol kopra long nambis?

(ol tambu bilong mi) (pause)

01 tambu bilong mi i helpimmi i hipim ol kopra

long nambis.

\section{Evaluation Exercise}

How would you say the following things in Pidgin?

1. Make the child get down!

(pause)

Yu mekim pikinini i kam daun!

2. Leave it there!

(pause)

Larimem i stap!

3. Let the Bird of Paradise go!

(pause)

Larin kumul i go!

4. She sang out to me to bring her a knife.

(pause)

Em i singautim mi i kisim (wanpela) naip i go longen.

5. Does your uncle let you eat flying-fox or not?

(pause)

Kandere bilong yu i larim yu i kaikai blakbokis o nogat?

6. Come and help me hang up this string bag!

(pause)

Yu kam helpim mi i hangamapim dispela bilum!

7. Would you fellows go and tell those boys not to say those tinings!

Yupela go tokim ol dispela manki i no ken mekim kain tok olsem/dispela kain tok. 


\section{TEXT}

Listen to the following text about what a hausboi does by a speaker from near Dreikikir in the East Sepik District. Then see how much of it you can transcribe and translate. Here is the text:

Pasin bilong wokim kaikai, olsem. Yu...kirapim stov, orait, yu kukim kaikai nau. I gat patete, anien, no kabis, letis wanem ${ }^{1}$ samting yu mas boilim. Boilim pastaim, troimwe sol, orait, yu rausim wara putim i go i stap, ${ }^{2}$ orait yu praimmit nau. Praimmit, wanem kain kaikai ol i laikim, orait, yu wokim sup no--yu wokim draipela kaikai orait mas draipela (?) kaikai--sapos ol i laikim sup, yu wokim sup, orait ol i mas dring sup pastaim. Orait, yu rausim plet bilong sup samting, orait, em nau. Bihain yu sutim kaikai i gobihain. 01 i kaikai pinis, sapos ol i laikimbilong dring kopi no ol i laikim long dring ti, orait, yu rausim plet nau yu kisim kap, suga samting i kam putim nau. Orait, yu putim nau, yu rausimplet, ol samting i go nau, em nau, ol i wokim ti samting, ol i dring. I go wantaim kaikai.

Orait pasin bilong wokim bet samting tu, olsem. Long--i moningtaim yu wokim kaikai ol i kaikai pinis ol i go long wok, orait, yu brumim haus, wokim bet. Sapos i gat sampela klos samting, yu wasim. Orait sapos i gat--eh--samting bilong ain, orait i gat--sapos i gat lait, ${ }^{3}$ yu ken ain long ainswit ${ }^{4}$ sapos i no gat lait i gat narapela kain ain olsem ain bensin, tasol save pulimapim kerasin na pamim, laitim spirit na pamim. I lait pinis yu kirapim na i--larim--i stap liklik na hat nau, orait yu ain nau. Ain i go pinis, olgeta samting yu ainim pinis, orait yu stretim nau, yu klinim dispela ain, yu kisim samting i go long kapet. Lainimgut, bilong misis i go narapela, bilong masta $i$ go narapela. Em wok bilong hauskuk hia. Em tasol. Mi toktok.

[Playing time: 2.25 minutes]

\section{ENGLISH TRANSLATION :}

Preparing food is done this way. You light the stove then you cook the food. (If) there are potatoes, onions or cabbage, lettuce or whatever (then) you must boil (these). Boil (them) first then add salt then you throw out the water and put these (vegetables) down (somewhere) and let them stand (lit. put them, they stay). Then you

${ }^{1}$ Pronounced wane.

$2 i$ stap is not the continuous marker here but a separate verb as in Unit 1 .

3 lait $=$ electricity.

4 ainswit = electric iron. 
fry the meat. You fry the meat and whatever else they want then you make soup or-you make plenty of food then (?) food. If they want soup you make soup then they must drink the soup first. Then you take away the soup plates and other things and you're ready for the next course (lit. and that's it). Then you follow that with the main course. When they have eaten that if they want to drink coffee or tea then you take away the dinner dishes and bring in cups, sugar etc. and put them (on the table). Then when you've put them you take away the plates and other things and then they (can--lit. and that's it) make (their) tea and things and drink it. It's part of the meal.

And making beds and other (housework) is like this. In the morning you make breakfast and when they've eaten they go to work. Then you sweep out the house and make the beds. If there are clothes and things to be washed you wash them. If there are things to be ironed all right--if there is electricity you can iron with an electric iron. If there is no electricity there is another kind of iron, a petrol/ pressure iron, but (you have) to fill it up with kerosine and pump it and then light the (methylated) spirits and pump it. When it's going (lit. burning) you begin and--leave it--stand a while and then (when) it's hot you iron. And so you iron until there's nothing left (lit. when the ironing's completed) you put the ironed clothes in order, then you clean the iron (11t. this iron, the one we are talking about) and you take things to the cupboard. You put them in neatly--those for the woman of the house in one place and those for the man in another. That's the work of a houseboy. That's all. I've spoken.

Now to end this unit here is a Pidgin song composed by one of the singers about girls who dye their hair white with peroxide.

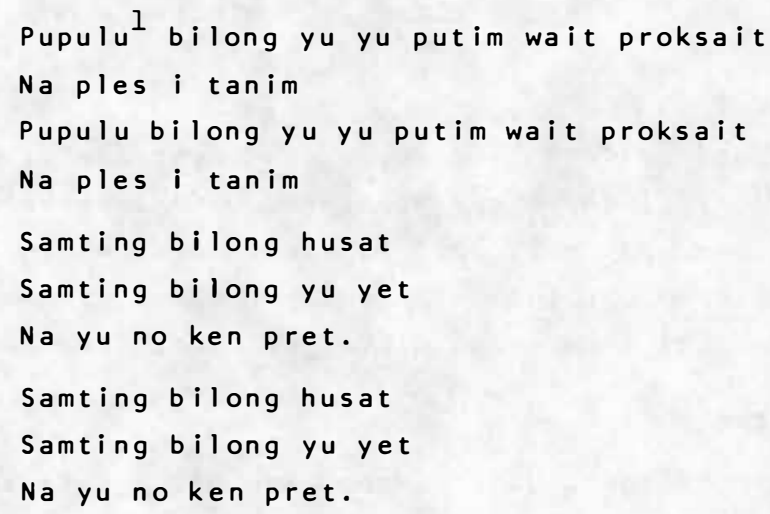

$I_{\text {pupulu }}=$ mararar $=$ love charm. 


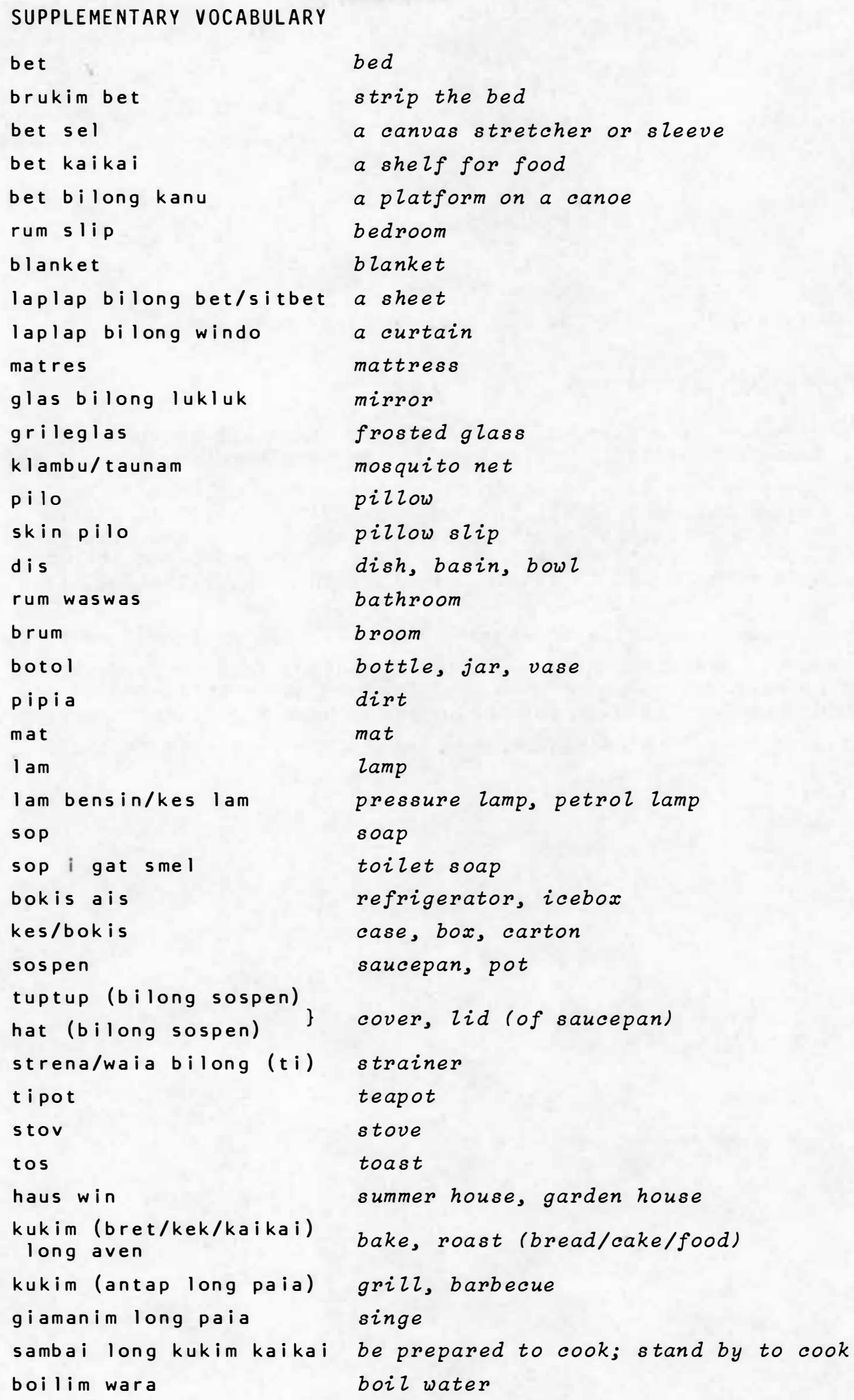




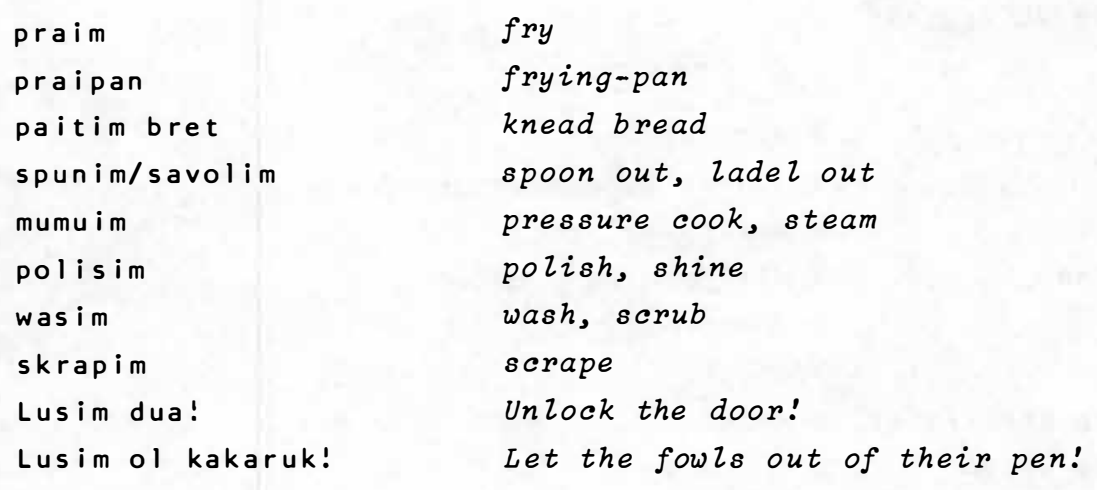

\section{CLASSROOM EXERCISES}

1. Show pictures of a European household and check of $f$ the names for various items of furniture etc. given in the supplementary vocabulary. 2. Give out cards on each of which is written some European concept or item the student is not likely to have thought much about in Pidgin before (e.g., a computer, hippie, insurance agent etc.) and then ask students to stand up and explain the concept or describe the item to the class as best he can in Pidgin. Discussion and questioning may follow.

3. Do the crossword puzzle in Wantok, Namba 4. [No published answer.]

4. Pretend you are a reporter. Cut out a picture from any newspaper (excluding Wantok) and write up a small column about it in Pidgin for display on a notice board or for inclusion in Wantok. Teacher corrects.

5. Listen to one of the supplementary tapes or a text from Unit 16. 


\section{UNIT 13}

CONVERSATION

Long Draivim Ka

Dogare i lainim pasin bilong draivimka. Tasol maski em i hatwok tru em i no kisim save kwiktaim. Olsem na Wanipe i skulim em moa long wanpela wanpela samting bilong draivim ka.

Wanipe: Orait, kirapim ensin olsem mi bin soim yu!

Dogare: Okei. Yu lukim!

Wanlpe: Holit! Holit! Ating yu lusim tingting long gia stik hia a?

Dogare: 0 sori, i tru. Em i no stap long ples b i longen.

Wanipe: Tru. Maski ka i stap we o maski wanem taim yu laik i kirapim ensin yu mas lukluk gut long dispela na putim em i go long namel pastaim. orait, stretim!

Dogare: 01 sem a?

Wanipe: Em! Orait, kirapim ensingen.

(Nois bilong ensin)

Wanipe: Gutpela! Orait, na taim yu laikimka i ran i go
Dogare is learning how to drive

a car. But although he is working hard at it he is not learning very quickly. And so wanipe is teaching him more about different aspects.

ok, start the engine like I showed you to.

Alz right, watch this!

Hold it! Haven't you forgotten about the gear stick?

Oh dear, yes. It's not in its correct position.

Yes. No matter where the car is or what time you want to start the engine you must be careful of that and put it in neutral first. All right, fix it up!

Like that eh?

That's it. Ok start the engine again.

(Engine noise)

Good! Now when you want the car to move forward you must [continued overleaf] 


$$
\begin{aligned}
& \text { yu mas subim klas i go } \\
& \text { daun pastaim na subim } \\
& \text { gia bihain. Save? }
\end{aligned}
$$

Dogare: Ating.

Wanlpe: Orait, yu traim wokim olsen.

Dogare: 0 sori, mi no harim gut. Yu tokim mi gen!

Olsem na tupela i hatwok tru long draivim ka. depress the clutch first and then move the gear stick. Do you get it?

I think so!

ok, try it.

I'm sorry, I äidn't get it properly. Would you please te $l l$ me again!

And so the two of them battle to drive the car.

USEFUL EXPRESSIONS

Em $\left\{\begin{array}{l}\text { rong } \\ \text { asua }\end{array}\right\}$ bilong yu a?

That's your mistake/fault isn't it?

Mi no inap go moa; taia i plat.

Mi no inap go moa; taia i slek.

Mi no inap go moa; bateri i kol.

I can't keep it up; I'm finished.

Mi no inap go moa; bensin i pinis.

Tasol yu putim long foawil draiv. Well draw on your reserve power!

\section{VOCABULARY EXPANSION EXERCISES}

Exercise 1: Simple Substitution

Frame: Dogare i lainim pasin bilong draivimka.

$\begin{array}{ll}\text { stapim ka } & \text { (stopping a car) } \\ \text { bautim ka } & \text { (turning a car around) } \\ \text { oraitim ka } & \text { (fixing a car) } \\ \text { abrusim narapela ka } & \text { (overtaking) }\end{array}$

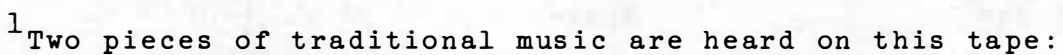

(a) Bot Ke-ke-ke from the Waria River. This is a song and dance performed by dancing drummers. It is to be followed by the feast of a successful harvest. [Sheridan (1958: side l, track 6, item d)]

(b) Barika.sia from the Siassi Islands in the Vitiaz and Danpier Straits. This is massed singing cries in a surging style, from a ceremony to welcome home traders from their canoe voyage to the New Guinea mainland.

[Sheridan (1958: side 2, track 2, item b)]

The former is heard separating the conversation and vocabulary material and the latter elsewhere. 
Frame: Dogare i lainim pasin bilong abrusim narapela ka. goapim ${ }^{1}$ maunten long ka (driving up a hizl)

draivim ka

Exercise 2: Simple Substitution

Frame: Orait yu kirapimensin olsem mi bin soim yu.

$\begin{array}{ll}\text { sloimka } & \text { (slow down) } \\ \text { tanimstia } & \text { (turn the steering) } \\ \text { hariapimensin } & \text { (speed up the engine) } \\ \text { legoimbrek } & \text { (release the brake) } \\ \text { stirimka } & \text { (steer) } \\ \text { kirapimensin } & \end{array}$

Exercise 3: Simple Substitution

Frame: 01 sem na tupela i hatwok tru long draivim ka.

$\begin{array}{ll}\text { nogutim wilwil } & \text { (wreck the bicycle) } \\ \text { draivimbalus } & \text { (pilot a plane) } \\ \text { pulimkanu } & \text { (row a canoe) } \\ \text { kapsaitimkanu } & \text { (capsize a canoe) } \\ \text { bamim narapela } & \text { (bump or run into another) } \\ \text { draivimka } & \end{array}$

Exercise 4: Simple Substitution

Frame: Tasol maski em i hatwok tru em i no kisim save kwiktaim.

$\begin{array}{ll}\text { sindaun gut } & \text { (behave himself) } \\ \text { mekim poisin } & \text { (made magic) } \\ \text { daunim marasin } & \text { (drank medicine) } \\ \text { kaikai buai } & \text { (ate betel-nut) } \\ \text { tanim long masalai } & \text { (turned into a spirit) } \\ \text { hatwok tru }\end{array}$

13.1 MASKI + CLAUSE: although, no matter, even if

Clauses preceded by maski express the 1dea of although or no matter in Pidgin, e.g.,

Maski em i hatwok tru em i no kisim save kwiktaim.
Although he works hard he doesn't learn quickly. No matter that he works hard he doesn't learn quickly.

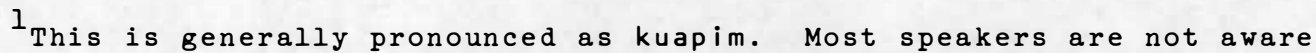
of the relationship between this form and go + ap.
} 
Maski mi sik mi save go long taun.

Maski yu stap we, God i lukim yu.

If one wants to strengthen this idea to even if one merely adds tasol

to the beginning of the following clause, e.g.,

Maski em i hatwok tru, tasol em

i no kisim save kwiktaim.
Although I am sick I stizl (= habitually) go to town (or I still go to tcwn although I am sick).

No matter where you are God sees you.

Notice, however, that in all cases the maski clause always comes first in Pidgin whereas in English the although, no matter and even if clauses may come before or after other clauses, e.g., Although he works hard he doesn't learn quickly and He doesn't learn quickly although he works hard.

Practice Drills

Exercise 1: Simple Substitution for although

Frame: Maski yu no laik i ritimbaibel, mi no ken krosim yu. (prenim masta, givim mani longen, rausim pipia, helpim mi, ritim Baibel)

Exercise 2: Simple Substitution for no matter

Frame: Maski yu stap we, God i lukim yu.

(yu husat, long wanem taim yu kam, yu mekim wanem, yu stap we)

Exercise 3: Simple Substitution for even if

Frame: Maski kiap i kam, tasol mipela i no peim takis.

(oraitim rot, karim kago, bulsitim em, bilasim ples, peim takis)

Exercise 4: Make corresponding even if sentences to the following although ones by adding tasol to the beginning of the second clause. Ready?

1. Maski yu save wokim banara bilong mi, mi no laikim wanpela.

(pause)

Maski yu save wokim banara bilong mi, tasol mi no laikim wanpela.

2. Maski ol i planim kopi, bai ol i no kisimbikpela pe longen.

Maski ol i planim kopi, tasol bai ol i no kisim bikpela pe longen. 
3. Maski misis i traim kilim i dai em yet, em i no inap. (pause) Maski misis i traim kilim i dai em yet, tasol em i no inap.

4. Maski yu no inap i kam long pati, yu salim pas i kam. (pause) Maski yu no inap i kam long pati, tasol yu salim pas i kam.

5. Maski dok i no hangre, em i save kaikai. (pause)

Maski dok i no hangre, tasol em i save kaikai.

Exercise 5: Join the following pairs of sentences together to make although, no matter and even if sentences by adding maski, or maski and tasol in the correct places. English cues will be given to indicate which type of sentence is required. Ready?

1a. Yu no les.

1b. Yu mas malolo. (even if) (pause)

A: Maski yu no les tasol yu mas malolo. Even if you are not tired you must rest.

2a. San i gondaun.

2b. Yumi i ken brukim graun. (although) (pause)

A: Maski san i gondaun, yumi i ken brukim graun. Although the sun is going down, we can plough the ground.

3a. Em i hait we.

3b. Mi ken painim em. (no matter) (pause)

A: Maski, em i hait we, mi ken painim em.

I can look for him no matter where he is hiding.

4a. Yu katim dispela kain diwai liklik tasol.

4b. Em i save pundaun.

(even if) (pause)

A: Maski yu katim dispela kain diwai liklik tasol, tasol em i save pundaun.

Even if you only cut this kind of tree a little it still falls down.

5a. Yu kilim i dai husat.

5b. Gavman bai em i kalabusim yu. (no matter) (pause)

A: Maski, yu kilim i dai husat, Gavman bai em i kalabusim yu. No matter whom you kill the Government will jail you.

6a. Yu laik i draivim ka.

6b. Yu mas kisim laisen pastaim.

(even if) (pause)

A: Maski yu laik i draivim ka, tasol yu mas kisim laisen pastaim. Even if you want to drive a car you must get a licence first.

7a. Em i karamapim tok olsem.

7b. Mi save laik bilongen. (although) (pause)

A: Maski em i karamapim tok olsem mi save laik bilongen. Although he is being vague I know what he wants. 


\section{Evaluation Exercise}

How would you say the following things in Pidgin?

1. Although Dogare started the car he couldn't drive it. (pause)

Maski Dogare i kirapim ensin, em i no inap draivimka.

2. I'll not: let you ride the bicycle even if I fix it. (pause) Maski mi oraitim wilwil, tasol bai mi no larim yu i wokabaut longen.

3. No matter who is sleeping in the house this rooster always crows.

Maski husat i slip long haus dispela kakaruk man (em) $i$ save singaut (oltaim oltaim).

4. We(3 excl.) ran into a tree although we were going carefuzly.

(pause)

Maski mitripela i go isi isi, mitripela i bamim wanpela diwai.

5. They should not overtake another car even if the road is clear.

Maski rot i klia, ol i no mas abrusim narapela ka.

6. He is stizl dirty although he washes every day.

(pause)

Maski em i waswas olgeta de em i stap doti.

7. Even if you have an accident don't run away!

(pause)

Maski yu kisim $\left\{\begin{array}{l}b i r u a \\ a s u a\end{array}\right.$ yu no ken ranewe!

8. Australia must continue to assist Papua New Guinea even if she gets self government.

(pause)

Maski Papua Niu Gini i kisim selp gavman, tasol Ostrelya

i mas helpim em i stap.

9. No matter where you are send me a letter.

Maski yu stap we, yu salim pas i kam long mi.

(pause)

10. Although my sister is dead $I$ do not forget her.

Maski susa bilong mi i dai pinis, mi no lusim tingting longen.

\subsection{DISTRIBUTIVE AND RECIPROCAL PRONOUNS: each, one another}

In Pidgin there is no one way of expressing the idea of each other or one another. Most generally this is achieved by repeating numerals, e.g.,

Tupela i paitim wanpela wanpela. ${ }^{1}$ They(2) hit each other.

Wanpela wanpela i kisim pe Each one collected his wages.

bilongen.

01 i kisim tupela tupela. They received two each.

lwanpela wanpela is also heard as wanwan. 
Tupela tupela i kisim wanpela blanket.

but this is limited so that one often has to explain the circumstances before it is clear what is being said, e.g.,

Tupela man i pait; wanpela i paitim wanpela. 1

Planti man i pait; ol i paitim ol wanpela wanpela.

Ai bilong mi i lukim yu na ai bilong yu i lukim mi; yumitupela i lukim yumitupela.

Note also that repetition of numerals may have different meanings in different sentences. Compare those above with the following:

01 i kamap wanpela wanpela. They came up one by one.

Practice Drills

Exercise 1: Simple Substitution for each other

Frame: Tupela i paitim wanpela wanpela.

(sutim, helpim, wasim, givimgude long, sekan long, pait im)

Exercise 2: Simple Substitution for each two

Frame: Tupela tupela i kisim wanpela blanket.

(wokim, stilim, bringim i kam, brukim, kisim)

Exercise 3: Simple Substitution for one by one

Frame: 0lgeta i kamap wanpela wanpela.

(sindaun, idai pinis, krai, sanap, kamap)

Exercise 4: Change the repeated numerals in the following sentences to those given as cues:

1. Tupela tupela i kisim wanpela blanket. (tripela tripela) (pause)

Tripela tripela i kisim wanpela blanket.

2. 01 i nildaun wanpela wanpela.

(tupela tupela) (pause)

01 j nildaun tupela tupela.

3. Wanpela wanpela i sutim wanpela pik. (tupela tupela) (pause)

Tupela tupela i sutim wanpela pik.

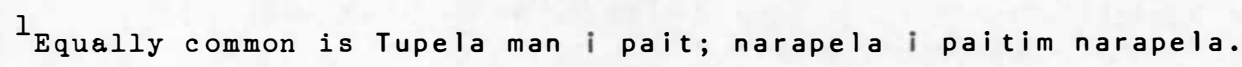


4. Bai mipela i sanap wanpela wanpela o nogat?

(faivpela faivpela) (pause)

Bai mipela i sanap faivela faivpela o nogat?

5. Husat i tok, "Ol i ken i go insait long haus tambaran

tupela tupela." (wanpela wanpela) (pause)

Husat i tok, "Ol i ken i go insait long haus tambaran

wanpela wanpela.

\section{Evaluation Exercise}

Repeat the following sentences and say what they mean in English:

1. Em rong bilong yutupela. Bilong wanem yutupela $i$ tok nogutim yutupela?

(pause)

That's your fault, you two. Why did you(2) abuse each other.

2. Planti man i pait; ol i paitim ol wanpela wanpela.

(pause)

Many men fought; they hit each other.

3. 01 sem wanem tupela i katim wanpela wanpela?

(pause)

How did the two of them cut each other?

4. Ai bilong yu i lukim mi na ai bilong mi i lukim yu; yumitupela i lukim yumitupela.

(pause)

we see each other.

5. Tripela tripela i mas slip long wanpela bet, bilong wanem blanket $i$ no inap long olgeta.

(pause)

Each three must sleep in the one bed because there are not enough blankets for all.

\subsection{TRAIM: try or attempt}

The idea of trying or attempting to do something is most commonly expressed in Pidgin by placing traim before the verb, e.g.,

Yu traim bautim dispela longpela kanu.
Try to turn this long canoe around.

However, depending on circumstances traim may alternatively be placed after the verb or the object but this is less acceptable if the objects of the sentences are pronouns or long phrases, e.g.,

Yu bautim traim dispela

longpela kanu.

Yu bautim disfela longpela

kanu i traim.

* Yu bautim dispela longpela kanu i stap long hap i traim.

*Yu bautim trâim em.

Yu traim bautim em.
Try to turn this long canoe around.

Try to turn this long canoe around.

Try to turn that long canoe around that is up there.

Try to turn it around.

Try to turn it around. 
Finally, note that if one wants to draw particular attention to the object of the action then this may be mentioned first in the sentence. For example, if one were making a bow for a friend and he came and asked what it was that you were making (as against what you were doing) you would probably answer Banara yu bin askim mi longen, em $m i$ traim wokim It's the bow you've been asking me for that I am trying to make.

\section{Practice Drills}

Exercise 1: Simple Substitution

In this exercise you are going to repeat the same material in three different frames which are variants of each other. In the first frame traim will appear before the verb; in the second after the verb; and in the third after the object. Ready?

Frame 1: Yu traim bautim dispela longpela kanu.

(legoim, hariapim, stirim, stapim, bautim)

Frame 2: Yu bautim traim dispela longpela kanu.

(legoim, hariapim, stirim, stapim, bautim)

Frame 3: Yu bautim dispela longpela kanu i traim.

(legoim, hariapim, stirim, stapim, bautim)

Exercise 2: Repeat the following sentences placing traim after the object. Don't forget the predicative marker! Ready?

1. Liklik manki i traim draivim ka.

(pause)

Liklik manki i draivimka i traim.

2. Tisa i traim haphapim wok bilongen.

(pause)

Tisa i haphapim wok bilongen i traim.

3. Susa bilong mi i traim pulapim kap long $t i$.

(pause)

Susa bilong mi i pulapim kap long ti i traim.

4. Stilman i traim karamapim tok.

(pause)

Stilman i karamapim tok i traim.

5. Oltaim kalabusman i kaikai traim planti tumas.

(pause)

oltaim kalabusman i kaikai planti tumas i traim.

Exercise 3: Repeat the following sentences placing traim immediately before the verb. Ready?

1. Bilong wanem ol i abrusim dispela trak i traim?

(pause)

Bilong wanem ol i traim abrusim dispela trak?

2. Yupela i no ken bamim narapela wilwil i traim!

(pause)

Yupela $i$ no ken traim bamim narapela wilwil! 
3. Sapos em i kam, orait bai mitupela i ken brukim dispela wara i traim.

(pause)

Sapos em i kam, orait bai mitupela i ken traim brukim dispela wara.

4. Husat i laik i goapim wanpela kokonas i traim?

(pause)

Husat: i laik i traim goapim wanpela kokonas?

5. Larimmi i draivimbalus i traim.

(pause)

Larimmi i traim draivimbalus.

Evaluation Exercise

Pretend you have a Pldgin-speaking frlend and explain to him the meaning of the following English sentences in Pldgin. In his answer the instructor will give three possible varlants for each. Ready?

1. He's trying to play a jew's harp.

(pause)

Em i traim pilai susap.

Em i pilai traim susap.

Em i pilai susap i traim.

2. When you want to make a fire try to find some dry wood.

(pause)

Taim yu laik i mekim paia yu mas traim painim sampela paiawut i drai.

Taim yu laik i mekim paia yu mas painim traim sampela paiawut i drai.

? Taim yu laik i mekim paia yu mas painim sampela paiawut i drai i traim.

3. I tried to get some green coconuts but I couldn't find any.

(pause)

Mi traim painim sampela kulau, tasol nogat.

Mi painim traim sampela kulau, tasol nogat.

Mi painim sampela kulau i traim, tasol nogat.

4. Who wizl try to carry me?

(pause)

Husat i traim karim mi?

Husat i karimmi i traim?

?Husat i karim traimmi?

5. My mother is trying to bake a cake.

(pause)

Mama bilong mi i traim kukim kek long aven.

Mama bilong mi i kukik kek long aven i traim.

Mama bilong mi i kukim traim kek long aven. 
TEXT

Listen to the following story told by a P.M.V. driver from Misim village in the East Sepik District, and then see how much of it you can transcribe and/or translate. Here is the story:

Wanpela de mi kirap long ples bilong mi, long Misim, orait mi kam daun, kamap long rot, long Pelnandu, na mi kam. Mi kam mi lusim Pelnandu mi kam daun long maunten na mi kam long ples stret, mi kam antap long wanpela ples ol i putim wetsan bipo. Orait, mi putim seken $^{1}$ gia antap, na mi kam daun. Taimmi kam daun $i$ stil $^{2} i$ gat liklik brekwel tasol, na mi kam daun. Mi kam daun stret long maunten nau, mi laik putim pes gia long kam daun. Mi putim lek long brek, nating: ${ }^{3}$ I go pas long plua. Orait, mi tingting. Mi kam daun long maunten tingting bilong mi $i$ lus pinis. Mi kam daun long maunten, mi tingting. Mi laik putim ka i go antap long maunten, orait, bihain mi kapsait i kam daun long rot. Nogat, wanpela tingting i kamap. Nau mi tok, "o, nogut mi putim ka i go antap, mi kapsait i kam daun long rot, bai ol i tok, 'A, mi draiva nogut, mi bagarapim ka.'"l Orait, mi kam daun, stret long ples long poin ${ }^{4}$ stret, long ples daun, as bilong saksak, klostu long wara--long Wer, mi tanim kwik stia i go antap long liklik hap maunten tasol, na mi laik tanim i kam daun gen, mi kam slo. Mi kam kamap long bris, na tingting bilong mi i stap rait ${ }^{5}$ nau na mi kamap antap long maunten. Em tasol liklik hap tok bilong mi.

\section{[Playing time: 1.75 minutes]}

\section{ENGLISH TRANSLATION :}

One day I started from my vilzage, Misim, and I came down, arrived at the road, at Pelnandu, and I came. I left Pelnandu and I came down the mountain and I went straight to the place. I came up to one place (where) they had put sand before. I put the truck in second gear at the top and I came down. At that time there was only a drop of brake fluid still (in the brake system). Right on the mountain I wanted to change into first gear to come down. I put the brakes on-(but) nothing (happened)--(the brake pedal) went right down to the floor boards. So I thought (but as) I was coming down the steep part

$1_{\text {seken }}=$ namba $t u$

2 stil $=$ yet

3 Note use of nating here. Cf. Unit 12 Section 12.2 footnote 2.

4 poin = bend, corner (= kona)

$5_{\text {rait }}=$ right, correct 
my mind went blank. (Then) as I was coming down I thought. I wanted to run the truck up the side of the mountain but (I knew that) it would tip over onto the road. So that was no use. Then an idea struck me, and I said to myself then, "Oh, it wouldn't be wise for me to run the truck up the mountain and tip over on to the road (because) they would oniy say, 'Ah, you're not a good driver, you wrecked the truck.'" So I came down right to the bend, to the dip (where) the sago is (lit. the home/origin of sago), near the creek--at wer and $I$ turned the steering wheel quickly and ran up on to only a small rise and (when) I wanted to come down again I came (down) slowly. I arrived at the bridge and my mind was clear then and I came up the mountain. That's all there is to this small conversation piece of mine.

Now to end this unit here is a recording of bamboo flutes from the East Sepik District. These are introduced by a speaker from near Dreikikir who describes their use in Pidgin, although not altogether too clearly.

Mipela wokim i gat bikpela kaikai, i kamap, olsem krismas long stesin. Orait mipela kirapim mas (?), hangamapim drai, orait em nau mipela wokim dispela stori. Na mipela singsing $i$ go $i$ go $i$ go $i$ go taim mipela laik rausim em gutpela kaikai i kirap. Gutpela kaikai i kirap, manmeri i kisim kaikai pinis, orait, orait em dispela mambu mipela kilim indai. Em stori bilong mi. Draipela pik mipela pasim, lain bilongen $i$ go hap longen hia, hap longen hia, mami kanda, drai kanda, olgeta samting mipela wokim bilas, em i gut bilas, mipela wokim gut...orait rausim samting bilong tumbuna... Em nau dispela mipela wokim, na mi no mi no pilai pilai, nogat, mipela mas wokim tru...samting, orait, na planti...pik, yam mami longpela yam, na ol kaikai i kamap bilas tambaran mipela kamap bilas bilong...na mipela rausim. Em stori bilong mi, nau yu laik kisim em dispela em tasol. Mi tokim yu. Tok pinis.

[Musik]

\section{SUPPLEMENTARY VOCABULARY}

$\begin{array}{ll}\text { bateri } & \text { battery } \\ \text { bateri i kol pinis } & \text { battery is flat } \\ \text { hatim bateri } & \text { charge a battery } \\ \text { bensin } & \text { petrol } \\ \text { sap (bilong naip) } & \text { blade (of knife) } \\ \text { skru } & \text { bolt } \\ \text { mama bilong skru } & \text { nut (of bolt) }\end{array}$




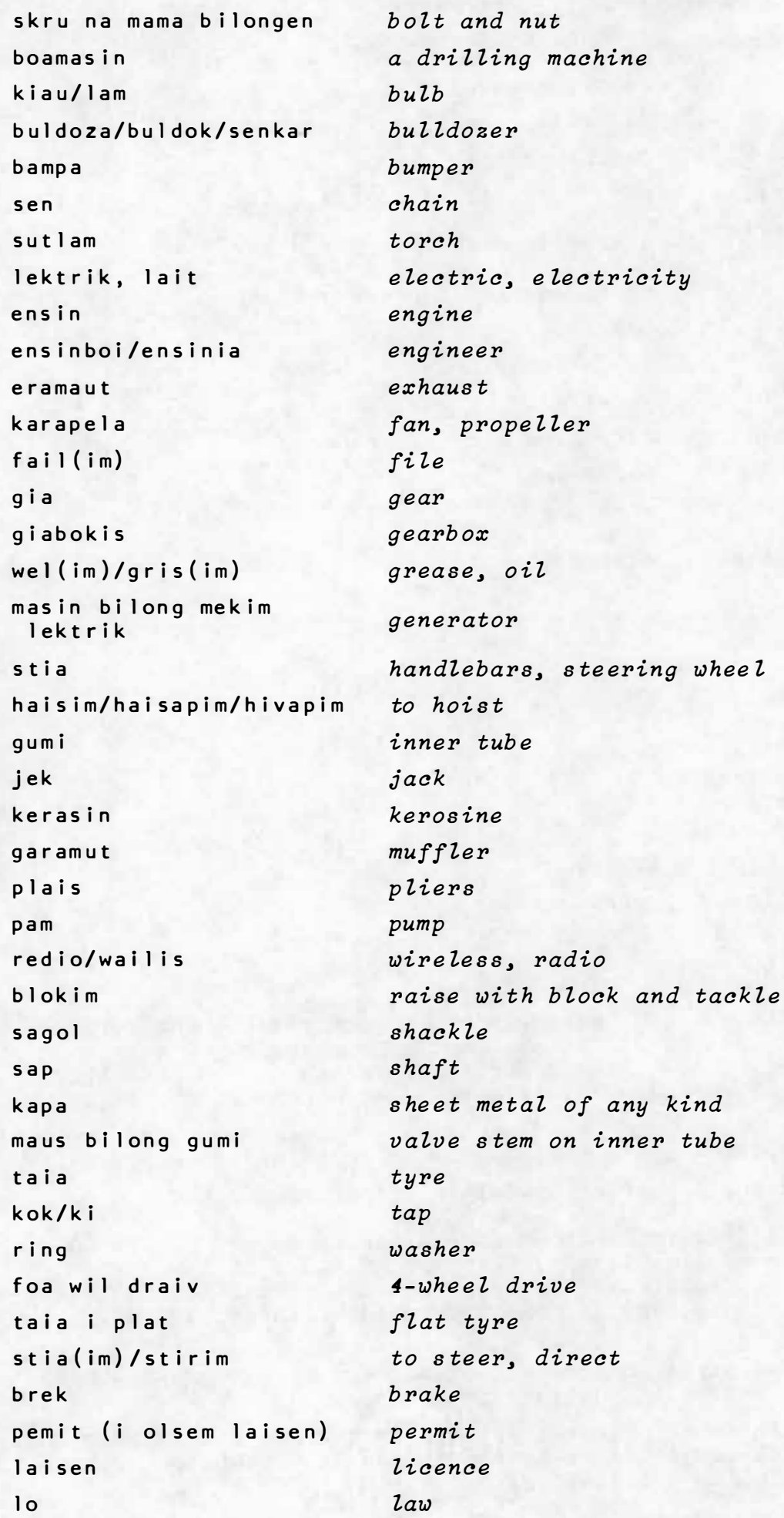




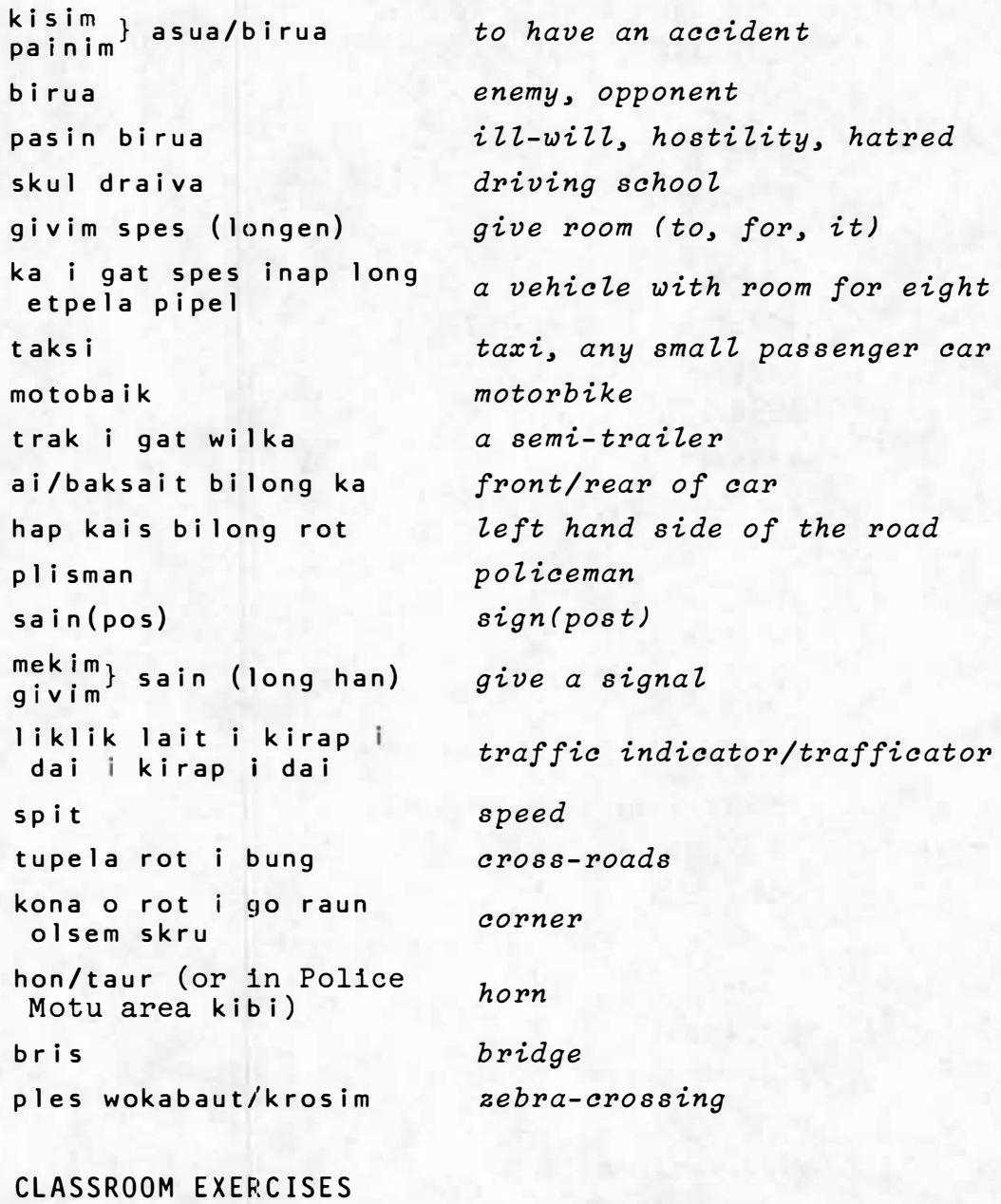

1. Try to explain to someone in Pidgin how to control the accelerator and the clutch when starting off in a car. For example you must explain that while you are lifting one foot of the clutch the other must be giving the car progressively more power otherwise the engine will stall.

2. Practise some driving instruction and road rules using toy cars. [Students may find the following useful in preparing for these exercises:

(a) Learn All about Cars (a handbook for Kanite speakers) published by Summer Institute of Linguistics, Ukarumpa, P.N.G., 1970.

(b) Pidgin Edition of Your Guide to safety (a motor traffic handbook for Papua New Guinea published by the Government Printer, N.S.W., 1969).]

3. Study the written style and content of a group of letters-to-theeditor in Wantok. Report in English.

4. Give out a fascimile of a letter written by a Papua New Guinean in his own hand and ask for (a) a re-transcription into standard orthography and (b) an English translation. 
5. Write a letter in Pidgin to Wantok asking for a subscription or replying to someone's letter-to-the-editor.

6. Pretend you are a policeman interviewing a driver at an accident. Use a portable tape-recorder to keep a record for replay to others for comment and discussion. 


\section{UNIT 14}

CONVERSATION

\section{Long Brukim Marit}

Bihain long taim wok i pinis

Dogare $i$ go long Konedobu bilong pilai wantaim meri bilong

narapela man. Taim em i kamap

long haus bilong dispela meri

man bilongen i krosim em nogut

tru. Man i tok,

Maritman: Yu bladisit! Watpo yu

kam? Yu kam bilong

brukim marit bilong mi

a? 01 sem wanem? Yu

i klia!l

Dogare: Nogat, mi no laik i

brukim marit bilong yu.

Em samting bilong meri

bilong yu. Em yet i

pulim mi. Mi no laikim

em tasol mi man na em i

skrapim bel bilong $\mathrm{mi}$

na mitupela i pilai.

Maritman: $01 \mathrm{sem}$ wanem? Yu no save

lo long wanpela man i no

ken pulim meri bilong

narapela man. Yu inap

baim meri bilong mi?

Nogat, yu yangpela yet

na yu hambak nabaut

tasol. Nau bai mi mekim

wanem? Bai mi rausim

meri bilong mi o wanem?
After work Dogare went to

Konedobu to engage in sexual

relations with another man's

wife. When he arrived at this

woman's house her husband got

very angry. He said,

You bastard! Why have you

come? Did you come to wreck

my marriage? Why? Clear off!

No, I don't want to wreck your marriage. It's your wife, she enticed me. I didn't like her but $I^{\prime} m$ a man and she flattered me and taunted me and we finished up sleeping together.

Why? Don't you know the law about interfering with another man's wife? Can you afford to pay brideprice for my wife? No, of course you can't; you're stizl a kid and all you do is create trouble irresponsibly. Now what will I do? Should I chase my wife out or what?

[footnote opposite] 
Dogare: 0 sori, mi belhevi long

dispela samting tasol

yu no ken putim hevi

long mi wanpela. Em i

trabel bilong meri

bilong yu tu.

Maritman: Ah! Em i tok, "Em yet

i giamanim mi." Mi

ting $i$ mobeta sapos

yumitripela i go long

kot bilong stretim

dinau bilong dispela

trabel.

Dogare: I orait. Bai yumi i

lukim husat i kirapim

dispela. Bai mi tokaut

klia long dispela.
Forgive me, I'm sorry about this but you can't blame just me, your wife's in it too.

Ah (in disgust). She says that you deceived her. I think the best thing to do is for us(3) to go to court and settle this account.

That's Ok. We'll see who started this. I'll make it quite plain.

And so Dogare departs and goes back and waits for the court case.

Orait na Dogare i lusim haus i [Musik ${ }^{2}$ ]

USEFUL EXPRESSIONS

Yu gat bel a?

Yes mi gat. Dispela man em i givim mi.

Yu katim kona a?

oltaim oltaim em i aigris long

ol yangpela meri.

You're pregnant eh?

Yes I am. This is the culprit.

Did you rush things a bit eh?

He's always giving the glad

eye to the teenagers.

Em i hangamap long narapela meri.

$H e^{\prime} s$ "hooked" on another woman.

Mi laikim tang bilong yu.

I want to kiss you.

Husat i seksek long lukim em a?

Who's the one who goes to pieces

when he sees him/her eh?

Samam wantaim kanu i orait.

They are happily married.

\footnotetext{
${ }^{1}$ Note this sharp command which has the predicative marker $i$ in it. Compare it with the normal type Yu klia! Clear off!

2 The traditional music heard on this tape was Ririka Jungun, from Manum Island. In it embeki flutes are played in pairs, turn-for-turn, in a ceremony to declare open the house for the initiated men. This recording comes from Sheridan (1958: side 1, track 2, item c).
} 


\section{VOCABULARY EXPANSION EXERCISES}

\section{Exercise 1: Simple Substitution}

Frame: Yu kam bilong brukimmarit bilong mi a? pilai wantaim meri bilong $\mathrm{mi}$ (to have sexual intercourse goapim meri bilong $\mathrm{mi}$ sutim meri bilong mi " " " " $" \prime$

mekim trabel long meri bilong $m i$ pilai wantaim wanblut bilong yumi bagarapim marit bilong $\mathrm{mi}$ brukim marit
" "with)

" " "

(fornicate with)

(commit incest) (commit adultery)

Exercise 2: Simple Substitution

Frame: Em i skrapimbel bilong mi na mitupela i pilai.

$\begin{array}{ll}\text { traim mi } & \text { (tempted) } \\ \text { laikim mi } & \text { (Zove) } \\ \text { mangalim mi } & \text { (covet, jealous of) } \\ \text { pulim mi } & \text { (enticed) } \\ \text { duim mi } & \text { (forced, challenged) } \\ \text { grisim mi } & \text { (flatter) }\end{array}$

skrapim bel bilong mi

Exercise 3: Simple Substitution

Frame: Yu yangpela yet na yu hambak nabaut tasol.

\begin{tabular}{ll}
\hline lesbaga & (Zoafer) \\
sikibaga & (cheeky person) \\
kusaiman & (prankster, deceiver) \\
paniman & (clown) \\
bikhetman & (stubborn, conceited) \\
welman & (greasy customer, sponger) \\
rabisman & (person of no account) \\
pulman & (fool) \\
dripman & (drifter, squatter) \\
yangpela yet &
\end{tabular}

\section{Exercise 4: Simple Substitution}

Frame: Yu no ken putim hevi long mi wanpela.

$$
\begin{array}{ll}
\text { kalabusim mi wanpela } & \text { (jail) } \\
\text { kotim mi wanpela } & \text { (take to court) } \\
\text { trabelim mi wanpela } & \text { (molest, harm, trouble) } \\
\text { rongimmi wanpela } & \text { (wrong, offend) }
\end{array}
$$


Frame: Yu no ken rongim mi wanpela.

$$
\begin{array}{ll}
\text { ripotim mi wanpela } & \text { (report) } \\
\text { tok win long mi wanpela } & \text { (tell idle tales to) } \\
\text { tok save long dispela samting long mi wanpela } & \text { (explain this thing to) } \\
\text { putim hevi long mi wanpela } &
\end{array}
$$

\section{Exercise 5: Progressive Substitution}

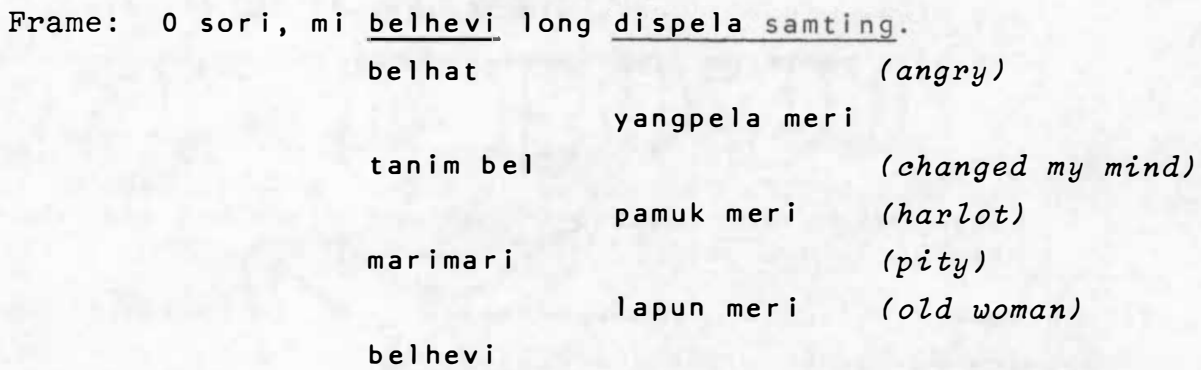

$$
\text { dispela samting }
$$

\section{1 IMPATIENT QUESTIONS: watpo, wasmara, westap}

There are several special question words in Pidgin which always stand at the beginning of the questions they help form but which are generally used to show impatience, annoyance or anger--at least that is how they will be treated in this course for practice purposes. I These question words are: watpo or wasmara why? and westap where is/ are?

Examples :

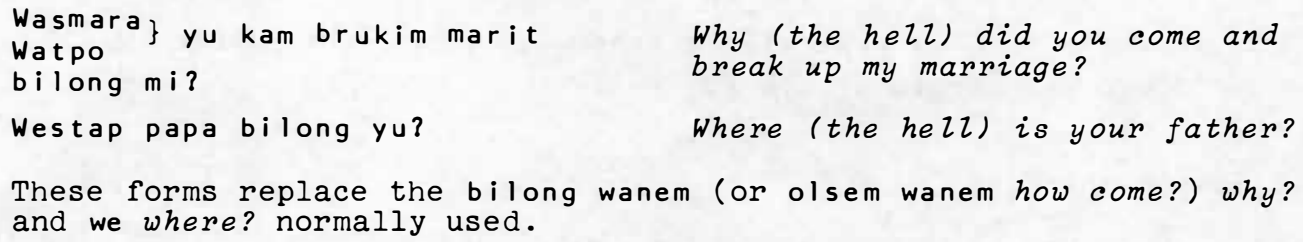

Practice Drills

Exercise 1: Simple Substitution

Frame: Watpo yu sindaun nating?

(traim mi, bulsitim mi, pilai wantaim meri bilong mi, tok nogutim em, sindaun nating)

\footnotetext{
$I_{\text {Tone of }}$ voice is also important, as in English.
} 


\section{Exercise 2: Simple Substitution}

Frame: Wasmara yu stilim mani bilongen?

(laik i grisim mipela, goapim dispela yangpela meri, agens long tingting bilong mi, stilim mani bilongen)

\section{Exercise 3: Simple Substitution}

Frame: Westap papa bilong yu?

(haus kiap, man bilongen, olgeta meri bilong dispela ples hia, pamuk meri, papa bilong yu)

Exercise 4: Change the following normal questions into ones indicating impatience, annoyance, or anger by substituting watpo, wasmara or westap for bilong wanem and we. Cues are supplied. Ready?

1. Bilong wanem yu daunim dispela marasin?

(wasmara) (pause)

Wasmara yu daunim dispela marasin?

2. 01 supia bilong yupela i stap we?

(westap) (pause)

Westap ol supia bilong yupela?

3. Dispela kusaiman yu bin toktok wantaim em, em i stap we?

(westap) (pause) Westap dispela kusaiman yu bin toktok wantaim em?

4. Taim ministeriel memba i kam lukim mipela bilong wanem yu no givim gude longen?

(watpo) (pause)

Taim ministeriel memba i kam lukim mipela watpo yu no givim gude longen?

5. Oltaim oltaim yu krai bilong wanem?

(wasmara) (pause)

Wasmara oltaim oltaim yu krai?

\section{Evaluation Exercise}

How would you ask someone the following questions in Pidgin? You have to choose between the normal question forms and the impatient ones just learned. To help you recognise the latter cases the instructor will modify his volce and intonation and add in the words the hell as well. Ready?

1. Where the hell are my trousers?

(pause)

Westap trausis bilong mi?

2. Why is the butter soft? I don't like it like that!

(pause)

Bilong wanem bata $i$ malomalo. Mi no laikimem olsem.

3. Why the hell is the butter soft? I don't like it like that!

\{Wasmara bata i malomalo? Mi no laikim em olsem.

Watpo bata i malomalo? Mi no laikimemolsem. 
4. Where have all the squatters gone?

(pause)

0 lgeta dripman i go we?

5. Why the hell did he commit incest?

(pause)

\{Watpo em i pilai wantaim wanblut bilongen?

Wasmara em i pilai wantaim wanblut bilongen?

6. I told you to cook rice. But you didn't cook rice. Why the hell didn't you cook rice?

(pause)

Mi tokim yu mi tok, "Yu kukim rais." Tasol yu no kukim rais. Watpo yu no kukim rais? (or Wasmara yu no kukim rais?)

7. Where did you find the canoe?

(pause)

Yu painim pinis kanu we?

8. How come you have a brother in Australia?

(pause)

01 sem wanem yu gat wanpela brata bilong yu long ostrelya?

9. Why the hell did you give money to this angry man?

(pause)

Watpo yu givim mani long dispela man kros hia?

Wasmara yu givim mani long dispela man kros hia?

\subsection{SENTENCE REOUCTION AND SEQUENCE OF TIME}

You should now be quite familiar with joining sentences with na and, o or and tasol but to form larger ones. However, you may not be aware that for certain sentences joined by na one can indicate time differences between the connected actions by varying the amount of information that is repeated in the part of the sentence following na. Thus, for example, a sentence like

01 i sindaun na ol i toktok.

They sat down and then (some time afterwards) talked.

indicates that the actions of sitting and talking do not follow one another closely in time like the following sentences do:

01 i sindaun na i toktok.

They sat down and then (soon afterwards) talked.

01 i sindaun na toktok.

They sat down and then (immediately afterwards) talked.

In general provided the two subjects are the same and the structure of the conjoined parts is similar one can omit increasing amounts of repeated information. For some common intransitive verbs like go, $\mathrm{kam}$, sanap, sindaun even na may be omitted, in which case the idea of simultaneous (or very closely linked) actions is expressed.

01 i sindaun toktok.

Em i kam lukim mi. 1

They sat down talking.

He came and saw me.

For other verbs a similar result can only be achieved by adding wantaim to the second part of the sentence after na, e.g.,

\footnotetext{
${ }^{I_{\text {This }}}$ could also be He came to sée me. Cf. Unit l, Section 1.4.
} 
01 i kaikai taro na toktok wantaim.
They ate taro and talked at the same time.

A sentence like $* 01$ i kaikai taro toktok would be unacceptable.

Practice Drills

Exercise 1: Repeat the following sentences dropping out the repeated subjects. Ready?

1. Tupela i go na (tupela) i brukim haus.

2. Em i senisim siot bilongen na (em) i go long taun.

3. Yu baim balus na (yu) go long Lae!

Exercise 2: Repeat the following sentences dropping out the repeated subjects and predicative markers. Ready?

1. Em i kirap long wilwil na (em i) wokabaut long rot.

2. Balus $i$ pundaun $n a(e m i)$ bagarap.

3. Mipela i redim kaikai na (mipela i) kukim poteto.

Exercise 3: Repeat the following sentences dropping out the $\mathrm{na}$ and the repeated subjects and predicative markers. Ready?

1. Husat i kam (na husat i) stilim kotren bilong mi?

2. Yupela sindaun (na yupela) ritim stori.

3. Em i go (na em i) pilai kikbal a?

Exercise 4: Repeat the following sentences adding wantaim to the end. Ready?

1. Mi pispis na pekpek blut (wantaim).

2. Olgeta i wetim kot na i toktok (wantaim).

3. Mi no inap krosimem na goapim em (wantaim).

Exercise 5: Join the following pairs of sentences together with na to form larger ones deleting parts of the second sentence as required to indicate that the second action was carried out either (a) sometime after; or (b) soon after; or (c) immediately after. The instructor will indicate which of these is required by giving the cues sometime after, soon after and immediately after between the two sentences. For example, if the instructor n'ere to say:

6a. 01 i sindaun. (sometime after)

6b. 01 i toktok.

your answer should be 01 i sindaun na ol i toktok. Fieady?

la. Em i kâm.

(soon after)

lb. Em i lukim mi.

A: Em i kăm na i lukim mi. 
2a. 01 i kam antap long haus bilong mi. (sometime after)

2b. 01 i kaikai taro.

A: 0l i kam antap long haus bilong mi na ol i kaikai taro.

3a. Husat i sanap?

(immediately after)

3b. Husat i singautim bosboi?

A: Husat i sanap na singautim bosboi?

4a. Meri bilongen i mangalim mi.

(sometime after)

4b. Em i pulim mi long pilai wantaim em.

A: Meri bilongen i mangalimmi na em i pulimmi long pilai wantaim em.

5a. Wanpela paniman i kam.

(soon after)

5b. Em i stori long mipela.

A: Wanpela paniman i kam na i stori long mipela.

Exercise 6: Repeat the following sentences to indicate that the actions were simultaneous. Remember to do this na and other repetitious elements are omitted. Ready?

1. Tuma i sindaun na i harim tok.

(pause)

Tuma i sindaun harim tok.

2. Masta $i$ kam sekan na $i$ toktok planti.

(pause)

Masta i kam sekan toktok planti.

3. Sampela i no lindaun na i no mekim prea wantaim.

(pause)

Sampela i no lindaun mekim prea wantaim.

4. 01 i sanap insait long haus lotu na ol i singsing.

(pause)

01 i sanap singsing insait long haus lotu.

5. Bulmakau i kirap na i pretim ol pikinini meri. Bulmakau i kirap pretim ol pikinini meri. ${ }^{l}$

(pause)

Exercise 7: Join the following sentences so as to indicate that the actions are simultaneous. You will have to use wantaim to achieve this in some sentences. Ready?

la. Subim klas i go daun!

lb. Tanim stia i go olsem!

(pause)

A: Subim klas i go daun na tanim stia i go olsem wantaim.

2a. Yu kam.

2b. Yu sanap klostu long tebol.

(pause)

A: Yu kam sanap klostu long tebol.

INote that the answer to this last sentence could also mean The bullock began to frighten the girls. 
3a. Em i skulim mi long tok ples.

3b. Em i kamautim kaukau.

(pause)

A: Em i skulim mi long tok ples na kamautim kaukau wantaim.

4a. I no gutpela tumas sapos ol i dring bia.

4b. I no gutpela tumas sapos ol i draivimka. (pause)

A: I no gutpela tumas sapos ol i dring bia na draivim ka wantaim.

5a. Skin bilongen i guria.

5b. Het bilongen i pen.

(pause)

A: Skin bilongen i guria na het bilongen i pen wantaim.

6a. 01 i sanap.

6b. 01 i krosim meri nogut tru.

(pause)

A: 01 i sanap krosim meri nogut tru.

\section{Evaluation Exercise}

Say what the following sentences mean in English.

1. Asde mi lukim sampela welpik i kam brukim banis bilong dispela gaden.

(pause)

Yesterday I saw some wild pigs come and break this garden fence.

2. I no gat wanpela man i inap sanap singautim ol manmeri

i stap nabaut nabaut i kam hariap long dispela hap.

(pause)

Nobody can stand up and call out to the population hereabouts to come here quickly.

3. Yupela toksave long ol pasin bilong mipela ol kanaka long dispela nupela masta na bihain larim em i maritim dispela meri.

You(pl.) explain our native customs to this new chum European and then let him marry this woman.

4. Sampela i sindaun kaikai pik; sampela nogat.

(pause)

some are sitting down eating pork, others are not.

5. Yu no ken ripotim mi na kalabusim mi wantaim. Yumas wet long kiap i kam harim kot pastaim.

you can't report me and lock me up at the same time.

You have to wait for the Government officer to hear

the ase first.

\subsection{SENTENCE CONNECTIVES}

Throughout this course you have had many examples of the way in which Pidgin speakers compose stories, and in particular, the way in which they use the words tasol, na, olsem na, orait na and pinis to connect ideas. Within these stories you have also had much incidental and some formal practice in the use of these, but because they are so much a part of the special flavour of Pidgin discourse this section will be devoted to further practice of them together with a less 
common one, bilong dispela on account of that, consequent $2 y$, therefore which has not been previously introduced. The only difference between this latter one and the others is that it may be preceded by na and. For example,

Dogare i laik i wokabaut long wilwil. (Na) bilong dispela em i baim wanpela long stua.

Em i krosim mi. ( $\mathrm{Na}$ ) bilong dispela mi sutim em.
Dogare wanted to ride a bicycle. (And) consequently he bought one at the store.

He got angry with me. (And) on account of that I shot him.

Before beginning the following exercises students should revise Section 9.2., "Sentence Confunction with Pinis."

Practice Drills

Exencise 1: Simple Substitution

Frame: Em i krosim mi na bilong dispela mi sutim em long banara. (ripotim em, goapim meri bilongen, kalabusim em, bagarapim marit bilongen, sutim em long banara)

Exencise 2: Change the connectives orait na, olsem na, pinis and bilong dispela in the following sentences to those given as cue. Remember, however, that when pinis is given you have to repeat the verb of the preceding sentence with 1t. Ready?

1. Wanipe i laik i go long beng. Bilong dispela em i baim bas i go.

Wanipe i laik i go long beng. Olsem na em i baim bas $i$ go.

2. Yu lesbaga yet. Olsem na yu hambak nabaut tasol.

(na bilong dispela)

Yu lesbaga yet. Na bilong dispela yu hambak nabaut tasol.

3. Em i traut. Orait na, em i go hariap long haus sik. (pinis) Em i traut. Traut pinis, em i go hariap long haus sik.

4. Kiap i kalabusim dispela dripman. Olsem na ol tambu bilongen $i$ kam bilong tanim bel bilong kiap. (na bilong dispela)

Kiap i kalabusim dispela dripman. Na bilong dispela ol tambu bilongen i kam bilong tanim bel bilong kiap.

5. Wanpela trak i pundaun long maunten. Orait na draiva i repotim dispela bagarap long plisman.

Wanpela trak i pundaun long maunten. Pundaun pinis, draiva i ripotim dispela bagarap long plisman.

Exercise 3: Join the following pairs of sentences together using the Pidgin connectives given as cues. Ready?

1a. Mi hangre nogut tru.

lb. Mi kukim rais.

(bilong dispela)

A: Mi hangre nogut tru. Bilong dispela mi kukim rais. 
2a. Asde tripela welpik i kam brukim banis bilong gaden bilong mi.

2b. Mi go painim na sutim em.

(olsem $n a$ )

A: Asde tripela welpik i kam brukim banis bilong gaden bilong mi. olsem na mi go painim na sutim em.

3a. Yu singautim ol i kam pilai kikbal.

3b. Yu winim mambu bilong kirapim pilai. (singautim pinis)

A: Yu singautim ol i kam pilai kikbal. Singautim pinis, yu winim mambu bilong kirapim pilai.

4a. Sampela skulboi i no sanap gut.

4b. Tisa i strapim em.

(na bilong dispela)

A: Sampela skulboi i no sanap gut. Na bilong dispela tisa i strapim em.

5a. Em i tok save pinis long dispela samting long mi wanpela.

5b. Mi lusim ples.

(orait na)

A: Em i toksave pinis long dispela samting long mi wanpela. Orait na mi lusim ples.

\section{Evaluation Exercise}

Add sentences to the following given sentence in the way specified. The given sentence is 01 man bilong pait $i$ kam long stesin. Again:

01 man bilong pait $i$ kam long stesin. Now here are the sentences to be added:

1. And because of that the kiap did not leave the station to go on patrol.

(pause)

A : 01 man bilong pait i kam long stesin. Na bilong dispela kiap i no lusim stesin i go wok bus.

2. Having come they began to fight.

(pause)

A: 01 man bilong pait i kam long stesin. Kam pinis, ol i kirap pait.

3. Consequently all of the European women ran away.

(pause)

A: 01 man bilong pait i kam long stesin. Na bilong dispela olgeta misis i ranewe. or

or 01 man bilong pait i kam long stesin. Olsem na olgeta misis i ranewe.

4. And they frightened the school children.

(pause)

A: 01 man bilong pait i kam long stesin na ol i pretim ol skulboi na skulmeri (or ol sumatin or ol studen).

5. But they sat down without doing anything.

(pause)

A: 01 man bilong pait $i$ kam long stesin. Tasol ol i sindaun nating. 


\section{TEXT}

Here is a story about a courtcase in Pidgin. Listen to it and then see how much of it you can transcribe and/or translate. Here is the story:

Yes mi kaunsil katahi na mi laik toktok long nau mi gat trabel long tupela meri bilong mi ol i gat kik na mi go long kot. Mi go long kot. As bilongen long nambawan meri em yet ${ }^{l}$ i kirapim trabel, kirapim trabel. Em yet i paitim nambatu meri na $i$ no gat rong, em yet. Em yet na--mi no paitim ol, mi no krosim ol, mi givimgutpela tingting bilong gavman long lo, long sindaun gut, na lukautim mi, na harim tok bilong mi na $i$ sindaun bihainim lo. Tasol ol yet i pait na kros na nau mi go long kot na mipela i go long lokal kot bipo na Lohi em $i$ laikim baim kot long distrik kot na nau mi go long distrik kot. Mi go long distrik kot, distrik kot $i$ tok $^{2}$ as bilongen (cough) mi kisim tupela meri, orait, nau $i$ gat trabel--i gat trabel, orait, ol i no laik i sindaun gut na harim tok bilong $m i$, tasol as bilong em long $m i$ yet mi kisim i kam, orait nau ol i gat trabel long dispela, arapela kik wantaim narapela, arapela kik wantaim narapela, orait nau trabel i kamap. Orait. Ating ol i ken wokim long promis, ol i ken wokim promis, na distrik kot i harim, em i tok, "Ating ol i ken wokim promis na sindaun gut na mekim wok na harim tok bilong yu man bilong em na mekim wok." Tasol mi mi tingting em i brukim lo bilong gavman, long kirapim kros o kirapim wanem trabel. Em i mekim planti trabel na mi no laikim long trabel. Olsem na nau distrik kot em i tok, "Orait, yu laik promis o i no gat." Tasol mi askim distrik kot, tok, "Mi ating mi mi no laik, mi laik rausim olgeta." Mi kam ausait, mi yet pinisim em. Mi yet pinisimem, tok, "Yu go long, yu klia nau. Mi no laikim yu nau. Mi laik lukautim em wanpela." Orait, mi rausimem, long em bagarapim mi long samting, long brukim--sutim as bilong dram, dram wara, na brukim mami, olgeta samting bilong mi em i bagarapim na mi no laikim, long em $i$ kam bek. Bai em i kam bek, tasol nogat samting bilongen long bai em $i$ kam bek na i stap na kaikai na kisim wara no wanem kain, em i bagarapim pinis. Orait em bagarapim na em i laik go we, em $i$ go. Em i tok em $i$ pinis long mi na i laik i go. Orait nau mi tok, "Orait, go nau. Mi no laik." Orait nau mi tok em i go pinis. I no inap long kam long mi moa. Em tasol nau. Tok bilong mi em tasol.

[Playing time: 4 minutes]

\footnotetext{
${ }^{1}$ otice that this speaker puts in an $i$ before yet wherever it occurs. This must be a carryover feature from his native language.

${ }^{2}$ What follows after tok is a little confused but soon clears up.
} 
ENGLISH TRANSLATION :

Yes I am councillor Katahi and I'm going to talk about the trouble I'm in with my two wives who had a disagreement/fight and (about whom) I went to court. The reason was that my first wife began the trouble. She alone fought the second wife who hadn't done anything wrong. It was she alone. She alone and--I did not hit them; I did not get angry with them. I gave them good Government advice about the law, about behaving themselves, and looking after me and listening to what I had to say and to be law-abiding citizens (lit. sit and follow the law). But they fought and got angry and so I went to court then. On the first occasion (lit. before) we went to the local court but Lohi wanted to go before the district court (lit. wanted to pay the fine in the district court) and so I went to the district court then. I went to the distriat court and was told that the reason for this (trouble) was that I had taken two wives and so there was trouble (because) they don't want to behave and listen to what I say. But the real reason why I brought them (to court) and that they are in trouble is that they fight each other and so stir up trouble. And so (I suggested) that perhaps they could make a promise (to be good). The district court heard that and said, "Perhaps they can give their word to behave (themselves) and work and obey you, the husband." But I thought she (the first wife) had broken the government law in originating the quarrel or in starting (whatever) trouble. She made plenty of trouble and I don't like trouble. So then the district court said, "Ok, are you going to promise to be good or not?" But I said to the court, "I guess I don't want (her), I want to get rid of her completely." I came outside and I (emphasis) finished her. I said, "You go to--you clear off now. I don't like you now. I want to look after only this one." And so I chased her off because she spoiled all my things; because she broke--punctured the bottom of the water drum, broke up the yams, and spoiled all my things and so I don't want her to come back. There's nothing for her to come back for, to stay, to eat, to fetch water or whatever--she's spoilt it. And now she can go wherever she likes to. She said she's finished with me and wants to go. And so I said, "All right, go now. I don't want (you to stay)." And so I am saying she's gone now. She can't come back any more. That's all now. I'm finished what I had to say.

Now to end this unit here is another Pidgin song recorded near Dreikikir, East Sepik District, 1972. It is a song which was learnt from a malaria control team visiting the area. 


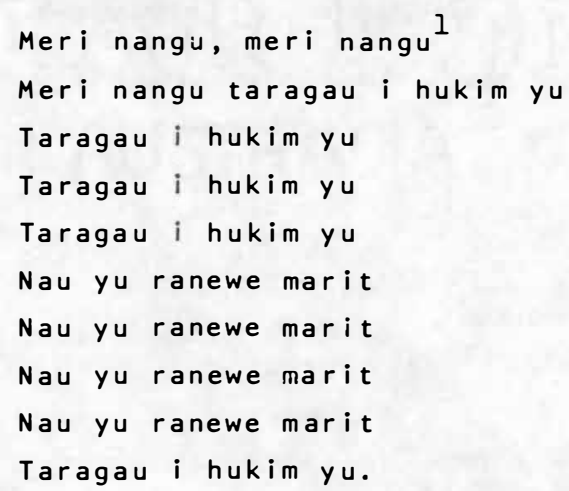

\section{SUPPLEMENTARY VOCABULARY}

trabelman/meri

trouble maker, troublesome person

man i gat kot

man i sanap long kot

winim kot

luksti lman

haus pamuk

man $i$ go i kam (long kot)

kilim bel,

rausim bel

samting bilong pasim bel

gumi bilong kok

he $\mathrm{t}$ i m

no laikim tru\}

man bilong tupela maus

promis ( i m)

brukim lo

pretman/man bilong pret

man nogut

ki Iman

brukbrukim

brukim ai

brukim han

brukim long tit

brukim namel

brukim pepa/laplap

brukim plang

brukim baret/kunai the accused

acquitted

a Peeping Tom

brothel

persistent offender

abortion

contraceptive (for females)

contraceptive (for males)

hate

hypocrite

promise

transgress a law

coward

criminal

murderer

to break into little pieces, to mash

to wink

to break one's hand; to make a (clenched) fist (as a sign of resistance)

to bite off

to break in halves; to divide in two

to tear paper, cloth

to saw timber planks from logs

to cross a stream/grassy patch

$I_{\text {nangu }}=$ sago, in the Abelam language near Maprik, East Sepik District. 
5. Correct and then answer the following advertisement that appeared

in Nation Review, Vol. 3, No. 18, February 16-22, 1973:

Wanpela Naispela man bilong Moresby

em ol meri bai seksek tru ilaikim

wanpela naispela meri igat save.

Dispela man save tok inglis tasol.

Review box 3076. 


\section{UNIT 15}

\section{CONVERSATION}

Long Lusim Mosbi

Bihain long taim Dogare i baim kot i tingting planti long lusim Mosbi

i go bek long ples bilongen.

olsem na i redim olgeta samting

bilongen na i laik givim gutbai

long Wanipe na MALOLO.

Wanipe: 0 sori brata, nau yu lusim mitupela. Yu ting wanem, bai yu kam bek gen long biktaun hia bilong painim wok o nogat?

Dogare: Nogat. Mi pinis tru long Mosbi. Mi painim, painim, painim kago longen, tasol i no gat. 0ltaim oltaim mi kisim bikpela trabel tasol. Orait na bilong dispela mi tait na mi laik i go bek long ples bilong $\mathrm{mi}$.

MALOLO: Orait, bilong yu yet, yu go. Tasol yu holim tru tok bilong mitupela. $Y u$ save, papamama bilong yu i kamap lapun pinis nau na yu mas helpim tupela i kam stap wantaim mitupela hia long Mosbi.

Dogare: Mi holim pinis. Tasol mi ting tupela lapun $i$ no laik i lusim ples kanaka i kam long biktaun.
After Dogare paid his fine to the court he thought a lot about leaving Port Moresby and returning home. So he prepared all his possessions and was on the point of saying farewezl to Wanipe and MALOLO.

Well Dogare you're about to leave us. Do you think you will return to the big smoke to seek work again or not?

No, I'm through with Port Moresby. I kept Zooking for European-type wealth but never found it. $A Z Z$ I did was to get into serious trouble. Consequently $I^{\prime} m$ fed up and I want to return home.

ok, it's up to you. But remember what we have said. Your parents have aged now so you must help them to come and stay with us here in Moresby.

I've got it. But I don't think the two oldies will want to leave their village to come to the city. 


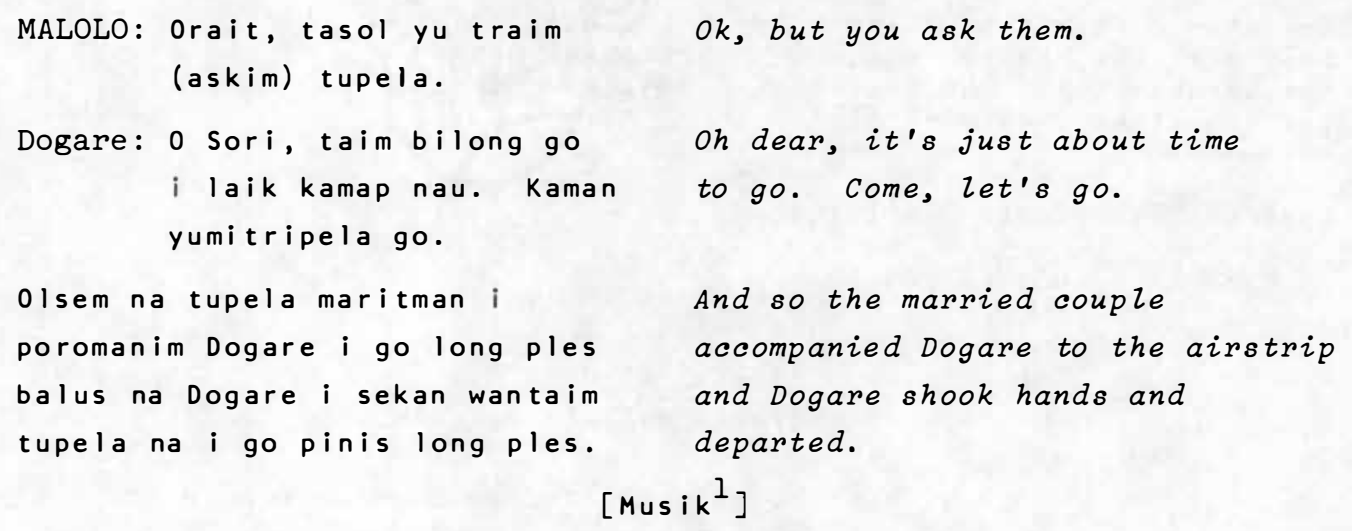

VOCABULARY EXPANSION EXERCISES

Exercise 1: Simple Substitution

Frame: Mi painim, painim, painimkago longen, tasol i no gat. pulim i kam, pulim i kam, pulim i kam,

kirapim, kirapim, kirapim,

traim, traim, traim, skulim, skulim, skulim,

singautim, singautim, singautim, painim, painim, painim kago longen,

Exercise 2: Simple Substitution

Frame: Papamama bilong yu $i$ kamap lapun pinis.

$\begin{array}{lr}\text { les } & \text { (tired, fed up) } \\ \text { kros } & \text { (angry) } \\ \text { pret } & \text { (afraid) } \\ \text { hepi } & \text { (happy) } \\ \text { lapun } & \end{array}$

\section{Exercise 3: Simple Substitution}

Frame: Taim bilong go i laik kamap nau.

wok

kamapim kantri

pasim stua

malolo

ol blakman

go (work)

(found a nation)

(close the store)

(rest)

(era of black peoples)

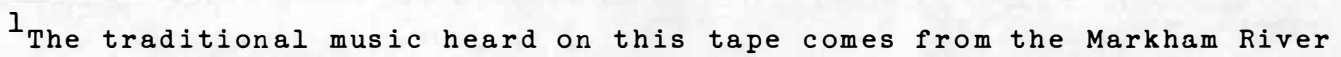
behind Lae. It is a song sung in honour of the clan ancestors. For such an occasion the dancing ground is cleared of every living plant. 
The stem of a banana palm stripped of leaves is then planted in the centre of the cleared space. The villagers sing in a circle around the banana stem. The recording comes from Sheridan (1958: side 1, track 5, item d--Gumpan Mindt).

Exercise 4: Simple Substitution

Frame: Bilong yu yet yu go.

$$
\begin{array}{lr}
\text { drip i go } & \text { (drift about) } \\
\text { kalap i go daun } & \text { (jump down) } \\
\text { prenim dispela wetskin } & \text { (befriend this } \\
\text { abrusim ol man nogut } & \text { (avoid bad men) } \\
\text { anka long Mosbi (settle in Port Moresby) } \\
\text { go }
\end{array}
$$

Exercise 5: Simple Substitution

Frame: Dogare i givim gutbai long Wanipe.

$\begin{array}{lr}\text { tok amamas long } & \begin{array}{r}\text { (give best wishes to) } \\ \text { tok isi long }\end{array} \\ \text { givimgutpela tok long (good advice, glad tidings) } \\ \text { toksave long } & \text { (inform) } \\ \text { givim baksait long } & \text { (shun, ignore) } \\ \text { tok bilas long } & \text { (mock, insult) } \\ \text { givimgutbai long } & \end{array}$

Exercise 6: Simple Substitution

Frame: Mi ting tupela lapun i no laik i lusimples kanaka. sutim tok $i$ go long (pass the word along) taitim bun bilong helpim ol long (exert themselves to help others) hol im tru tok bilong mi long (be faithful to what I have said) tekimautim gras nogut long gaden long (weed the garden) brukim dispela mani haphap long (divide the money up olgeta long between a (Z)

lusim ples kanaka

\subsection{INTENSE REPETITIOUS ACTIONS}

Actions which are concelved of as being performed over and over without any significant interruption are expressed in Pidgin by repeating the verb (or verb plus adjuncts like $i$ go or $i$ kam, or objects if these are short), or mekim (lit. do (that)) which substitutes for

${ }^{l}$ Remember isi isi $=$ slowly, carefully. 
the action described in the first part of the sentence. The result corresponds to the translation kept doing (something) in English. The following examples illustrate the common kinds of variation likely to be encountered:

Bai ol i wokim haus tambaran; wokim, wokim, wokim,
mekim, mekim, mekim,

They will keep on building the taim oi i pinisimem.

Mi wet, wet, wet, tasol trak i no kam. men's house until they finish it. I kept waiting but the truck did not come. I waited and waited but the truck did not come.

Mi wetim trak, wetim, wetim, I kept waiting for the truck but tasol em i no kam. it did not come.

Trak i go, i go, i go, orait i The truck kept going and leventukamap long Goroka. ally) arrived at Goroka.

Note that for go, $\mathrm{kam}$ and $\mathrm{stap}$ as verbs the predicative marker is generally repeated with the verb. Note also that there is no fixed number of repetitions. One varies these according to how one wants to emphasize the time span involved. Finally, variations on the above structure can be achieved by using tasol only or wok long to be busy at (doing something) with no repetitions, in a way that has already been presented. E.g.

Pikinini bilongen i krai, krai, krai tasol.

His child does nothing but cry.

Pikinini bilongen i wok long krai tasol.

His child does nothing but cry.

Practice Drills

Exercise 1: Simple Substitution

Frame: Mi wet, wet, wet, tasol trak i no kam. (sanap, slip, singaut, wok, wet)

\section{Exercise 2: Simple Substitution}

Frame: 01 i wokim haus tambaran, wokim, wokim, inap long taim ol i pinisimem.

(kaikai buai, daunim marasin, mumutim bia, wokim haus tambaran)

\section{Exercise 3: Simple Substitution}

Frame: Susa bi longen i skrapim tok, skrapim tok, skrapim tok tasol. (traim mi, haphapim wok, tanim bel, krai, skrapim tok)

Exercise 4: Change the following sentences in Pidgin into ones indicating intense repetitious action by repeating the verb, or verb plus other elements as required. Ready?

1. 01 kanaka $i$ wet, tasol kago i no kamap. ol kanaka $i$ wet, wet, wet, tasol kago i no kamap. 
2. Kila i kaunimmani, inap long taim ai bilongen i raun pinis.

Kila i kaunim mani, kaunim, kaunim, inap long taim ai bilongen i raun pinis.

3. Olgeta pikinini bilong dispela ples i pilai tasol. olgeta pikinini bilong dispela ples i pilai, pilai, pilai tasol.

4. Yupela subim ka i go inap long taim em i brukim dispela graun mal omalo. Save?

Yupela subimka i go, subim i go, subim i go, inap long taim em i brukim dispela graun malomalo. Save?

5. Hetman i krosim olgeta kanaka inap long taim kiap i kam kamap pinis.

Hetman i krosim olgeta kanaka, krosim, krosim, inap long taim k.iap i kam kamap pinis.

\section{Evaluation Exercise}

Repeat the following sentences and say what they mean in English.

1. Wanpela bikpela sik i kam, i kam, i kam daunim mipela.

A plague came and came until it (reached us) and knocked us.

2. 01 kagoboi i wok long slip tasol.

The labourers do nothing but sleep.

3. Rat i kam mumutim kaikai bilong mi, mumutim, mumutim inap long taim mi sutim em.

The rat kept coming and stealing my food secretly until I shot it.

4. Mi ritim "Wantok", ritim, ritim, inap long taim san i gondaun. $I$ read and read Wantok until the sun went down.

5. Yu bladisit, watpo yu krai, krai, krai tasol?

You nuisance, why do you do nothing but cry?

\subsection{UNSUCCESSFUL ACTIONS}

Actions which fail to accomplish their goals are indicated in Pidgin by adding tasol $i$ no gat, or tasol $i$ no ken to the end of the sentence. For example,

Mi painim, painim, painim, tasol i no gat.

Masta i mekim, mekim, mekim, tasol i no ken.
I looked and looked for it but without success.

The European tried to do it but failed.

Notice that these tags are usually used in combination with intense repetitious actions just described in Section 15.1 above. Notice also that for some sentences the English translation of tried to do something but failed is acceptable. 
Practice Drills

\section{Exercise 1: Simple Substitution}

Frame: Mi raunim pik, raunim, raunim, tasol i no gat.

(winim mambu, kirapim ensin, opim tin, kukim kunai, raunim pik)

\section{Exercise 2: Simple Substitution}

Frame: Masta bilong Amerika i lainim tokples, lainim, lainim, tasol i no ken.

(sutim banara, sanapim diwai, brukim haiwara, kalabusim muruk, lainim tokples)

Exercise 3: Answer the following questions indicating that someone tried to do what was asked or kept doing what was asked but without success. In your answer you need only repeat the verb, anything else will be regarded as understood from the question. For example, if the instructor were to ask: Yu klinim haus lotu pinis? your answer should be: Mi klinim, klinim, klinim, tasol i no gat. I tried to clean it but without success. In the following use gat instead of ken in your answers. Ready?

1. Q: Yu singautim kukboi i kam?

(pause)

A: Mi singautim, singautim, singautim, tasol i no gat.

2. $Q: 01$ i givim trausis longen?

(pause)

A: 01 i givim, givim, givim, tasol i no gat.

3. Q: Yu tupela i painim kago pinis longen? (pause)

A: Mi tupela i painim, painim, painim, tasol i no gat.

4. Q: 01 i prenim pinis dispela wetman yu tok longen?

(pause)

A: 01 i prenim, prenim, prenim, tasol i no gat.

5. Q: Em i abrusim ol man nogut?

(pause)

A: Em i abrusim, abrusim, abrusim, tasol i no gat.

\section{Evaluation Exercise}

Say what the following sentences mean in English.

1. Kalabusman i traim ranawe tasol i no ken.

The prisoner tried to escape but couldn't.

2. Mama bilongen i laik i kirapim wok tasol i no gat.

His mother wanted to start work but couldn't.

3. Mi raitim pas, raitim, raitim, tasol i no stret.

I tried to write a letter but it wasn't right. 
4. Em i traim hangamapim bilum tasol em i no inap; hangamapim, i pundaun; hangamapim, i pundaun; hangamapim, i pundaun.

He tried to hang up the string bag but he couldn't; every time he did it fell down.

5. 01 i sekan, sekan, sekan inap long taim ol han i dai. They shook hands until their hands were numb.

\subsection{TO BECOME: kamap}

The most ccmmon way of expressing to become in Pidgin is by using the verb kamap.l For example:

Pikinini bilong mi i kamap dokta nau.

My child is becoming a doctor now.

Pikinini bilong mi i kamap bikpela nau.

My child is getting big now.

Pikinini bilong mi i kamap

strongpela nau.

My child is getting strong now.

Practice Drills

Exercise 1: Simple Substitution

Frame: Pikinini bilong mi i kamap dokta nau.

(bikpela, strongpela, liklik, didiman, les, dokta)

Exercise 2: Repeat the following sentences substituting the cues given:

1. Meri bilongen i no kamap sik yet.

( papa)

Papa bilongen i no kamap sik yet.

2. Taim sit bilong paia i kamap blakpela yu putim em long skin kamban.

(wetpela)

Taim sit bilong paia i kamap wetpela yu putim

em long skin kamban.

3. Ating bai mi skul long kamap kiap long naintin seventi foa.

( $t$ is a )

Ating bai mi skul long kamap tisa long naintin seventi foa.

4. Yupela i stap we na yupela i kamap sik?

(hangre)

Yupela i stap we na yupela i kamap hangre.

5. Long wanem taim em i kamap luluai?

$(t u l t u l)$

Long wanem taim em i kamap tultul?

${ }^{1}$ Save and laik may also be used for become but their use is more restricted and will not be drilled in this course. See Mihalic (1971: 33; 118 ). 


\section{Evaluation Exercise}

How would you say the following things in Pidgin?

1. I was very frightened when I got sick.

Taim mi kamap sik mi pret nogut tru.

2. Nobody used to become chief in our society.

Bipo i no gat wanpela man i save kamap hetman o namba wan man long olgeta lain bilong mipela.

3. These two young snakes wizl become water-spirits.

Dispela tupela yangpela snek bai i kamap masalai.

4. Don't force your child to become a teacher!

Maski duim pikinini bilong yu i kamap tisa.

5. Let your child become what $H E$ (emphasis) wants to.

Larim pikinini bilong yu i kamap wanpela samting em yet

i laikim em.

6. I washed and washed but my skin did not become clean.

Mi waswas, waswas, waswas tasol skin bilong $m i$ no kamap klinpela.

\subsection{ABOUT TO: laik V}

Actions which are about to take place or are on the verge of taking place are expressed in Pidgin by placing laik before the verb without the predicative marker i.l For example:

San i laik gondaun nau.

Hariap, paia i laik dai.

Maski, ren i laik pinis nau.
The sun is about to set now.

Quickly, the fire's just about out.

Never mind, the rain is on the

verge of stopping.

Note that this construction is to be contrasted with laik plus the predicative marker i used to express wish or desire which was presented in Unit 2, Section 2.3. The distinction is not always made, however, in some areas, and anyway cannot be for the verbs $\mathbf{i}$ go, i kam and i stap. For example:

01 i laik i go nau.

They want to/are about to go now.

Practice Drills

Exercise 1: Simple Substitution

Frame: 01 i laik lap nau.

(smok, sekan, dring ti, kisim pe, nildaun, lap)

${ }^{1}$ See footnote for section 2.2 above concerning the use of this form and laik i. 
Exercise 2: Change the following sentences from ones expressing a desire to do something to ones expressing the idea that the action is about to take place by omitting the predicative marker i. Ready?

1. Tupela lain kanaka bilong Kandep i laik (i) pait.

(pause)

2. I gat planti meri i laik (i) kamap tisa.

(pause)

3. Husat i laik (i) draivim ka bilong kampani bilong yumi? (pause)

4. Bilong wanem ol i laik (i) planim kopi?

(pause)

5. Taim welpik i laik (i) ranawe yu sutim em!

(pause)

\section{Evaluation Exercises}

Exercise 1: Say what the following things mean in Pidgin. Be prepared for the differences between laik, laik $i$ and laikim. Ready?

1. Mi no laikim susu.

(pause)

I dor't like milk.

2. 01 i laik i kamapim kantri hariap.

(pause)

They want to found a nation quickly.

3. Ol dispela pikinini i laik daunim marasin hia, em ol i bilong mi.

(pause)

These children who are about to take this medicine are mine.

4. Maski enl i laikim sutlam bilong mi tasol em i no ken kisim en.

(pause)

Even though he likes my torch he can't have it.

5. Lukim! Smokbalus i laik kirap flai nau.

(pause)

Look, the jet plane is about to take off now (lit. begin to $f(y)$.

Exercise 2: Fut your machine on "Record" and see how well you can express the following sentences in Pidgin:

1. The men are now about to set a date for the collection (pause) of taxes.

01 man i laik makim de bilong kisim takis nau.

2. Why do you want to cook the cassowary in a mumu?

(pause)

Bilong wanem yu laik i mumuim muruk?

3. Look out:! The tree is on the verge of falling.

(pause)

Lukaut! Diwai i laik pundaun.

4. My sore is about to heal up now.

(pause)

Sua bilong mi i laik drai nau.

5. What the hell did you want to burn the grass for?

(pause)

Watpo yu laik i kukim kunai?

Wasmara yu laik i kukim kunai? 
TEXT

Listen to the following incomplete story about how some councillors came to Dreikikir in the rain one time, and then transcribe and/or translate it. Here is the text.

Nem bilong mi Yosef Nokomdia. Mi bilong ples Masalagar, liklik ples Elkelmala (?). Asde mipela i bin kirap wantaim kaunsil bilong mi Labundagri (?) na ol arapela lain bilong ples bilong mi. Mipela $i$ laik kam long Dreikikir i gat bikpela ren long moning long hap bilong mipela long Masalagar. Orait mipela i slip i stap i stap i stap inap samting olsem ten klok mipela i kirap. Mipela i kirap wokabaut i kam i kam i kam i kam i kam i kam kamap lusimbus bilong yumi nau mipela kamap long bus bilong Duaituk, mipela i bin sindaun malolo, mipela i kukim liklik samting, mipela kaikai wantaim saksak, sampela kiau bilongwelpaul, na wanpela liklik mumut, na mi sutim wanpela balus tu. Mipela kukim na kaikai wantaim saksak bilong rot long hap bus bilong Duaituk. Em samting olsem hap pas foa mipela i bin kirap wokabaut kamap long ples Duaituk em faiv klok pinis. Orait mipela lusim ples Duaituk mipela i kam daun i kam kamap long wanpela liklik ples bilong ol Tau i stap, long bihain ol i kolim Karkasi. Mipela i kamap long dispela hap em i hap pas sikis pinis. Orait mipela i sindaun, kisim win, na kaunsil wantaim komiti ol i toktok long slip long dispela ples. 01 i karim paiawut wantaim. 01 i brukim draipela draipela paiawut. 01 i kamap ol i laik slip long dispela ples na mi tok, "Sori, i no taim nogut. Em i gutpela taim inap long mipela wokabaut na kamap long ples Tau. Mipela i ken slip long ples Tau. Em isi. Sapos yumi i slip hia nau yumi kirap wokabaut i go gen em i longwe tumas." Orait planti ol i laik slip na sampela bilong yumi i tok, "Sori, plis, mobeta yumi muvap ${ }^{2}$ long bikples na yumi slip." Orait yumi kirap na wokabaut, yumi laitim wanpela lam, na yumi bin wokabaut kisim sampela lip kokonas, drai lip ${ }^{3}$ kokonas, em dispela em i lam bilong mipela ol tumbuna bilong bipo long hap long Niu Gini, mipela i save laitim nau wokabaut. Mipela holim dispela wantaim lam mipela i wokabaut i kam i kam i kam i kam i kam i kam, kamap long ples Tau, nambatu Tau. Orait mipela kamap mipela putim samting long haus bilong wanpela man long Tau--man bilongen $i$ go pinis na meri tasol i bin sindaun i stap, mipela i kamap. Em i bin sori long mipela nait em $i$ kukim taro. Em i kukim wanpela taro sospen, yumi kaikai pinis em $i$ givim haus bilongen long mipela na mipela i slip. I go tulait, kirap, samting olsem hap pas sikis samting, mipela--ah, sikis klok samting mipela i bin lusim ples Tau, nambatu Tau--nem bilong ples mipela slip longen, Bori. Orait mipela wokabaut i kam bungim sampela lain man lohap bilong mipela yet long Kowangal (?) na lohap bilong Bongos, na [footnotes overleaf] [continued overleaf] 
Wasambu, Bongonati, Mansi, ol i kin slip long haus kiap long namba wan Tau--ples oli kolim Warememu. Mipela i kamap bungim ol yumi putim lain na wokabaut wantaim. Mipela foa lain olgeta i kam i kam i kam i kam daun long wara. Olgeta i kam daun putim samting, yumi sindaun malolo na waswas, wasim ol dres bilong yumi, sevim gras na mipela i-sampela mipela i kam pas na sampela ol i sindaun na kukim kaikai yet. Bilong wanem mi gat toktok long sotgan ${ }^{4}$ bilong mi mi bin i go trenin longhap bilong Maiwara long tupela yia long Katitikel ${ }^{5}$ trenim long hap Maiwara long Madang Distrik. Orait kiap i wokabaut long 1972 i raun long ples bilong mi na sotgan bilong mi $i$ stap long haus bilong kaunsil bilong mi. Mi no...

\section{[Playing time: 3.5 minutes]}

\section{ENGLISH TRANSLATION :}

My name is Yosef Nokomdia. I'm from Masalagar vizlage, the section (called) Elkelmala (?). Yesterday we started off with our councillor Labundagri (?) and other groups from my village. We were about to come to Dreikikir (but) there was heavy rain in the morning in our area around Masalagar. So we slept/lay about until about ten o'clock before starting. We started and kept coming until we left our bush behind and passed into that of the Duaituk (where) we had a rest and cooked a bite to eat (lit. something small) and ate it with sago, some bush-turkey eggs, and a small bandicoot. I shot a pigeon as well. We cooked and ate it with sago we'd brought for the journey in part of the Duaituk bush. It was about half-past four when we started off (again) and was five o'clock when we arrived at Duaituk. And so we left Duaituk and came down and arrived at a small village of the Tau (which) they said later was Karkasi. When we arrived there it was past half past six. We sat down and had a spell and the councillor and committee men talked about sleeping in that place. They gathered firewood and broke up a huge amount of it. They were about to sleep there and I spoke up, "I disagree, the weather's not bad. It's good enough for us to get to Tau village. We can sleep there. That's easy. If we sleep here then when we start off again it'll be much

\footnotetext{
${ }^{1}$ saksak bilong $r o t=$ sago we'd brought for the journey (lit. sago for the road).

$2_{\text {muvap }}=$ move up, go on to (concept of "up" is towards Dreikikir).

3 drai lip = draipela lip = dry leaf.

4 sotgan = normally masket (bikmaus) shot gun

${ }^{5}$ Katitikel trenin $=$ Catechist training (?).
} 
further." Many were about to/wanted to sleep but some said, "Yes, it would be better if we went on to the main centre and slept." And so we walked on. We lit a torch. We got some coconut fronds--dry fronds --and lit them and walked on. These torches were the lamps of our ancestors in New Guinea. We held these and lamps and came until we arrived at Tau, the second Tau. Having arrived we put our things in the house of a man from there--(actually) the man of the house was away and only the woman was there when we arrived. She was sorry for us and during the night cooked us some taro. She cooked us a saucepan full of taro and after we'd eaten she gave us (run of) the house and we slept. At daybreak we got up at something like half-past six--ah, about six o'clock and we left Tau, the second Tau. The name of the place where we slept was Bori. And so we came and then met some of our own area villagers at Kowangal (?), and some from Bongos, and Wasambu, Bongomati, Mansi--they had slept in the rest house at the first Tau--the place called Warememu. We met and came on together in a line. There were four lines all told. We kept coming until we reached the river; they all came down, put their things (on the ground), sat down, bathed, washed clothes, shaved and then we--some of us came on first/ahead and some sat and cooked food. (I came on) because I had something to say about my shotgun. I had gone for two years Catechist training at Maiwara in the Madang District and when the kiap had patrolled through my village my shotgun was in the councillor's house.

Now to end this unit here is a recording of the National Day song.

\section{SUPPLEMENTARY VOCABULARY}

kantri
ileksen
ilektim
Haus Asembli
independens
memba
mosen
go het
polisi/as tok
duim
vot
kisim ples bilongen
i gat planti moa spes
bilongen

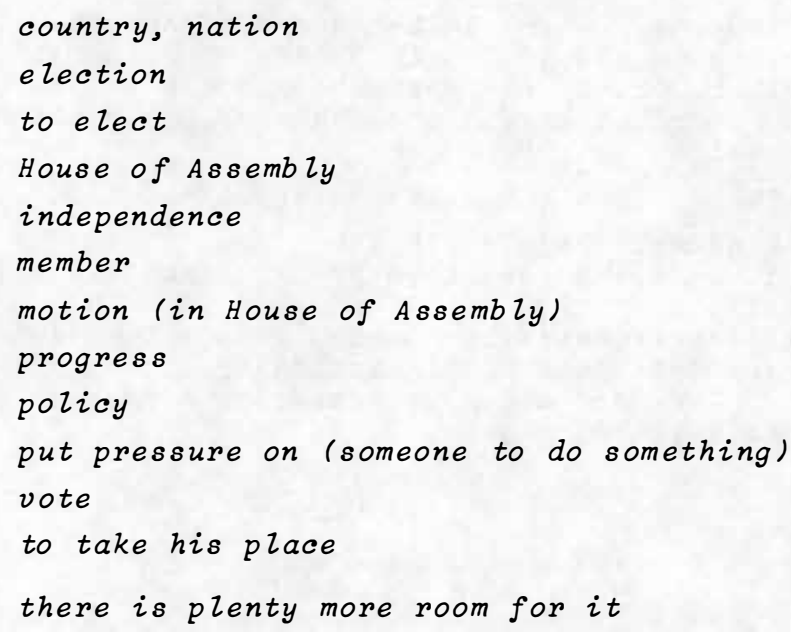




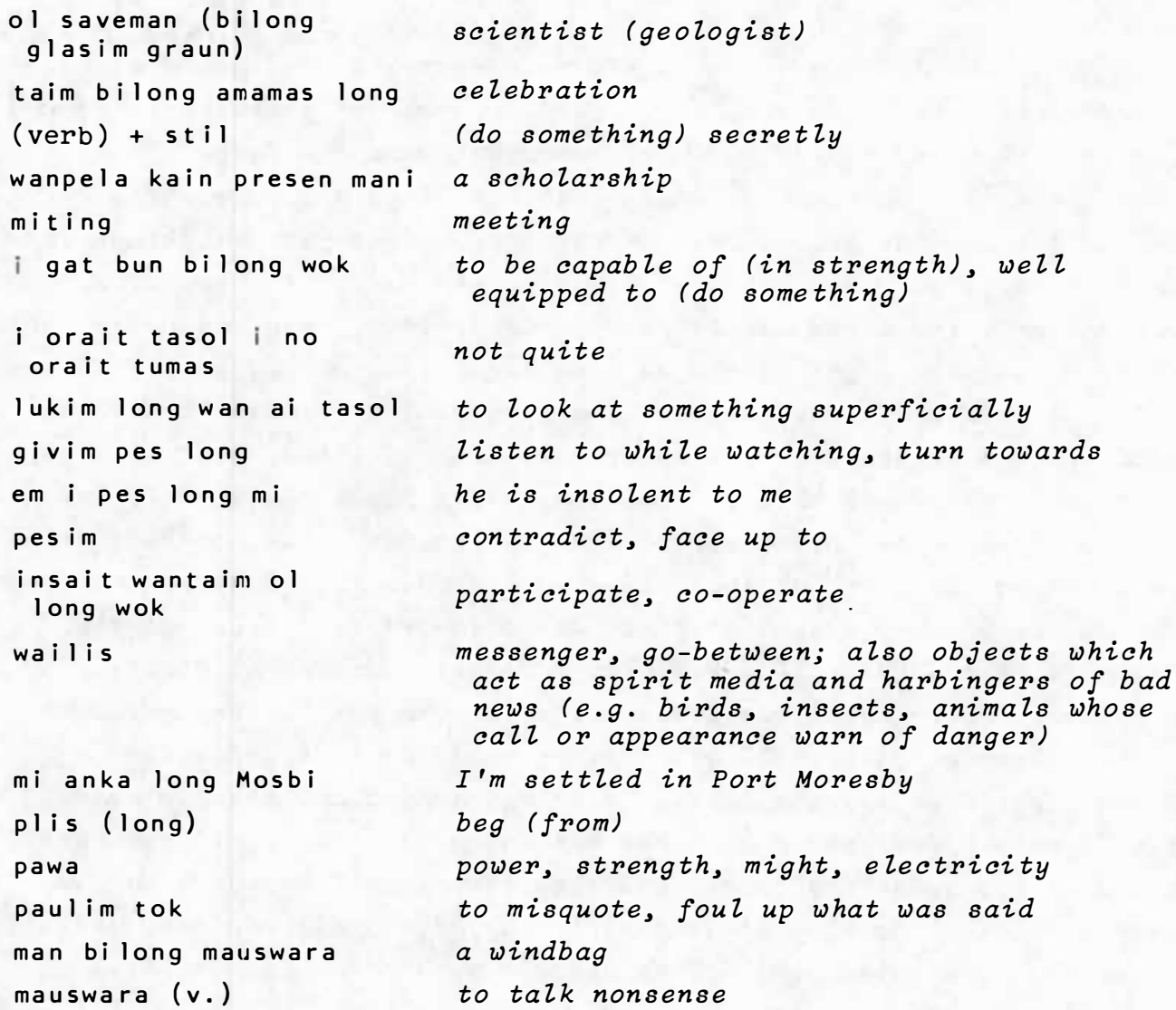

\section{CLASSROOM EXERCISES}

1. Listen to Unit 16 and discuss (1) some differences between the texts there and what you have been taught in this course, and (11) the difference between New Guinea Pidgin and Bichlamar.

2. Pretend you are in the House of Assembly in Port Moresby and have a class debate in Pidgin on say: Should Papua New Guinea become a nuclear power'? At least one student should be chosen to act as interpreter and give a simultaneous translation in English to those not participating.

3. Puppet Show. Revise conversations 1-15 with glove puppets.

4. Reading. Pidgin Plays:

1. Em Rod Bilong Kago by Leo Hannet (published in Kovave, Vol. I, No. 1);

11. Manki Masta by Kumalau Tawali (published in Five New Guinea

Plays (Brisbane: The Jacaranda Press, 1971);

111. The Good Woman of Konedobu, A Play by Rabbie Namaliu (published in Kovave, Vol. 1, No. 2). 


\section{SUPPLEMENTARY MATERIAL}

This unit is solely a listening unit. It is designed to acquaint the learner/speaker of New Guinea Pidgin with some of the regional variation that he is likely to encounter within New Guinea Pidgin as well as with some of the differences between this pidgin and its relatives spoken in neighbouring areas of the Pacific.

The unit consists of a number of texts recorded by speakers from different parts of Papua New Guinea, the Solomon Islands and the New Hebrides. These texts are presented in two sections and each is accompanied by transcriptions and notes. However, the student would do well not to consult these until after he has made his own attempt to transcribe and translate the texts and to note down some of the differences he hears from what he has been taught in the preceding units of this course. In Section 16.2 some references are also given for those wishing to study the Solomon Islands and New Hebridean Pidgins further.

\subsection{ILLUSTRATIVE TEXTS FROM ACROSS NEW GUINEA}

This section consists of texts recorded from the principal Pidginspeaking areas of Papua New Guinea. Although they do not represent the complete range of variation between speakers from area to area (or within any one area for that matter) they are sufficient to illustrate the kinds of differences that exist and which the learner/ speaker must be prepared to adjust to. In general these differences are quite minor resulting mainly from interference from the speaker's own mother tongue and/or from regional preferences for saying some things in one way rather than another. Some of these preferences have already been pointed out in the earlier units of this course.

\section{TEXT 1}

Tupela Brata. A traditional tale told by Kiu Sialis ( $f$, about 20 years), a Kate speaker from Finchafen, Morobe District, New Guinea. This text was recorded by Dr. A. J. Taylor, Translation Consultant, British and Foreign Bible Society, Lae, New Guinea in December, 1972. Here is the text:

Long wanpela taim wanpela lapun meri wantaim pikinini--tupela pikinini man bilong em ol i stap. 01 i stap klostu long wanpela wara i ran stret long arere bilong nambis. Na olgeta de dispela lapun meri i save stapim tupela liklik pikinini bilong em long no ken bihainim wara. Nogut tupela i kisim bagarap. Na long wanpela de bikpela brata bilong dispela liklik boi i tok, "Bilong wanem tumbu na bilong mitupela i stapim mitupela long wokabaut nabaut?" Na long moningtaim 
tru tupela i kirap na i wokabaut i go bihainim wara i go antap long het bilong em. Taim tupela i wokabaut i go tupela i lukim planti pis na tupela i wok long sutim pis. Taim tupela i go antap tupela i lusim tingting olgeta long haus bilong tupela. Na tupela i bihainim wara i go antap long bikbus. Nau tupela i lusim rot bilong i go bek long haus. Taim tupela i kamap long wanpela diwai tupela i hangre nogut tru. Na tupela i sindaun ananit long wanpela ton tri i gat kaikai bilong em. Nau bikpela ren i kamap na san i laik go daun na ren tu i kam daun. Tupela i sindaun na tupela i nogat paia bilong kukim kaikai. olsem na tupela i lusim pis i stap long klostu long wara na tupela i go sindaun ananit long ton tri na lukluk long kaikai bilong em. Taim tupela i lukim kaikai bilong ton i slip i go daun long wara tupela i ting olsem, ton i sanap antap long diwai. Tasol dispela ton i mau na piksabilong em i go kamap long wara. Taim tupela i lukim tupela i ting bai tupela i holim na--no--nogat. Tupela i kalap i go daun long wara long holim ton--kaikai bilong ton, na taim tupela i go daun dispela piksa bilong ton i ranewe. Tupela i wok long wokim olsem tasol, na bikpela brata bilong em i kros tru. Taim tupela i kam antap bek tupela i sindaun tasol. Nau tudak i kamap, na bikpela ren i kamdaun. Na liklik brata bilong em i hangre tru na i tok, "Bai mitupela i wokim wanem?" Na i krai. Na bikpela brata bilong em i tok, "Yu kam sindaun long bek bilong mi na bai mi karim yu." 01 sem na liklik bratabilong em i sindaun long baksait bilong bikpela brata na brata bilong em i karim em na tupela i sindaun. Taim tupela i sindaun liklik brata bilong em i dai long antap long baksait long bratabilong em. Na tupela i sindaun ì go na ren i laik pinis na bikpela brata bilong em i kirapim liklik brata na i tok, "kirap na mitupela i go long haus." Tasol liklik brata i no toktok, long wanem em i dai pinis. Nau em kirap, na i karim liklik brata bilong em i dai pinis na i wokabaut i go kamap long ples. Taim em i go kamap long ples tumbuna bilong em i lukim tupela na i kisim tupela na i tokim--askim tupela, "Yutupela i go we?" Na tumbuna bilong tu--tupela i krosim bikpela brata bilong em na i rausim dispela liklik boi i dai pinis long baksait bilong brata bilong em. Em tasol. 1

[Playing time: 4 minutes]

\footnotetext{
${ }^{l}$ Note that this speaker uses trilled $r^{\prime} s$ where others generally use flapped ones and that because this speaker is well educated she sometimes uses Enerlish words for the Pidgin counterparts that have been presented in this course, e.g. bek for baksait back, boi for manki boy.
} 


\section{TEXT 2}

Pukpuk em i olsem Tumbuna Bilong Mipela. A traditional tale told by Ujan Talil (m) from Madang. This tale was recorded by Dr. A. J. Taylor, Translation Consultant, British and Foreign Bible Society, Lae, New Guinea, in December 1972. Here is the text:

Dispela em i wanpela liklik stori mi laik mekim. Em i stori bilong ol tumbuna bilong mi. Olsem ol lain famili bilong mi $i$ kam longen. Nau dispela stori em i olsem.

Wanpela lapun tumbuna bilong mipela em i bin karim planti pikinini i go na las pikinini bilongen em i karim wanpela pukpuk. Na dispela pukpuk taim em i liklik yet em i stap wantaim ol mamapapabilongen long haus bilong ol. Na dispela pukpuk em i kamap olsem wanpela pren bilong ol na em i save raun wantaim ol liklik pikinini long ples, na ol i save pilai, na ol i save waswas wantaim long nambis, na olgeta samting. Tasol bihain em i bikpela, na em i save mekim wanpela samting. Em i save gostilim pik bilong ol arapela ples i kam, na, ol i kukim dispela pik, em oltaim save laikim kaikai lewa bilong pik. olsem nau na oltaim em i kisimpik i kamol i katim na kukim ol i save givim lewa bilong pik long mama bilongen na em i kukim na dispela pukpuk i save kaikai. Tasol wanpela taim em i gokisim wanpela pik i kam na ol man bilong ples ol i tok, "Em tasol oltaim i save kaikai lewa bilong pik na yumi save kaikai mit tasol. Nau bai yumi givimem mit bilong pik na bai yumi kaikai lewa bilong pik." olsem nau nalol i no givim lewa bilong pik longen. 01 i givim wanpela hap mit bilong pik long mama bilongen na em i kukim, na i givim long dispela pukpuk. Dispela pukpuk em i lukim dispela mit bilong pik na em i no laik kaikai. Bel bilongen nogut na em i slip i stap. olsem nau na long wanpela taim ol man olgeta ol i go long ol man i save stap long bus long ol i laik senisim samting bilong ol. 0lsem ol man bilong antap ol i save kisim kaikai bilong ol i kam daun na ol man bilong nambis i kisimpis i go antap na ol i senisim dispela i olsem bisnis bilong ol. olsem na long dispela taim ol i laik igo na ol i lusim olgeta pikinini bilong ol i stap long ples. Na dispela pukpuk em kros bilong em i stap long ol i no givim em dispela lewa bilong pik. olsem nau na taim ol man i go pinis em i kirap na i go daun wantaim ol pikinini long nambis na em i kilim dispela olgeta pikinini na em i brukim bel bilong ol na ol ${ }^{2}$ i sta--tromwe ol i stap long nambis na sampela antap long ples. Em i mekim ol olsem na ol pik nabaut tu em i mekim olsem

\footnotetext{
${ }^{I}$ ote that this speaker uses olsem nau na where others use olsem na. 201 should be em.
} 
nau ol--olgeta kainkain animal i stap long ples tu em i mekim olsem. Na bihain ol man i kam bek gen long ples na ol i lukim samting olsem olgeta bel bilong ol i bruk tru. 01 i kros nogut tru na ol i--ol i tok bai ol i kilim dispela pukpuk. Olsem nau na long pasin bilong ol man sapos ol i laik singautim arapela lain i kam na ol i laik kilim dispela--ah, kilim dispela pukpuk. Olsem nau na ol i redim olgeta samting. 01 i pasim ol buai, na redim i stap, na kaikai na kain samting olsem. Na ol i singautim ol arapela ples bilong i kam na kilim dispela pukpuk. Taim ol dispela man i kamap ol i laik kilim dispela pukpuk, na dispela pukpuk i no pret. Em i no ranewe. Nogat. Em i slip long haus bilong papa bilongen $i$ stap. Em $i$ gat wanpela liklik bet ol i wokim bilongen. Olsem nau na em i save slip long dispela. Em i slip i stap nau man bilong pait i kamap. 01 i kam nau ol i laik pait long dispela pukpuk. Ol i kisim spia bilong sutim dispela pukpuk. i kam. Na man i go pas long pait em i nambawan man bilong tromwe spia. Sapos em i tromwe spia i no inap abrusim wanpela samting. Olsem nau na dispela man i go pas. Em i go tromwe spia long sutim dispela pukpuk tasol dispela pukpuk $i$ no ranewe. Em $i$ saitim--sait bilongen tasol na spia bilong dispela man i go sutim nating bet. Na planti spia ol i tromwe long sutimem tasol ol i no sutim dispela pukpuk, em $i$ wok long saitim bodi bilongen tasol na ol i wok long abrusimem yet. 01 sem na mama bilongen i krai yet na kirap nau tokim dispela pukpuk, "Asua bilong yu yet na ol i laik kilim yu nau. Yu kirap na yu go daun." Olsem na dispela pukpuk i kirap isi isi tasol wokabaut i go daun. Em i go daun long graun nau em i no ran. Em i wokabaut isi isi tasol i laik go daun long solwara na em i wokabaut i go. Tasol ol dispela man bilong pait ol i kam klostu tru ol i sut--ol i tromwe spia bilong ol long sutim dispela pukpuk tasol em i saitim bodi bilongen tasol nau ol i abrusim em nau sutim graun nating. 01 i mekim olsem yet, i--na dispela pukpuk $i$ wokabaut $i$ go $i$ go na $i$ go daun long nambis. Em $i$ go daun na em $i$ swim $i$ go na $i$ go kamap long wanpela $r i p$ na em $i$ sanap long tel bilongen na em $i$ singaut i kam bek long dispela ol man ol i laik pait longen na i tok, "olgeta samting bilong yupela, yupela was gut. Sapos ol i--ol dispela samting i kam daun long solwara em bai i bilong mi. 0 sapos yupela laikim ol samting bilong yupela i stap, yupela was gut na ol i stap antap." Olsem na dispela em i olsem namba wan taim bilong em bilong toktok na em i swimgen na i go daun, i go olgeta. Olsem nau na long b--dispela taim em yet bipo tu em i bin kilim planti ol pik nabaut na ol kainkain samting bilong ol man, tasol nau em i no moa mekim dispela pasin. Tasol em i no kisim ol samting bilong ol lain bilong em yet. Em i save kisim ol samting bilong ol arapela man em i olsem birua 
bilong mipela. Em, em i save kisim ol samting bilong ol. Tasol nau, em i no moa pait em i stap isi tasol. Na dispela pukpuk em i stap yet. Olsem nau na long ol lain tumbuna bilong mipela na lain bilong mi mipela i ting long pukpuk em i olsem tumbuna bilong mipela. Na dispela olpela bilip i stap yet na mama bilong mi yet em i stori long dispela stori. Em tasol.

[Playing time: 7 minutes]

\section{TEXT 3}

Pikinini Bilong Snek by Kwingu, an Arapesh speaker from Ilahita village in the East Sepik District, New Guinea. This text was recorded in 1970 by Mr. Don Tuzin, Research Scholar, A.N.U. Here is the text:

Orait na mi (?) na mi laik stori long sampela samting gen. Olsem wanpela man i bin maritim wanpela meri. Na dispela meri i no save karim pikinini, nogat. oltaim tupela i pilai na dispela meri i save go pispis long as bilong mambu.

I go $i$ go na dispela snek $i$ slip long as bilong mambu $i$ wok long daunim pispis bilong meri. I go i go na bihain dispela snek i gat bel. I gat bel nau na i bin karim wanpela pikinini.

orait na bihain dispela meri i laik go nau long pispis gen na harim pikinini i wok long krai. Tok: "pikinini bilong husat i krai." Em i laik rausim gras na i lukim snek hia holim pas long pikinini na tupela i slip i stap. Stap nau, orait bihain meri i go holim pikinini karim i kam nau na snek tu i wokabaut $i$ kam.

l go i go nau na meri wokim bet bilong pikinini, ah--pikinini i slip na pit--ah--snek i slip na pikinini $i$ antap long snek, wanpela snek. Orait, na tupela i slip. Orait, oltaim na dispela snek i save givim susu long pikinini yet. Orait na bihain, mama i hatwok bilong em long kisim wara na wasimpikinini. I go i go na pikinini i laik bikpela nau, orait mama i holim dispela (2) pikinini nau, tok: "orait, yu snek bai yu go i stap arere." Orait snek i go i staparere.

Orait, bihain mama yet i hatwok long kisim gutpela kaikai. kisim ol prut i gat susu. Em i wokim na susu bilongen i gat (?) susu nau, orait bihain dispela pikinini em i dring susu bilong man.

Na snek $i$ go i stap arere nau. I go i go na bihain dispela man $i$ kamap bikpela nau na snek i go i stap arere. I no lusim tupela.

Em tasol. I no longpela tumas.

[Playing time: $1^{\frac{3}{4}}$ minutes] 


\section{TEXT 4}

Asa na Elu by DRI from Manus Island. This story was recorded in 1960 by Dri at Okapa in the Eastern Highlands where he was serving as a policeman. Here is the story:

Orait dispela stori bilong tupela meri. Nem bilong tupela Asa na Elu. Tupela i stap long wanpela ples. Orait dispela ples nem bilongen Tuyang. Taim tupela i stap na tupela yet i tok, "Mitupela i bombom ${ }^{1}$ long wara." Orait tupela i karim ol mambu olgeta samting bilong bombom long wara. Tupela i go daun long tupela wara i bung. Orait taim tupela i go stap long wara tupela i dilim tupela. Wanpela i go long narapela waranembilongen Wurei, na wanpela i go long wara-narapela wara nem bilongen Tinui. Taim tupela i go orait Asa i go long Tinui na Elu i go long Wurei. Orait taim tupela i go narapela $i$ no save long rarapela. Orait Asa $i$ go i painim wanpela pikinini bilong masalai. Em i bikpela masalai tasol i tanim em long liklik pikinini na i sindaun long ston na $i$ wok long krai olsem liklik pikinini ol i karim nupela. Orait taim Asa i go i lukim dispela pikinini na i ting, "pikinini bilong wanpela man." Orait na em $i$ kisim dispela pikinini i karim. Taim em i bombom long wara i kilim maleo na pis, kindam i givim long han bilong dispela pikinini na em i masalai em i kaikai dispela olgeta samting na em $i$ tromwe het bilongen long wara na Asa i askim, "Wanem samting i gat pikinini?" $\mathrm{Na}$ em i tok, "Nogat, em ol liklik ston mi sindaun mi kisim na mi putim long han bilong mi na mi wok long tromwe long wara." Taim dispela i go tulait tupela $i$ kam bek bung long ples bilong tupela. Tupela $i$ kaunim olgeta kindam na pis na maleo. Bilong Asa i no planti, na bilong Elu i planti moa. Orait nau ol i stapol i kukim dispela ol kaikai. Orait ol i kaikai. Taim ol i kaikai pinis dispela pikinini bilong masalai em i tok olsem, "Tupela mama mi laik pekpek." Orait mama bilong tu--bilong em $i$ tok olsem, "Yu go pekpek long sithaus." Na em i tok, "Mi no laik go long sithaus." Na tupela i tok olsem, "Yu go long han bilong dispela ton ${ }^{2}$." Na em i tok, "Mi no laik go long dispela." Tupela i tok, "Yu go long han bilong kalabulin 3 ." Na em i tok, "Mi no laik." Tupela i tok, "Yu go long as bilong

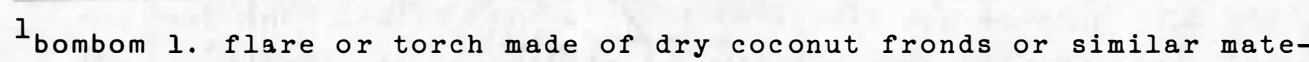
rial, e.g. laitim bombom to light a flare; 2. to spear fish at night by the light of such flares, e.g. mipela i go bombom we are going spear fishing at night. (This is generally done when there is low tide and no moon. The fish are believed to sleep at this time.)

${ }^{2}$ ton $=a$ tree with edible fruit (Pometia pinnata) but also good for timber.

3 kalapulin, kalopilum $=$ the callophyllum tree (Calophyllum inophyllum) 
fikus ${ }^{1}$." Em i tok, "Em. Mi laik go long dispela."

Taim em i pekpek pinis wanpela welpik i kam kaikai pekpek bilongen. Orait. Em i singaut long mama bilongen, "Wanpela samting i kaikai pekpek bilong mi." Tupela mama bilongen $i$ tok, "Ating mumut." Em $i$ tok, "I no mumut." Tupela i tok, "Ating rat." Em i tok, "Nogat." Tupela i tok, "Ating welpik." Em i tok, "Em." Orait em i singautim, "Yutupela i kam yumi kilim. Tupela i no yet em i kilim dispela pik pinis. Em i tok. "Yupela i kam yumi karim." Tupela i no yet em $i$ karim i go putim long ples. Taimem i go putim long ples em i kisim olgeta samting em i wok long dispela pik, kukim olgeta dan pinis em i kisim tel bilongen bilong kot $i$ gowe (? $)^{2}$ long wara. Taim em i go stap long wara em i tanim olsem bikpela man. I gat longpela gras usket bilongen na tit bilongen tu i longpela. Taim tupela mama bilongen $i$ wet longen $i$ no ken na tupela $i$ tok olsem, "Ating nogut sampela man i kam kilim pikinini bilong mitupela."

Orait em i salim narapela i go. I go daun, i go lukim dispela bikpela masalai em i sindaun long wara. Orait em i kam tokim brata bilongen. Tupela i ranewe goap long wanpela bi::kpela--ei--wanpela bi: :kpela kalapulin nau wokim haus antap. Tupela i stap antap. Tupela i stap antap longen. Orait masalai i kam i tanim ken olsem pikinini i kam long haus i tok, "Mama opim dua." Tupela i no stap. Em i brukim haus painim tupela i go long as bilong dispela kalapulin. Em i goap i go antap tupela $i$ tekwe hap skin bilong kalapulin antap tru long namel bilongen. Em $i$ goap $i$ go $i$ go $i$ gowe long dispela. I pundaun i kam daunbilo em i dai. Tupela i katim em dilim long olgeta kain pisin na olgeta kain samting long bus tupela dilim dispela ol mit bilong masalai longen. Na givim lewa ${ }^{3}$ bilongen long wanpela bikpela pisin i save plai antap. Orait ol i no kaikai yet dispela pisin i kaikai lewa bilongen pinis. Taim masalai tok long bungim bek olgeta skin bilongen olgeta skin bilongen $i$ kam bek tasol lewa bilongen i no kam bek. Na em i dai olgeta. Em tasol. 4

[Playing time: 5 minutes]

\footnotetext{
${ }^{l_{f i k u s}}=a$ kind of banyan tree, a species of Ficus, a rubber tree (commonly called fig tree). E.g. blut bilong fikus rubber sap; katim skin bilong fikus to tap a rubber tree.

${ }^{2}$ kot i gowe (?) It is not clear what was said here.

$3_{\text {lewa }}=$ innards. It may also (in other contexts) stand for desire (seat of affections) e.g. dispela i lewa bilong ol this is something they really crave for or even darling or sweetheart, e.g., lewaboi, lewameri you're my sweetheart. [footnotes continued overleaf]
} 
4 Some constructions are worthy of note:

1. Wanpela i go long narapela wara...na wanpela i go long narapela wara. Each went to a different river.

2. taim tupela i go narapela $i$ no save long narapela. When the two of them went each didn't know what the other was doing.

3. Tupela i kaunim olgeta kindam na pis na maleo. Bilong Asa $i$ no planti na bilong Elu i planti moa. The two of them counted all the crayfish, and fish and eels. Asa didn't have many while Elu did.

4. masalai i tanim long liklik pikinini, the (water) spirit turned masalai i tanim olsem bikpela man into a small child/big man

\section{TEXT 5}

Famili Bilong Mi by Mathias Kama, from Rabaul, New Britain District. This text was recorded by Mathias at the University of Papua-New Guinea, 1971. Here is the text:

Nem bilong mi Matias Kama. Na mi wanpela sumatin long Yunivesiti bilong Papua Hiu Gini. Ah--hap ples trumi kam longen em hap ples mama i bin karimmi longen, em bilong Rabaul. Em--na mi wanpela long ol dispela ah--lain ah--man bilong Papua Niu Gini, ol i kolim long Tolai. Mi wanpela Tolai ia. Ah--olsem mi tok pinis bipo mi wanpela yet bilong Tolai em na sabdistrik bilong mi long Is Niu Britin. Ah-na bai mi laik tokim yupela liklik long ah--famili bilong mi--olsem long mama bilong mi long brata na susa bilong mi. Ah--mi nambawan pikinini tru long wanpela bikpela lain ia bilong papamama bilong mi. Mi nambawan na i gat etpela moapikinini bihain long mi. Olsem mi tok pinis bipo mi nambawan pikinini na i gat ating--fo--mi gat fopela brata olgeta na--nogat sori, mi giaman--mi gat tripela brata na tripela--fopela susa. Ah--stret nambatu long mi em wanpela brata em man--pikinini man--na em i wok pinis. Mi sumatin yet na em i go wokpinis ia na mi save kros long dispela samting ia bikos mi skul yet na em i go pinis wok ia. Orait em i go skul long wanpela skul ia, wanpela aprentis skul, ah--long Bulolo long hap bilong bikples yet Niu Gini. Ah--kain wok em $i$ wok longen em $i$ wok long bikpela kampani $i a$, am--ol i save wokim ah--plaiwut longen ah--kampani, ol i kolim long ah--Niu Gini Timbis ah--Komonwelt Limitid. Ah--em i wok tupela yia pinis. Orait namba tri olsem em i meri ia, pikinini meri, em susa bilong mi. Ah--em--em i go wok tisa pinis ia. Em i aut pinis long skul. Em i wok tisa nau. Em i bin wok pinis olsem tisa long tupela yia. Orait namba fo nau em wanpela sista gen ah--na em i aut pinis long skul tu (ta) sol em i bihainim pinis wanpela kain lain ia, lain misinari, bilong katolik misin. Em ol i kolim long sista ia. Orait bihain long en em i gat wanpela meri ah--tasol ah--papa i kros liklik 
ia. Em i no laik--em i lukim planti tumas long mipela i gowe long ples na em i laik pasim em. Ah--olsem dispela meri, ah--susabilong mi i stap tasol long ples i go long skul na i gobek long ples olsem ah--wanpela tingting bilong papa i olsem. Mipela olgeta i iusim pinis tupela mama na olsem em i laikim bai wanpela long mipela i stap lukautim ol. 01 sem i olpela pinis. 01 i no inap moa long wok strong. Orait bihain tru i gat tupela brata. Oisem mi bihainim wanpela am-tupela liklik yet. Wanpela i stap long standet tu na wanpela i stap long klas wan. Ah--na bihain tru namb--laspela tru em wanpela susa. Em i no go long skul yet. Em i stap long ples tasol. Ating em tasol mi laik tokim yupela longen long olsem long famli bilong mi. Ah-haumas brata na susa bilong mi na wanem hap mipela i kam longen olsem long Niu Gini stret. Olsem mipela laik kolim mipela olgeta i bilong Niu Gini (ta)sol em i narakain liklik ia long Niu Gini ia. ${ }^{1}$ Sapos yu kam hia yu mas tok stret long wanem hap tru bilong Niu Gini yu kam longen. Nau olsem mi tokim yupela ah--mi--mi kam long Niu Britin long sabdistrik Kokopo long bikples, bik sabdistrik ol i kolim long Is Niu Britin Distrik. Orait, em tasol.

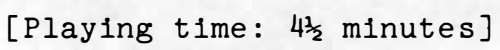

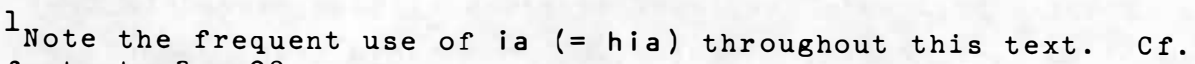
footnote 3 p. 90 . 


\section{TEXT 6}

Bikpela Nid, by Geresem IGUA (m) from New Hanover Is., New Ireland District. This text was recorded by Mr. Clive Beaumont, Research Scholar, A.N.U., in November, 1972. Here is the text:

Nem bilong mi Geresem lgua na mi kam long N--hap bilong Niu Hanova, long hap bilong Niu Ailand distrik. Nau mi laik toktok long bikpela nid i stap insait long wok bilong tanim toktok i go long ol tokples bilong yumi. I tru dispela kain tingting i no bin kamap bipo yet tasol nau tasol i bin kamap long sampela tingting bilong ol man ol i laik helpim yumi ol man long Papua Niu Gini bai yumi i mas kisim save long tokples bilong yumi yet. I no gat planti man ol i stap long dispela wok long tanim tok. I gat sampela man tasol bilong ol, olsem ol brata bilong yumi long narapela hap long ol kantri, ol i kam na ol i wok insait hap bilong yumi nau ol i wok long tanim sampela tok i go long tokples bilong yumi yet. Na i no gat man tru bilong hap bilong yumi long Papua na Niu Gini bai i stap insait long dispela wok. I tru i gat sampela man ol i skulim ol long dispela kain wok. I gat bikpela nid long yumi ol man yet bilong Papua na Niu Gini bai yu mas holim dispela wok bai i gat--bai yumi yet em i tanim ol tokples bilong yumi i go long ol--tokples bilong ol man, ol meri long ol ples bilong yumi wan wan. I gat planti kain tokples i stap insait long papua Niu Gini tasol yumi i no tanim olgeta. Yumi $i$ wok long tanim tasol sampela. Tasol i gat bikpela nid bai sampela man ol i ken kam insait long dispela ol $i$ ken wok long tanim tokples bilong yumi bai or pipel ol $i$ ken save na ol i ken painimmining tru long ol tok bilong ol. I tru tok Pisin em i--i stap insait long Papua Niu Gini tasol long sampela hap i no--ol i no save long tok Pisin. Olsem nau em i gat bikpela nid long yumi bai yumi mas givim lait longen. Yumi mas kam na wokim dispela wok bilong tanim tokples bilong yumi yet long ol buk long buk --buk--long Baibel o long wanem kain buk bai ol pipel bilong yumi ol i ken save long as tru bilong ol dispela buk.

[Playing time: $2 \frac{1}{2}$ minutes] 


\section{TEXT 7}

Toromuimui, by Moonaa from Paariro village, Buin, South Bougainville. This text comes from Laycock (1970:61-2). Here is the story:

Orait mi laik mekim stori bilong Toromuimui. Wanpela taim ol man i laik go katim bus. 01 i laik mekim nupela gaden long ples bilong Toromuimui. Orait na ol i kirap i go nau, ol i katimbus na katimol diwai, ol i lusim na i go bek nau. I go bek long ples na tulait ol i laik go kukim nau. Orait na ol i laik go kukim, olgeta diwai na bus i grobek i stap no ol i go lukim. 01 i go lukim na ol i tok, "He, wanem samting ol i kirapim bek--ol diwai na ol bus." Orait na ol i no save na ol i lusim i go long ples nau. I go long ples na ol i lusim wanpela man. Em i tokim ol, "Baimbai mi stap hia; yupela olsem bai yu go long ples; mi wet, wanem samting olsem ol i save kamkirapim bek tispela samting hia, diwai na bus." Orait na em i hait i stap, na Toromuimui i kamap nau. Kamap nau ol i lukim em. Em i kam na goap long as bilong diwai. Na i sanap na i singaut, singaut olsem, "Toromuimui, Toromuimui, Toromuimui." Orait na em i tok olsem na ol diwai i gro bek. Orait na dispela man i tok, "O a, em dispela samting ol i save kam kirapim bek ol diwai." Orait na i lusim na i go bek. I go bek long ples na tokim ol sampela man, "He samting ol i save kirapim bek ol diwai mi painim nau." Orait, tulait nau, na olgeta i go. I go wok gen, katim bus na katim ol diwai. Orait na ol i tok, "Tude bai mipela olgeta i stap hia." Orait na ol i stap na Toromuimui i kamap. I kamap na $i$ kam goap long as bilong diwai, na em $i$ sanap na em $i$ singaut, em $i--$, "Toromuimui, Toromuimui, Toromuimui." Orait na ol man i lukimem nau ol i ran i go holimem, holim em long longpela gras bilongen. Orait na pasimem long as bilong diwai na ol i kilimem. Kilimem na olgeta i go bek nau long ples, orait na bihain ol i wok long gaden bilong ol. Em tasol.

[Playing time: $2 \frac{1}{3}$ minutes] 


\section{TEXT 8}

Tupela Brata. A story by a Gadsup speaker from the Eastern Highlands. This text comes from Wurm (1970:168-71). Here is the story:

As bilong dispela stori, bipo, tupela brata i stap, na, ol i mekim, tupela brata kirap nau, em i kirap, giamanim em na dispela brata bilongen kiraf, giamanim em, tupela bipo mekim olsem bagarapim skin bilong tupela. Nau dispela stori mi laik i kamautim. Na nambawan taim nambawan brata i go putim trap long bus. Kisim dok na i go putim trap--trap long bus long muruk. Na muruk i go i go taimapim long dispela rot, na brata bilongen i go kisim, i kam putim long arare long ples. Na tokim nambatu brata bilongen tok, "Brata, yu go kisim muruk na kukim kaikai wantaim ol pikinini meri." Na nambatu brata bilongen kirap i go lukim nau. I go lukim na i go kisim i kam kukim kaikai wantaim ol pikinini meri. Na nambatu brata bilongen kirap askim nambawan brata, "Yu kilim olsem wanem?" Na nambawan brata bilongen ki rap giamanim nambatu i tok, "Mi go wokabaut long bus, painim nau, muruk i wokabaut na mi ranim nau, mi rausim bilum bilong mi, long narapela hap. Na mi ran i go yet, mi rausim pulpul bilong mi long narapela hap. Mi ran yet mi painim, mi lusim banarabilong mi long narapela hap. Mi ran yet $i$ go $i$ go $i$ go $i$ go, mi bagarapim lek bilong mi, skrubilong mi, rausim skin, blut i ran nating, mi ran ran ran longen, mi go holim pas longen. Na mi kilim, mi kisim i kam nau yu lukim, yu kaikai. Na yu laikim mekim olsem yu ken.

Na nambatu brata bilongen em harim pinis na i tok, "I orait, yu nambawan brata bilong mi yu mekim olsem, na ni, mi ken traim." Na nambatu brata bilongen, slip nau, moningtaim kirap i go long bus, i go nau i go painim wanpela liklik pisin i olsem poroman bilong kakaruk, na i painim pinis nau i tait longen i ran nau. I ran nau lusim bilum long narapela hap. Em i wok...long...ran yet, i lusim banara bilongen, bilum, ol samting bilongen, lusim nabaut long bus. $\mathrm{Na}$ i ran yet, i go painim nau, i go holim. Na dispela brata bilongen i bagarapim skru na lek bilongen, i pas long diwai o stik o samting, na blut i ran nating long lek bilongen. Na i go holim dispela pisin pinis, kisim i kam daun. I kam haitim long.....klostu long ples, na i kam tokim brata bilongen, nambawan. Na i tok, "Brata, mi kilim muruk i kam pinis, na yu go kisim, kukim kaikai wantaim ol pikinini meri." Na em i go lukim na i tok, "O brata yu no kilim muruk, yu kilim liklik pisin, pisin nating." Na em i go kisim na i kam kukim kaikai. Na brata bilongen harim na em i kisimbikpela sem. Orait, em i go kisim na i go wokim, i go katim wanpela liklik wail karoka long bus. Na i wokim liklik garamut long dispela, na kisim dok, mekim 
( Text 8 - continued)

samting bilong ol bipo. Na wokim dispela samting na kisim i go long wara, long raunpela wara, liklik wara. Na i go putim nau, i kam bek, slip, na kirap i go lukim nau moningtaim, na maleo i go daun long dispela garamut. \& stap nau, i go lukim na i kilim. Kilim, kisim i kam putim long klostu long ples, na i kam tokim bratabilongen, na i tok, "Brata, yu go kisim maleo na kukim kaikai wantaim ol pikinini meri, wantaim." Na em i go kisim nau, kukim kaikai wantaim, na kirap askim nambatu brata bilongen. "Yu kilim olsem wanem?" $\mathrm{Na}$ em i kirap tok, "O brata, mi kukim draipela kaukau, planti moa. Mi kukim, mi kisim draipela bilum, mi pulimapim, mi karim i go long het bilong plang. Mi go sindaun long het bilong plang, mi wok long kaikai kaikai dispela kaukau, mi pinisim tru, mi kirap nau pundaun. Mi kalap i kam daun long raunpela wara, mi siubim han i go, mi holim maleo. Yu ken mekim olsem." Na nambawan brata bilongen em harim i tok, "o liklik bratabilong mi yu traim olsem a?" "Mi ken." Na em i kisim nau, stat long kukim kaukau nau, kukim pinis, kisim draipela bilum pulimapim long bilum bilongen, karim i go antap long het bilong plang. Na em i go i stap, kaikai pinis, kirap nau, kalap i kam daun long raunela wara, em i kam bagarapim han-skru bilongen tasol i pilim nating na, giaman bilongen i siubim han i go long wara, i holim liklik pis. Holim pis na i go haitim long klostu long ples.

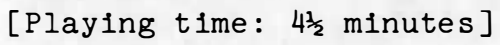




\section{TEXT 9}

Toktok long wanpela meri i bin ranawe, by a Melpa speaker from near Mt. Hagen in the Western Highlands District. This text was recorded by Dr. W. Clarke, Department of Human Geography, A.N.U. in 1971. Here is the text:

Em nau narapela tok mi laik wokim longen long nambawan brata bilong mi em i bin marit wantaim wanpela meri klostu long Maunt Hagen. Em-nem bilong dispela meri em meri kut. Em i bin ranawe long man bilongen na dispela nambawan brata bilong mi em maritim dispela meri. Tasol wanpela taim, em i bin i go daun long Mul long skul, na em $i$ laik wok liklik long helpim ol skul, na em i godaun nau. Bihain wanpela draiva bilong trakta i karim em i kam antap long Kerua, wanpela ples ol i kolim Kerua. Na ol i wokim wanpela Roman Katolik Sios long dispela hap. Na ol i karim wan--sampela plang i go antap. Na bihain ol i jekim dispela plang i go pinis, nau draiva i tok, long brata bilong mi, em tok, "Yu rausim--yu mekim--wanem?--yu go long dispela--l bringim dispela trak i kam bek nau kilimensin bilongen." Nau brata bilong mi i tok, "Eh, bai mi kilim olsem wanem? Mi no save. Mi no save draiv o mi no save long dispela kain samting." Na bihain em kirap gen, na em tok, "Nogat, i no hatpela samting. Yu kilim dispela ensin bilongen." Nau em tok, "Bai mi kilimolsem wanem? Mi tanim gia, nogat. Em i no indai tu." Nau bihain em kirap gen na em tok, "Nogat, yu pulim wanpela liklik waia i stap klostu long rait han hia." Na em laik pulim em, nogat. Hap han bilongen em lusim gia longen, nogat. Abrus bilongen, hap han bilongen tasol i go na tanim gia i go antap long fes gia nau trak i muv. Na dispela man i sindaun klostu long bikpela draipela wil sanap longen nau trak i mov pinis em kilim dispela. I go antap long trakta na em kilim skru na em go katim solda bilongen na insait bilong dispela bun i bin bruk. Na dispela em --ol salim em $i$ kam long haus sik long taun bilong Maunt Hagen stret. Na em i stap long haus sik. Na bihain ol a--em harim man--meri bilongen em $i$ go marit wanpela man klostu long Kuk. Nau bi--em i stap long haus sik $i$ go $i$ go $i$ go, han bilongen $i$ orait bihain ol dokta $i$ tok, "Orait yu mas goan bek long ples bilong yu." Nau bihain em $i$ kam bek long ples bilong mipela em $i$ stap, em i harim dispela meri i go bin marit wantaim narapela man. Nau em kam tokim mi, na mi tu mi go tokim ol narapela lain. 01 narapela man tu ol sindaun long ples yet, mipela i goandaun long dispela ples long nait. Mipela $i$ go $i$ go i go go long kamap long Kuk stret. Mipela lukim dispela meri kaikai sampela buai wantaim dispela man i bin marit longen, tupela i sindaun

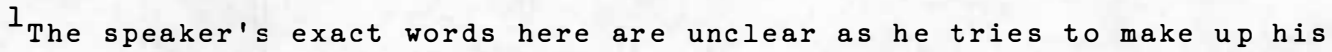
mind what to say. 
long sit bilong paia klostu. Mi kam insait tasol. Mi tok, "Eh meri, yu mekim wanem? Yu bin marit wantaim brata bilong mi na nau yu kam marit gen long narapela man. Em wanem kain pasin yu laik wokim?" Mi kirap nau, mi pulim han bilongen. Mipela laik--mi pulim em i kambek. Mi paitimem. Nau dispela man i bin marit longen em tu i bin pret nogut tru. Nau em i go insait long wanpela rum na hait i stap. Tasol mipela no paitim dispela man, mipela paitim meri stret. Mipela karim i kam bek long ples gen. Nau dispela meri i stap long ples gen nau, mipela kam kot. Brata bilong mi paitimem nogut tru. Em i paitimem. Blut tu ran na bis na samting olgeta em putim long lek, i bin bruk. Laplap tu. Olgeta samting i bin paul olgeta. Na dispela meri mipela bin pulimem i kam i kam i kam i kam long haus bilong mipela stret. Em sindaun long haus nau. Bihain gen em ranawe gen. Nau mipela go kot gen nau putim em long lokap. Nau tumara long Fraide bai mipela i gat bikpela kot long dispela meri. So tasol--plisman nau ol--wanem?-welfe ofisa na sabdistrik kot mipela laik goap wantaim long dispela sabdistrik kot pastaim. So, olsem, mi no harim i no inap, orait mipela kam daun long welfe gen. Nau welfe mas stretim nau putim dispela meri long lukaut o salim long kalabus o mipela no save. Tasol em samting bilong gavman. Tasol draipela kot i stap long dispela meri bilong tumara, long Fraide. Em tasol toktok bilong dispela meri wantaim man tupela bin--man $i$ bin--wanem?--pundaun long trak na meri $i$ bin ranawe long man bilongen olsem dispela stori mi tokim yupela long Pisin. Em tasol tok bilong mi.

[Playing time: 4 minutes] 


\section{TEXT 10}

Pasin Bilong Kilim Muruk long Trap, by Yapua Kirapeasi, from Usa village, Kagua Sub-District, in the Southern Highlands. This text was recorded by Dr. K. J. Franklin, Summer Institute of Linguistics, in October 1972. Here is the text:

Long ples wanpela man i stap. Nem bilong em, Eka. Dispela man em i man bilong kilim muruk. Long wanpela taim em i wokabaut long bus bilong em, maunten Wakalu. Na em i wokabaut i go na wanpela samting i mekim nois. Em i lukluk nau em i iukim bikpela muruk. "o, i no longtaim bai mi wokim trap," em i ting olsem na dispela man em i lukluk long--taimmuruk i ranewe na em i go klostu na i lukim. Tasol em i--i save kisim pikinini bilong diwai long wanpela diwai prut bilong em i retpela na $i$ mau $i$ stap, i pundaun na dispela muruk $i$ wok long kaikaiim dispela prut. Nau Eka i kam long bus nau redim samting bilong wokim trap. Nau em i kam kisim strongpela rop ol i kolim kanda. Na em i pulim longpela diwai strongpela tru. Na em i kisim i go long rot bilong muruk na em i laik wokim trap. Na em i wokim wanpela diwai i olsem rot bilong muruk na wokim trap put--pasim rop antap long het bilong dispela diwai na em $i$ wokim. Wokim pinis na muruk i noken lukim em i pasim sampela samting long taim em i wokim rot bilong--rot longen. Muruk i no ken lukim. Nogut em i pret na $i$ wokim narapela rot. Em i ting olsem na i wokim gutpela tru na em i go long ples. I go long ples na i go stap tupela de o tripela de pinis, em i go lukim. Em i go lukim na muruk em i painim kaikai bilong em $i$ kam na em $i$ kam hangamap i stap. Em i kisim nek--long nek bilong em na muruk em i skir--lek bilongem i skrapimgraun na i slip i stap. Dispela man Eka i go kamap em i save brukim nek bilong em na karim i kam long ples. Em tasol. 


\section{TEXT 11}

Karkar Ailan i Kamap 01 sem Wanem, by Benno Paniu, Karkar Island, Madang District. This story was recorded by Dr. J. Z'Graggen, Anthropos Institute, Alexishafen, Madang District, in 1972. Here is the text:

Nem bilong mi Benno Paniu. Mi kam long liklik ples long Karkar ailan long Mangar. Nau mi laik toktok wanpela stori Karkar ailan i kamap olsem wanem.

Longpela taim i go pinis wanpela bikpela man ol i kolim jaint ${ }^{1}$ em i bin raun long hap bilong Bogia na $i$ wok long wokim ol maunten. Na dispela jaint em i wokim maunten long hap bilong Bogia i stap. Na dispela jaint em i bikpela tru em i winim olsem--i longpela bilong em i olsem ol longpela kokonas, na strongpela bilong em i olsem wan tausen man. Na taim em wokim wanem?--maunten $i$ stap na em i olsem maun--taim em $i$ wokim maunten em i no pilim olsem em i tait long wanem em $i$ amamas tasol na $i$ wok long wokim ol maunten. Na wanpela taim em i kamap (?)--em i laik olsem res² liklik na i kam antap long Manam. Na $i$ kam antap long Manam nau na long $\underline{s i}^{3}$ em--em i laik kam antap long Manam nau na i res. Nau na taimem i res i stap nau na wanpela bikpela retpela ent--ent--korakum o anis em i wanem?--kaikai long nek bilong em stret. Na tarangu i jaint ia i kalap nogut tru na i krai nau i singaut, na em i kalap i go daun long si. Em i kalap $i$ go daun long si pinis nau na em i wokabaut $i$ go long si yet. Em $i$ stap long si i go $i$ go i go i go raun long si i go i go nau na i go kamap long dispela hap. Nau na em i mekim maunten hia [in background Long wanem hap?]--long klostu long Karkar, long ples Karkar ailan nau i stap hia--na em i kamapim bikpela maunten hia nau na ples hia maunten hia nau ol i kolim Karkar ailan. Na bipo yet taim jaint i stap em i save salim smok na wanem?--klaut i go antap long maunten long wanem taim anis hia i kaikaiimem em i olsem em i kros na em $i$ subim i go daun long si nau na taim em i stap liklik long maunten em i kros bai em i salim wanem?--smok hia i go antap long volkeno. 4

\footnotetext{
$I_{\text {jaint }}=$ giant

2 res = rest. An English loan for what should have been malolo or kisim win. See also si and bloap below.

${ }^{3}$ Note here the speaker's use of si for sea instead of solwara which is the correct form.

${ }^{4}$ volkeno $=$ maunten $i$ save pairap $=$ volcano
} 
Olsem nau na taim em i olsem kros liklik long ol ent hiabai em i salim smok nau na ol pipel i lukim dispela smok i kamap na ol ting bai Karkar i bloap na ol i save sut nabaut long bikples. Em i stap $i$ stap i go i go na em i senisim tingting na em i--long bipo ol pipel i save tok i gat wanpela rot ananit iong si tasol i kam kamap long Manam. Nating ${ }^{2}$ em i stap $i$ go nau na ${ }^{3}$ em $i$ les nau na em $i$ wokabaut ananit iong si yet i kam kamap iong Manam. Na long dispela taim i no gat smok moa i kamap long Karkar ailan na $i$ no gat paia na taim em $i$ kam bek long Manam em i statim dispela smok na paia i kamap. Em tasol.

\section{$\left[\right.$ Musik $\left.k^{4}\right]$}

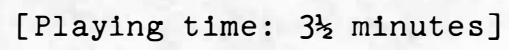

\footnotetext{
$I_{\text {bloap }}=$ blow up. This should have been pairap.

$2_{\text {nating }}=$ ating

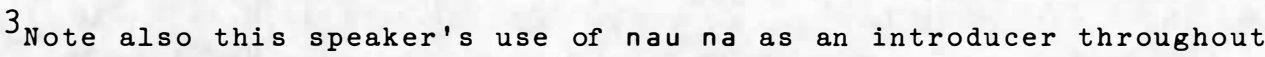
this text. Cf. Text 2, also from the Madang area, where the same was observed.

4 Munge. A feast dance with massed dancers carrying skin drums. The dance has just begun and the singing is a bit ragged. The elders can be heard as they move into the circle to chide the dancers and give orders to mark a change of steps and drum rythms. Sheridan (1958: track l, item a).
} 


\subsection{OTHER PACIFIC VARIETIES}

This section consists of illustrative texts from the Solomon Islands and the New Hebrides. I These varieties have developed along different lines from New Guinea Pidgin. They are more closely related to one another than either is to New Guinea Pidgin. However, they have not been systematically studied in the way that New Guinea Pidgin has been though they are now receiving more attention. The New Hebridean variety is generally referred to as Bichelamar, or Bislama. A short bibliography covering both varieties follows:

Camden, W. G. (1971?) Dictionary: English to Bislama. Unpublished mimeo., Vila.

Guy, J. (forthcoming) "Le Bichelamar Des Nouvelles-Hebrides." To appear in Te Reo, New Zealand.

Hall, R. A. (1945) "Notes on British Solomon Islands Pidgin." Modern Language Notes, 60:315-18.

(1955) "Pidgin English in the British Solomon Islands." Australian Quarterly, 27 (4):68-74.

Reinecke, J. R. (1937) "Marginal Languages: a Sociological Survey of Creole Languages and Trade Languages." Unpublished Ph.D. Thesis, Yale.

Various publications by foreign missions and the following by Résidence de France, Vila: Apprenons le Bichelamar (unpublished mimeo.) and the monthly Bulletin d'Information. P. O'Rellly's Hébridais: Repetoire Bio-Bibliographique des Nouvelles Hebrides (Sociétédes Océanistes, 1957), should also be consulted for possible additional references.

\section{SOLOMON ISLANDS TEXT}

This text is spoken by Mr. Wilson Ifanaol from Malaita. It is about Wilson's family and was recorded at the University of Papua and New Guinea, in August 1971. Here is the text:

Nem bilong mi Wilson Ifanaoi. Ah--mi kam from Solomon Ailans. An mi kam from wanfala ples olgeta kolem Malaita. Hom veri fa from Sol-Honiara ia. Mi karem sevenfala pipol um--boi na--mi karem sevenfala pikinini nau long famli bilong mi. Ah--fofala boi an trifala meri. An--mi--mi mek drim (?) boi insait long famli ia-tufala brata festaim; tufala marit nau. Hom karem famli bilong olgeta olgeta. Nau wanfala woman mo həm marit. Tufala long skul yet əm wanfala həm--brata--həm go long sekendri skul dis yia. Long houm am-mada bilong mi an fada bilong mi stopim wanfala olgeta no go long skul mekem em stap wetem olgeta long houm. Mekem lukafta olgeta am--go long wota, tekem wota fo olgeta an helpom famli. Am--distaim am--

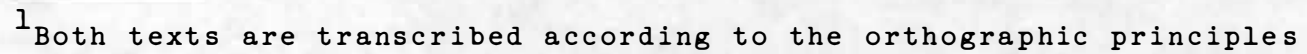
used in transcribing New Guinea Pidgin except for $\partial$ which is used to represent a central vowel sound which is like that in the be syllable of below when it is not pronounced clearly. The underlined forms represent differences from New Guinea Pidgin. Cf. the notes to the following New Hebridean Text. 
mada bilong mi an fada bilong mi tufala ol lelbit nau. Mifala no save am--baimbai haulong nabai (?) tufala stap fo. Am--from hia baimbai mi go bek long houm ating bai mi trai fo helpim olgeta lelbit. Am--bikos tufala brata bilong mi festaim tufala wok an karem famli nau hom hard lelbit for helpem olgeta olman so mi kam baimbai mi gou bek houm wok. Baimbai mi trai fo helpem ol--tufala olman bilong mi.

\section{[Playing time: 2 minutes]}

\section{NEW HEBRIDES TEXT}

This text is part of one collected by Dr. D. Tryon, Department of Linguistics, A.N.U., in 1970. Here is the text:

Wan storian bilong kaikai, we yu--evriwan yumi stap yusem long Niu Hebstri tude. Ah storian long ol kava ${ }^{l}$ ia em--em i telem olsem, se, "Wan de ol tri ol i miting long wol ${ }^{2} i a$. Ah--taim ol i stap storian ${ }^{3}$ ol i mekem wan bikfala miting long nakamal ${ }^{4}$ bilong olgeta. Ah--sip bilong ol tri ia, nem bilongen kokonas. A--taim ol i miting i stap ol i stap storian. Wan animal, nem bilongen, rat, em i wokabaut long ol tingting bilongen. Wantaim nau em $i$ folem $^{6}$ wan rus ${ }^{7}$ bilong nabaga. ${ }^{8}$ Taim i folem rot bilong nabaga ia $i$ folem $i$ go i go i go i go i go daun long botem ${ }^{9}$ we ol $i$ kolem narafala wol. Taim i go tru long narafala wol ia long daun i luk wan tri we em i grin i stap. Em i lukem we tri ia em $i$ go $i$ go $i$ go $i$ go $i$ gat wan plantesin bilongen we i stap long daun ia. Ah--taim rat i stap lukluk i harim smel ${ }^{10}$ bilongen we $i$ gud we $i$ gud. Em $i$ se, "O ating wan gudfala tri ia. Mi go traim sinelem gut moll mi mi go traim testem olsem wanem i gud

$l_{k a v a}$ is an intoxicating drink. Has great powers as the rest of the story enumerates.

2 wol $=$ world

$3_{\text {storian }}=$ story + yarn $=$ tell, talk

$4_{\text {nakamal }}$ men's meeting house, club house

${ }^{5}$ sip $=$ chief

$6_{\text {folem }}=$ follow

$7_{\text {rus }}=$ root

$8_{\text {nabaga }}=$ ficus tree

9 botem $=$ bottom

10 harem = to feel

${ }^{1 l_{\mathrm{mo}}}=$ and (also more in other places) 
bilong kaikai no. Tingting bilong rat i tingbaut olsem ia i go klosap nau. Taim i go klosap long tri ${ }^{l} i a, i$ go stap raun longen i traim long ol skin bilongen. Taim i kaikai ol skin bilongen long stampa ${ }^{2}$ i stap kaikai stampa nau. Taim i kaikai i mekem doti ${ }^{3}$ bilongen i go ah --i solem daun ${ }^{4}$ wara bilongen. Taim i stap wokem wokem wokem i no longtaim em i harem i dronk. 5 Taim i harem i dronk kava ia i tok long en. Em i se, "Eh, mi mi harem yu stap kaikai mi. Bai yu save mi. Mi mi kam ia long taim from mi stap antap mi luk olgeta tri we ol i olsem mi ol i doti. Mo ol i no gat samting. Mi lukluk olsem ia mi save ating mo gut mi go hait samples. Dastawei mi kam daun ia. Taim mi kam daun ia mi kam stap--mi kam stap yet tel ${ }^{6}$ tude. Ah--yu yu kam painem mi yu stap kaikai mi, mi stap harem. Bai mi telem long yu taim go antap yu go telem long ol tri yu go telem long olgeta se, "Wan tri i no olsem mi. Mi mi wan masta. Mi klin. Man--sapos wan man i kaikai mi, tut bilongen $i$ mo strong $i$ no save kamaot. Ah--lip bilong mi taim yu kukem yu swim long ${ }^{7}$ en yu neva gat sua. Yu neva gat wan sua long skin bilong yu. Yuklin nomo stap. [Playing time: 4 minutes] $\left[\right.$ Musik $\left.{ }^{8}\right]$

\section{SOME COMPARATIVE NOTES ON BICHELAMAR AND NEW GUINEA PIDGIN}

The following are some of the obvious differences between New Guinea Pidgin and its sister Bichelamar. Notice that where these two differ, especially in vocabulary, the New Hebridean form is generally closer to English than the New Guinea equivalent.

\section{(a) Phonology New Hebrides New Guinea}

Some differences in pronunciation of similar vocabulary items:

$\begin{array}{lll}\text { to eat } & \begin{array}{c}\text { kakai (sometimes } \\ \text { kaikai) }\end{array} & \text { kaikai } \\ \begin{array}{l}\text { suppose, if } \\ \begin{array}{l}\text { transitive verb } \\ \text { marker }\end{array}\end{array} & \text { sipos, supos } & \text { sapos } \\ & \text { v-em, V-im, V-um } & \text { v-im }\end{array}$

\footnotetext{
${ }^{1}$ Note use of klosap near to where in New Guinea Pidgin one would use klostu. 
$(B)$

Grammar New Hebrides New Guinea

(1) Pronouns: same except for emphatic (double) pronouns:

$\begin{array}{ll}m i \text { mi } & \text { mi yet } \\ \text { yu yu } & \text { yu yet }\end{array}$

(11) Possession: same in both--bilong

(iii) Adjectives -fala used for emphasis
Many have - pela and some come before and after nouns. Many classes.

(iv) Demonstrative ia here, this used more than in New Guinea where dispela is common:

$$
\text { ston ia dispela ston (hia) }
$$

(v) Numbers up to 10 same except New Guinea uses - pela forms:

$$
\text { wan tri wanpela diwai }
$$

(vi) Indefinite Article (same as for numbers above):

$$
\begin{array}{ll}
\text { wan man } & \text { wanpela man } \\
\text { wan samting } & \text { wanpela samting }
\end{array}
$$

(vi1) Continuous Tense:

$$
\begin{aligned}
& \text { i stap } V \text { always } V i \text { stap and less } \\
& \text { common } i \text { stap } V
\end{aligned}
$$

(viii) To want to do V:

$\begin{array}{lll}\text { (ix) Relative Clauses: } & \text { i wantem } V & \text { i laik } i ~ V \\ & \text { Introduced by we } & \text { No connective e.g., } \\ & \text { e.g., (wan ples we (wanpla ples Got i } \\ & \text { Got } i \text { stap longem) stap longen) }\end{array}$

(x) Reason Clauses (because)

$$
\begin{aligned}
& \text { from we + clause bilong wanem/bikos }+ \\
& \text { clause } \\
& \text { tel, (i) kasem }+ \text { inap long + clause } \\
& \text { clause }
\end{aligned}
$$$$
\text { (xi) Until }
$$

\section{(c) Vocabulary}

$\begin{array}{lll}\text { English } & \text { New Hebrides } & \text { New Guinea } \\ \text { woman } & \text { woman } & \text { meri } \\ \text { small, little } & \text { smol } & \text { liklik } \\ \text { nogood, bad } & \text { nogud, bad } & \text { nogut } \\ \text { alz, everyone } & \text { olgeta, evriwan } & \text { olgeta } \\ \text { yesterday } & \text { yestede } & \text { asde } \\ \text { Vtrans. } & \text { V-em, V-im, V-um } & \text { v-im } \\ \text { alcoholic drink } & \text { strong dring, grog dring gat kik/pait } \\ \text { to stop (tr.) } & \text { blokem, stopem } & \text { pasim, stapim } \\ \text { together with } & \text { wetem } & \text { wantaim, tupela } \\ \text { wood } & \text { wut } & \text { paiawut, diwai } \\ \text { sun rises } & \text { sun resap } & \text { san i kirap } \\ \text { duck } & \text { dak dak } & \text { pato } \\ \text { because } & \text { from we, bikos } & \text { bilong wanem, bikos } \\ \text { ashes } & \text { asis bilong paia sitbilong paia } \\ \text { how } & \text { olsem wanem,wiswe, olsem wanem } \\ \text { buizd } & \text { waswe } & \\ & \text { bildim, mekem, } & \text { wokim (not mekim) } \\ & \text { wokem }\end{array}$




English
wrong
diarrohea
enemy
enclosure
send
boy
weeds
throw
untiz
poor
club
sorcerer
why?
only
but
to say
who, which
happy
Future V
vilzage
sky
beach, sand
true home
to tell a story
meeting house
animal
meeting
folzow
root
bottom, base, origin
to feel drunk
dirt, rubbish
dirty
swalzow
tell to
teeth
to bathe in
never
and
then
born

New Hebrides

rong
sit wota
bad pren
barik, padok
sendem, salem
boi
rabis gras
sakem
tel, kasem
i gat nating,
puaman
nalnal
kleva (man)
bilong wanem, from
wanem
nomo
be, me, bat
(telem) se
we
glad, harem gut
baimbai/bai V
velej
skai
sanbis
prapa ples
storian
nakamal

animol

miting

folem

rus

botom, stampa

harim i dronk dot $\mathbf{i}$

dot $i$

solem daun

talem long

tut

swim long

neva, no samtaim mo

saye, ale

bon
New Guinea

kranki

pekpek wara

birua

banis

salim

manki

gras nogut

tromwe

inap long

rabisman

stik bilong pait man bilong mekim poisen

bilong wanem, watpo

tasol

tasol

i tok

- -

belgut, hepi

ba $i v$

ples, viles

heven

namb is

ples tru

stori long

haus tambaran, haus

kivung

abus

kivung, miting

bihain im

rop bilong diwai

as, baksait, ananit

bi long...

a i raun, i spak

pipia, das

$\operatorname{dot} \mathbf{i}$

daun im

tok im

t it

waswas long

i no save $V$

na

orait na

mama i karim(em) 
This index contains cross-references to all grammatical points introduced into the body of this textbook. Numbers following each head word or phrase in this index indicate the units or subsections of units in which the relevant material is discussed, or occurs first in the case of those items only casually introduced and not discussed. Footnoted material is indicated by the abbreviation (fn.) following the unit or section number given. References are given under both English and Pidig headings.

A

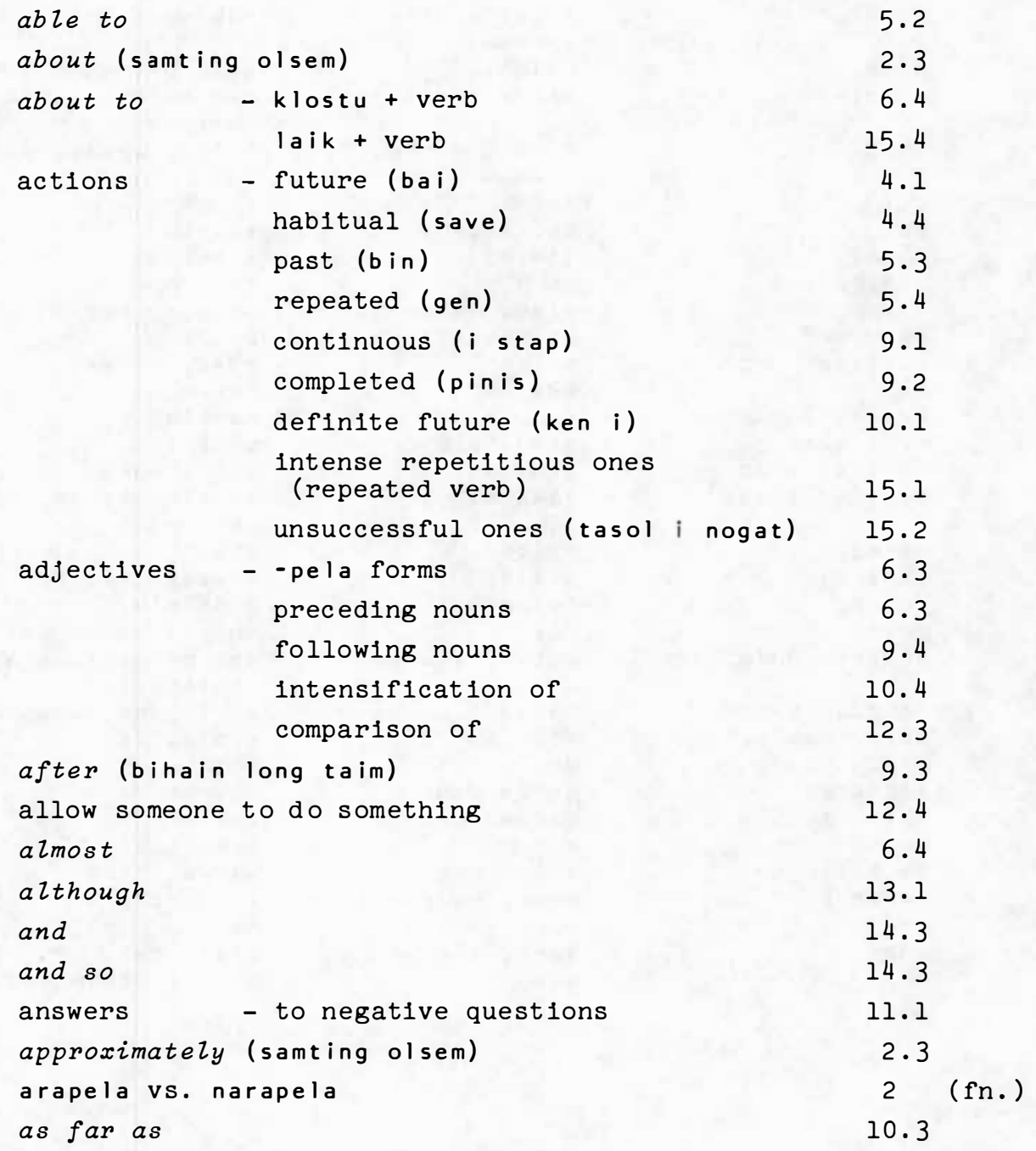




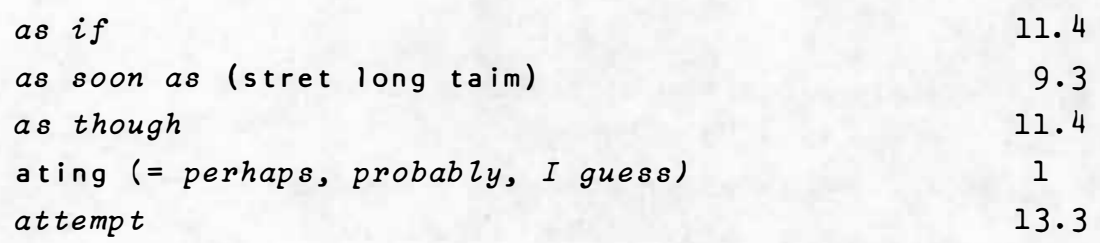

B

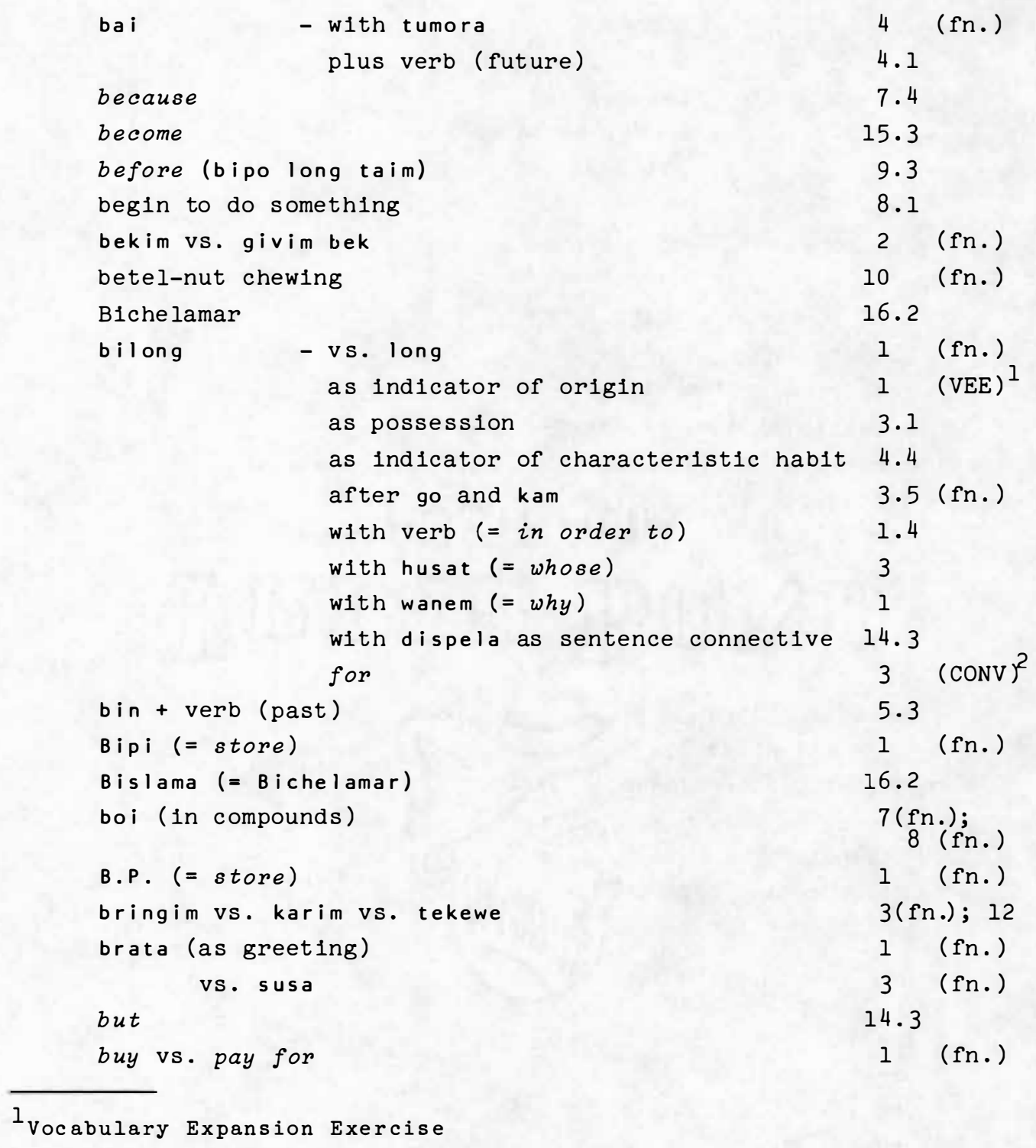




\section{C}

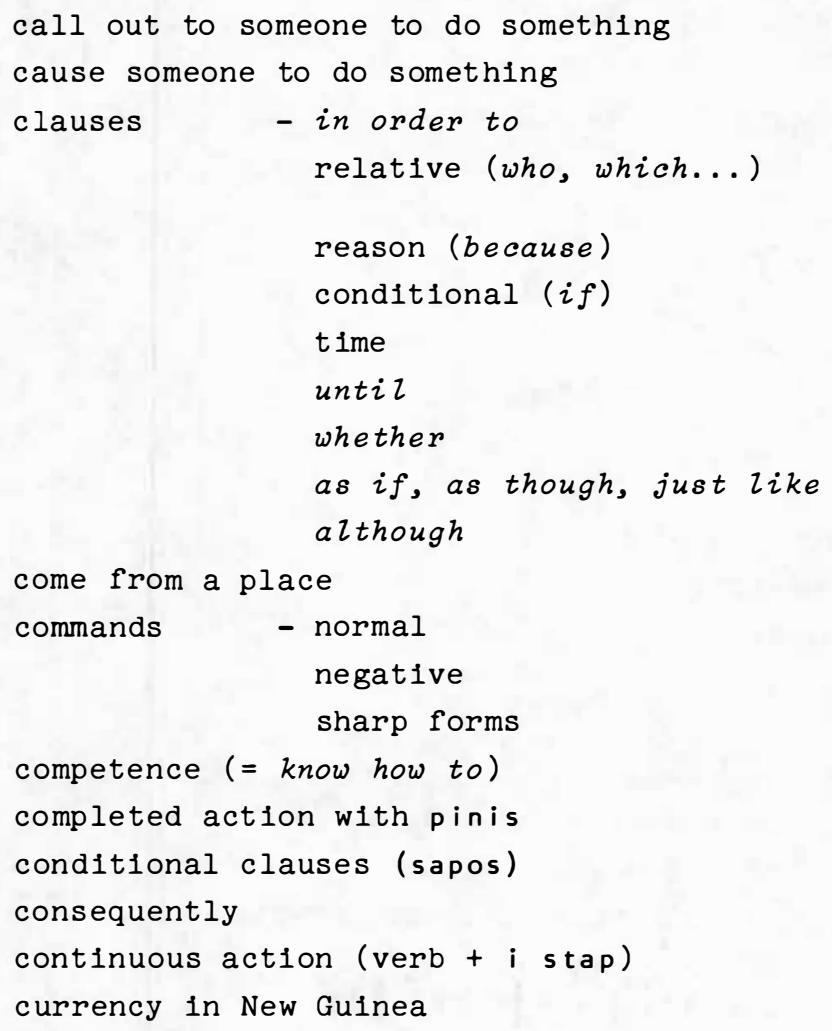

D

da $\mathbf{i}$

dates and days

days and dates

definit $\in$ future (ken $i+$ verb)

desire

dialects

distributive pronouns
6.2 (fn.)

4.2

4.2

10.1

2.2

16.1

13.2

E

\section{each}

em vs. em i

em vs. en

en VS. em

en $=01$

epithet:s
13.2

2.4

$3.1 ; 7$ (fn.)

3.1

8.5 (fn.)

3 (fn.) 
even if

13.1

every time (olgeta taim)

9.3

exclamations

3 (fn.)

exclusive pronouns

exhortations vs. statements

1.1

3 (fn.)

$\mathrm{F}$

farewells

female names

for that reason

future tense (bai + verb)

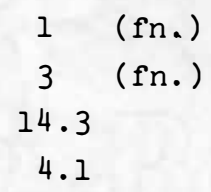

G

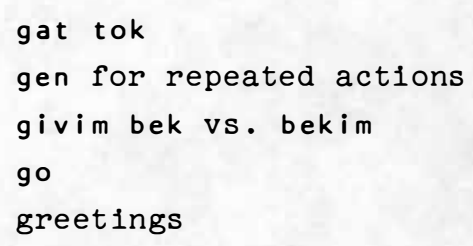

3.5 (fn.)

5.4

2 (fn.)

1 (fn.)

1 (fn.)

\section{H}

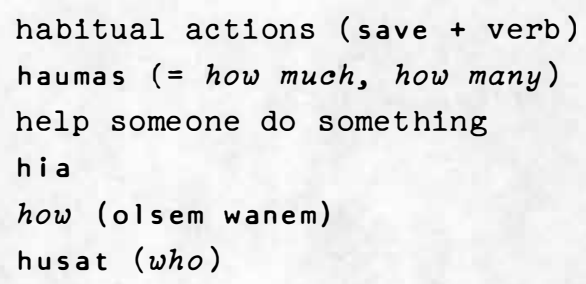
4.4 2
12.4 6 (fn.)
4
3

i da i

i gat (= there is/are)

$i$ go as direction marker

i kam as direction marker

imperatives - 3rd person forms

inap + verb (= ability)

inap long ( = until, up to, as far as)

inclusive pronouns

i no gat wanpela (= nobody, no one, nothing)
1.3; 4(fn.);

11

10.2

3 (fn.)

3 (fn.)

12 (fn.)

5.2

10.3

1.1

12.2 


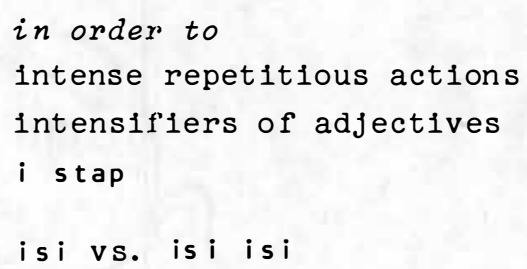

kam

kamap (:= become)

kamapim vs. kirapim

karim vis. bringim

katim and related expressions

ken + verb (= permission)

ken + verb vs. ken $i+$ verb

kirap + verb (= begin to V)

kirapim vs. kamapim

klosap + verb (= about to, nearly, almost)

klostu + verb ( = about to, nearly, almost)
1 (fn.)

15.3

7 (fn.)

3 (fn.)

4 (fn.)

7.1

7.1 (fn.); 10.1

8.1

7 (fn.)

6.4

6.4

laik (= to become)

15.3 (fn.)

laik + verb (= about to)

15.4

laik $i$ + verb (= want to)

2.2

laikim vs. laik i

10 (fn.)

lapun vs. olpela

6.3 (fn.)

larim and similar verbs

12.4

let someone do something

12.4

like that (olsem)

(to) like doing something

2.2 (fn.)

lohap = long hap

6 (fn.)

long vs. bilong

1 (fn.)

longen : long ol

8.5 (fn.) 
M

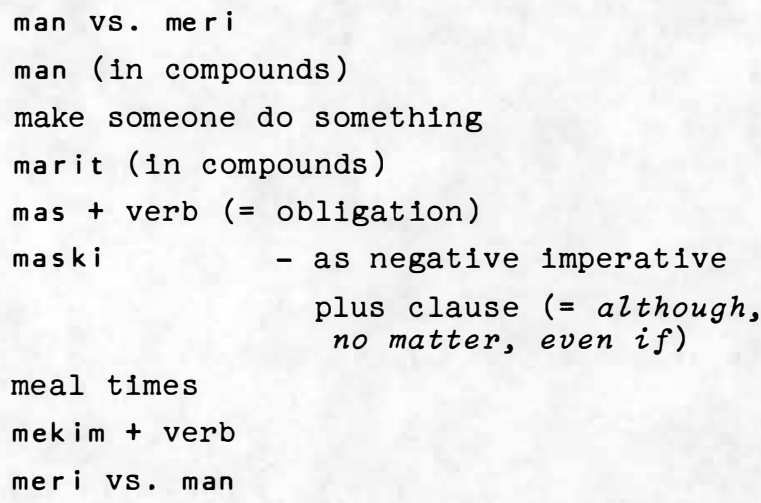

N

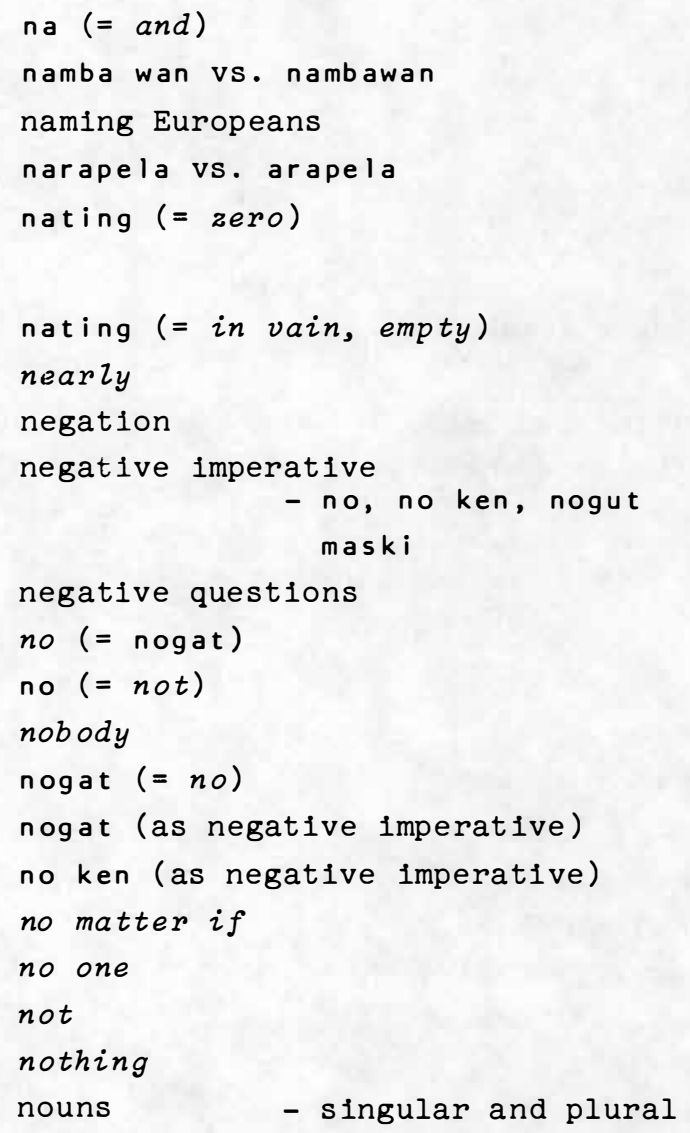


0

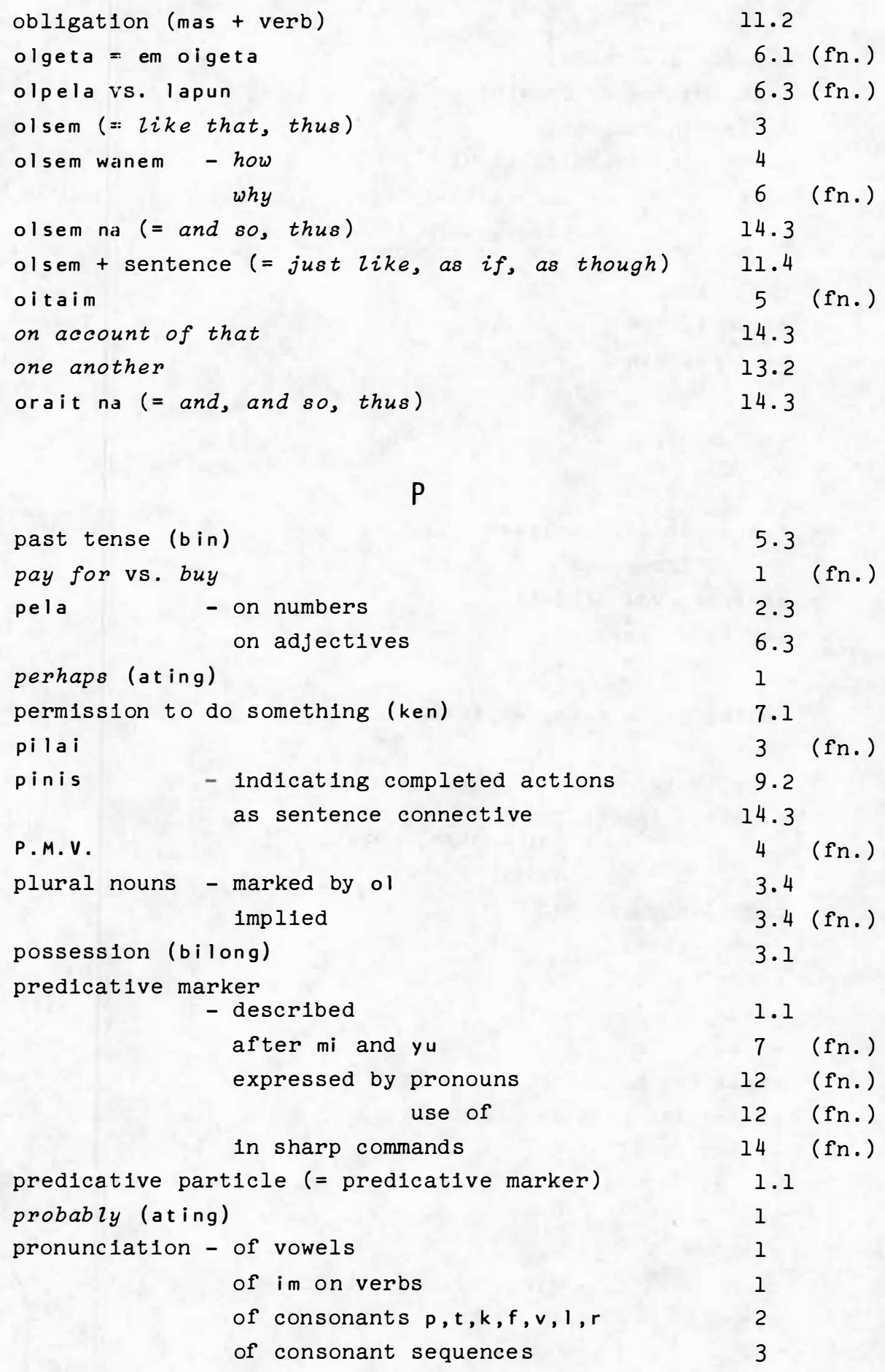




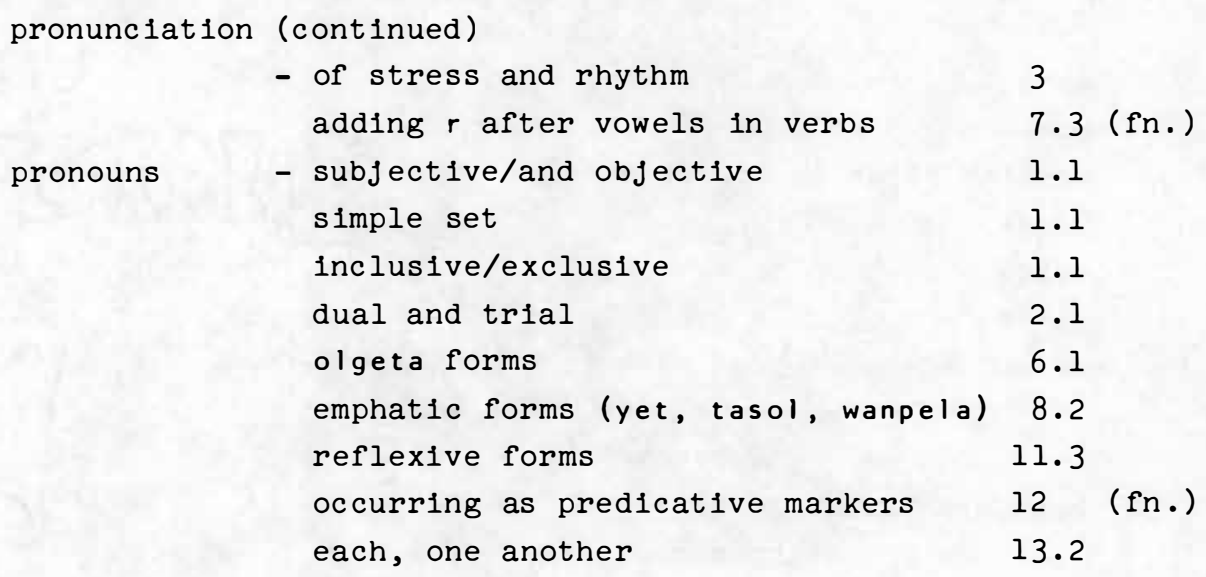

0

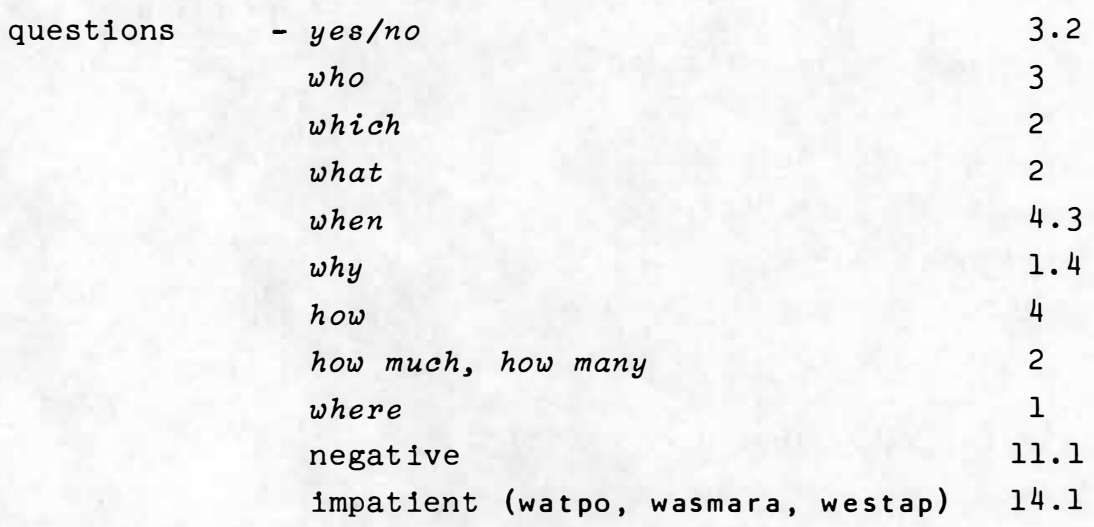

\section{R}

reason clauses (because)

reciprocal pronouns

reduction of sentences and sequence of time

relative clauses

- who, which, what

to whom, to which, whichever, whoever 7.5 where, what

repeated actions (verb + gen)

repetition of verb
8.5

7.4

13.2

14.2

6.2

5.4

15.1 
S

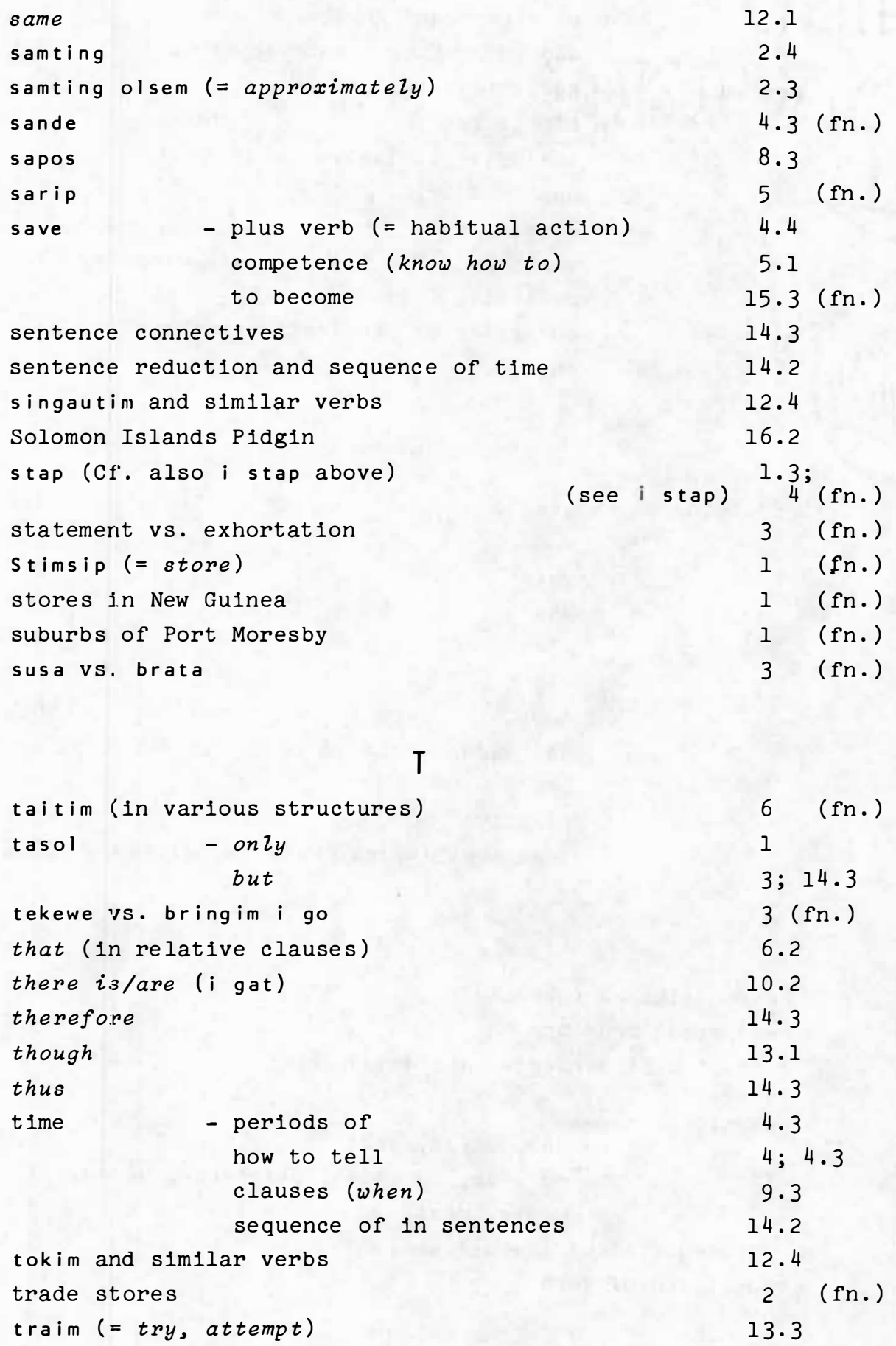

T

taitim (in various structures)

6 (fn.)

tasol

- only

1

but

$3 ; 14.3$

tekewe vs. bringim $\mathbf{i}$ go

3 (fn.)

that (in relative clauses)

6.2

there is/are ( $\mathrm{i}$ gat)

10.2

therefore

14.3

though

13.1

thus

14.3

time

- periods of

$4 \cdot 3$

how to tell

$4 ; 4.3$

clauses (when)

$9 \cdot 3$

sequence of in sentences

14.2

12.4

tokim and similar verbs

2 (fn.)

trade stores

traim ( = try, attempt)

$13 \cdot 3$ 
tru

try (traim)

tupela (= along with, and)

U

unsuccessful actions

until (inap long)

up to (inap long)
4.3 (fn.)

13.3

4 (fn.)
15.2

10.3

10.3

V

varlation in New Guinea P1dgin

Introduction; 16.1

vehicles (types of in New Guinea)

4 (fn.)

verbs

- form of

1.2

transitive marked by im

1.2

trans1t1ve unmarked by im

3.5

intransitive

1.2

stative vs. transitive

7.3

repetition of

15.1

verbless sentences

2.4

W

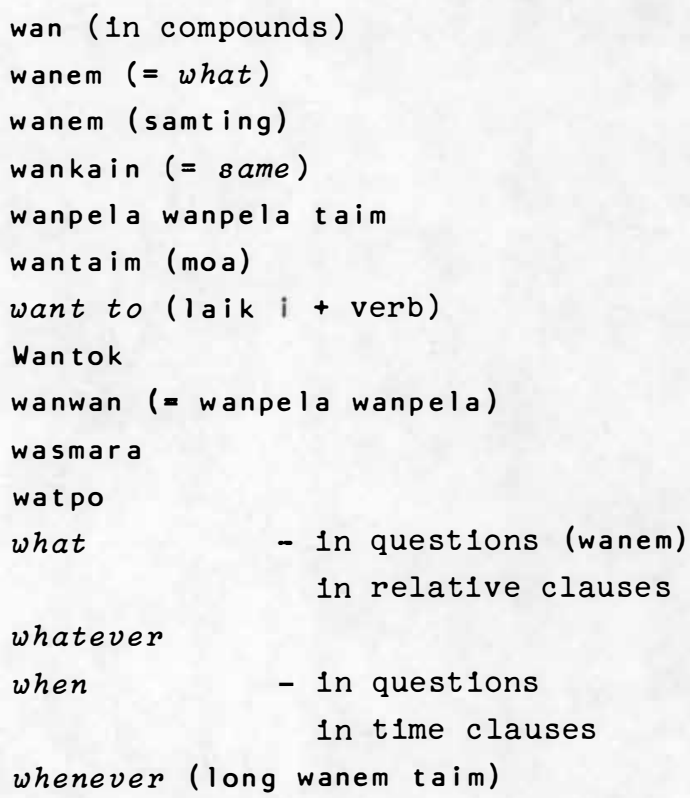

whatever

when

- In questions in time clauses

whenever (long wanem taim)

7.5

4.3

9.3 


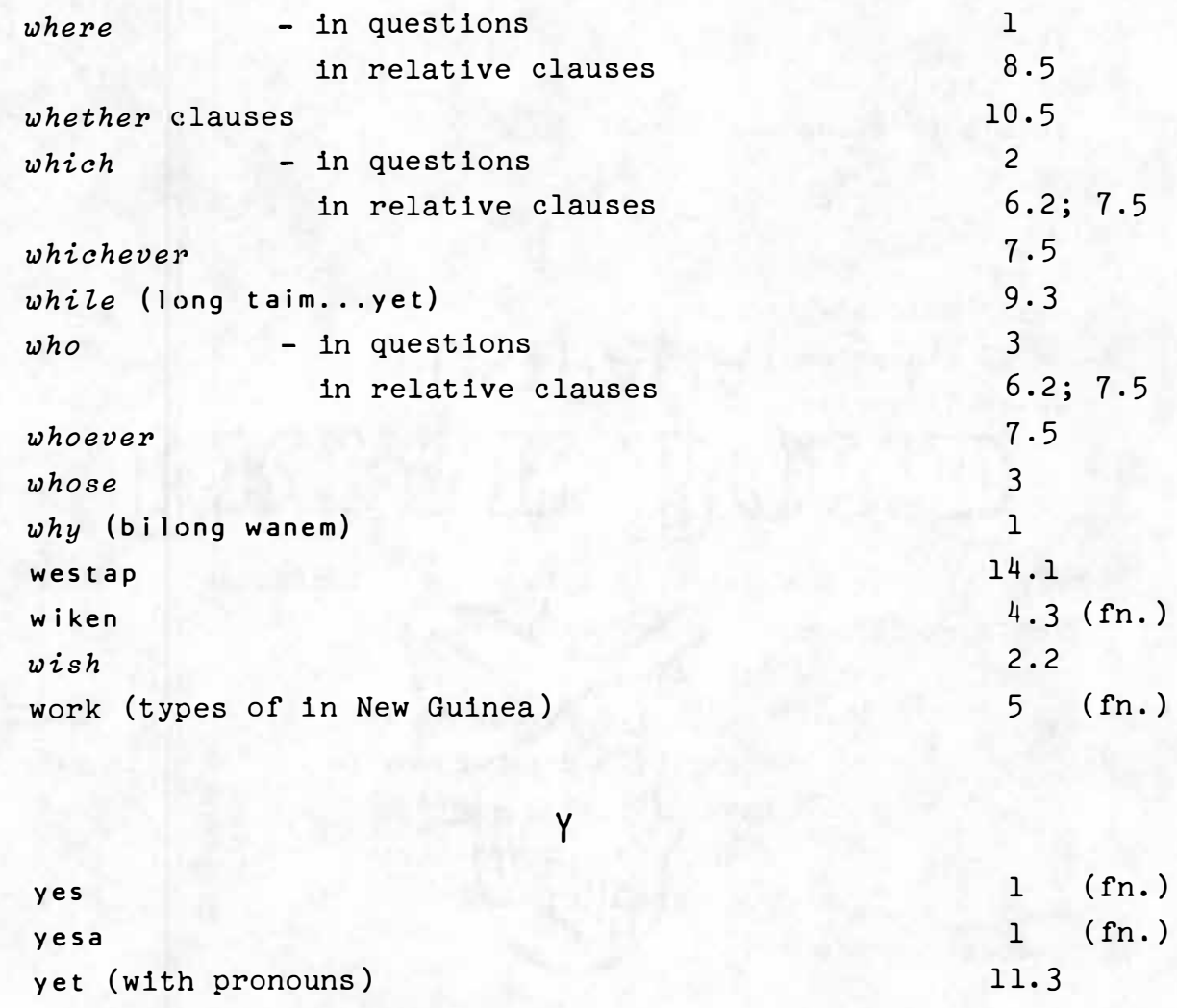




\section{A NEW GUINEA PIDGIN READING LIST}

1. History, Development and Use

Bell, H. L. (1971) "Language and the Army of Papua-New Guinea," Army Journal, No. 264 (May, 1971): 31-42.

Brash, E. (1971) "Tok Pilai, Tok Piksa na Tok Bokis," Kivung, $4(1): 12-21$.

Dutton, T. E. (1970) "Informal English in the Torres Straits." In W. S. Ramson (ed.) English Transported (Canberra: Australian National University Press) pp.137-60.

Gunther, J. (1969) "More English, More Teachers!" New Guinea, $4(2): 43-53$.

Hall, R. A. (Jr.) (1955) "'Neo-Melanesian' instead of Pidgin English," Modern Language Notes, 30:76.

(1955) "Pidgin English in the British Solomon Islands," Australian Quarterly, 27 (4): 68-74.

(1955) Hands of6 Pidgin English. (Sydney).

(1956) "Innovations in Melanesian Pidgin (Neo-Melanesian), Oceania, 26: 91-109.

Hull, B. (1968) "The Use of Pidgin in the House of Assembly," The Journal of the Papua and New Guinea Society, 2 (1): 22-5.

Hymes, D. (ed.) (1971) Pidginization and Creolization of Languages. (Cambridge University Press).

Laycock, D. (1969) "Pidgin's Progress," New Guinea, 4 (2): 8-15. (1970) "Development of New Guinea Pidgin." In Introduction to Materials in New Guinea Pidgin (Coastal and Lowlands). (Canberra: Pacific Linguistics, Series D, No. 5, The Australian National University).

(1970) "Pidgin English in New Guinea." In W. S. Ramson (ed.) English Transported. (Canberra: Australian National University Press) pp.102-23.

Salisbury, R. F. (1967) "Pidgin's Respectable Past," New Guinea, $2(2): 44-8$.

Smith, G. (1969) "An Educational Balance Sheet," New Guinea, 4 (2) : 16-29.

Wurm, S. A. (1966) "Pidgin--a National Language," New Guinea, 7: 49-54.

(1966-67) "Papua-New Guinea Nationhood: the Problem of a National Language," The Journal of the Papua and New Guinea Society, 1 (1): 7-19.

(1969) "English, Pidgin and What Else?" New Guinea, 4 (2): 30-42.

\section{Structure}

Hooley, B. A. (1963) "Transformations in Neo-Melanesian," Oceania, 33: 116-27. 
Laycock, D. (1970) Materials in New Guinea Pidgin lCoastal and Lowlands). (Canberra: Pacific Linguistics, Series D, No. 5, The Australian National University). [\$2.50]

Litteral, R. (1969) A Programmed Course in New Guinea Pidgin. (Brisbane: Jacaranda Press) With tapes. [\$4.00 +\$10.00?]

Mihalic, F. (1971) The Jacaranda Dictionary and Grammar of Melanesian Pidgin. (Brisbane: Jacaranda Press). [\$6.50]

Murphy, J. J. (1966) The Book of Pidgin English (rev. ed.). (Brisbane: Smith and Patterson).

Thomas, H. S. (1969) Learning Pidgin. (Sydney: The Australian Broadcasting Commission). [\$0.50]

Wurm, S. A. (1971) New Guinea Highlands Pidgin: Course Materials. (Canberra: Pacific Linguistics, Series D, No. 3, The Australian National University). [\$3.50]

3. Reading Materials

"Wantok": A fortnightly Pidgin newspaper published by Wantok Publications Inc., P.O. Box 298, Wewak, Papua New Guinea. [10\$ per copy locally]

"Nius Bilong Yumi": A fortnightly news-sheet published by the Department of Information and Extension Services, Papua New Guinea. [Free but there is a waiting list.]

Nupela Testamen. (Canberra: British and Foreign Bible Society in Australia, 1969). [\$2.00]

Numerous short (about 50pp. 20-30\$ each) booklets on various topics published by Kristen Press, Madang, Papua New Guinea. [Pricelist on application.]

Raunabaut: A bi-monthly journal produced by Bougainville Copper, Melbourne.

Various songs, poems, plays and literary items in Papua Pocket Poets Series and Kovave: A Journal of New Guinea Literature available at University of Papua and New Guinea Bookshop, Waigani, Papua New Guinea.

Several LUKSAVE (abbreviations of longer research publications) avallable from The New Guinea Research Unit, P.0. Box 1238, Boroko, Papua New Guinea. [25\$ each]

News and items of interest broadcast over the $A B C$ and District (local) Radio Stations throughout Papua New Guinea. 